\title{
Baseline and Projected Future Carbon Storage and Carbon Fluxes in Ecosystems of Hawai'i
}

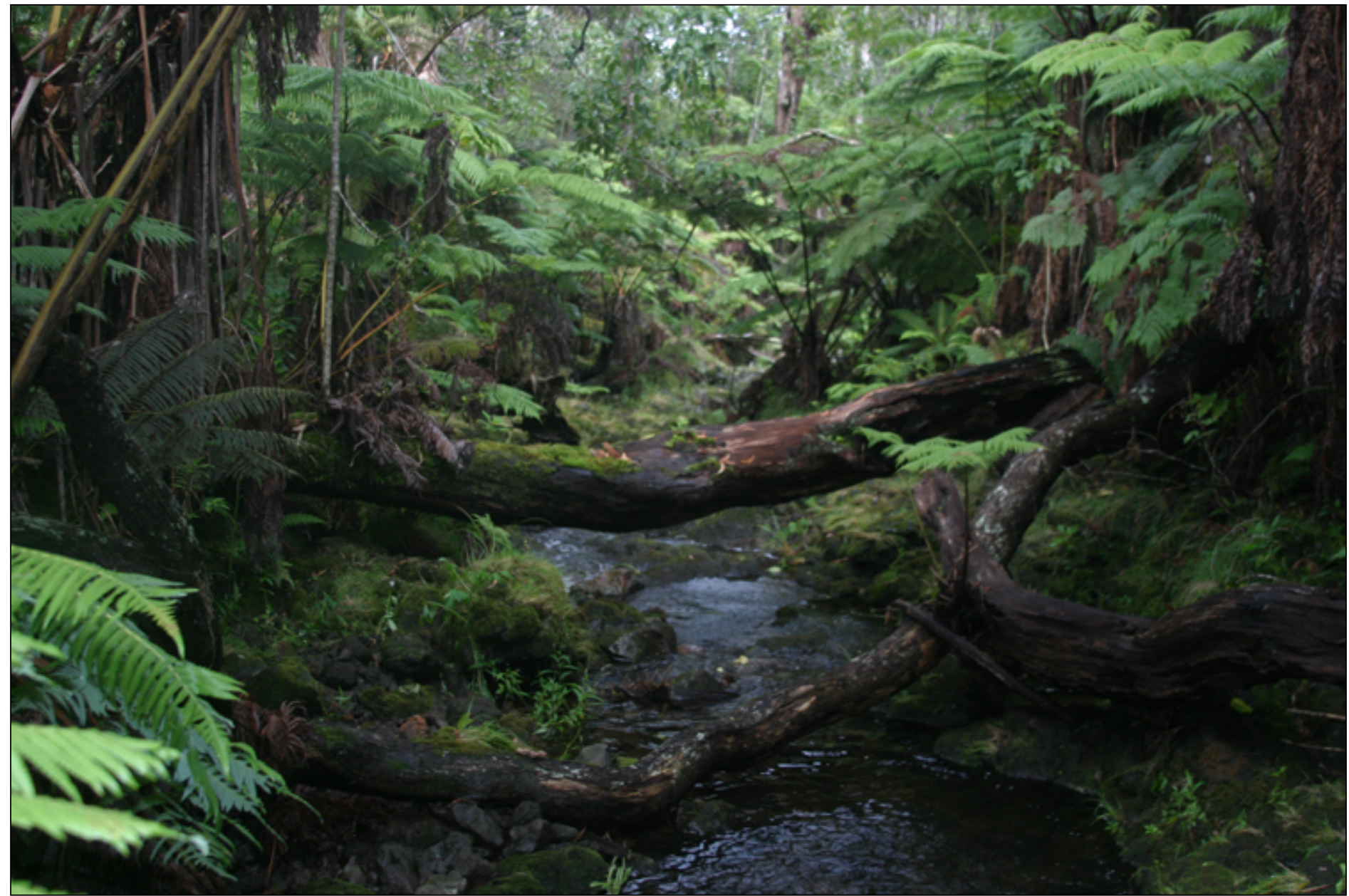

Professional Paper 1834 



\section{Baseline and Projected Future Carbon Storage and Carbon Fluxes in Ecosystems of Hawai'i}

Edited by Paul C. Selmants, Christian P. Giardina, James D. Jacobi, and Zhiliang Zhu

Professional Paper 1834 


\title{
U.S. Department of the Interior \\ RYAN K. ZINKE, Secretary
}

\author{
U.S. Geological Survey \\ William H. Werkheiser, Acting Director
}

U.S. Geological Survey, Reston, Virginia: 2017

For more information on the USGS—-the Federal source for science about the Earth, its natural and living resources, natural hazards, and the environment-visit https://www.usgs.gov or call 1-888-ASK-USGS

(1-888-275-8747).

For an overview of USGS information products, including maps, imagery, and publications,

visit https://store.usgs.gov.

Any use of trade, firm, or product names is for descriptive purposes only and does not imply endorsement by the U.S. Government.

Although this information product, for the most part, is in the public domain, it also may contain copyrighted materials as noted in the text. Permission to reproduce copyrighted items must be secured from the copyright owner.

Suggested citation:

Selmants, P.C., Giardina, C.P., Jacobi, J.D., and Zhu, Zhiliang, eds., 2017, Baseline and projected future carbon storage and carbon fluxes in ecosystems of Hawai'i: U.S. Geological Survey Professional Paper 1834, 134 p., https://doi.org/10.3133/pp1834.

ISSN 2330-7102 (online) 


\section{Acknowledgments}

Bradley Reed (U.S. Geological Survey) assisted with the initial organization and structure of this report. Paul Berkowitz (U.S. Geological Survey) provided spatial data support for multiple chapters. Thanks to Amy Koch (USDA Natural Resources Conservation Service) for assistance with gSSURGO soil carbon data, and to Tom Giambelluca (University of Hawaili at Mānoa),

Rebecca Ostertag (University of Hawai'i at Hilo), Qi Chen (University of Hawai'i at Mānoa), and Sarah Stackpoole (U.S. Geological Survey) for reviewing the chapters of this report. 



\section{Contents}

Executive Summary-Baseline and Projected Future Carbon Storage and Carbon Fluxes in Ecosystems of Hawai'i.

By Paul C. Selmants, Christian P. Giardina, James D. Jacobi, Lucas B. Fortini, R. Flint Hughes, Todd J. Hawbaker, Richard A. MacKenzie, Benjamin M. Sleeter, and Zhiliang Zhu

Chapter 1. Scope and Methodology.....

By Christian P. Giardina, Paul C. Selmants, and James D. Jacobi

Chapter 2. Baseline Land Cover.

By James D. Jacobi, Jonathan P. Price, Lucas B. Fortini, Samuel M. Gon III, and Paul Berkowitz

Chapter 3. Projecting End-of-Century Shifts in the Spatial Pattern of Plant-Available Water Across Hawai'i i to Assess Implications to Vegetation Shifts

By Lucas B. Fortini, James D. Jacobi, and Jonathan P. Price

Chapter 4. Influence of Invasive Species on Carbon Storage in Hawai'i's Ecosystems 43

By R. Flint Hughes, Gregory P. Asner, Creighton M. Litton, Paul C. Selmants, Todd J. Hawbaker, James D. Jacobi, Christian P. Giardina, and Benjamin M. Sleeter

Chapter 5. Wildland Fires and Greenhouse Gas Emissions in Hawai' $i$. 57

By Todd J. Hawbaker, Clay Trauernicht, Stephen M. Howard, Creighton M. Litton, Christian P. Giardina, James D. Jacobi, Lucas B. Fortini, R. Flint Hughes,

Paul C. Selmants, and Zhiliang Zhu

Chapter 6. Baseline Carbon Storage and Carbon Fluxes in Terrestrial Ecosystems of Hawai' $i$.... 75 By Paul C. Selmants, Christian P. Giardina, Sinan Sousan, David E. Knapp, Heather L. Kimball, Todd J. Hawbaker, Alvaro Moreno, Jami Seirer, Steve W. Running, Tomoaki Miura, Rafael Bergstrom, R. Flint Hughes, Creighton M. Litton, and Gregory P. Asner

Chapter 7. Baseline and Projected Future Aquatic Carbon Fluxes to Nearshore Waters in Hawai'i.

By Richard A. MacKenzie, Ayron M. Strauch, Tracy N. Wiegner, Steven L. Colbert, Edward G. Stets, and Robert G. Streigl

Chapter 8. Projected Future Carbon Storage and Carbon Fluxes in Terrestrial Ecosystems of Hawai'i from Changes in Climate, Land Use, and Disturbance .. 107

By Benjamin M. Sleeter, Jinxun Liu, Colin J. Daniel, Todd J. Hawbaker, Tamara S. Wilson, Lucas B. Fortini, James D. Jacobi, Paul C. Selmants, Christian P. Giardina, Creighton M. Litton, and R. Flint Hughes

Chapter 9. Hawai'i Carbon Balance...... 129

By Paul C. Selmants, Christian P. Giardina, Benjamin M.Sleeter, Jinxun Liu, and Zhiliang Zhu 


\section{Conversion Factors}

\begin{tabular}{|c|c|c|}
\hline Multiply & By & To obtain \\
\hline \multicolumn{3}{|c|}{ Length } \\
\hline centimeter $(\mathrm{cm})$ & 0.3937 & inch (in.) \\
\hline millimeter $(\mathrm{mm})$ & 0.03937 & inch (in.) \\
\hline meter $(\mathrm{m})$ & 3.281 & foot $(\mathrm{ft})$ \\
\hline kilometer $(\mathrm{km})$ & 0.6214 & mile (mi) \\
\hline kilometer $(\mathrm{km})$ & 0.5400 & mile, nautical (nmi) \\
\hline meter $(\mathrm{m})$ & 1.094 & yard (yd) \\
\hline \multicolumn{3}{|c|}{ Area } \\
\hline square meter $\left(\mathrm{m}^{2}\right)$ & 0.0002471 & acre \\
\hline hectare (ha) & 2.471 & acre \\
\hline square kilometer $\left(\mathrm{km}^{2}\right)$ & 247.1 & acre \\
\hline square centimeter $\left(\mathrm{cm}^{2}\right)$ & 0.001076 & square foot $\left(\mathrm{ft}^{2}\right)$ \\
\hline square meter $\left(\mathrm{m}^{2}\right)$ & 10.76 & square foot $\left(\mathrm{ft}^{2}\right)$ \\
\hline square centimeter $\left(\mathrm{cm}^{2}\right)$ & 0.1550 & square inch $\left(\mathrm{ft}^{2}\right)$ \\
\hline hectare (ha) & 0.003861 & square mile $\left(\mathrm{mi}^{2}\right)$ \\
\hline square kilometer $\left(\mathrm{km}^{2}\right)$ & 0.3861 & square mile $\left(\mathrm{mi}^{2}\right)$ \\
\hline \multicolumn{3}{|c|}{ Volume } \\
\hline cubic meter $\left(\mathrm{m}^{3}\right)$ & 6.290 & barrel (petroleum, 1 barrel = 42 gal) \\
\hline liter $(\mathrm{L})$ & 33.81402 & ounce, fluid (fl. oz) \\
\hline liter $(\mathrm{L})$ & 2.113 & pint $(\mathrm{pt})$ \\
\hline liter $(\mathrm{L})$ & 1.057 & quart (qt) \\
\hline liter $(\mathrm{L})$ & 0.2642 & gallon (gal) \\
\hline cubic meter $\left(\mathrm{m}^{3}\right)$ & 264.2 & gallon (gal) \\
\hline cubic meter $\left(\mathrm{m}^{3}\right)$ & 0.0002642 & million gallons (Mgal) \\
\hline cubic centimeter $\left(\mathrm{cm}^{3}\right)$ & 0.06102 & cubic inch $\left(\right.$ in $\left.^{3}\right)$ \\
\hline cubic meter $\left(\mathrm{m}^{3}\right)$ & 35.31 & cubic foot $\left(\mathrm{ft}^{3}\right)$ \\
\hline cubic meter $\left(\mathrm{m}^{3}\right)$ & 1.308 & cubic yard $\left(\mathrm{yd}^{3}\right)$ \\
\hline cubic meter $\left(\mathrm{m}^{3}\right)$ & 0.0008107 & acre-foot (acre-ft) \\
\hline cubic meter $\left(\mathrm{m}^{3}\right)$ & 6.290 & barrel (petroleum, 1 barrel = 42 gal) \\
\hline \multicolumn{3}{|c|}{ Flow rate } \\
\hline cubic meter per day $\left(\mathrm{m}^{3} / \mathrm{d}\right)$ & 35.31 & cubic foot per day $\left(\mathrm{ft}^{3} / \mathrm{d}\right)$ \\
\hline cubic meter per day $\left(\mathrm{m}^{3} / \mathrm{d}\right)$ & 264.2 & gallon per day (gal/d) \\
\hline \multicolumn{3}{|c|}{ Mass } \\
\hline $\operatorname{gram}(\mathrm{g})$ & 0.03527 & ounce, avoirdupois (oz) \\
\hline kilogram (kg) & 2.205 & pound avoirdupois (lb) \\
\hline metric ton $(\mathrm{t})$ & 1.102 & ton, short $[2,000 \mathrm{lb}]$ \\
\hline metric ton $(\mathrm{t})$ & 0.9842 & ton, long $[2,240 \mathrm{lb}]$ \\
\hline
\end{tabular}




\section{Datum and Supplemental Information}

Horizontal coordinate information is referenced to the North American Datum of 1983 (NAD 83).

Temperature in degrees Celsius $\left({ }^{\circ} \mathrm{C}\right)$ may be converted to degrees Fahrenheit $\left({ }^{\circ} \mathrm{F}\right)$ as

$$
{ }^{\circ} \mathrm{F}=\left(1.8 \times{ }^{\circ} \mathrm{C}\right)+32
$$

Pixel resolution in spatial datasets follows the format " $n$-meter resolution," where $n$ is a numerical value corresponding to the length of one side of a square pixel. A square pixel with length $n$ for each side covers an area of $n$ meters $\times n$ meters.

Conversion of Megagrams, Gigagrams, Teragrams, and Petagrams to Metric Tons

$$
\begin{array}{lll}
1 \text { megagram }(\mathrm{Mg}) & =1 \text { million grams }\left(10^{6} \mathrm{~g}\right) & =1 \text { metric ton }(\mathrm{t}) \\
1 \text { gigagram }(\mathrm{Gg}) & =1 \text { billion grams }\left(10^{9} \mathrm{~g}\right) & =1,000 \text { metric tons } \\
1 \text { teragram }(\mathrm{Tg}) & =1 \text { trillion grams }\left(10^{12} \mathrm{~g}\right) & =1 \text { million metric tons }(\mathrm{Mt}) \\
1 \text { petagram }(\mathrm{Pg}) & =1 \text { quadrillion grams }\left(10^{15} \mathrm{~g}\right)=1 \text { illion metric tons }(\mathrm{Gt})
\end{array}
$$





\title{
Executive Summary-Baseline and Projected Future Carbon Storage and Carbon Fluxes in Ecosystems of Hawai'i
}

\author{
By Paul C. Selmants, ${ }^{1}$ Christian P. Giardina, ${ }^{2}$ James D. Jacobi, ${ }^{1}$ Lucas B. Fortini, ${ }^{1}$ R. Flint Hughes, ${ }^{2}$ Todd J. Hawbaker, ${ }^{1}$ \\ Richard A. MacKenzie, ${ }^{2}$ Benjamin M. Sleeter, ${ }^{1}$ and Zhiliang Zhu ${ }^{1}$
}

Hawai' $i$ is unique among the United States because of its tropical climate, geographic isolation, high rates of species endemism, and discontinuous landmass. The year-round warm, wet climate on the windward sides of islands and the high fertility of relatively young volcanically derived soils are ideal conditions for carbon input, storage, and sequestration in ecosystems of the main Hawaiian Islands. Over the last three decades, several plotand stand-level studies, conducted at the scale of tens to hundreds of square meters, have demonstrated the high carbon sequestration capacity of Hawaiian terrestrial ecosystems with a focus on soils, live biomass, and plant productivity. However, there have been relatively few studies conducted at landscape (hundreds to thousands of square meters) to islandwide scales examining the biotic and environmental controls on aboveground carbon density and no islandwide to statewide estimates of carbon fluxes and net carbon balance for ecosystems of the Hawaiian Islands. The goal of this report is to provide robust baseline estimates of carbon storage and flux across the Hawaiian Islands based on the best available data and to then use this baseline data as input to predict how carbon cycling and storage may respond to projected future changes in climate, land use, land cover, and disturbance.

Major components of the assessment include a new high-resolution land-cover map for the State of Hawai' $i$; projected future shifts in climatic zones owing to global warming; baseline estimates of carbon emissions from wildfire; comprehensive statewide estimates of current ecosystem carbon stocks in soils, live biomass, and detritus; comprehensive statewide estimates of current carbon fluxes from gross primary production (GPP) and ecosystem respiration $\left(R_{\mathrm{e}}\right)$; current and projected future stream- and groundwater carbon fluxes to nearshore waters; and statewide estimates of current and projected future net ecosystem carbon balance (NECB) based on projected changes in climate, wildfire, land use, and land cover. Major findings from the assessment are as follows:

Total carbon stored in terrestrial ecosystems across the seven main Hawaiian Islands (excluding $\mathrm{Ni}^{\text {‘ }}$ ihau) was

\footnotetext{
${ }^{1}$ U.S. Geological Survey.

${ }^{2}$ U.S. Department of Agriculture Forest Service.
}

estimated to be $258 \mathrm{TgC}$, of which 71 percent was soil organic carbon (SOC) to $1 \mathrm{~m}$ depth, 24 percent was live biomass (above and below ground), and 5 percent was dead biomass (a combination of litter and downed woody debris). Hawai' $i$ Island, the largest island in the Hawaiian archipelago, stored $136 \mathrm{TgC}$, which accounted for 58 percent of the total carbon storage in the State of Hawai' $i$, whereas the island of Kaua' $i$ had the highest carbon density (carbon storage per unit area), estimated as $23.5 \mathrm{kgC} / \mathrm{m}^{2}$.

Live-biomass carbon storage in native forests was estimated as $32 \mathrm{TgC}$, which was 51 percent of all carbon stored as live biomass $(63 \mathrm{TgC})$, followed by invaded forests $(21 \mathrm{TgC})$ and alien tree plantations $(6 \mathrm{TgC})$.

Between 2003 and 2014, GPP across the seven islands averaged $20.2 \mathrm{TgC} / \mathrm{yr}$, with Hawai' $i$ Island accounting for 55 percent of this flux $(11.2 \mathrm{TgC} / \mathrm{yr})$. The island of Kaua' $i$ had the highest mean annual GPP carbon flux density (GPP per unit land area) estimated at $1.85 \mathrm{kgC} / \mathrm{m}^{2}$.

Carbon lost to the atmosphere from wildfire emissions was estimated as $0.03 \mathrm{TgC} / \mathrm{yr}$, and carbon lost to nearshore waters from stream- and groundwater fluxes was estimated as $0.3 \mathrm{TgC} / \mathrm{yr}$ for the current baseline period, which was approximately 4 percent of statewide annual net primary production (NPP) of terrestrial ecosystems.

Terrestrial ecosystems of the seven main Hawaiian Islands sequestered an average of $0.34 \mathrm{TgC} / \mathrm{yr}$ during the baseline period, which was approximately 4 percent of statewide terrestrial NPP. Hawai' $i$ Island represented the largest carbon sink, sequestering $0.24 \mathrm{TgC} / \mathrm{yr}$ or 70 percent of total statewide carbon sequestration.

During the projected future period (2012-2061), carbon sequestration of terrestrial ecosystems of the State of Hawai' $i$ would decrease by more than 30 percent (from 0.34 to $0.22 \mathrm{TgC} / \mathrm{yr}$ ) primarily because of a decrease in NPP and increased carbon losses from land-use and land-cover change, as well as increased aquatic carbon-leaching losses to nearshore waters.

The State of Hawai' $i$ was projected to remain a net carbon sink in 2061, primarily because of carbon sequestration in terrestrial ecosystems on Hawai'i Island. However, predicted landuse changes on the islands of Kaua' $i$ and $\mathrm{O}^{\prime}$ ahu were projected to convert these islands from net carbon sinks to net carbon sources to the atmosphere by 2061 . 


\section{Limitations of the Assessment Report}

There are several known limitations of the assessment report. First, only a single climate projection scenario was used to project moisture-zone shifts in Fortini and others (this volume, chap. 3). Future analyses would benefit from multiple climate projection scenarios. Second, estimates of ecosystem respiration in Selmants and others (this volume, chap. 6) were based on the relationship between estimates of GPP and $R_{\mathrm{e}}$ from eddy flux towers, none of which were located in the Hawaiian Islands, and these estimates agreed poorly with model output from Sleeter and others (this volume, chap. 8), yielding high uncertainty for this large and important pathway of ecosystem carbon loss to the atmosphere and also affecting estimates of net ecosystem production (NEP) and NECB.

With regard to future assessments, the technical needs for reduction of uncertainties present in this assessment will require enhancements in observation systems and modeling research.
Key enhancements in observation systems include inventory measurements of shrubland and grassland aboveground biomass and root-to-shoot ratios, direct measurements of streamflow and carbon concentration of ephemeral streams on the leeward sides of the seven main Hawaiian Islands, and the incorporation of currently unpublished data from eddy flux towers in the State of Hawai'i (Thomas Giambelluca, University of Hawai'i at Mānoa) as well as the establishment of new eddy flux towers to directly assess the balance of $\mathrm{CO}_{2}$ flux between terrestrial ecosystems and the atmosphere. Key enhancements in modeling research include the development of an ensemble approach to ecosystem modeling and the development and incorporation of multiple climate-change and land-management scenarios that include different intensities of agricultural activities, conservation, ecological restoration, invasive species management, and wildfire suppression and prevention efforts. Although there are substantial uncertainties in our analyses, the analyses themselves represent state-of-the-art science, and this assessment provides information for priorities in reducing uncertainties that should improve future assessments. 
Baseline and Projected Future Carbon Storage and Carbon Fluxes in Ecosystems of Hawai' $i$

Editors: Paul C. Selmants, Christian P. Giardina, James D. Jacobi, and Zhiliang Zhu

U.S. Geological Survey Professional Paper 1834, 2017

\title{
Chapter 1. Scope and Methodology
}

\author{
By Christian P. Giardina, ${ }^{1}$ Paul C. Selmants, ${ }^{2}$ and James D. Jacobi ${ }^{2}$
}

\subsection{Scope and General Methodology of the Assessment}

This is the fifth regional report produced by the U.S. Geological Survey (USGS) as part of the national LandCarbon program (https://www2.usgs.gov/climate_landuse/land carbon/). As with prior assessments (Great Plains, Eastern, Western, and Alaska; see, for example, Zhu and others, 2012), this assessment focuses on using best available data to quantify current and future carbon stocks and fluxes required to understand trajectories for carbon sequestration in the main Hawaiian Islands (fig. 1.1). To this end, this report considers (1) carbon stored in soils, living aboveground and belowground biomass carbon, detrital carbon in surface litter and coarse woody debris, and (2) carbon entering Hawai' $i$ as gross primary production (GPP) and net primary production (NPP) and carbon exported to the nearshore by streams and submarine groundwater discharge (fig. 1.2). This report provides a "wallto-wall" assessment of carbon storage and flux, as well as projected future storage and flux for the seven main Hawaiian islands of Kaua'i, O'ahu, Moloka'i, Lāna'i, Kaho'olawe, Maui, and Hawai' $\mathrm{i}$, excluding the island of $\mathrm{Ni}^{\prime}$ 'ihau, which is privately owned. Because there is no public access to $\mathrm{Ni}^{\text {' }}$ ihau, few data for the island could be used to build carbon maps. The total area covered by this report is 16,587 square kilometers $\left(\mathrm{km}^{2}\right)$, distributed across islands in decreasing-size order: Hawai' $\mathrm{i}$ Island $\left(10,432 \mathrm{~km}^{2}\right)$, Maui $\left(1,884 \mathrm{~km}^{2}\right)$, O'ahu $\left(1,545 \mathrm{~km}^{2}\right)$, Kaua'i $\left(1,430 \mathrm{~km}^{2}\right)$, Moloka'i $\left(637 \mathrm{~km}^{2}\right)$, Lāna'i $\left(364 \mathrm{~km}^{2}\right)$, and the uninhabited Kaho'olawe $\left(115 \mathrm{~km}^{2}\right)$. Ni'ihau is $180 \mathrm{~km}^{2}$ and makes up approximately 1 percent of the State of Hawai'i's total land area, and so exclusion from the report will have negligible effects on the overall assessment.

The Energy Independence and Security Act of 2007 (EISA; 42 USC 17001) requires that current and future stores and fluxes (carbon sequestration) be assessed for all 50 states, and it identified the U.S. Department of the Interior as the lead agency charged with developing and implementing a robust methodology with the goal of quantifying (1) the amount of carbon stored in ecosystems, (2) the capacity of ecosystems to sequester carbon, and (3) the mass balance of greenhouse gas (GHG) fluxes into and out of regions of interest. The carbon

${ }^{1}$ U.S. Department of Agriculture Forest Service.

${ }^{2}$ U.S. Geological Survey. assessment for Hawai ${ }^{i}$ (CAH) seeks to realize the mandate of the EISA to advance the state of knowledge on carbon storage and flux for the Hawaiian archipelago (fig. 1.3). Further, this report considers the effects of climate change and major disturbances (fire, land-use, nonnative invasions) on carbon cycling. Because of data limitations, we diverge from prior reports and consider only fluxes of carbon dioxide $\left(\mathrm{CO}_{2}\right)$, dissolved inorganic carbon (DIC), and dissolved organic carbon (DOC). We do not consider volatile organic carbon (VOC) emissions from vegetation or consider other trace gases (for example, $\mathrm{CH}_{4}, \mathrm{~N}_{2} \mathrm{O}$ ) that contribute to the global warming potential budget for the State of Hawai' $i$.

We relied on previous wall-to-wall mapping efforts to identify all major vegetation types in Hawai' $i$, including forests, shrublands, and grasslands distinguished according to moisture regime (dry, mesic, and wet) and ecological condition (native dominated, mostly native, and mostly nonnative). Further, we consider agricultural, urban, and aquatic systems. Details (definition, area, and distribution) for the initial vegetation and land-use and land-cover (LULC) types considered in this report are addressed in Jacobi and others (this volume, chap. 2), which relies on previous work merging a LandFIRE-enhanced Hawai' i-specific GAP product with the National Land Cover Database (NLCD; Vogelmann and others, 2001; Homer and others, 2007). The hybrid LULC product is derived from wallto-wall LANDSAT-based remote-sensing datasets, on-theground mapping, pictometry (Jacobi and others, this volume, chap. 2), and professional opinion. Consequently, with the exception of the Island of $\mathrm{Ni}^{\text {' }} \mathrm{ihau}$, this report provides spatially comprehensive data products.

As required by the LandCarbon program and the EISA, this assessment provides both current baseline and projected future carbon storage and flux estimates with the goal of providing both the science community and policy makers an unprecedented level of understanding of the carbonsequestration capacity of Hawaiian ecosystems. These data are essential for understanding the realistic options for carbon sequestration at the whole-state level. Here we use the term "baseline" to mean current anticipated carbon storage or flux derived from best available information, which in general was sufficient to provide moderately robust estimates to policy makers and scientists. Data used to determine baseline conditions reflect different time scales as data were collected during varying sampling campaigns during the past century; specifically, biome maps were created with vegetation data 


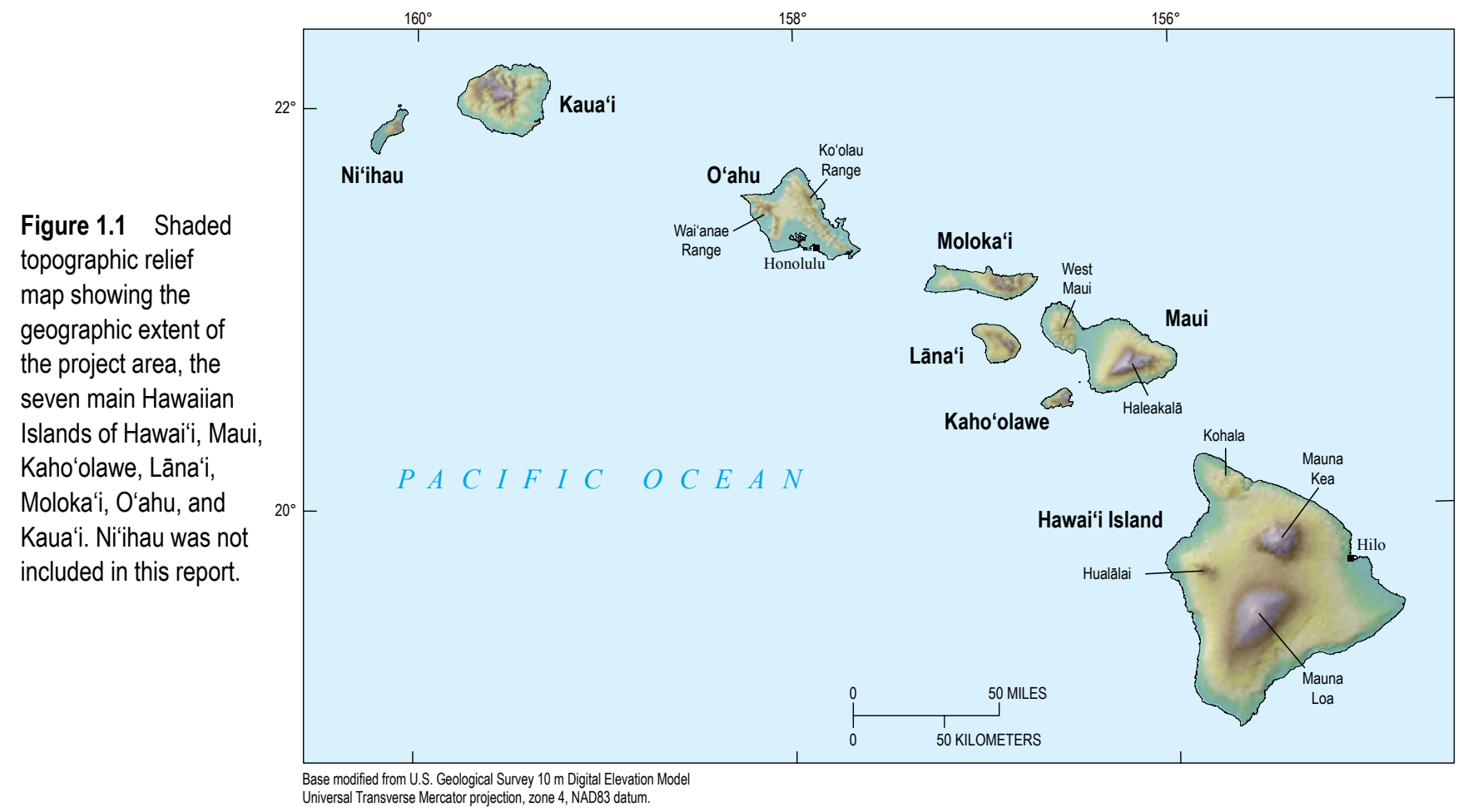

collected between 2000 and 2012; LULC data were derived from remote-sensing data collected in 2005; wildland-fire data were collected between 1904 and 2011; aboveground (and so belowground) biomass data reflect complex datasets collected in 2008 and 2009; soil-carbon data were based on the U.S. Department of Agriculture (USDA) Natural Resources Conservation Service (NRCS) excavations conducted during the past 50 years; GPP, NPP, and ecosystem-respiration data were modeled from data collected between 2004 and 2013; and data on carbon export in streams are based on gage data collected between 1972 and 2013. The datasets used for this assessment were provided by a diverse set of partners participating in the assessment including the USGS, USDA Forest Service and NRCS, Carnegie Institution for Science, University of Hawai ' $i$ at Mānoa, State of Hawai'i Division of Forestry and Wildlife, Nature Conservancy, and other organizations.

The carbon assessment for Hawai' $i$ relied on a complete carbon budgeting approach (fig. 1.3) that included the following features: (1) land-use and land-cover types (Jacobi and others, this volume, chap. 2) and biome and LULC maps delineating current distributions of vegetation types (Fortini and others, this volume, chap. 3); (2) modeled aboveground biomass for shrubs and grasslands, constructed and validated with biomass plots for these ecosystems types (Hawbaker and others, this volume, chap. 5); (3) remote-sensing-based quantification of aboveground biomass for forests, constructed with plane-based light detection and ranging (lidar) estimates of aboveground biomass and validated with plot data from USDA Forest Service Forest Inventory and Analysis (FIA) plots across the State of Hawai'i (Selmants and others, this volume, chap. 6); (4) modeled estimates of belowground live biomass based on generalized allometric equations linking aboveground and belowground biomass (Hawbaker and others, this volume, chap. 5); (5) MODIS-derived estimates of GPP and NPP and statistically determined relationships between GPP and ecosystem respiration to estimate net ecosystem production (NEP) (Selmants and others, this volume, chap. 6); (6) publicly available USDA NRCS mineral soil-carbon data; (7) spatially and temporally explicit carbon storage and GHG flux estimates (Selmants and others, this volume, chap. 6); and (8) streamgauge-based modeling of inorganic and organic carbon export by stream and groundwater discharge (MacKenzie and others, this volume, chap. 7). These data sources and modeling yielded a spatially extensive ( 99 percent of total land area for the State of Hawai'i) estimate of current carbon storage in Hawai'i's grassland, shrubland, and forest land base.

The carbon assessment relied on the above baseline data for carbon storage and future projected vegetation (Fortini and others, this volume, chap. 3) to identify current (Selmants and others, this volume, chap. 6) and potential future carbon storage and flux (Sleeter and others, this volume, chap. 8, and Selmants and others, this volume, chap. 9). Specifically, estimates of current carbon storage were paired with projected change in biome coverage for the years 2090-2100, which in turn was based on dynamical downscaling of global circulation models (1-3-km² resolution for Hawai' $i$ depending on island size). Projected biome maps were based on (1) modeling biome extent from projected climate variables of temperature and precipitation, where models are constructed from relationships between current climate and current modeled maps of biomes validated against current maps of actual biome type (Fortini and others, this volume, chap. 3); (2) Intergovernmental Panel on Climate Change (IPCC) Special Report on Emission Scenarios of climate and land use (Sleeter and others, this volume, 
chap. 8); and (3) state and transition-model-based estimates of carbon storage and flux under new configurations of biome and ecological condition (native dominated, mostly native, and mostly nonnative), where biome-specific and ecologicalcondition-specific carbon characteristics were carried forward and adjusted using map projections for the new distribution of biome type and ecological condition (Sleeter and others, this volume, chap. 8).

Several important caveats should be considered when interpreting projections from this assessment. Although current estimates are based on best available information required to quantify the carbon storage and flux, assessments of potential future carbon storage and flux under future climate and LULC are speculative as even the best projections for future climate and LULC in Hawai' $i$ are uncertain, particularly for future rainfall and LULC. Critically, this assessment does not construct global warming potential budgets that require a complete accounting of all GHGs and associated residence times in the atmosphere as well as cradle-to-grave (onsite and offsite sequestration) GHG analyses. Projected land-use changes are simply those projected by global-scale modeling of LULC, and so do not include careful local vetting. Further, projected future vegetation changes were derived entirely from dynamically downscaled climate data, which, as mentioned, carry important uncertainties, especially with respect to precipitation - an important driver of dry, mesic, and wet vegetation-type distributions. In addition, vegetation dynamics from succession or climate change were not modeled for the assessment. Nonetheless, this assessment represents a sophisticated integration of ground-based observations, planeand satellite-based remote sensing, and vegetation and climate numerical modeling, and so it provides an enormously improved carbon inventory compared to previous efforts for the region or compared to that which could be achieved relying solely on numerical modeling. We also examined the potential effects of fire on carbon emissions under current and projected future conditions for five of the seven main Hawaiian Islands (Hawbaker and others, this volume, chap. 5), and this work relied on (1) baseline carbon storage data (Selmants and others, this volume, chap. 6), and (2) inventoried and remotely sensed area burned (Trauernicht and others, 2015). Ecosystem disturbances considered by this report also included plant invasions. We do not consider, however, insect and disease outbreaks, hurricanes and other severe wind events, individual tree falls, or larger scale cohort senescence events of unknown cause.

The assessment is organized by biome (dry, mesic, and wet forest, shrubland, and grassland), by ecological condition (native dominated, mixed native and nonnative, mostly nonnative or heavily disturbed, and barren), and by major island. The terms stock or storage refer to the total amount of organic carbon contained by a reservoir of interest (for example, soil, living biomass, coarse woody debris), whereas flux refers both to $\mathrm{CO}_{2}$ uptake by ecosystems of Hawai' $i$ and to $\mathrm{CO}_{2}$ emissions to the atmosphere.

We relied on the following units of measurement for this report. Teragrams or petagrams of carbon $(\mathrm{TgC}$ or $\mathrm{PgC})$ are used for estimates of storage at the scale of the State of Hawai' $i$,
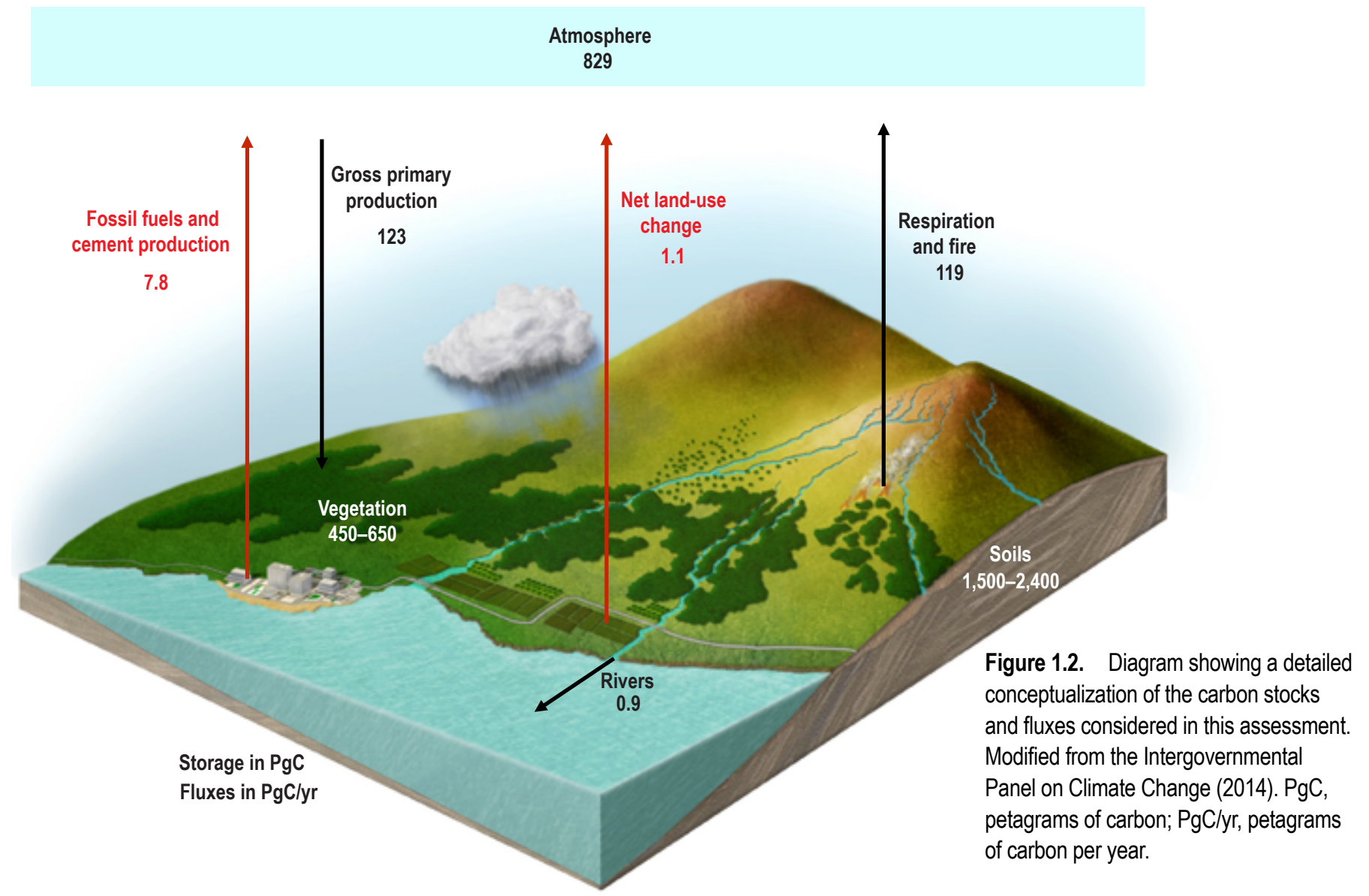


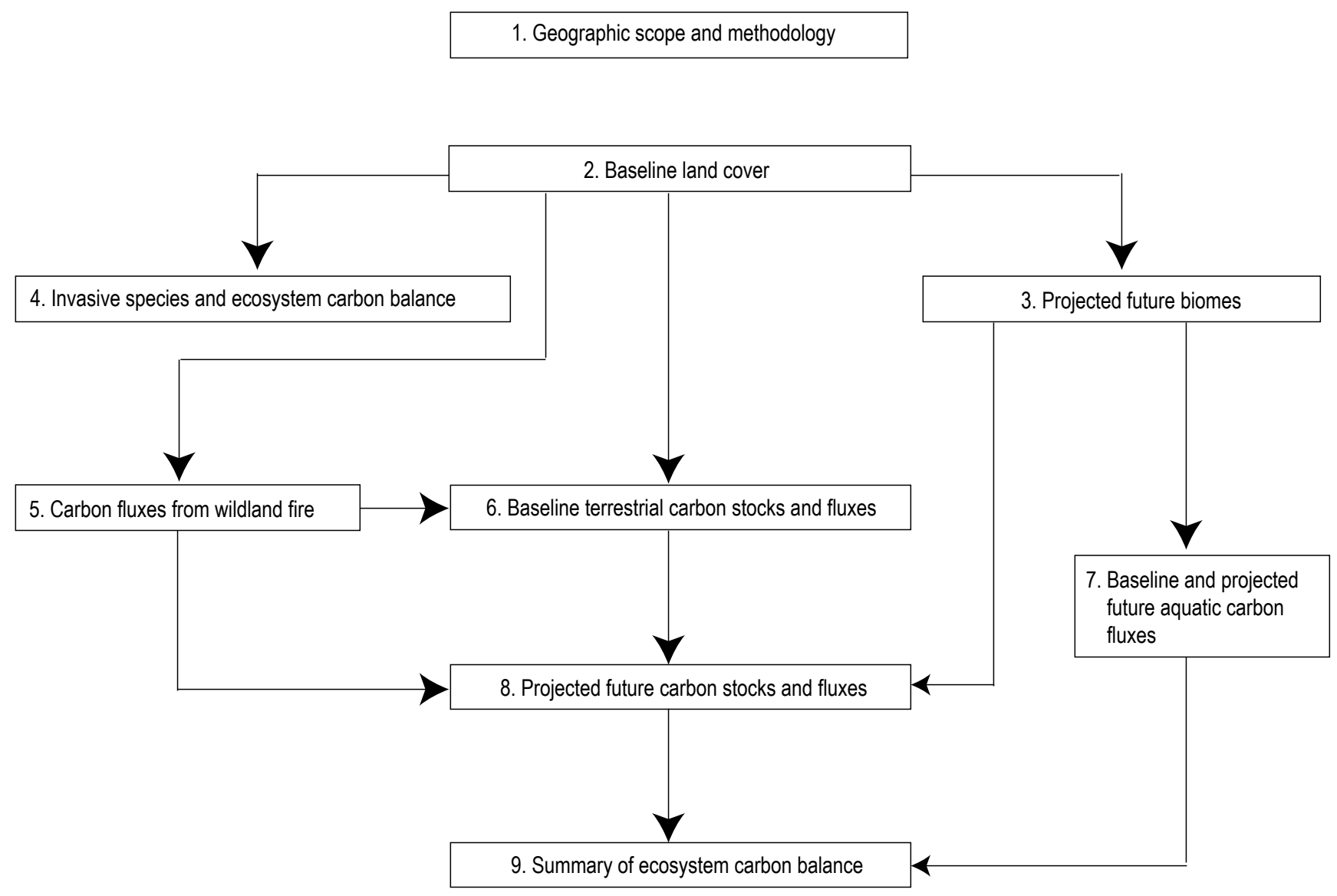

Figure 1.3. Diagram showing chapter flow of the Assessment.

whereas teragrams or petagrams of carbon per year $(\mathrm{TgC} / \mathrm{yr}$ or $\mathrm{PgC} / \mathrm{yr}$ ) are used for fluxes when reporting the total amount of carbon gained or released at this scale. The state-level balance of both losses and gains is called regional carbon balance (RCB). At the scale of a stand, carbon stock per unit of area is given in kilograms of carbon per square meter $\left(\mathrm{kgC} / \mathrm{m}^{2}\right)$ and carbon flux per unit of area (GPP, NPP, ecosystem respiration) is given in kilograms of carbon per square meter per year $(\mathrm{kgC} /$ $\mathrm{m}^{2} / \mathrm{yr}$ ). We identify the balance of carbon gain and carbon losses at the stand level (NEP), commonly viewed as NPP minus heterotrophic respiration $\left(R_{\mathrm{h}}\right)$. The transport of DIC and DOC by stream discharge is reported in teragrams of carbon per year. Unless otherwise noted, and following convention from previous reports (Zhu and others, 2012), fluxes are all listed as positive numbers, except in balance calculations, where we use the terrestrial ecosystem science convention of listing uptake of $\mathrm{CO}_{2}$ by ecosystems as positive and losses to the atmosphere as negative. Below is a chapter-by-chapter description of work encompassed in this assessment.

\subsubsection{Chapter-by-Chapter Description}

Chapter 2 addresses all land-cover components of the Hawai' $i$ assessment. Jacobi and others created land-cover maps for the Hawai' $i$ assessment by building upon diverse existing land-use and land-cover map products for the main Hawaiian Islands. The required integration across map products necessarily involved an evaluation of individual mapped units with respect to both accuracy and relevance for the Hawai' $i$ assessment. For the former, high-resolution imagery was used to improve accuracy of the mapped units including 2-m-resolution WorldView 2 and sub-meter-resolution Pictometry Online imagery. For the latter, previous delineations were collapsed into a hierarchical classification scheme that includes 48 detailed units, 27 general units, 13 biome units, and 7 land-cover units. An important modification associated with this effort included the refined delineation of ecological condition or status of the various vegetation-cover types into four broad classes: native dominated, mixed native and nonnative dominated, nonnative dominated or disturbed, and barren. Again, WorldView 2 and Pictometry Online imagery were used to improve delineations.

Chapter 3 examines potential climate-related major biome shifts during the current to end-of-century assessment period. To do this, Fortini and others mapped 500-m-resolution climatically determined wet (mean annual precipitation minus potential evapotranspiration [MAP-PET] >1,661 mm), mesic (MAPPET between 0 and $1,661 \mathrm{~mm}$ ), and dry (MAP-PET $<0 \mathrm{~mm}$ ) moisture zones under current and modeled future climate. For the former, MAT and seasonality of rainfall shape suitability of 
all areas of the main Hawaiian Islands to a given moisture zone, whereas for the latter, dynamically downscaled climate data for the 2090-2100 period are used to project shifts in moisture zones. Current distributions are validated by randomly splitting baseline input data into training ( 80 percent) and evaluation (20 percent) sets. Finally, current and future moisture-zone projections were integrated into previous mapping of forest, shrubland, and grassland cover-type classifications (Jacobi and others, this volume, chap. 2) to delineate nine major biome classes (dry, mesic, and wet forest, shrubland, and grassland) and understand how these broad biome types change in response to a shift from current to projected future modeled climate.

Chapter $\mathbf{4}$ addresses the conceptual foundation for understanding how nonnative species invasion impacts carbon storage, flux, and sequestration. The assessment includes this chapter because invasive species exert a large influence on the composition, structure, function, and dynamics of Hawai'i's ecosystems, and so they influence the carbon storage, flux, and sequestration capacity of Hawai' i's ecosystems. Globally there is great uncertainty about the role of invasive species in the carbon balance of terrestrial ecosystems, with recent meta-analyses showing diverse responses depending on the functional type of the invader, the composition and functioning of the ecosystem being invaded, and the type of biome hosting these interactions (Qiu, 2015). In this chapter, Hughes and others address these questions by examining, in a case-study design, how primary groups of nonnative invasive species (nitrogen-fixing trees and shrubs, non-nitrogen-fixing trees and shrubs, and fire-prone grasses) enter into ecosystems and modify processes regulating carbon balance. Effects can be positive (as with some nitrogenfixing trees on young geological substrates), negative (as with invasion of dry-to-mesic forests by fire-prone grasses and shrubs), or neutral or uncertain (as with understory invasions in wet forests). Overall, an effort is made to establish a framework for understanding these effects based on the structural and functional characteristics of the invader, the native communities being invaded, and the biome.

Chapter 5 addresses the role of fire-related disturbances on ecosystem carbon balance for the main Hawaiian Islands. Dryto-mesic areas of Hawai' $i$, like many areas of the dry-to-mesic tropics, experienced extensive land clearing in the past century for ranching and agricultural land uses. In the second half of the last century, both agricultural and ranching industries declined, resulting in a buildup of fuels on undermanaged ranchlands and an invasion of fire-prone vegetation on former agricultural lands. As a result, large areas of Hawai' $i$ were converted from forests characterized by low flammability vegetation to highly flammable shrub and grass vegetation, such that today more than 25 percent of total land area in Hawaii is threatened by wildfire, a disturbance that impacts vegetation composition, ecosystem function, and carbon storage and sequestration. Hawbaker and others estimated the effects of fire on carbon storage and sequestration for the main Hawaiian islands by (1) synthesizing annual-area-burned information from ground-based fire history databases (Trauernicht and others, 2015) and two remotely sensed data sources - the Monitoring Trends in Burn Severity database and Landsat 7 (the latter being used to examine fire occurrences recorded in the Hawai' $i$ fire history database but not in the MTBS database); (2) characterizing burn-severity patterns; (3) assembling biomass load data from 419 plots at 204 different sites examined in 19 studies and linking the associated plot- or site-level data to vegetation-cover types; (4) estimating the annual percentage of land in each cover type that burns; and finally (5) incorporating all of these data into the First-Order Wildland Fire Effects Model (FOFEM) to estimate biomass consumption and carbon-related fire emissions. Because of data gaps, Ni'ihau, Lāna'i, and Kaho'olawe were excluded from analyses in this chapter.

Chapter 6 examines ecosystem carbon stocks and fluxes at stand to whole-island scales. To examine stocks, Selmants and others assembled aboveground biomass carbon data for forests from Asner and others (2016), litter and downed woody debris data for all ecosystems from Hawbaker and others (this volume, chap. 5), and soil carbon to 1-m depth or bedrock from the NRCS gridded Soil Survey Geographic (gSSURGO) database. Selmants and others calculated belowground live biomass using a simple exponential equation describing the general relationship between root and shoot biomass for forest plants (Mokany and others, 2006) and aboveground-to-belowground ratios for grasslands (0.73) and shrublands (1.45). The main flux of carbon into ecosystems of Hawai' $i$ is GPP, and this was determined from a Hawai' $\mathrm{i}$-specific, 0.5 -km-resolution MOD17 MODIS data product, refined from the global product by using the Jacobi and others (this volume, chap. 2) vegetation classification to assign carbon-use efficiencies to vegetation-cover types. Further, a local, high-resolution climate database (Fortini and others, this volume, chap. 3) was used to drive MOD17-modeled GPP estimates. Estimates of NPP were determined by applying Hawai' $i$-specific MOD17 assumed carbon-use efficiency coefficients to GPP estimates. Further, ecosystem respiration (heterotrophic plus autotrophic) was estimated from separate equations for forests, shrublands, and grasslands developed from published studies in order to estimate NEP for all islands.

Chapter 7 evaluates the role of freshwater transport of carbon into oceans, including both stream transport and submarine groundwater discharge. For the former, MacKenzie and others estimated the flux of carbon transported in freshwater perennial streams to nearshore areas on Hawai $i$, Maui, Moloka'i, O'ahu, and Kaua' $\mathrm{i}$ Islands. There are no perennial streams on Lāna'i and Kaho'olawe and so they were excluded from the analysis. Long-term data for discharge, $\mathrm{pH}$, temperature, alkalinity, and carbon (total inorganic, total organic, and particulate) from 16 gaged perennial streams from across Hawai $i$, as well as watershed characteristics such as drainage area, basin slope, soil permeability, and land-cover class distributions, were used to build the relationships needed to predict freshwater carbon inputs to the nearshore using the regression-based Load Estimator Model. These 16 streams were selected because for each stream, daily discharge data and a minimum of 12 sample collections over 3 years were available for water chemistry and quantity. The calibrated and validated model was used to estimate daily carbon flux for more 
than 400 ungaged Hawai' $i$ perennial streams with modeled mean flow data, estimated rainfall, and channel morphological measurements. Critically, this chapter did not examine ephemeral streams, which make up a large proportion of the total streams in Hawai' $i$. For the latter flux, MacKenzie and others used a hydrological budgeting approach to estimate submarine groundwater discharge for the main Hawaiian Islands and groundwater chemical data from wells to estimate inorganic and organic carbon fluxes.

Chapter 8 addresses how changing climate and land use or land cover will potentially impact future carbon storage and flux in the State of Hawai' $i$. To do this, Sleeter and others relied on the Land Use and Carbon Scenario Simulator (LUCAS), an integrated state-and-transition simulation stock-flow model that is linked to the Integrated Biosphere Simulator (IBIS), itself a carbon-flux simulator. The model structure allows for the entire state to be mapped to 1 of 189 condition states ( 3 moisture zones, 9 land-cover types, and 7 islands). LUCAS provides the ability to impose transitions on each cell, including rates of change to new condition states, with LUCAS tracking time since transition (defined as the set of changes that move a cell from one condition to another) or age of vegetation captured within a cell (the latter being important for understanding the effects of fire on carbon storage, for example). In theory, any cell type could transition into any other cell type, but transition probabilities are determined by regularly updated adjacency functions, protected area status, and the professional judgement of land managers and the coauthor team, which limits or even eliminates the likelihood of some transitions. Following initialization with data derived from the above chapters, these probabilities allow for changes in land use to be coupled to a stock-flow carbon submodel, which can track associated changes in ecosystem carbon storage under the selected IPCC "business as usual" scenario. To enhance the level of detail achieved by LUCAS, each cell was modeled using IBIS to secure the following outputs: living wood, standing and downed deadwood, litter, and soil. Inputs to the IBIS model were NPP and GPP values reported in Selmants and others (this volume, chap. 6), with rates constrained by targeted amounts of living biomass that could not be exceeded. From this initial startup, the IBIS model was used to simulate seven flow paths for each cell including growth, litterfall, humification, mortality, deadfall, emissions, and leaching, each of which varies according to the cell type, vegetation type, surrounding environmental conditions, and transitions.

Chapter 9 synthesizes estimates of NPP and $R_{\mathrm{h}}$ from Selmants and others (this volume, chap. 6), aquatic carbon fluxes to nearshore waters from MacKenzie and others (this volume, chap. 7), and carbon emissions from fire from Hawbaker and others (this volume, chap. 5) to calculate net ecosystem carbon balance (NECB) and carbon sequestration potential for the baseline period. These synthesized estimates of NECB and carbon sequestration potential were then compared to NECB and carbon sequestration potential calculated using the first 5 years (2012-2016) of modeled simulation estimates of carbon fluxes by the IBIS ecosystem carbon submodel of the LUCAS model in Sleeter and others (this volume, chap. 8) to provide a range in baseline estimates. The overall trend in projected future ecosystem carbon balance and sequestration was examined by comparing islandwide and statewide estimates of mean annual NEP and NECB from the first 10 years of the modeled simulation (2011-2022) described in Sleeter and others (this volume, chap. 8) to islandwide and statewide estimates of mean annual NEP and NECB from the final 10 years of the modeled simulation (2051-2061). Implications, limitations, and uncertainties of the approach used to estimate statewide NECB and carbon sequestration are discussed, as are proposed mechanisms to improve future assessments in Hawai' $i$.

\subsection{References Cited}

Asner, G.P., Sousan, S., Knapp, D.E., Selmants, P.C., Martin, R.E., Hughes, R.F., and Giardina, C.P., 2016, Rapid forest carbon assessments of oceanic islands - a case study of the Hawaiian archipelago: Carbon Balance and Management, v. 11, no. 1, 13 p., available at http://dx.doi.org/10.1186/s13021-015-0043-4.

Homer, C., Dewitz, J., Fry, J., Coan, M., Hossain, N., Larson, C., Herold, N., McKerrow, A., VanDriel, J.N., and Wickham, J., 2007, Completion of the 2001 national land cover database for the conterminous United States: Photogrammatic Engineering and Remote Sensing, v. 73, no. 4, p. 337-341.

Mokany, K., Raison, R.J., and Prokushkin, A.S., 2006, Critical analysis of root : shoot ratios in terrestrial biomes: Global Change Biology, v. 12, no. 1, p. 84-96.

Qiu, J., 2015, A global synthesis of the effects of biological invasions on greenhouse gas emissions: Global Ecology and Biogeography, v. 24, no. 11, p. 1351-1362, available at http:// dx.doi.org/10.1111/geb.12360.

Trauernicht, C., Pickett, E., Giardina, C.P., Litton, C.M., Cordell, S., and Beavers, A., 2015, The contemporary scale and context of wildfire in Hawai'i: Pacific Science, v. 69, no. 4, p. 427-444, available at http://dx.doi.org/10.2984/69.4.1.

Vogelmann, J.E., Howard, S.M., Yang, L., Larson, C. R., Wylie, B. K., and Van Driel, J.N., 2001, Completion of the 1990's national land cover data set for the conterminous United States: Photogrammetric Engineering and Remote Sensing, v. 67, p. $650-662$.

Zhu, Z., Sleeter, B.M., Griffith, G.E., Stackpoole, S.M., Hawbaker, T.J., and Bergamaschi, B.A., 2012, An assessment of carbon sequestration in ecosystems of the Western United StatesScope, methodology, and geography, chap. 1 of Zhu, Z., and Reed, B.C., eds., Baseline and projected future carbon storage and greenhouse-gas fluxes in ecosystems of the Western United States: U.S. Geological Survey Professional Paper 1797, 12 p. (Also available at http://pubs.usgs.gov/pp/1797/.) 


\title{
Chapter 2. Baseline Land Cover
}

\author{
By James D. Jacobi, ${ }^{1}$ Jonathan P. Price, ${ }^{2}$ Lucas B. Fortini, ${ }^{1}$ Samuel M. Gon III, ${ }^{3}$ and Paul Berkowitz ${ }^{1}$
}

\subsection{Highlights}

- The land-cover map used for the carbon assessment of Hawai' $i$ was developed by integrating mapped components from several recent land-use and landcover maps and the mapped units were updated using very high resolution imagery, as needed.

- The resulting land-cover map has a hierarchical classification scheme that groups the mapped units into 48 detailed units, 27 general units, 13 biome units, and 7 major land-cover units.

- Although the detailed units more clearly depict the current vegetation composition of the area, we used the general units for calculating aboveground carbon stocks and the biome units were used as a basis for projecting vegetation distribution to 2100 based on climate change projections as reported in Fortini and others (this volume, chap. 3).

- An updated map depicting the current status of habitats on the main Hawaiian Islands was also produced. This habitat map identifies the vegetation in a given area as native dominated, a mix of native and alien species, heavily disturbed (agriculture, urban development) with few native species, or sparse to barren (recent lava flows or bare ground).

\subsection{Introduction}

The flora of the Hawaiian Islands is unique to the world, displaying some of the highest rates of species endemism for a major land area (Wagner and others, 1999; Ziegler, 2002). A primary factor leading to the development of the unique native flora and vegetation of Hawai' $i$ is the extreme isolation of this

\footnotetext{
${ }^{1}$ U.S. Geological Survey.

${ }^{2}$ University of Hawai' $i$ at Hilo.

${ }^{3}$ The Nature Conservancy of Hawai' $i$.
}

island archipelago; the closest continental area is North America, more than 3,200 km away (Juvik, 1998). The vast distances to other biological regions has dramatically restricted the number of species that have been able to successfully disperse across the Pacific Ocean and establish on these volcanic islands. The unique composition, structure, and species dynamics (such as disturbance history, species invasion, and succession) of the vegetation in Hawai $i$, in addition to land-use and land-cover changes, make this tropical island archipelago an essential addition to the overall carbon assessment of the United States.

The currently documented native Hawaiian flora is estimated to have resulted from just 258 successful colonizing species (Price and Wagner, 2011), which Juvik (1998) equates to species getting established in these islands at an average rate of one species every 98,000 years. Successfully colonizing species generally have small seeds that can be blown over the ocean by winds or dispersed by birds. Many of the ancestral species that ultimately became established in Hawai' $i$ were subsequently able to radiate into a myriad of new endemic species (Wagner and Funk, 1995). One other important result of this isolation was that only a few tree species could become naturally established in Hawai' $i$ and the resulting plant community composition and structure reflects the disharmonic nature of these few successfully colonizing taxa. This is clearly seen with 'ohi'a (Metrosideros polymorpha), which is the most abundant tree species in most native Hawaiian plant communities. 'Ohi'a is the dominant species forming the tree canopy in habitats that range from sea level to tree line, and it also dominates the vegetation from the wettest areas to very dry zones (Wagner and others, 1999; Mueller-Dombois and others, 2013). Perhaps the most remarkable feature of 'ohi'a is the fact that it displays most of the characteristics of a pioneer species and is able to quickly colonize new or disturbed sites through dispersal of its very small, wind-blown seeds. Additionally, 'ohi'a is relatively shade intolerant, another pioneer species characteristic. In most continental ecosystems, pioneer species are the first colonizers of a new or disturbed site but are eventually replaced by more typical climax species that are best adapted to getting established as secondary species in more mature habitats and are able to retain their dominance since they can regenerate even in dense understory shade conditions.

Within this backdrop of the disharmonic Hawaiian flora filtered by isolation, the vegetation on the main Hawaiian Islands is influenced by a combination of abiotic and biotic factors. 
Moisture availability, temperature, and substrate type and age are primary factors that determine the composition, structure, and distribution of plant species and communities across the archipelago (Pratt and Gon, 1998; Price and others, 2012).

However, human changes to the original landscape (for example, agriculture and development of urban areas) (Cuddihy and Stone, 1990; Warshauer, 1998), as well as impacts from a multitude of introduced invasive plant and animal species (Staples and Cowie, 2001), have dramatically altered the composition and distribution of many of the plant communities currently found in Hawai' $i$, particularly in lower elevation areas.

The northeast trade winds that blow in this region of the Pacific Ocean more than 75 percent of the time generally result in wet windward habitats and dry leeward habitats on all of the main Hawaiian Islands (Giambelluca and others, 2013). The only exceptions to this pattern are seen on the tall volcanoes on the islands of Hawai' $i$ and Maui, where the habitat becomes arid in the subalpine and alpine zones that lie above the trade-wind inversion layer (Giambelluca and others, 2013). Additionally the western (Kona) side of the Island of Hawai' $i$ is in the wind shadow of the two large volcanoes, Mauna Loa and Mauna Kea. As a result, the weather pattern in this area is not driven by the trade winds but by a daily convection-circulation system that results in a pattern of onshore winds during the daytime that allows for the development of much wetter conditions at mid-elevations, even in this leeward part of the island (Giambelluca and Schroeder, 1998). Price and others (2012) produced a map showing the distribution of seven moisture zones across the main Hawaiian Islands and it clearly depicts these two anomalous conditions (fig. 2.1).

Although there have been many maps produced that depict vegetation for the State of Hawai' $i$, only a few of these display land cover for all of the main Hawaiian Islands, and most of those that were created before the year 2000 have very generalized units or are somewhat inaccurate as a result of more recent landuse changes or poor resolution (both spatial and spectral) in the imagery that was used to produce the map. Some of the more detailed and accurate maps include the Hawai' $i$ GAP Analysis (HIGAP) land cover map (Gon and others, 2006), the NOAA C-CAP land cover map (NOAA National Ocean Service Coastal Services Center, 2012), and the more recently released Hawai ${ }^{i} i$ LANDFIRE EVT land cover map (U.S. Geological Survey, 2009). However, all of these maps as originally produced were not considered to be detailed enough or current enough, or they had other classification issues that would not allow them to be used as the primary base for the carbon assessment for Hawai $i \mathrm{i}(\mathrm{CAH})$.

For the CAH we integrated components from several of these previously mentioned land-use and land-cover mapping efforts and combined them into a single new land-cover map (CAH land cover) that was further updated using very high resolution imagery. The hierarchical classification system of the $\mathrm{CAH}$ land cover map allows for grouping the mapped units into different configurations, ranging from very detailed plant communities reflecting current conditions to very generalized major land-cover units and biomes that represent land use and potential vegetation zones, respectively. Additionally, we created an updated habitat status map based on the original version described in Price and others (2012). This map (CAH habitat status) depicts the distribution of plant communities that are (1) dominated by native species, (2) mixed native and alien species, (3) heavily disturbed areas with few native species, and (4) areas with less than 5 percent vegetation cover.

\subsection{Input Data and Methods}

The land-cover map used for the CAH was created by updating and combining spatial units from several previously produced maps using Esri ArcGIS ver. 10.2. Although the original maps were developed using imagery from various dates between 2000 and 2012, we considered them to represent "current" (about 2014) conditions. Base maps for this newly compiled CAH land-cover map included vegetation units and boundaries from the HIGAP land cover map (Gon and others, 2006), land-use units from the 2005 NOAA C-CAP map (NOAA National Ocean Service Coastal Services Center, 2012), the "bare" ( $<5$ percent vegetation cover) map unit from the Hawai' $i$ LANDFIRE map (Rollins, 2009; U.S. Geological Survey, 2009), and data on the distribution of managed tree plantations for the main Hawaiian Islands on both state lands (Yoshiko Akashi, Hawai'i Division of Forestry and Wildlife, unpublished data) and private lands (Nicholas Koch, Forest Solutions Inc., unpublished data). All spatial files were projected in UTM Zone 4 using the NAD83 datum. The HIGAP, NOAA C-CAP, and LANDFIRE maps were all based on LANDSAT TM imagery with 30 by $30 \mathrm{~m}\left(900 \mathrm{~m}^{2}\right)$ pixels. The tree-plantation maps were originally produced as polygon feature layers so they were converted to raster format and aligned to the same $30 \mathrm{~m}$ grid system that was used for the other maps and for the final $\mathrm{CAH}$ land-cover map.

Each land-use or land-cover data layer was reviewed for accuracy of its selected units by comparing the mapped units to more recent high-resolution WorldView 2 (WV2) digital satellite imagery collected by DigitalGlobe in 2010 ( $<2$-m pixel size; https://www.digitalglobe.com) and very high resolution imagery from Pictometry Online (POL; Pictometery International, 2014), which were also projected in UTM Zone 4 NAD 83. Where differences were found between the original mapped land-use and land-cover units and the high-resolution imagery, corrections were made to the original raster maps by reclassifying pixels to their correct values using the raster editing program Grid Editor developed by ARIS B.V. (2014). The HIGAP land cover layer needed the greatest amount of modification; these changes included (1) manually correcting misclassified pixels based on current high-resolution imagery, (2) combining similar or redundant mapping units with different names, (3) reclassifying some of the ambiguous HIGAP units (for example, "uncharacterized forest") into other mapped units, and (4) separating several of the HIGAP units (for example, "ohi'a forest", "koa forest") into subunits based on moisture zones described and mapped by Price and others (2012). The updated map layers were then combined into a single raster map (CAH land-cover), which also has 30-m pixel resolution, using the 


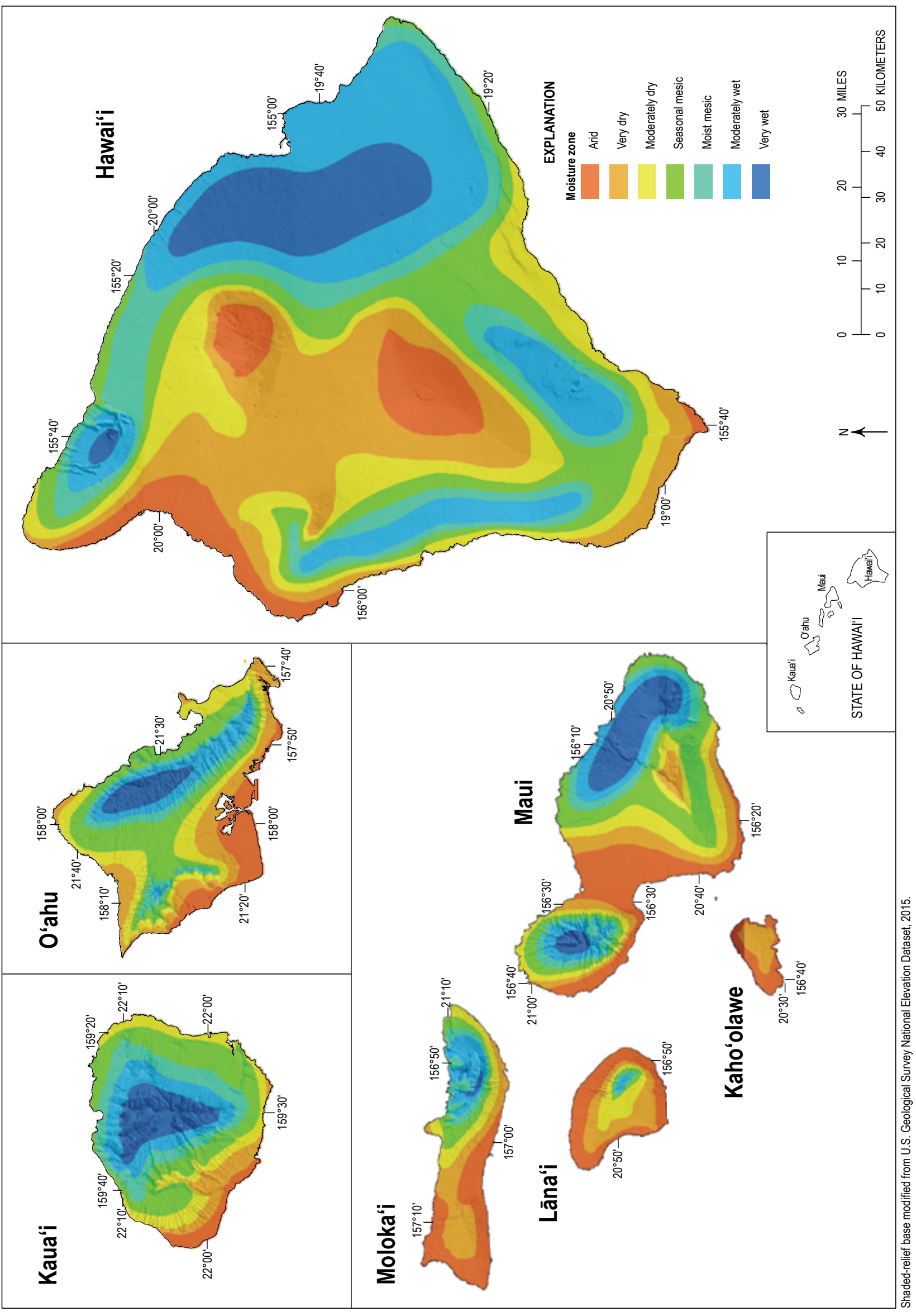

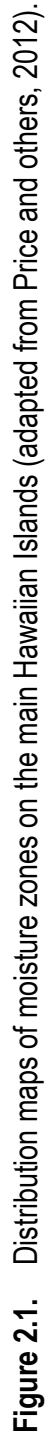


ArcGIS Mosaic tool. For this final map the updated HIGAP land cover map was used as the base map, with values from the NOAA C-CAP, LANDFIRE, and tree plantation maps replacing the HIGAP raster values that they overlaid.

The mapped units for the CAH land-cover map are linked to the alliance and association levels of the revised National Vegetation Classification (rUSNVC) which is based on the National Vegetation Classification Standard that was formally adopted by the Federal Geographic Data Committee (FGDC) in 2008 (FGDC, 2008). These units also correspond with NatureServe's Terrestrial Ecological Systems Classification (NatureServe, 2010, 2011). However, one major difference between the various $\mathrm{CAH}$ land-cover classification levels and the rUSNVC classification is that in the CAH land-cover map we did not separate the units into lowland, montane, and alpine units.

The CAH habitat status map was developed by modifying the original Habitat Quality map produced by Price and others (2012) using several more recent land-use and land-cover maps and imagery. This map was revised by combining mapped agriculture and land use, as well as the "bare" categories from the NOAA C-CAP 2005 map (NOAA National Ocean Service Coastal Services Center, 2012), and adding road corridors to the heavily disturbed category based on the Tiger Roads layer (U.S. Census Bureau, 2014). Additionally, corrections were made to this new version of the map by visually inspecting previously mapped units and comparing them to recent high-resolution imagery including WorldView 2 multi-spectral imagery and to very high resolution imagery obtained from Pictometry Online. Where needed, specific changes to pixels were reclassified using the ARIS GRID Editor. Because the CAH habitat status map was revised directly from a previous map, there are slight differences in the area calculations reported here for this map relative to areas reported for the CAH land-cover map, which was clipped by a different island polygon.

\subsection{Summary of Habitats and Land- Cover Units}

The CAH land-cover classification is hierarchical with 48 CAH Detailed land-cover units, which can be grouped into 27 $\mathrm{CAH}$ general land-cover units, $13 \mathrm{CAH}$ biome units, and $7 \mathrm{CAH}$ major land-cover units (Appendix 1). The CAH detailed landcover units generally correspond to the rUSNVC association level, the $\mathrm{CAH}$ general land-cover units correspond to the rUSNVC group level, and the CAH biome units correspond to the rUSNVC subclass level. Although the $\mathrm{CAH}$ detailed land-cover units more clearly depict the current vegetation of the area, we used the $\mathrm{CAH}$ general land-cover units for calculating aboveground carbon stocks (Hawbaker and others, this volume, chap. 5), and the $\mathrm{CAH}$ biome units were used as a starting point for projecting vegetation distribution in 2100 (see Fortini and others, this volume, chap. 3).

Based on our revised CAH habitat status map, more than 16 percent of the landscape on the main Hawaiian Islands has been heavily impacted by agriculture, urban development, and resort development (fig. 2.2; table 2.1). Approximately 31 percent of the islands are still dominated by native vegetation and 36 percent of the area has habitats that are somewhat disturbed, with a mix of native and alien plant species. The remaining area, 16 percent,

Table 2.1. Summary of coverage of the carbon assessment for Hawai'i habitat status map units for the main Hawaiian Islands.

\begin{tabular}{|c|c|c|c|c|c|c|c|c|}
\hline \multirow{2}{*}{ Habitat-status unit } & \multicolumn{7}{|c|}{ Island } & \multirow{2}{*}{ Total } \\
\hline & Kaua'i & O’ahu & Moloka'i & Lāna'i & Maui & Kaho'olawe & Hawai'i & \\
\hline & \multicolumn{8}{|c|}{ Area in square kilometers } \\
\hline Heavily disturbed & 363 & 620 & 60 & 77 & 487 & 0 & 1,083 & 2,690 \\
\hline Native/Alien mix & 723 & 729 & 443 & 238 & 854 & 85 & 2,875 & 5,947 \\
\hline Native dominated & 324 & 200 & 149 & 27 & 464 & 0 & 3,985 & 5,149 \\
\hline$<5 \%$ vegetation & 27 & 4 & 23 & 23 & 84 & 31 & 2,518 & 2,709 \\
\hline \multirow[t]{2}{*}{ Total } & 1,437 & 1,553 & 675 & 365 & 1,888 & 116 & 10,461 & 16,496 \\
\hline & \multicolumn{8}{|c|}{ Percent of total area } \\
\hline Heavily disturbed & 25.2 & 39.9 & 8.9 & 21.0 & 25.8 & 0.1 & 10.4 & 16.3 \\
\hline Native/Alien mix & 50.3 & 46.9 & 65.6 & 65.2 & 45.2 & 73.5 & 27.5 & 36.1 \\
\hline Native dominated & 22.6 & 12.9 & 22.0 & 7.4 & 24.6 & 0.0 & 38.1 & 31.2 \\
\hline$<5 \%$ vegetation & 1.9 & 0.2 & 3.4 & 6.3 & 4.4 & 26.5 & 24.1 & 16.4 \\
\hline
\end{tabular}




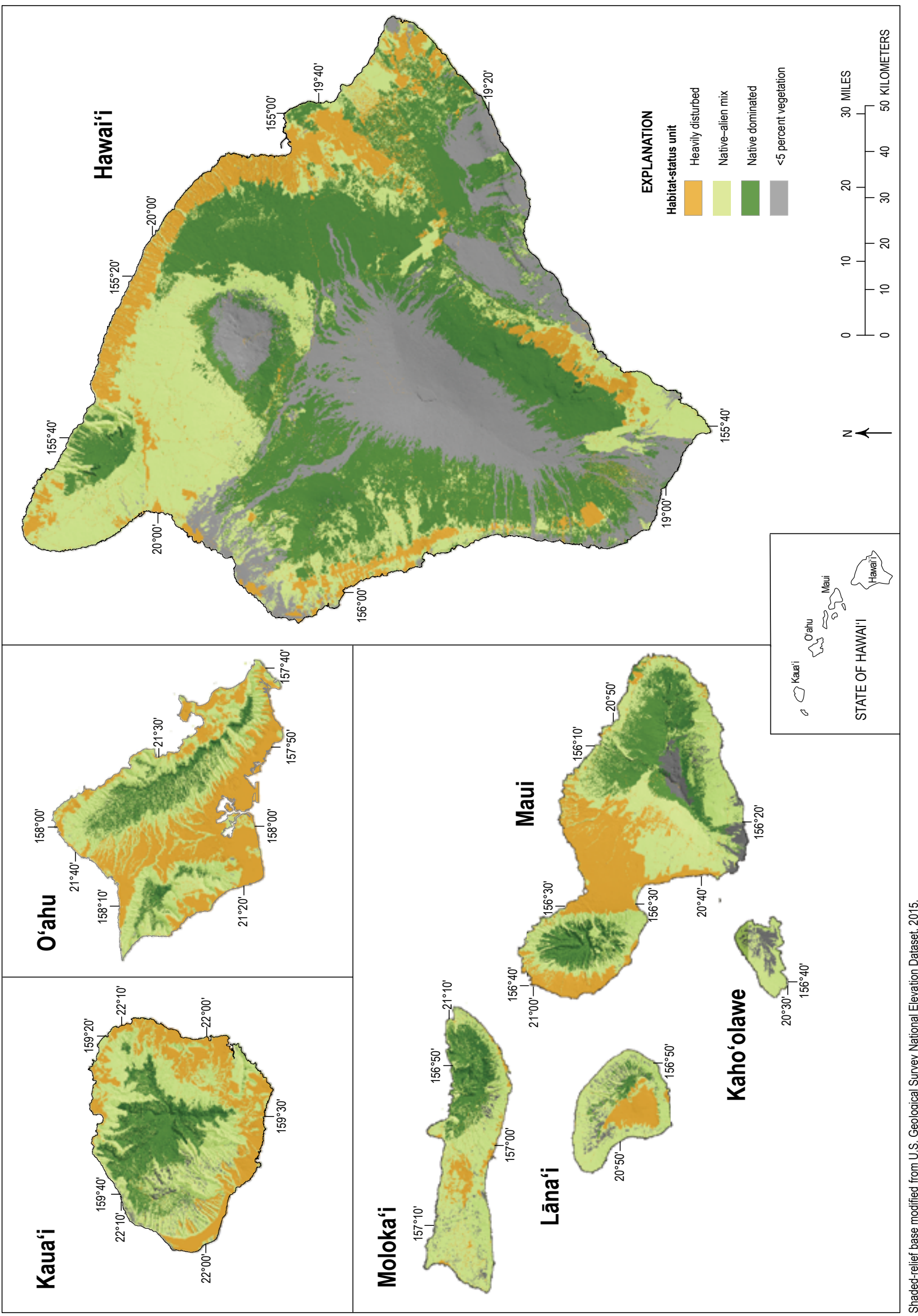

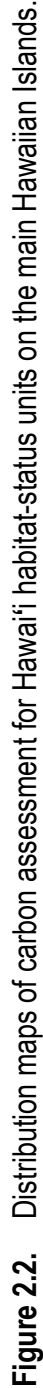


has less than 5 percent vegetation cover; most of this area is in the alpine zone on the islands of Hawai' $i$ and Maui, although some relatively large non-vegetated areas are found on recent lava flows, primarily on the Island of Hawai'i. For the most part this non-vegetated unit can be considered to be native dominated, particularly in the alpine and subalpine zones.

From a vegetation-structure perspective, more than 35 percent of the current landscape on the main Hawaiian Islands is covered by forest, dominated variously by native tree species, alien tree species, or a mix of the two (fig. 2.3; table 2.2). Another 16 percent is mapped as shrubland and approximately 17 percent as grassland. Non-vegetated areas, primarily on Maui and Hawai' $i$ Island, compose almost 19 percent of the map. The remaining area was mapped as either agriculture, developed, or "other" (wetlands and bogs), which compose less than 0.2 percent of the map.

The $13 \mathrm{CAH}$ biome units incorporate a combination of vegetation structure (for example, forest, shrubland, and grassland) and moisture zones from the Price and others (2012) map (fig. 2.4; table 2.3). Although this depiction of the $\mathrm{CAH}$ land-cover map also includes units that relate directly to modification of the landscape by human development, the basic land cover and moisture zones could be generalized across these areas to create the base for the current and future biome maps described in Fortini and others (this volume, chap. 3).

The CAH General Map units are even more detailed and display the distribution of plant communities that incorporate vegetation structure, moisture zones, and status of the dominant vegetation (native dominated, mixed native-alien communities, and alien dominated), as well as land-use units (fig. 2.5; table 2.4). This map level was used as the basis for the overall carbon assessment described in MacKenzie and others (this volume, chap. 7).

Finally, the $48 \mathrm{CAH}$ detailed land-cover units bring dominant species into the unit description (Appendix 1). Although we did not use this level of detail directly in our CAH analysis, these units form the basis for the more generalized units described above. Additionally, this most detailed map level will likely be useful as a base map for other research and management applications in the main Hawaiian Islands.

Table 2.2. Summary of coverage of the carbon assessment for Hawai'i major land-cover map units for the main Hawaiian Islands.

[CAH, carbon assessment for Hawai' $\mathrm{i}$ ]

\begin{tabular}{|c|c|c|c|c|c|c|c|c|}
\hline \multirow{2}{*}{$\begin{array}{l}\text { CAH major land-cover } \\
\text { unit }\end{array}$} & \multicolumn{7}{|c|}{ Island } & \multirow{2}{*}{ Tota } \\
\hline & Kaua'i & O'ahu & Moloka'i & Lāna'i & Maui & Kaho'olawe & Hawai'i & \\
\hline & \multicolumn{8}{|c|}{ Area in square kilometers } \\
\hline Forest & 692 & 675 & 240 & 145 & 754 & 56 & 3,286 & 5,848 \\
\hline Shrubland & 231 & 204 & 308 & 108 & 227 & 14 & 1,628 & 2,719 \\
\hline Grassland & 163 & 110 & 58 & 91 & 321 & 21 & 2,024 & 2,789 \\
\hline Other & 8 & 13 & 5 & 0 & 7 & 0 & 5 & 37 \\
\hline Agriculture & 143 & 131 & 15 & 0 & 266 & 0 & 392 & 948 \\
\hline Developed & 115 & 410 & 29 & 14 & 155 & 1 & 308 & 1,032 \\
\hline Not vegetated & 85 & 8 & 18 & 7 & 155 & 24 & 2,816 & 3,113 \\
\hline \multirow[t]{2}{*}{ Total } & 1,436 & 1,551 & 674 & 365 & 1,886 & 115 & 10,458 & 16,485 \\
\hline & \multicolumn{8}{|c|}{ Percent of total area } \\
\hline Forest & 48.2 & 43.5 & 35.7 & 39.7 & 40.0 & 48.3 & 31.4 & 35.5 \\
\hline Shrubland & 16.1 & 13.1 & 45.6 & 29.6 & 12.1 & 12.1 & 15.6 & 16.5 \\
\hline Grassland & 11.4 & 7.1 & 8.6 & 25.0 & 17.0 & 18.2 & 19.4 & 16.9 \\
\hline Other & 0.5 & 0.8 & 0.7 & 0.1 & 0.4 & 0.0 & 0.0 & 0.2 \\
\hline Agriculture & 10.0 & 8.5 & 2.3 & 0.1 & 14.1 & 0.0 & 3.7 & 5.7 \\
\hline Developed & 8.0 & 26.4 & 4.4 & 3.7 & 8.2 & 0.5 & 2.9 & 6.3 \\
\hline Not vegetated & 5.9 & 0.5 & 2.7 & 1.9 & 8.2 & 20.8 & 26.9 & 18.9 \\
\hline
\end{tabular}




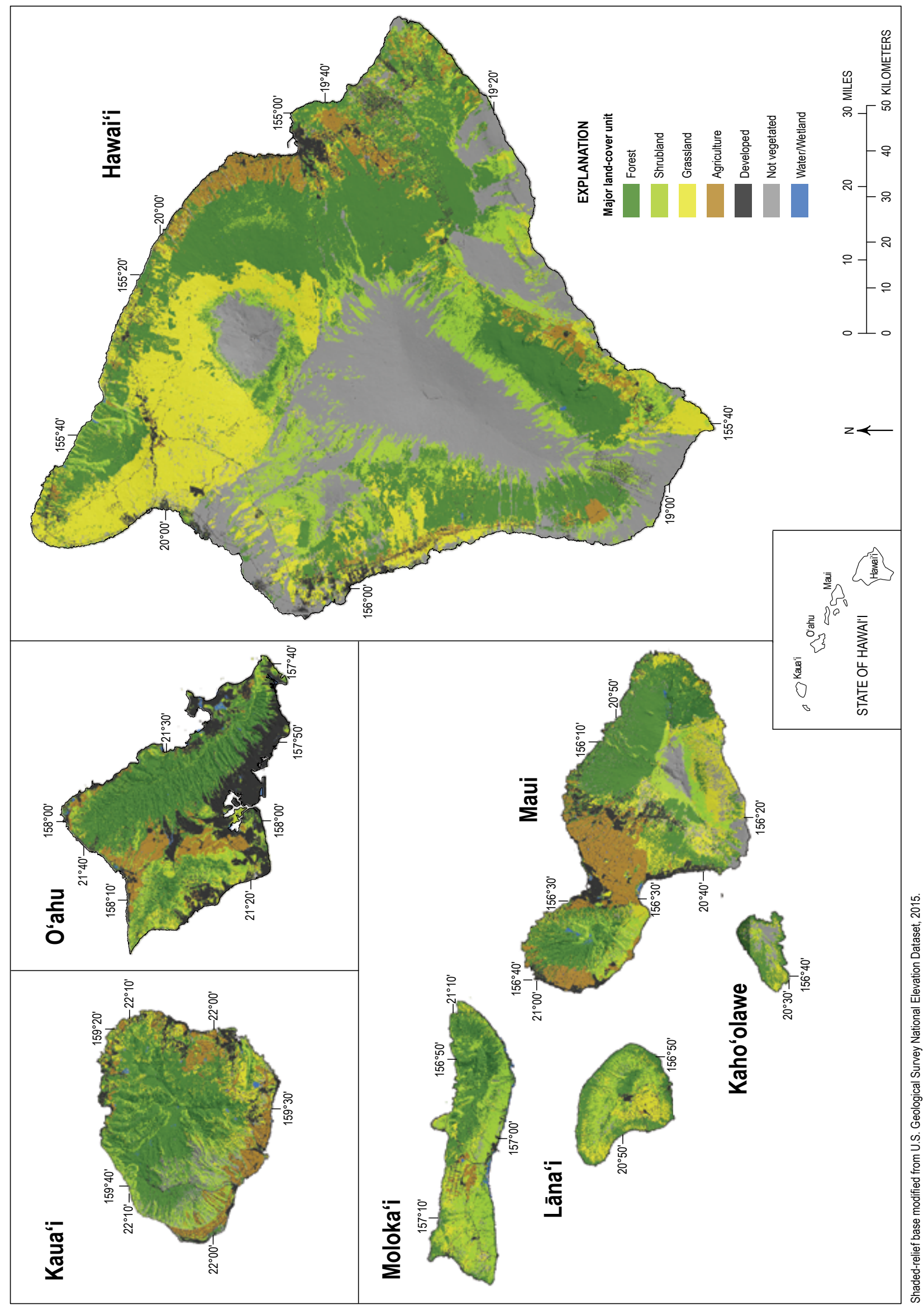

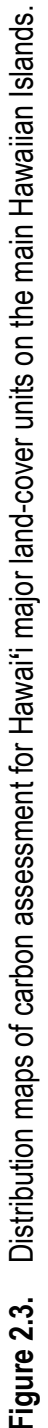


Table 2.3. Summary of coverage of the carbon assessment for Hawai'i biome map units for the main Hawaiian Islands.

[CAH, carbon assessment for Hawai'i]

\begin{tabular}{|c|c|c|c|c|c|c|c|c|}
\hline \multirow{2}{*}{ CAH biome unit } & \multicolumn{7}{|c|}{ Island } & \multirow{2}{*}{ Total } \\
\hline & Kaua'i & O‘ahu & Moloka'i & Lāna'i & Maui & Kaho'olawe & Hawai'i & \\
\hline & \multicolumn{8}{|c|}{ Area in square kilometers } \\
\hline Dry forest & 46 & 97 & 89 & 128 & 143 & 56 & 369 & 927 \\
\hline Mesic forest & 293 & 302 & 73 & 4 & 229 & 0 & 737 & 1,639 \\
\hline Wet forest & 343 & 242 & 70 & 13 & 382 & 0 & 1,988 & 3,039 \\
\hline Dry shrubland & 103 & 129 & 255 & 100 & 107 & 14 & 771 & 1,478 \\
\hline Mesic shrubland & 71 & 55 & 31 & 8 & 70 & 0 & 606 & 841 \\
\hline Wet shrubland & 57 & 20 & 22 & 0 & 50 & 0 & 251 & 399 \\
\hline Dry grassland & 35 & 79 & 52 & 90 & 162 & 21 & 1,099 & 1,537 \\
\hline Mesic grassland & 113 & 30 & 6 & 1 & 150 & 0 & 711 & 1,010 \\
\hline Wet grassland & 16 & 1 & 1 & 0 & 9 & 0 & 214 & 242 \\
\hline Wetland & 8 & 13 & 5 & 0 & 7 & 0 & 5 & 37 \\
\hline Agriculture & 153 & 165 & 24 & 0 & 266 & 0 & 583 & 1,190 \\
\hline Developed & 115 & 410 & 29 & 14 & 155 & 1 & 308 & 1,032 \\
\hline Not vegetated & 85 & 8 & 18 & 7 & 155 & 24 & 2,816 & 3,113 \\
\hline \multirow[t]{2}{*}{ Total } & 1,436 & 1,551 & 674 & 365 & 1,886 & 115 & 10,458 & 16,485 \\
\hline & \multicolumn{8}{|c|}{ Percent of total area } \\
\hline Dry forest & 3.2 & 6.3 & 13.1 & 35.1 & 7.6 & 48.3 & 3.5 & 5.6 \\
\hline Mesic forest & 20.4 & 19.5 & 10.9 & 1.1 & 12.2 & 0.0 & 7.1 & 9.9 \\
\hline Wet forest & 23.9 & 15.6 & 10.4 & 3.5 & 20.2 & 0.0 & 19.0 & 18.4 \\
\hline Dry shrubland & 7.2 & 8.3 & 37.8 & 27.4 & 5.7 & 12.1 & 7.4 & 9.0 \\
\hline Mesic shrubland & 5.0 & 3.6 & 4.6 & 2.1 & 3.7 & 0.0 & 5.8 & 5.1 \\
\hline Wet shrubland & 3.9 & 1.3 & 3.3 & 0.1 & 2.6 & 0.0 & 2.4 & 2.4 \\
\hline Dry grassland & 2.4 & 5.1 & 7.7 & 24.7 & 8.6 & 18.2 & 10.5 & 9.3 \\
\hline Mesic grassland & 7.8 & 1.9 & 0.8 & 0.3 & 7.9 & 0.0 & 6.8 & 6.1 \\
\hline Wet grassland & 1.1 & 0.1 & 0.1 & 0.0 & 0.5 & 0.0 & 2.0 & 1.5 \\
\hline Wetland & 0.5 & 0.8 & 0.7 & 0.1 & 0.4 & 0.0 & 0.0 & 0.2 \\
\hline Agriculture & 10.6 & 10.6 & 3.6 & 0.1 & 14.1 & 0.0 & 5.6 & 7.2 \\
\hline Developed & 8.0 & 26.4 & 4.4 & 3.7 & 8.2 & 0.5 & 2.9 & 6.3 \\
\hline Not vegetated & 5.9 & 0.5 & 2.7 & 1.9 & 8.2 & 20.8 & 26.9 & 18.9 \\
\hline
\end{tabular}


Table 2.4. Summary of coverage of the carbon assessment for Hawai'i general land-cover map units for the main Hawaiian Islands.

[CAH, carbon assessment for Hawai ‘i]

\begin{tabular}{|c|c|c|c|c|c|c|c|c|}
\hline \multirow{2}{*}{$\begin{array}{l}\text { CAH general land-cover } \\
\text { map unit }\end{array}$} & \multicolumn{7}{|c|}{ Island } & \multirow{2}{*}{ Tota } \\
\hline & Kaua'i & O'ahu & Moloka'i & Lāna'i & Maui & Kaho'olawe & Hawai'i & \\
\hline & \multicolumn{8}{|c|}{ Area in square kilometers } \\
\hline Native dry forest & 0 & 0 & 1 & 0 & 1 & 0 & 301 & 302 \\
\hline Native mesic forest & 60 & 18 & 27 & 1 & 67 & 0 & 538 & 711 \\
\hline Native wet forest & 216 & 127 & 60 & 13 & 266 & 0 & 1,755 & 2,437 \\
\hline Mixed dry forest & 0 & 2 & 1 & 0 & 0 & 0 & 0 & 3 \\
\hline Mixed mesic forest & 0 & 29 & 18 & 0 & 0 & 0 & 3 & 50 \\
\hline Mixed wet forest & 0 & 4 & 4 & 0 & 0 & 0 & 3 & 11 \\
\hline Alien dry forest & 46 & 95 & 87 & 128 & 142 & 56 & 68 & 622 \\
\hline Alien mesic forest & 233 & 255 & 28 & 3 & 163 & 0 & 196 & 879 \\
\hline Alien wet forest & 126 & 111 & 6 & 0 & 116 & 0 & 231 & 591 \\
\hline Alien tree plantation & 10 & 33 & 9 & 0 & 0 & 0 & 191 & 243 \\
\hline Native dry shrub & 8 & 0 & 2 & 33 & 54 & 1 & 728 & 825 \\
\hline Native mesic shrub & 0 & 0 & 13 & 3 & 57 & 0 & 526 & 598 \\
\hline Native wet shrub & 38 & 17 & 12 & 0 & 46 & 0 & 174 & 287 \\
\hline Mixed mesic shrub & 0 & 0 & 2 & 0 & 0 & 0 & 0 & 2 \\
\hline Mixed wet shrub & 0 & 0 & 8 & 0 & 0 & 0 & 15 & 23 \\
\hline Alien dry shrub & 95 & 129 & 252 & 67 & 53 & 13 & 43 & 653 \\
\hline Alien mesic shrub & 71 & 55 & 16 & 5 & 14 & 0 & 79 & 241 \\
\hline Alien wet shrub & 19 & 2 & 2 & 0 & 4 & 0 & 61 & 89 \\
\hline Native mesic grassland & 0 & 0 & 0 & 0 & 4 & 0 & 0 & 4 \\
\hline Alien dry grassland & 35 & 79 & 52 & 90 & 162 & 21 & 1,099 & 1,537 \\
\hline Alien mesic grassland & 113 & 30 & 6 & 1 & 145 & 0 & 711 & 1,006 \\
\hline Alien wet grassland & 16 & 1 & 1 & 0 & 9 & 0 & 214 & 242 \\
\hline Wetland & 3 & 4 & 3 & 0 & 4 & 0 & 2 & 16 \\
\hline Agriculture & 143 & 131 & 15 & 0 & 266 & 0 & 392 & 948 \\
\hline Developed & 115 & 410 & 29 & 14 & 155 & 1 & 308 & 1,032 \\
\hline Bare ground & 85 & 8 & 18 & 7 & 155 & 24 & 2,816 & 3,113 \\
\hline Water & 5 & 9 & 2 & 0 & 4 & 0 & 2 & 22 \\
\hline Total & 1,436 & 1,551 & 674 & 365 & 1,886 & 115 & 10,458 & 16,485 \\
\hline
\end{tabular}




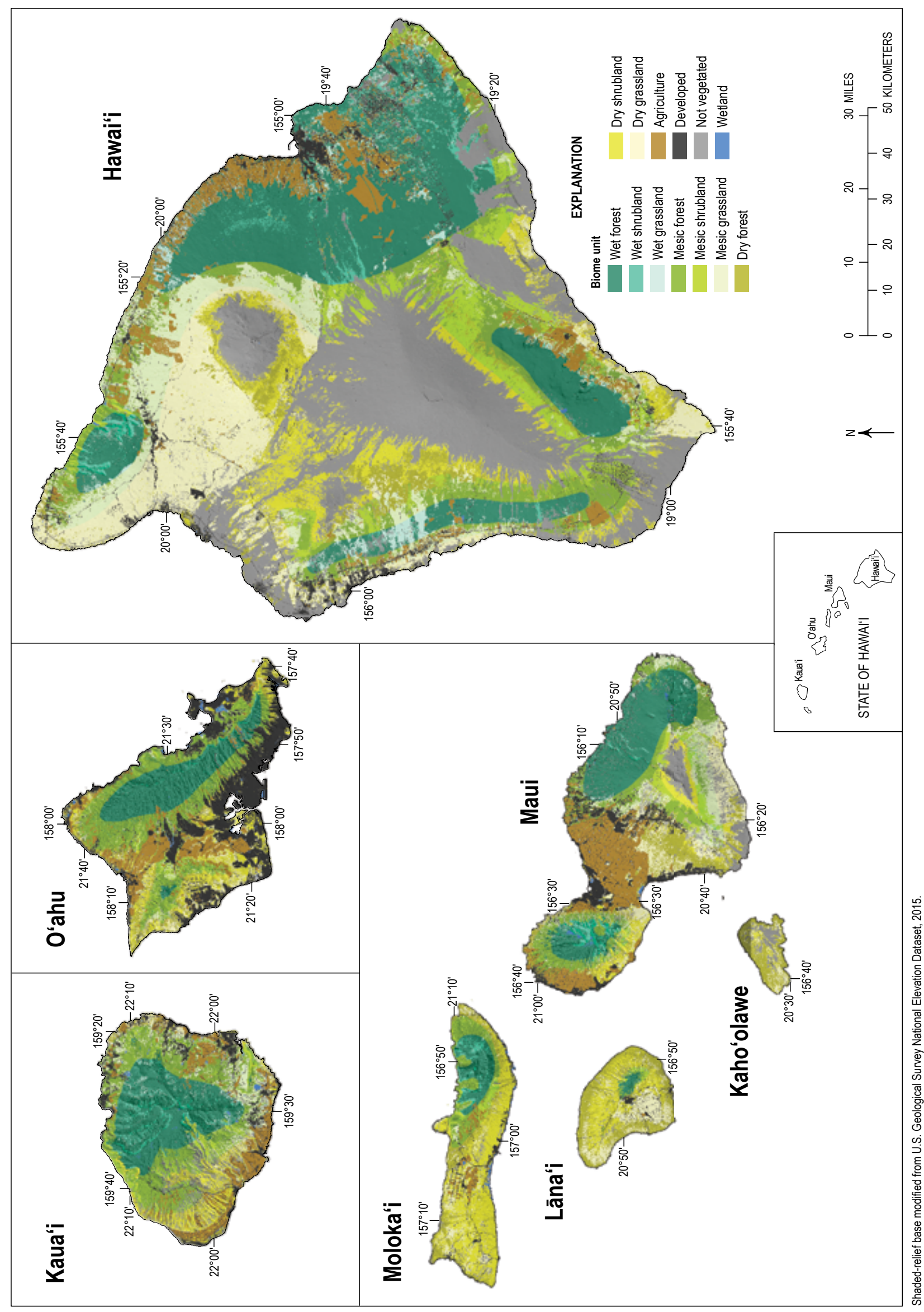

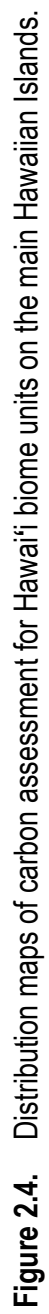




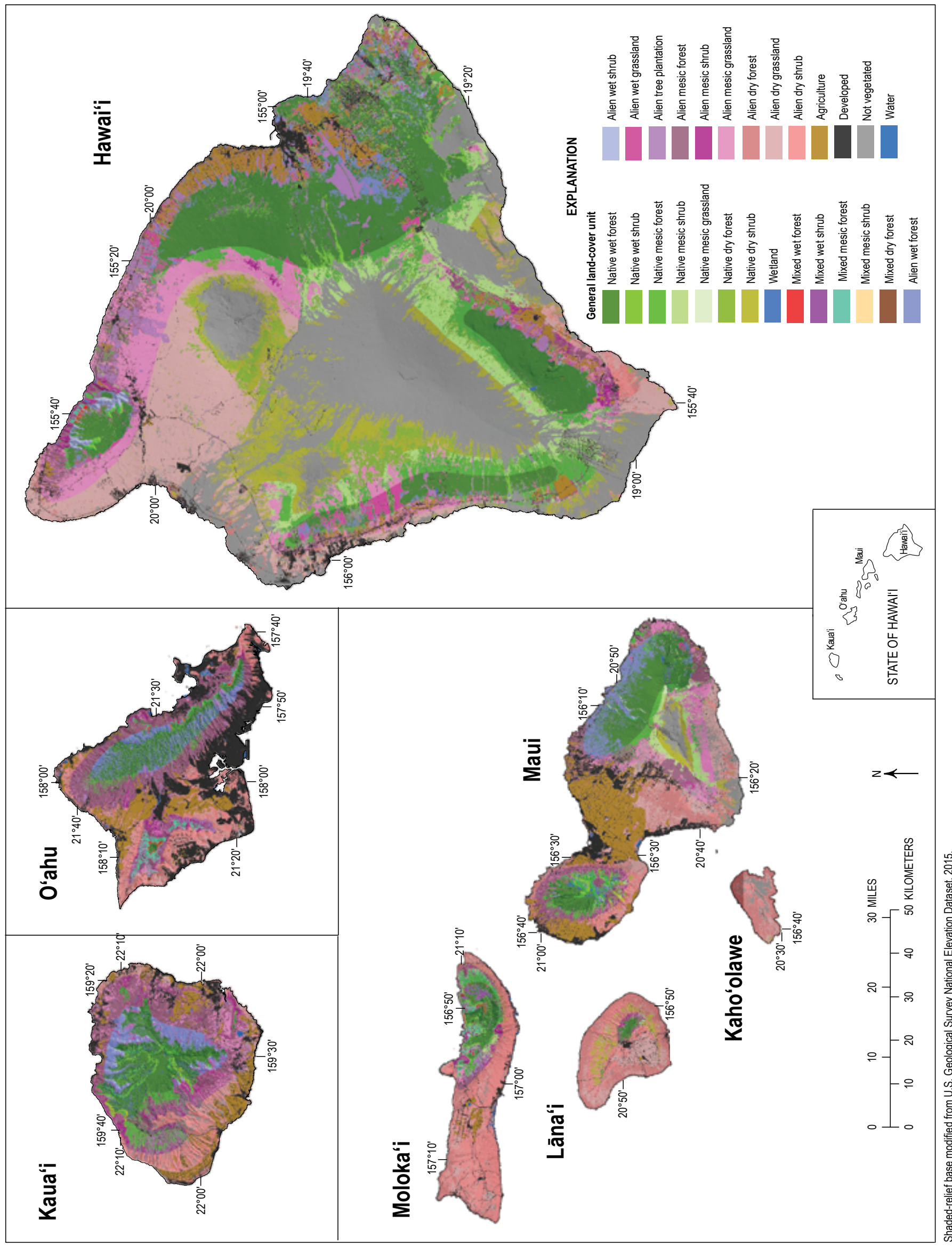

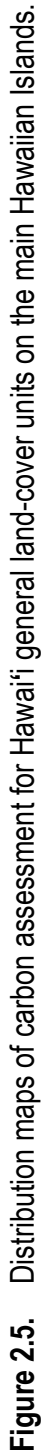




\subsection{References Cited}

ARIS B.V., 2014, GRID Editor for ArcMap: Utrecht, Netherlands, ARIS B.V., http://www.aris.nl/index.php?option=com_content\&V iew $=$ article $\& i d=68 \&$ Itemid $=211$.

Cuddihy, L.W., and Stone, C.P., 1990, Alteration of native Hawaiian vegetation - Effects of humans, their activities and introductions: Honolulu, University of Hawai' $i$ Press, 138 p.

FGDC, 2008, National vegetation classification standard, version 2: U.S. Geological Survey, Federal Geographic Data Committee, Vegetation Subcommittee FGDC-STD-005-2008, 55 p. plus appendixes, http://usnvc.org/wp-content/uploads/2011/02/NVCS V2_FINAL_2008-02.pdf.

Giambelluca, T.W., Chen, Q., Frazier, A.G., Price, J.P., Chen, Y.-L., Chu, P.-S., Eischeid, J.K., and Delparte, D.M., 2013, Online Rainfall Atlas of Hawai' $i$ : Bulletin of the American Meteorological Society, v. 94, p. 313-316. (Available at http:// rainfall.geography.hawaii.edu.)

Giambelluca, T.W., and Schroeder, T.A., 1998, Climate, in Juvik, S.P., and Juvik, J.O., eds., Atlas of Hawai'i: Honolulu, University of Hawai'i Press, p. 49-59.

Gon, S.M., III, Allison, A., Cannarella, R.J., Jacobi, J.D., Kaneshiro, K.Y., Kido, M.H., Lane-Kamahele, M., and Miller, S.E., 2006, A GAP analysis of Hawaii-Final Report: U.S. Geological Survey, Research Corporation of the University of Hawai'i, 163 p., plus maps and appendixes.

Juvik, J.O., 1998, Biogeography, in Juvik, S.P., and Juvik, J.O., eds., Atlas of Hawai'i: Honolulu, University of Hawai'i Press, p. 103-106.

Mueller-Dombois, D., Jacobi, J.D., Boehmer, H.J., and Price, J.P., 2013, 'Ōhi'a Lehua Rainforest-Born Among Hawaiian Volcanoes, Evolved in Isolation; The story of a dynamic ecosystem with relevance to forests worldwide: Honolulu, Friends of the Joseph Rock Herbarium, 292 p.

NatureServe, 2010, International Ecological Classification Standard-Terrestrial Ecological Classifications; Descriptions of Ecological Systems for Modeling of LANDFIRE Biophysical Settings, State of Hawai'i: Arlington, Va., NatureServe, 59 p.

NatureServe, 2011, Terrestrial Ecological ClassificationsEcological Systems of Hawai'i: Arlington, Va., and Boulder, Colo., NatureServe Technical Report, 37 p.

National Oceanic and Atmospheric Administration, 2012, Coastal Change Analysis Program (C-CAP) 2005 Hawaii Regional Land Cover Map: Charleston, S.C., NOAA’s Ocean Service, Office for Coastal Management, available at http://www.csc.noaa.gov/ digitalcoast/data/ccapregional.
Pictometery International, 2014, Pictometry Imagery: Rochester, N.Y., Pictometry International, http://www. eagleview.com/Products/ImageSolutionsAnalytics/ PictometryImagery.aspx.

Pratt, L.W., and Gon, S.M., III, 1998, Terrestrial ecosystems, in Juvik, S.P., and Juvik, J.O., eds., Atlas of Hawai'i: Honolulu, University of Hawai'i Press, p. 121-129.

Price, J.P., Jacobi, J.D., Gon, S.M., III, Matsuwaki, D., Mehrhoff, L., Wagner, W., Lucas, M., and Rowe, B., 2012, Mapping plant species ranges in the Hawaiian Islands - Developing a methodology and associated GIS layers: U.S. Geological Survey Open-File Report 2012-1192, 34 p., 1 appendix (species table), 1,158 maps, available at http://pubs.usgs.gov/ of/2012/1192/.

Price, J.P., and Wagner, W.L., 2011, A Phylogenetic basis for species-area relationships among three Pacific Island floras: American Journal of Botany, v. 98, no. 3, p. 449-459, available at http://dx.doi.org/10.3732/ajb.1000388.

Rollins, M.G., 2009, LANDFIRE: A nationally consistent vegetation, wildland fire, and fuel assessment: International Journal of Wildland Fire, v. 18, p. 235-249.

Staples, G.W., and Cowie, R.H., eds., 2001, Hawai'i's Invasive Species - A guide to invasive plants and animals in the Hawaiian Islands (1st ed.): Honolulu, Mutual Publishing and the Bishop Museum Press, 114 p.

U.S. Census Bureau, 2014, TIGER/Line shapefiles and TIGER/Line files: U.S. Census Bureau web page, https:// www.census.gov/geo/maps-data/data/tiger-line.html.

U.S. Geological Survey, 2009, LANDFIRE.HI_100EVCHawai'i Existing Vegetation Type Layer: U.S. Geological Survey, http://landfire.cr.usgs.gov/viewer/viewer.html?b box $=-164,15.79,-151.67,25.48$.

Wagner, W.L., and Funk, V.A., eds., 1995, Hawaiian biogeography_Evolution on a hot spot archipelago: Washington, D.C., Smithsonian Institution Press, 467 p.

Wagner, W.L., Herbst, D.R., and Sohmer, S.H., 1999, Manual of the Flowering Plants of Hawai'i ( $2 \mathrm{~d}$ ed.): Honolulu, University of Hawai'i Press, Bishop Museum Press, 1,919 p.

Warshauer, F.R., 1998, Alien species and threats to native ecology, in Juvik, S.P., and Juvik, J.O., eds., Atlas of Hawai'i: Honolulu, University of Hawai'i Press, p. 146-149.

Ziegler, A.C., 2002, Hawaiian Natural History, Ecology, and Evolution: Honolulu, University of Hawaii Press, 477 p. 


\title{
Chapter 3. Projecting End-of-Century Shifts in the Spatial Pattern of Plant-Available Water Across Hawai'i to Assess Implications to Vegetation Shifts
}

\author{
By Lucas B. Fortini, ${ }^{1}$ James D. Jacobi, ${ }^{1}$ and Jonathan P. Price ${ }^{2}$
}

\subsection{Highlights}

- Anticipating potential shifts in plant communities has been a major challenge in climate change ecology. In Hawai $i$, where conservation efforts tend to be habitat focused, the lack of projections of vegetation shifts under future climate is a major knowledge gap for developing management actions aimed at climate change mitigation and adaptation.

- As a first approximation of such changes, we have modeled potential shifts of terrestrial vegetation across the Hawaiian landscape between now and the end of this century. Our approach relies on modeling the relation between current climate and the distribution of broad, climatically determined moisture zones (for example, dry, mesic, and wet areas) that form the basis of natural landcover classification classes in Hawai' $i$ (for example, dry forests, wet forests, mesic shrublands).

- In this approach we modeled the suitability of the landscape to each moisture zone based on its relation to mean annual temperature, wet season precipitation, and dry season precipitation and then integrated these individual moisturezone models into landscape moisture-zone projections under current and end-of-century climate scenarios.

- We integrated our moisture-zone projections into a detailed Hawai' $i$ land-cover map to derive a first approximation of climate-based shifts in land cover in Hawai' $i$. The results show we can accurately replicate the current distribution of Hawaiian moisture zones using simple climate metrics based on temperature and precipitation.

- Our resulting models identify areas in the landscape where projected shifts in climate may lead to moisture-driven vegetation shifts with clear consequences to overall carbon storage across the archipelago.

${ }^{1}$ U.S. Geological Survey.

${ }^{2}$ University of Hawai' $i$ at Hilo.

\subsection{Introduction}

Sharp climate and elevation gradients in the main Hawaiian Islands lead to huge vegetation variation over relatively short distances. Hawai'i possesses 25 of the 35 Holdridge global life zones (Asner and others 2005), which results in large variability in biomass across the Hawaiian landscape (Asner and others, 2009, 2011). This variability means potential climate shifts can have major implications to land carbon through shifts in Hawai' $i$ vegetation distribution. An important step in quantifying the potential changes in carbon storage owing to projected climate shifts is quantifying how the vegetation may change over time under future scenarios. However, projecting potential shifts in vegetation and plant communities has been a major challenge in climate change research (Cramer and others, 2001). There are clear implications of such shifts to the conservation of Hawaiian native species and their habitat, especially given the number of endangered species in Hawai' $i$ and their high vulnerability to climate change (Fortini and others, 2013, 2015; Krushelnycky and others, 2013). This gap in knowledge of potential vegetation shifts in response to climate also hinders the quantification of shifts in potential landscape carbon storage that can allow for evaluation of the viability of carbon sequestration efforts (Bachelet and others, 2001; Lucht and others, 2006; Gibbs, 2007).

For a relatively small isolated land area such as Hawai $i$, there are few research approaches available to help us explore the potential climate-based shifts in vegetation. Vegetationdistribution projections based on global vegetation models do not typically apply to isolated islands. Although part of the reason is the coarse spatial resolution of most global vegetation models (Bonan and others, 2003; Gonzalez and others, 2010; Pavlick and others, 2013), another major challenge arises from the numerous differences among island and continental systems under which vegetation models are parameterized. For instance, isolated disharmonic flora (Ziegler, 2002), which lead to differences in species richness (Ostertag and others, 2014), fire prevalence and behavior (Benoit and others, 2009; Ellsworth and others, 2013), and ongoing biological invasions (Asner and others, 2008; Mascaro and others, 2008), indicate mechanistic models parameterized for continental systems are of limited applicability to Hawai' $i$ and other isolated archipelagos. 
Given the lack of data necessary for the proper parameterization of mechanistic vegetation models in Hawai' $i$ and other similarly isolated islands (Hartig and others, 2012), we attempt to provide a coarse first approximation of the impacts of projected climate shifts to vegetation across Hawai' $i$ using a simple yet novel approach. Our approach relies on modeling the relation between current climate and the distribution of broad climatically determined moisture zones that form the basis of natural land-cover classification classes in Hawai' $i$ (for example, dry forests, wet forests, mesic shrublands; Gagne and Cuddihy, 1990; Gon, 2006; Rollins, 2009; Price and others, 2012). In this approach we first model the suitability of the landscape to each moisture zone based on variability of mean annual temperature (MAT), wet season precipitation, and dry season precipitation and then integrate these individual models into landscape moisturezone projections under current and end-of-century climate scenarios. Additionally, we use a novel calibration algorithm to ensure unbiased projections of prevalence among modeled moisture-zone classes under current and future climate. Lastly, to approximate how these shifts in moisture zone may differentially impact forests, shrublands, and grasslands across Hawai' $i$ and their carbon storage potential, we integrate our moisture-zone projections to a Hawai'i GAP Analysis Program (HIGAP) vegetation structure map (Jacobi and others, this volume, chap. 2).

\subsection{Input Data and Methods}

\subsubsection{Land-cover Data and Processing}

As baseline data for our projections, we used the map of current distribution of moisture zones across Hawai' $i$ (Price and others, 2012). The moisture-zone map describes the variability of plant-available moisture across Hawai' $i$ and has been used in most recent land-cover mapping efforts for the islands. This moisture-zone classification is primarily based on annual precipitation and potential evapotranspiration (thus also being a function of temperature and humidity), but also considers the distribution of independently derived vegetation moisture zones (Jacobi, 1989). The moisture-zone map is based on three generalized moisture classes (dry, mesic, and wet) that reflect the way vegetation types are commonly subcategorized in Hawai'i (for example, wet versus mesic forests). In broad terms these moisture classes can be described as areas where the difference between mean annual precipitation (MAP) and potential evapotranspiration (PET) is more than 1,661 mm (wet), between 0 and 1,660 mm (mesic), and less than $0 \mathrm{~mm}$ (dry) (Price and others, 2007). Prior to all analyses, we resampled the moisture-zone map to $500-\mathrm{m}$ pixel resolution using a majority filter to reduce the computational time required to run models (fig. 3.1).

\subsubsection{Projecting Moisture-Zone Distributions Under Current and Future Climate}

We projected current and future distribution of moisture zones across the Hawaiian Islands using an approach based on the comparative suitability of the Hawaiian landscape to each of the three moisture zones considered. In this approach, we create baseline and end-of-century landscape projections based on multiple iterations of our moisture-zone model (fig. 3.2). Each iteration of the model uses a stratified random sample of the baseline map (the training set) to determine the suitability of the landscape to each moisture zone based on climate predictors alone (individual moisture-zone models) using a boosted regression tree approach (BRT; fig. 3.3). Hence, individual iterations only provide partial coverage of landscape under current climate because projections are not applied to parts of landscape used for model fitting to avoid overfitting. We chose BRT based on the method's overall good performance in similar efforts to model ecological distribution patterns (Elith and others, 2008; Hastie and others, 2011). An initial test showed similar accuracies for moisture-zone models based on simpler Mahalanobis distance-based methods. However, owing to the smaller computational requirements and wider acceptability of BRT, we used BRT for the remainder of our reported models. BRT is an increasingly common ecological modeling method frequently used in species distribution modeling owing to its good model fits. To merge individual moisture-zone models into a single projection (a multi-moisture-zone projection), we used a simple algorithm that assigns a moisture zone to each landscape cell based simply on which moisture zone has the highest model-derived suitability for that location (fig. 3.4). Comparisons with a simpler multinomial BRT approach showed that it provided less accurate and more biased model outputs compared to our approach.

All individual BRT models use optimal settings found in preliminary tests including using a 0.01 learning rate, a tree complexity of 5, and a 0.5 bag fraction (Elith and others, 2008). The number of trees in each model was optimized to balance predictive power versus generalization of models (Hijmans and others, 2012). All models and analyses were developed in the $\mathrm{R}$ programming language (R Core Team, 2014) using the dismo, gbm, and raster packages (Ridgeway, 2005; Hijmans and others, 2012, 2014)

\subsubsection{Model Replicates}

To limit the effect of individual training points to projection outcomes, we ran each model step 200 times using 80 percent of the baseline moisture-zone map for model fitting (the training set, $\mathrm{n}=51,992$ ) and 20 percent for model evaluation (the evaluation set, $\mathrm{n}=12,998)$. Each model iteration splits the data using a stratified random sampling algorithm with respect to moisture-zone prevalence across islands in the original baseline map. Our approach was based on two sets of model runs (see Moisture-zone model workflow box below): a first step used to fit and calibrate our models (see section 3.3.2.2; figs. 3.2 through 3.4) and a second step to apply 


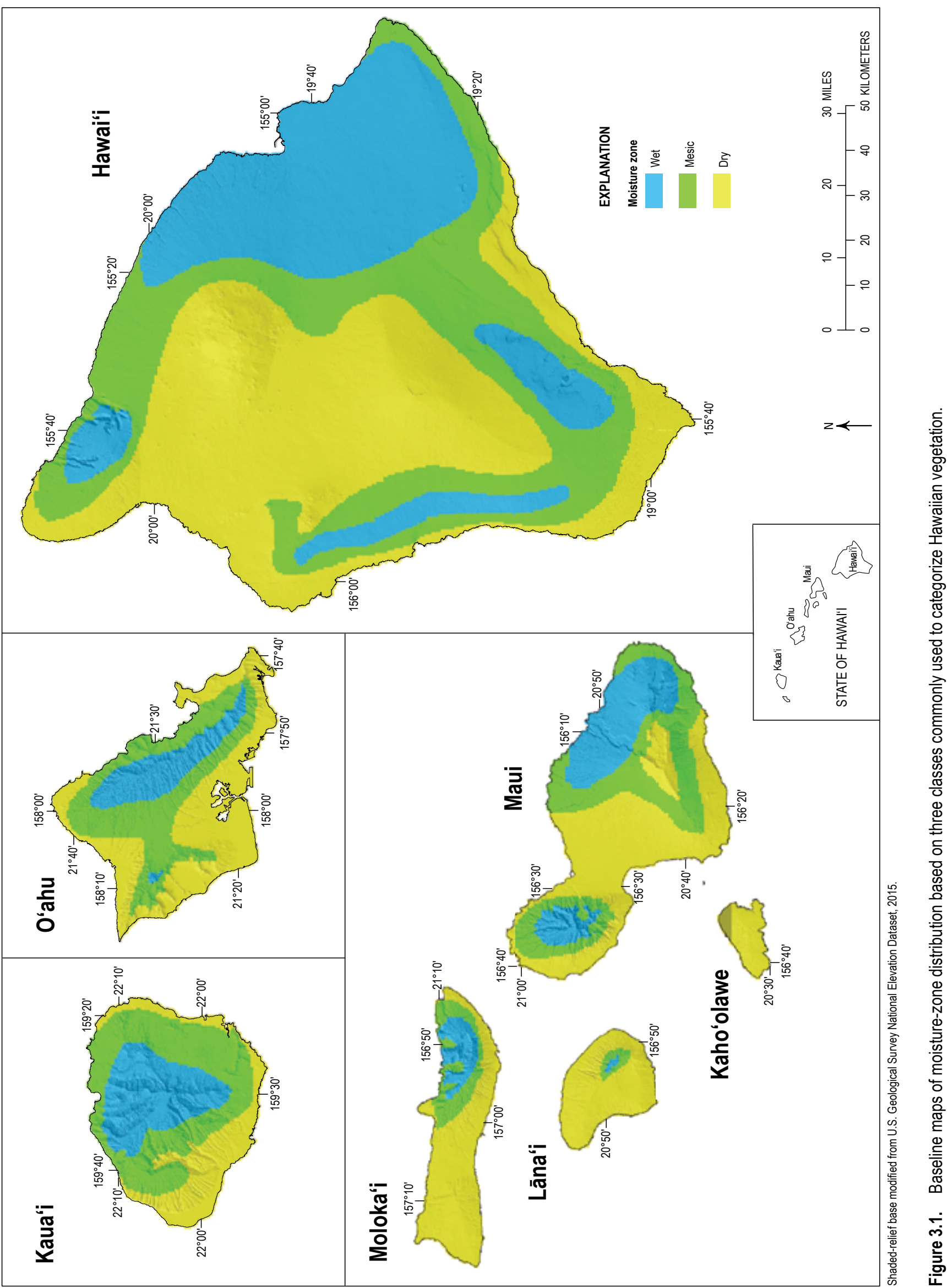




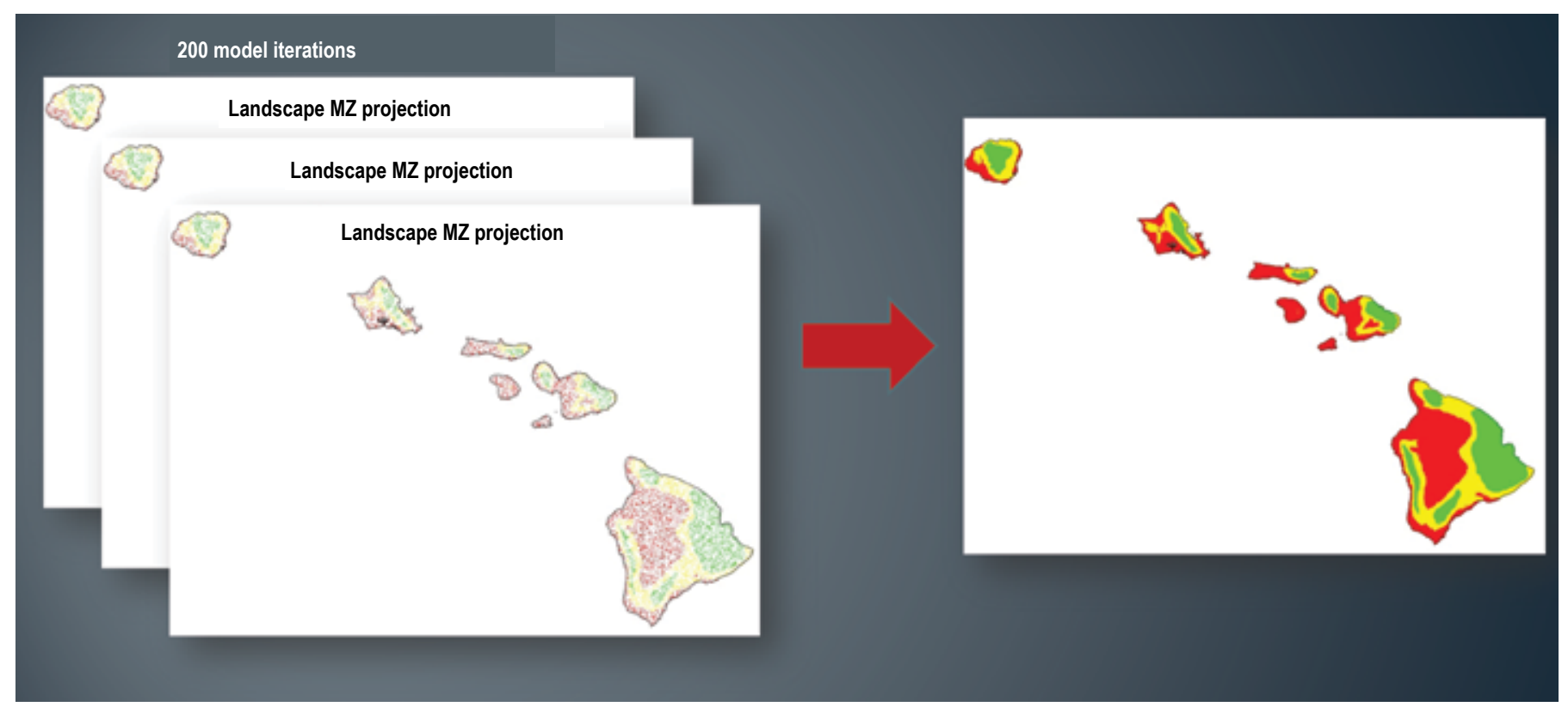

Figure 3.2. Diagram illustrating the combination of multiple partial-coverage landscape moisture-zone projections into a final landscape moisturezone projection. Final projection values are based on most frequent moisture-zone projection across iterations for each raster cell. MZ, moisture zone.

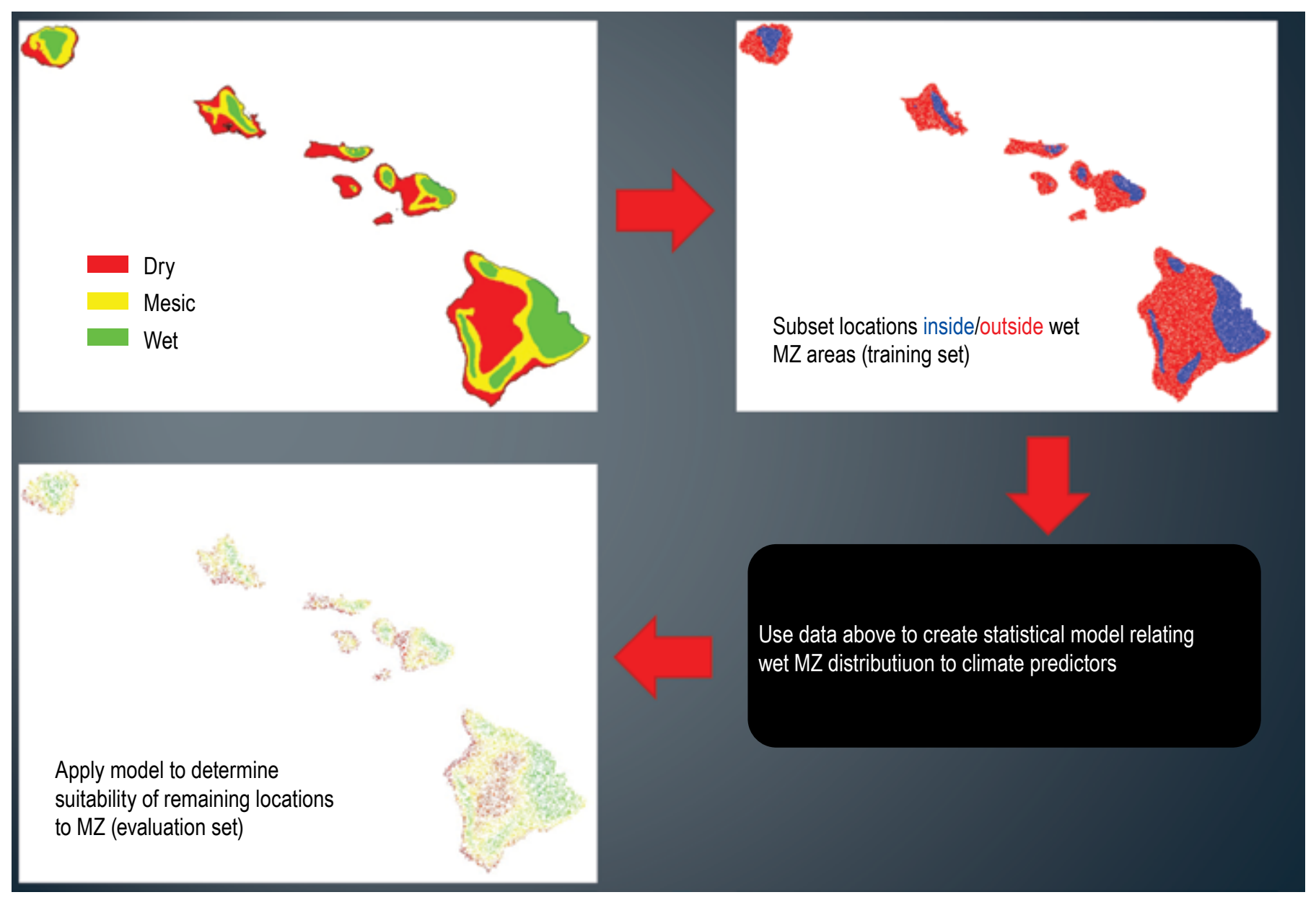

Figure 3.3. Diagram illustrating the fitting of the model describing the suitability of the landscape to individual moisture zones. This process uses the baseline moisture-zone map (fig. 3.1) for model training and evaluation. MZ, moisture zone. 


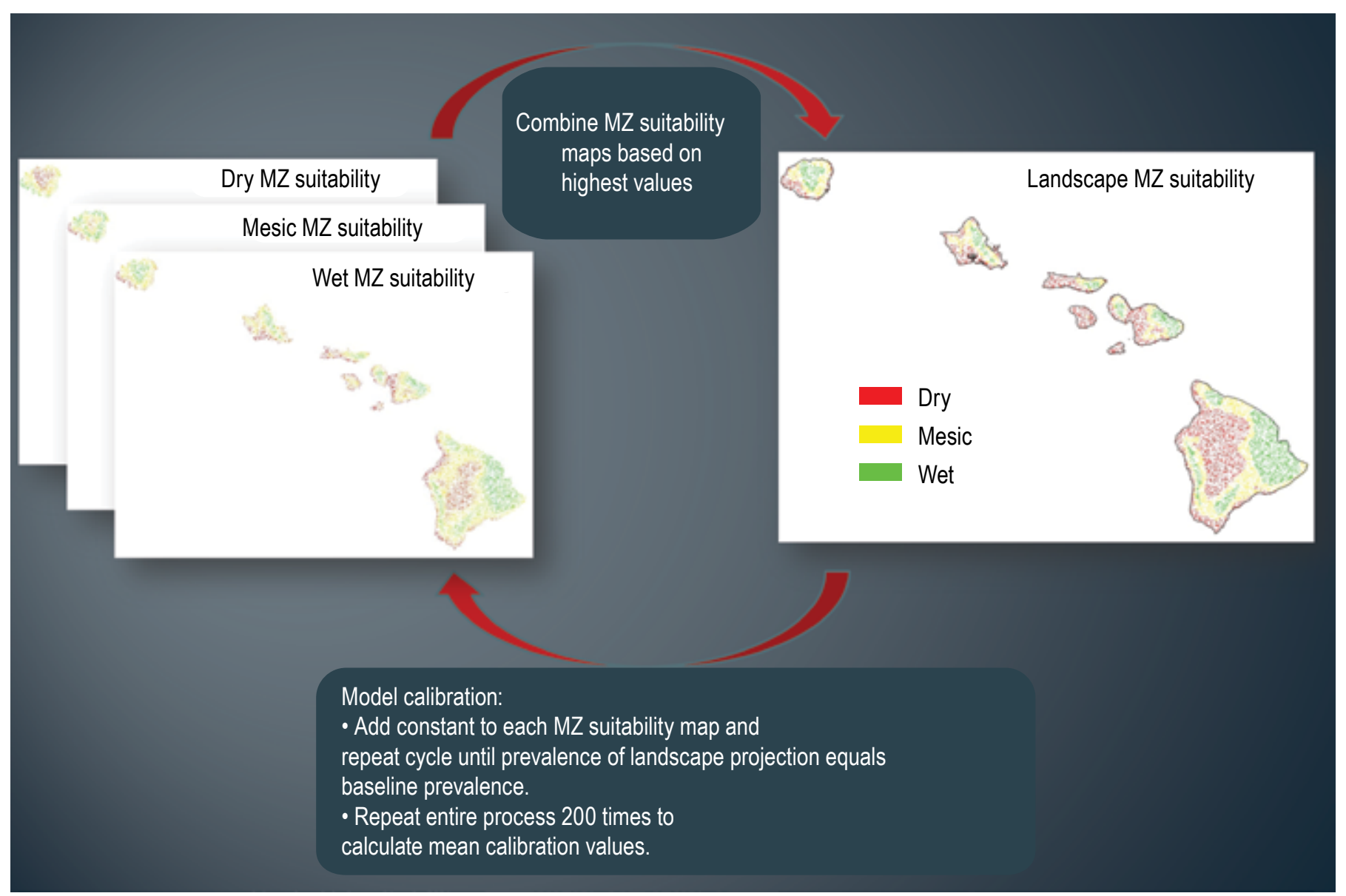

Figure 3.4. Diagram illustrating the integration of individual moisture-zone suitability models (fig. 3.2) into landscape moisture-zone projections. This iterative procedure includes a calibration step to minimize bias in landscape projections. Resulting Landscape moisture-zone projections do not have 100 percent landscape coverage as locations used for model fitting are excluded from output maps. MZ, moisture zone.

\section{Moisture-zone model workflow:}

Step 1: Model fitting and calibration under current climate (200 iterations)

- For each iteration:

- Randomly split baseline cover and predictor maps into training (80 percent) and evaluation (20 percent) sets

- For each moisture zone (fig. 3.2):

- Fit BRT model using training set

- Create moisture-zone suitability map using fitted model and evaluation set

- Create landscape moisture-zone projection based on all moisture-zone suitability maps (fig. 3.3)

- Calibrate landscape projection so its biome prevalence equals baseline prevalence

- Create mean calibration constants from all fitting and calibration iterations

Step 2: Model projections for baseline and future scenarios (200 calibrated runs, fig. 3.4)

- For each model iteration (baseline and future scenarios):

- Re-apply moisture zone fitted models with mean calibrations

- To current climate dataset

- To future climate dataset

Step 3: Create final current and future landscape projections

- Create final maps based on most frequent moisture-zone projection across model runs 
the calibrated models under current and future climate to create our final landscape moisture-zone projections (see section 3.3.2.3; fig. 3.2).

\subsubsection{Model Calibration Runs}

Although the winner-takes-all approach to integrate multiple vegetation models into a single landscape model has been previously used (Tovar and others, 2013), we introduce a novel and simple calibration procedure that aims to minimize bias in final projections (fig. 3.3). This is necessary because there may be differences in model sensitivity and fit across individual moisture zones that could lead to bias in a final landscape classification. If this bias is consistent across model iterations, a standard model averaging approach will not reduce it. Hence, in this procedure, after evaluating current moisturezone projection bias in terms of deviations in moisture-zone prevalence between baseline moisture-zone distribution and current model projections for the evaluation set, a search algorithm incrementally adds or subtracts a constant to the suitability scores of each individual moisture zone until the subsequent landscape moisture-zone projection has prevalence across moisture zones within 1 percent of baseline prevalence. This calibration routine is analogous to presence/absence thresholding algorithms commonly used in species distribution models aimed at yielding projections with equal omission and commission errors (Jiménez-Valverde and Lobo, 2007; Liu and others, 2011). We repeated the model fitting, evaluation, and calibration steps 200 times using different evaluation and training sets to determine the final average model calibration constants to be applied in all calibrated final models.

\subsubsection{Calibrated Model Runs and Final Projections}

Following calibration, we projected 200 replicates of our model across the archipelago based on our current and future climate predictors, along with the average calibration values calculated above (fig. 3.4). The output of individual replicates does not yield a complete moisture-zone coverage map for current climate as the calibrated model is not applied to the training set locations to avoid overly confident projections. However, as each model replicate assigns the most likely moisture zone for 20 percent of the landscape, the final mean landscape projection under current and future climate is based on the most frequently predicted moisture zone for a given location. Lastly, we quantify uncertainty in our final model projections by calculating the ensemble committee agreement across all model iterations. This is calculated as the frequency at which the projected cover for a location is projected across all model replicates, where, for instance, a value of 0.8 indicates that 80 percent of model iterations assigned the same moisture zone to a given location.

\subsubsection{Projection Integration with Land Cover}

To determine the implications of moisture-zone changes to Hawaiian land cover, we integrated our current and future moisture-zone projections with a coarse vegetation map based on the carbon assessment for Hawai' $i$ (CAH) land-cover map by Jacobi and others (this volume, chap. 2). The CAH map is a detailed representation of current vegetation distribution across the main Hawaiian Islands based on multiple data sources resulting in 48 cover classes. As with other Hawaiian land-cover maps (Rollins, 2009), the CAH land-cover map stratifies most non-anthropogenic cover types into moisture-zone subclasses. For the purpose of our simplistic land-cover analysis, we grouped the original classes into forest, shrubland, and grassland general classes resampled to 500-m resolution, excluding all original CAH land-cover classes that did not clearly fit into these three categories (table 3.1). This step not only simplified cover types considered but also removed all moisture-zone associations from the HIGAP map. We then simply merged our modeled moisture-zone map with the moisture-less HIGAP map using either the current or future moisture-zone projections. This overlay analysis allowed us to get a first approximation of the differential impact of projected moisture-zone shifts in forest, shrubland, and grassland areas across the state.

\subsubsection{Environmental Predictors}

We derived all climatic variables used as predictors in our models from current and future monthly temperature minimums and maximums (Tmin, Tmax) and precipitation data. We obtained current monthly precipitation and Tmin and Tmax data from 250-m resolution datasets (Giambelluca and others, 2013, 2014). We calculated mean annual wet season (November-April) and dry season (May-October) temperature and precipitation using the R package "raster" based on the monthly rainfall and temperature data (Hijmans and others, 2014). We calculated future yearly and seasonal climatic indicators using the same procedure as for the baseline data. However, before calculating yearly and seasonal indicators we derived the end-of-century values for monthly Tmin, Tmax, and precipitation by integrating climate projections with current climate estimates. To do that, we first calculated the projected change between 1990 and 2010 and between 2080 and 2100 for each monthly variable developed from the Hawaiian Regional Climate Model (HRCM) with 1-km spatial resolution for Maui and $3 \mathrm{~km}$ for all other islands (Zhang and others, 2012). We then added these delta values to current monthly climate values before recalculating all yearly and seasonal variables. The HRCM-based climate projections show an average of $2.5^{\circ} \mathrm{C}$ warming over the islands, but with a clear increased warming at higher versus lower elevations $\left(3.4^{\circ} \mathrm{C}\right.$ versus $2.2^{\circ} \mathrm{C}$, respectively), as documented in previous studies (Beniston and others, 1997; Diaz and Bradley, 1997; Rangwala and others, 2013). Predicted precipitation shifts include increased precipitation in windward wet areas of Hawai ${ }^{\circ} i$ and Maui, but general slight drying trends across the drier areas of the State.

The HRCM is based on the Weather Research and Forecasting model ver. 3.3 and uses the SRES A1B emission scenario and the mean of multiple CMIP3 global circulation 
Table 3.1. Revised Hawaiłi GAPAnalysis Program cover classes and their relation to our simplified land-use map integrated with current and future moisturezone maps.

[Data from Jacobi and others (this volume, chap. 2). HIGAP, Hawai'i GAP Analysis Program]

\begin{tabular}{|c|c|c|c|}
\hline HIGAP cover class & $\begin{array}{l}\text { Simplified cover } \\
\text { class }\end{array}$ & HIGAP cover class & $\begin{array}{c}\text { Simplified cover } \\
\text { class }\end{array}$ \\
\hline Alien dry forest & Forest & Alien mesic grassland & Grassland \\
\hline Alien mesic forest & Forest & Alien wet grassland & Grassland \\
\hline Alien wet forest & Forest & Native Deschampsia grassland & Grassland \\
\hline Closed Hala forest & Forest & Native bog community & Other \\
\hline Closed koa-ohia mesic forest & Forest & Wetland vegetation & Other \\
\hline Closed ohia dry forest & Forest & Developed open space & Other \\
\hline Closed ohia mesic forest & Forest & Low-intensity developed & Other \\
\hline Closed ohia wet forest & Forest & Medium-intensity developed & Other \\
\hline Kiawe dry forest and shrubland & Forest & High-intensity developed & Other \\
\hline Mixed native-alien wet forest & Forest & Alien mesic shrubland & Shrubland \\
\hline Native mesic to dry forest and shrubland & Forest & Alien wet shrubland & Shrubland \\
\hline Open koa-mamane dry forest & Forest & Mixed native-alien dry cliff community & Shrubland \\
\hline Open koa-ohia mesic forest & Forest & Mixed native-alien mesic shrubs and grass & Shrubland \\
\hline Open koa-ohia wet forest & Forest & Mixed native-alien wet shrubs and grasses & Shrubland \\
\hline Open ohia dry forest & Forest & Native wet cliff community & Shrubland \\
\hline Open ohia mesic forest & Forest & Native dry shrubland & Shrubland \\
\hline Open ohia wet forest & Forest & Native mesic shrubland & Shrubland \\
\hline Mixed mamane-naio-native trees dry woodland & Forest & Native wet shrubland & Shrubland \\
\hline
\end{tabular}

models (GCMs) (Zhang and others, 2012). The HRCM projections are based on a substantial regional dynamic climate model which replicates the regional and island climate mechanisms that largely dictate local climate, such as extreme orographic-based precipitation gradients and trade-wind inversions (Zhang and others, 2012). Because of computational limitations, only a single end-of-century climate projection is available from the HRCM. Although this limits our analysis to consider a single future climate scenario, without this downscaled effort, preliminary analysis showed available GCM outputs commonly used elsewhere are too coarse to represent the steep environmental gradients present across the archipelago.

We selected MAT, wet season precipitation, and dry season precipitation as our three predictors of moisture-zone distribution. Preliminary analysis showed models using a combination of MAT and MAP performed as well or better than most other possible two-climatic-variable combinations. However, the substitution of MAP with wet and dry season precipitation greatly improved the accuracy of our models, especially in areas where seasonal precipitation patterns are markedly different from annual values (Price and others, 2012).

\subsection{Results}

\subsubsection{Current Moisture-Zone Projections and Model Evaluation}

Overall, the current broad geographical pattern of potential moisture-zone distribution across the Hawaiian landscape was well replicated using our three predictors (fig. 3.5). The accuracy of our landscape model based on our calibrated multi-moisture-zone projections for current climate was very high $(0.938 \pm 0.002$ s.d.). An error matrix comparing our mean current projection with the original moisture-zone baseline map shows what types of errors were most common in our projections (table 3.2). Overall, the dry moisture zone was our most accurately predicted moisture zone ( 0.957 accuracy), and the mesic zone was our least accurately predicted moisture zone 


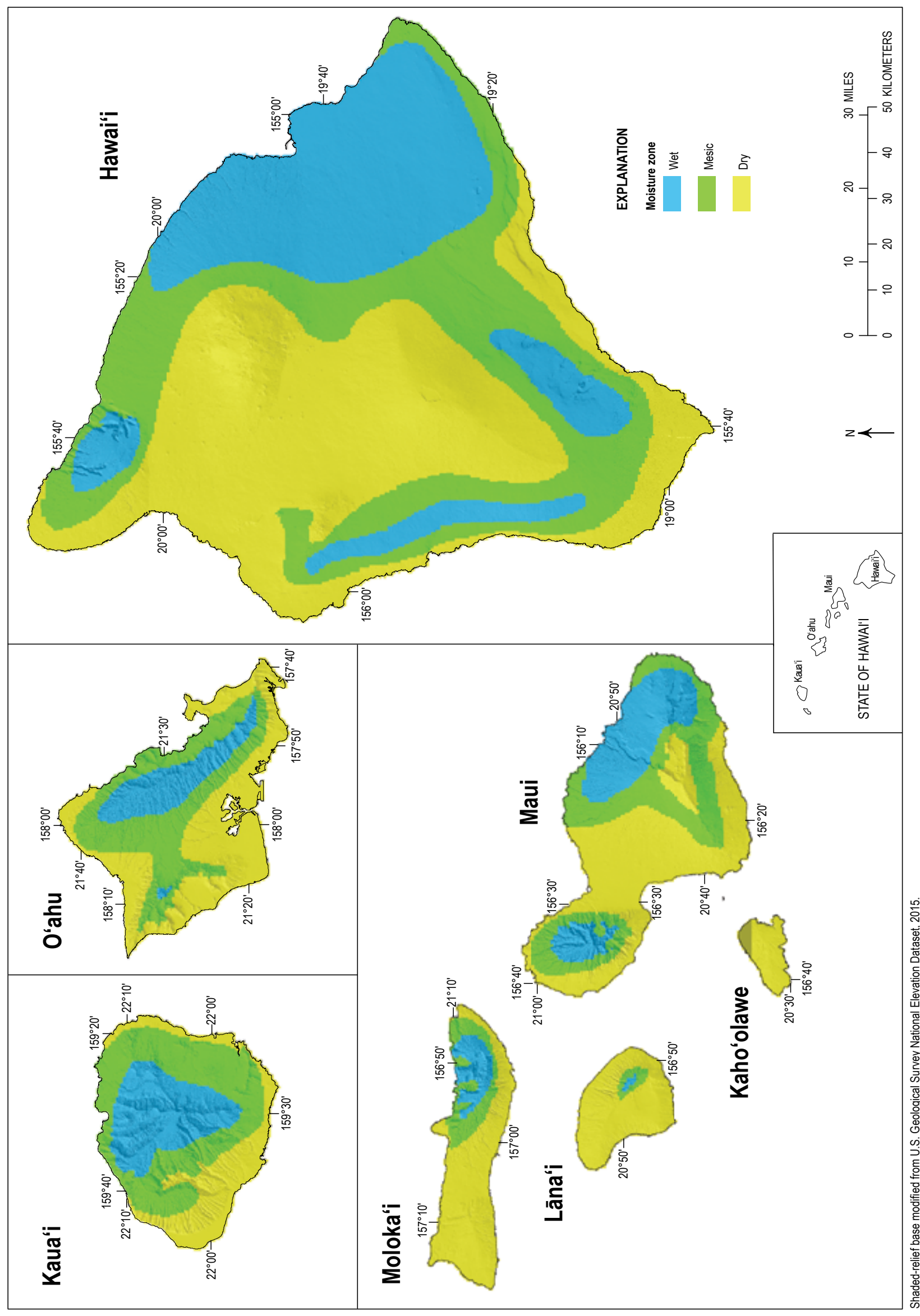


(0.899 accuracy). Although the general distribution of moisture zones across all islands was well replicated by our model, in a few small areas our model had difficulties in properly representing the extent of certain moisture-zone features. For instance, our model tended to underestimate the extent of moist areas on the top of the Waianae range on the island of $\mathrm{O}^{\prime}$ ahu and the mesic areas on the top of the island of Lāna'i (fig. 3.5). As expected, our ensemble committee agreement shows transition zones between moisture zones as areas of greater uncertainty in our current projections, but owing to the high accuracy of our models these areas are generally small (fig. 3.6). Additionally, several areas across the Island of Hawai' $i$ also have relatively low within-model agreement, indicating greater uncertainties in our projections. Because of the high overall model accuracy, the uncalibrated current projections showed very small differences in prevalence among moisture zones when compared to the original basemap (table 3.2). Fortunately, our model calibration algorithm was able to reduce these small biases by adding small calibration constants $(<5$ percent adjustments) without any change in the overall classification accuracy. In preliminary models where biases in projections were larger, the calibration routine effectively removed bias and consequently raised model accuracies.

\subsubsection{Future Moisture-Zone Projections Across the Archipelago and Individual Islands}

Our future moisture-zone projection shows the suitability of the Hawaiian landscape to moisture zones by the end of the century (fig. 3.7). Our model-agreement map for future projections shows the uncertainty in projections is also concentrated in ecotones (fig. 3.8). Differences between figures 3.3 and 3.5 highlight areas that, by the end of the century, are projected to become more climatically suitable to a moisture zone other than the one present today. In quantitative terms, the extent of mesic areas across the archipelago is projected to decrease by 32 percent, with smaller extent increases for both dry and wet habitats (table 3.3). Although the decrease in the extent of mesic areas is large, this value hides an even greater underlying shift in distribution of mesic forest areas across the state where, by the end of the century, only 45 percent of current mesic areas are projected to remain in mesic conditions. This difference between mesic-extent change and projected areas remaining in mesic conditions is due to some of the loss in current mesic areas being counterbalanced by transition into mesic conditions in some other areas by the end of the century (table 3.4).

Table 3.2. Comparison of actual and modeled baseline moisture-zone prevalence as a proportion of total land area across the seven main Hawaiian Islands.

\begin{tabular}{lccc}
\hline Moisture & Actual baseline & \multicolumn{2}{c}{ Predicted baseline prevalence: } \\
\cline { 3 - 4 } zone & prevalence & Uncalibrated model & Calibrated model \\
\hline Dry & 0.451 & 0.446 & 0.449 \\
Mesic & 0.292 & 0.300 & 0.295 \\
Wet & 0.256 & 0.255 & 0.256 \\
\hline
\end{tabular}

Table 3.3. Summary of projected shifts in moisture-zone extent and prevalence between current and projected future conditions.

\begin{tabular}{lcccccc}
\hline $\begin{array}{c}\text { Moisture } \\
\text { zone }\end{array}$ & $\begin{array}{c}\text { Current } \\
\text { area }\left(\mathbf{k m}^{2}\right)\end{array}$ & $\begin{array}{c}\text { Projected future } \\
\text { area }\left(\mathbf{k m}^{2}\right)\end{array}$ & $\begin{array}{c}\text { Current proportion } \\
\text { of land area }\end{array}$ & $\begin{array}{c}\text { Projected future proportion } \\
\text { of land area }\end{array}$ & $\begin{array}{c}\text { Percent change } \\
\text { in total area }\end{array}$ & $\begin{array}{c}\text { Percent of current } \\
\text { area unchanged }\end{array}$ \\
\hline Dry & 7,290 & 8,440 & 0.449 & 0.52 & 15.78 & 88.9 \\
Mesic & 4,790 & 3,270 & 0.295 & 0.201 & -31.73 & 45.2 \\
Wet & 4,160 & 4,540 & 0.256 & 0.279 & 8.98 & 92.0 \\
\hline
\end{tabular}

Table 3.4. Transition matrix illustrating the amount of area shifting among moisture-zone classes between current and projected future conditions.

\begin{tabular}{lcccc}
\hline \multirow{2}{*}{ Future moisture zone } & \multicolumn{2}{c}{ Projected future area $\left(\mathbf{k m}^{2}\right)$ by source moisture zone } & \multirow{2}{*}{$\begin{array}{c}\text { Total projected future } \\
\text { area }\left(\mathbf{k m}^{2}\right)\end{array}$} \\
\cline { 2 - 4 } & Dry & Mesic & Wet & 32 \\
Dry & 6,483 & 1,925 & 303 & 8,440 \\
Mesic & 800 & 2,164 & 3,829 & 3,270 \\
Wet & 9 & 700 & 4,540 \\
\hline
\end{tabular}




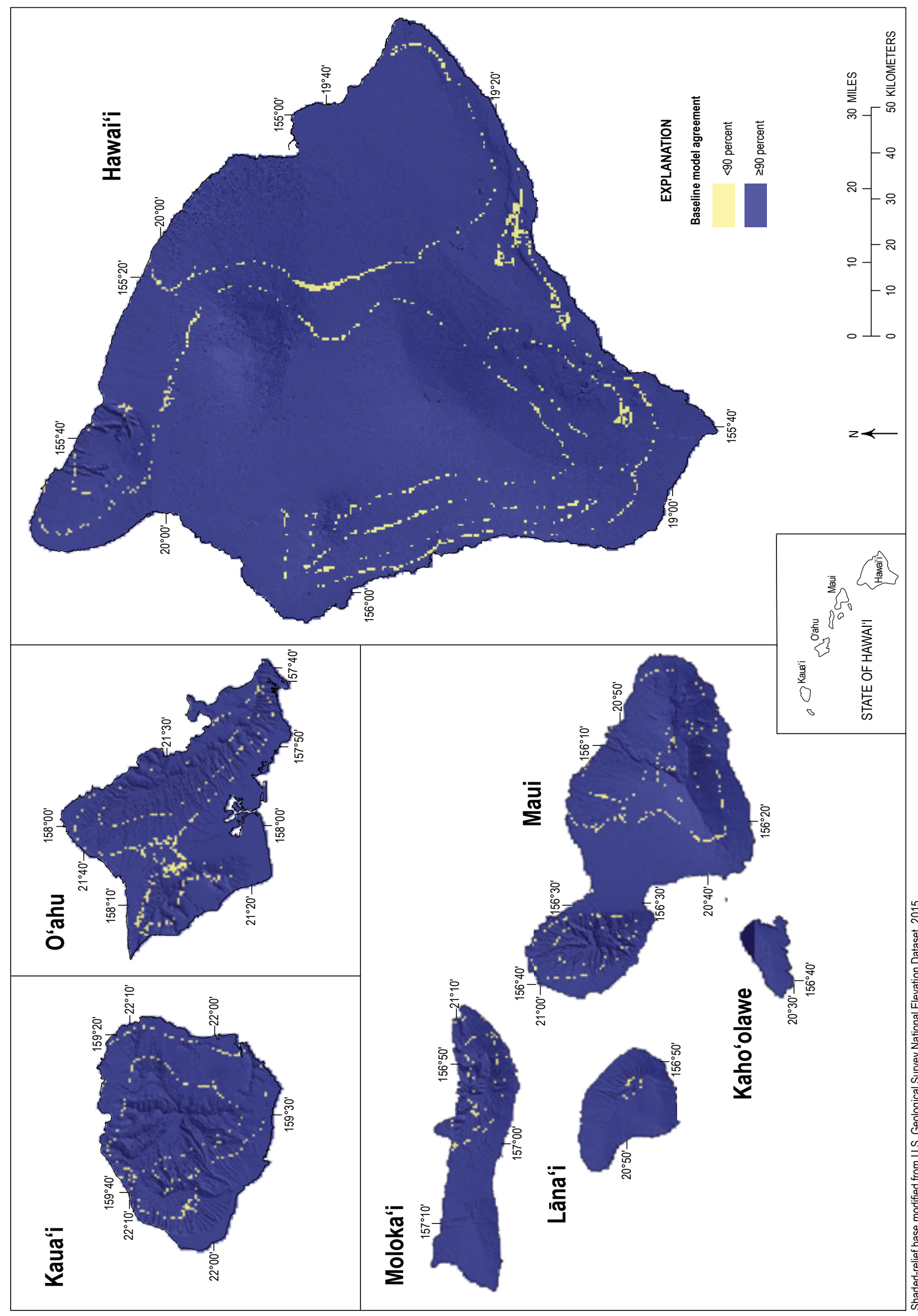

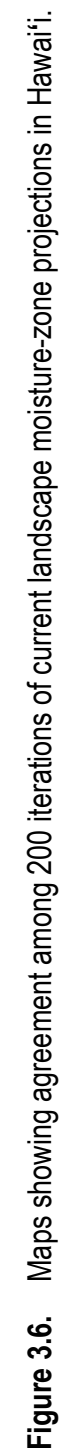




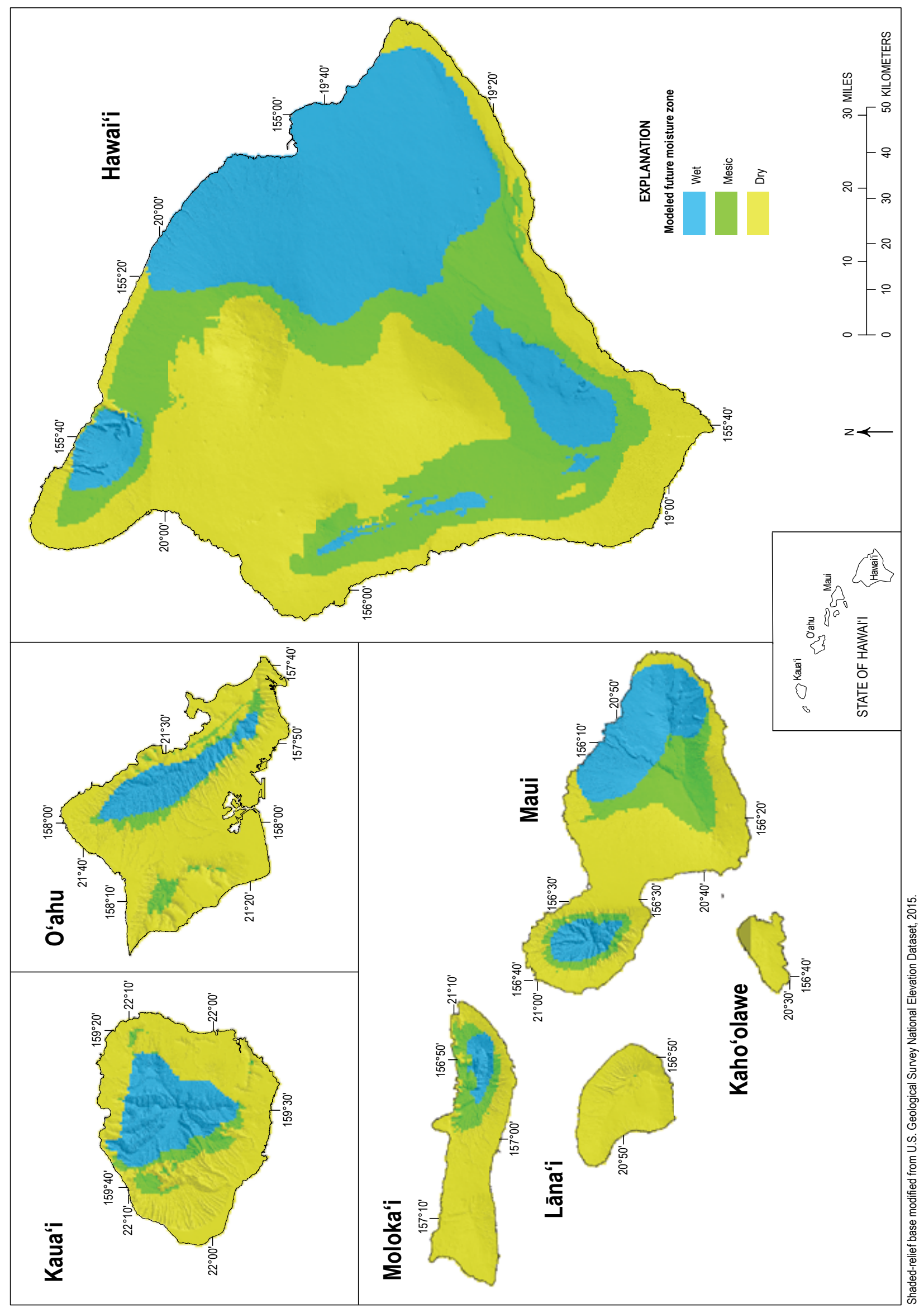

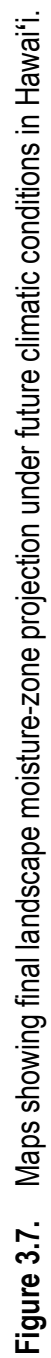




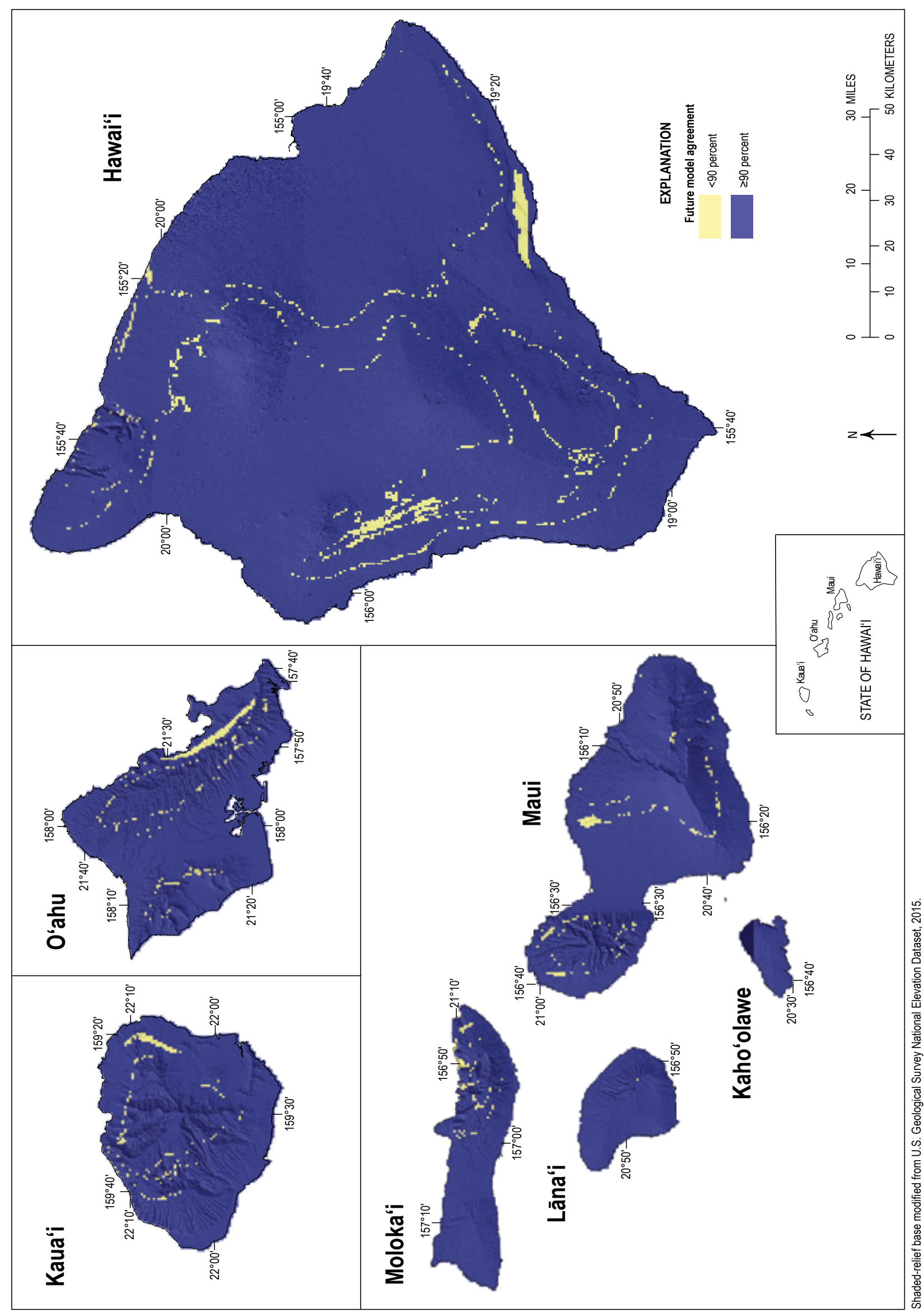

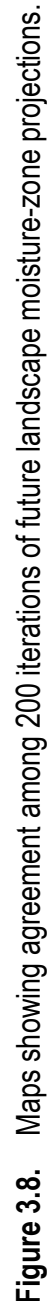




\subsubsection{Projected Moisture-Zone Shifts Across Islands}

The analysis of moisture-zone changes by individual island groups (Kaua'i, O'ahu, Maui Nui [the islands of Maui, Moloka'i, Lāna'i, and Kaho'olawe], and Hawai'i) shows considerable variability in projected change in the prevalence of the three moisture zones across islands (figs. 3.9, 3.10). In terms of changes in overall extent of moisture zones across islands (fig. 3.9), both $\mathrm{O}^{\prime}$ ahu and Kaua' $\mathrm{i}$ are projected to see large increases in the extent of dry moisture-zone areas ( $>50$ percent gain), with related large decreases in mesic moisture-zone areas ( $>75$ percent loss). However, this overall change in moisture-zone extent hides drastic changes in the distribution of the mesic moisture zone across the islands. The results summarizing the proportion of current moisture zones left unchanged between now and the end of the century show that nearly 50 percent of current mesic moisturezone areas on Maui and Hawai' $i$ Island by the end of the century become more suitable for dry or wet moisture zones (fig. 3.10). On Kaua' $\mathrm{i}$ and $\mathrm{O}^{\prime}$ ahu this shift is even more extreme, with less than 25 percent of current mesic moisture-zone areas persisting by the end of the century.

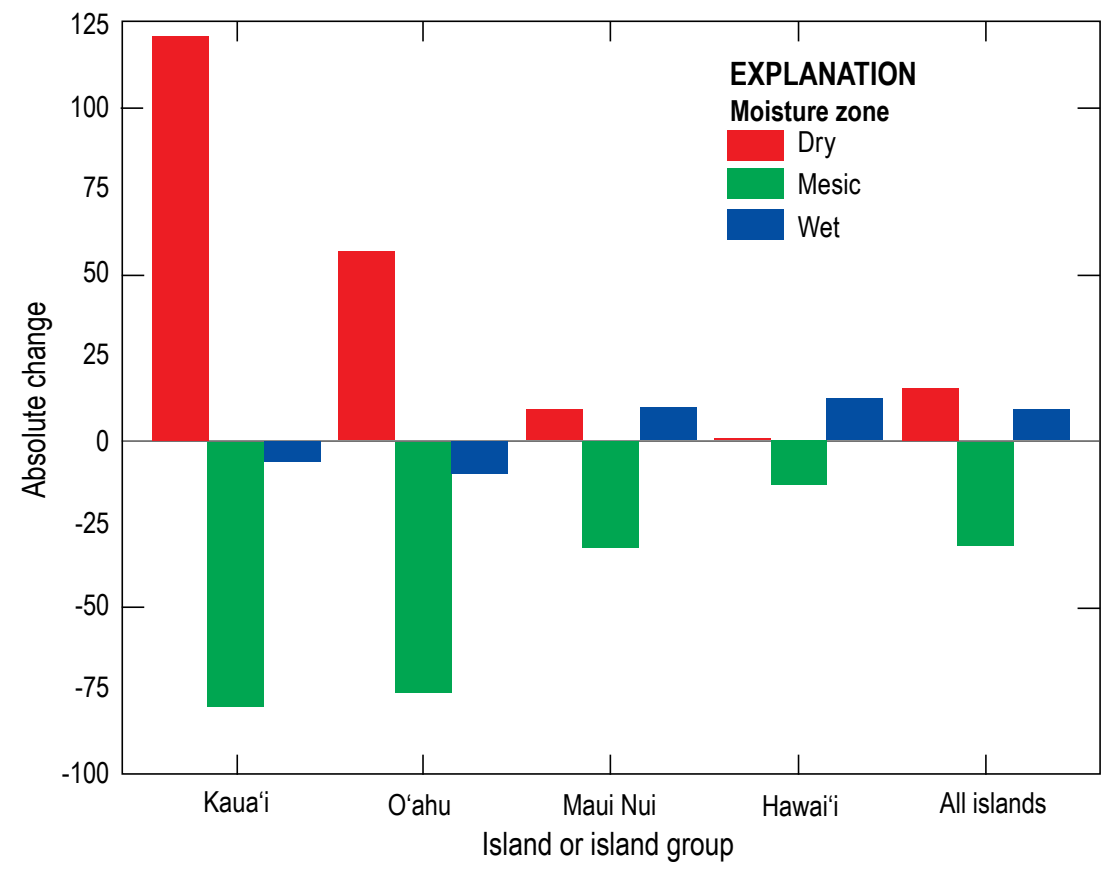

Figure 3.9. Plot of differences in projected proportional change in moisture-zone extent among islands. A value of 0 denotes no change in extent for a moisture zone. Maui Nui includes the islands of Maui, Moloka'i, Lāna'i, and Kaho'olawe.

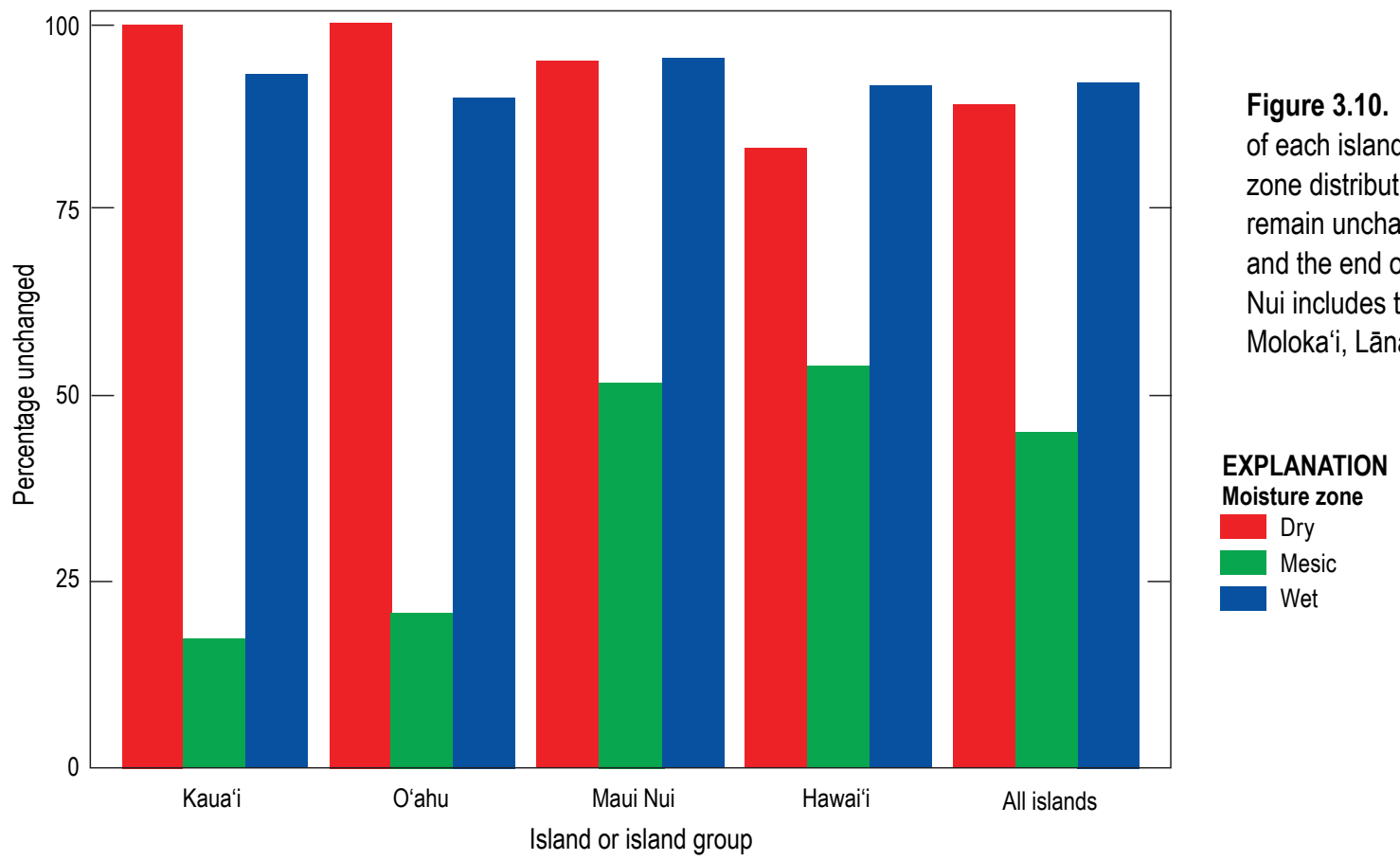




\subsubsection{Translating Moisture-Zone Shifts into Climate-Based Land-Cover Shifts}

In the context of broad cover types currently present across the Hawaiian chain, interesting patterns emerge in projected moisture-zone changes (figs. 3.11, 3.12). The loss of mesic areas and increase in dry areas across the archipelago happens primarily in areas currently forested, followed by smaller areas in grasslands. More specifically, the shift towards the dry moisture zone does is not manifested equally across the three vegetation classes (table 3.5 ). Nearly all mesic-moisture-zone loss within forested areas results from mesic forest switching to dry forest. Similarly, three quarters of the extent loss in mesic moisture zone within grasslands is attributed to a dry grassland expansion. However, the overall contraction of mesic moisture zones within shrubland areas, albeit small, is attributed to shifts towards wet shrubland vegetation. Looking at island differences for these shifts, the slight increase in extent of wet moisture-zone areas across the archipelago mostly happens in shrublands on the Island of Hawai'i (fig. 3.13).

\subsection{Discussion}

Based on the relatively high accuracy of our current model projections, the distribution of moisture zones across the landscape seems strongly related to average climatic conditions. This is partially expected, as moisture zones are clearly dependent on atmospheric climate (Price and others, 2012). The small number of classes and the coarse $(500-\mathrm{m})$ scale of analysis also likely helped with minimizing fine-scale variation that would otherwise not be easily explained by our simple correlative model. With these strong moisture-zone-climate relationships, we were able to recreate and project the Hawaiian moisture zones using climatic variables different from the information used to create the original moisture-zone maps and that are not available for future climate scenarios.
By applying our models to projected end-of-century climate conditions, we are able to provide a first approximation of how the distribution of moisture zones is likely to shift. Except for the large contraction of the wet moisture zone on the west side of Hawai'i Island, wet moisture zones are projected to remain relatively unchanged between now and the end of the century in both distribution and extent across the seven main Hawaiian Islands. This is also largely the case for current dry moisture zones except for some dry moisture-zone areas in Hawai' $i$ Island displaced by the upward movement of mesic moisture zones. The large contractions of mesic areas across the state follow an increasing pattern from Hawai' $i$ to Kaua' $i$, with most of these areas shifting towards drier moisture zones.

\subsubsection{Understanding Model Errors and Uncertainties}

Particularly noteworthy areas of consistent model error include small wet areas on top of O'ahu and Lāna'i known to be influenced by fog interception (Ekern, 1964). Indeed, these areas of model discrepancy may be useful to identify locations where factors beyond those directly related to temperature and precipitation may drive differences in plant-available moisture across the archipelago. For instance, relative humidity has been shown to be a strong determinant of tree-line position at higher elevations on Maui (Crausbay and others, 2014). Substrate age and other non-climatic factors may also be important to explain other model discrepancies and patterns at finer spatial scales (Price and others, 2012).

Although our model replicates the pattern of potential moisture-zone distribution across the Hawaiian landscape well, it is still worthwhile to explore the reasons for discrepancies between the model and our original baseline moisture-zone map. First, our approach requires a relevant set of environmental predictors. Although we assessed multiple possible combinations of climatic indicators commonly used in similar analyses, these bioclimatic variables are entirely based on precipitation and temperature and do not account for climate extremes that may be important

Table 3.5. Summary of projected shifts in land-cover class based on integrating moisture-zone shifts with current distribution of forest, shrubland, and grassland areas.

\begin{tabular}{lcccc}
\hline \multicolumn{1}{c}{ Land-cover class } & $\begin{array}{c}\text { Current percent of land } \\
\text { area }\end{array}$ & $\begin{array}{c}\text { Projected future percent } \\
\text { of land area }\end{array}$ & $\begin{array}{c}\text { Percent change from } \\
\text { current }\end{array}$ & $\begin{array}{c}\text { Percent unchanged } \\
\text { from current }\end{array}$ \\
\hline Dry forest & 5.1 & 9.8 & 94.3 & 92.5 \\
\hline Mesic forest & 11.6 & 6.3 & -45.4 & 41.0 \\
\hline Wet forest & 18.8 & 19.3 & 2.7 & 92.8 \\
Dry shrubland & 8.8 & 9.0 & 2.4 & 85.4 \\
Mesic shrubland & 5.4 & 4.3 & -20.3 & 53.5 \\
\hline Wet shrubland & 2.4 & 3.2 & 37.0 & 93.0 \\
\hline Dry grassland & 9.0 & 10.6 & 17.6 & 93.1 \\
Mesic grassland & 6.4 & 4.4 & -31.7 & 51.9 \\
Wet grassland & 1.5 & 2.0 & 30.5 & 71.0 \\
\hline
\end{tabular}




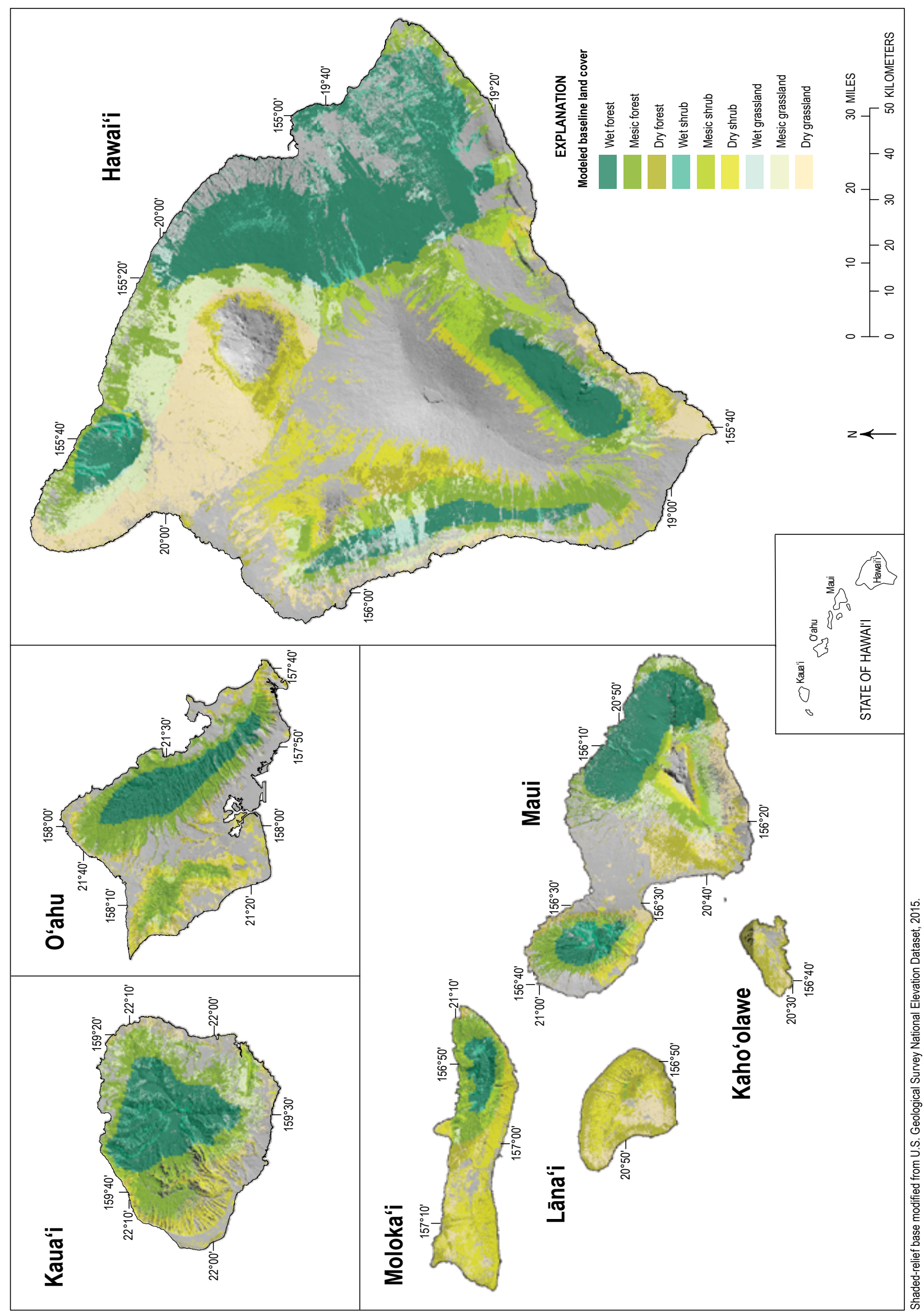

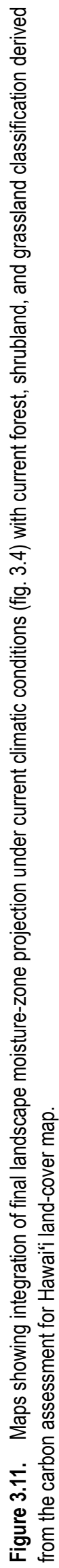



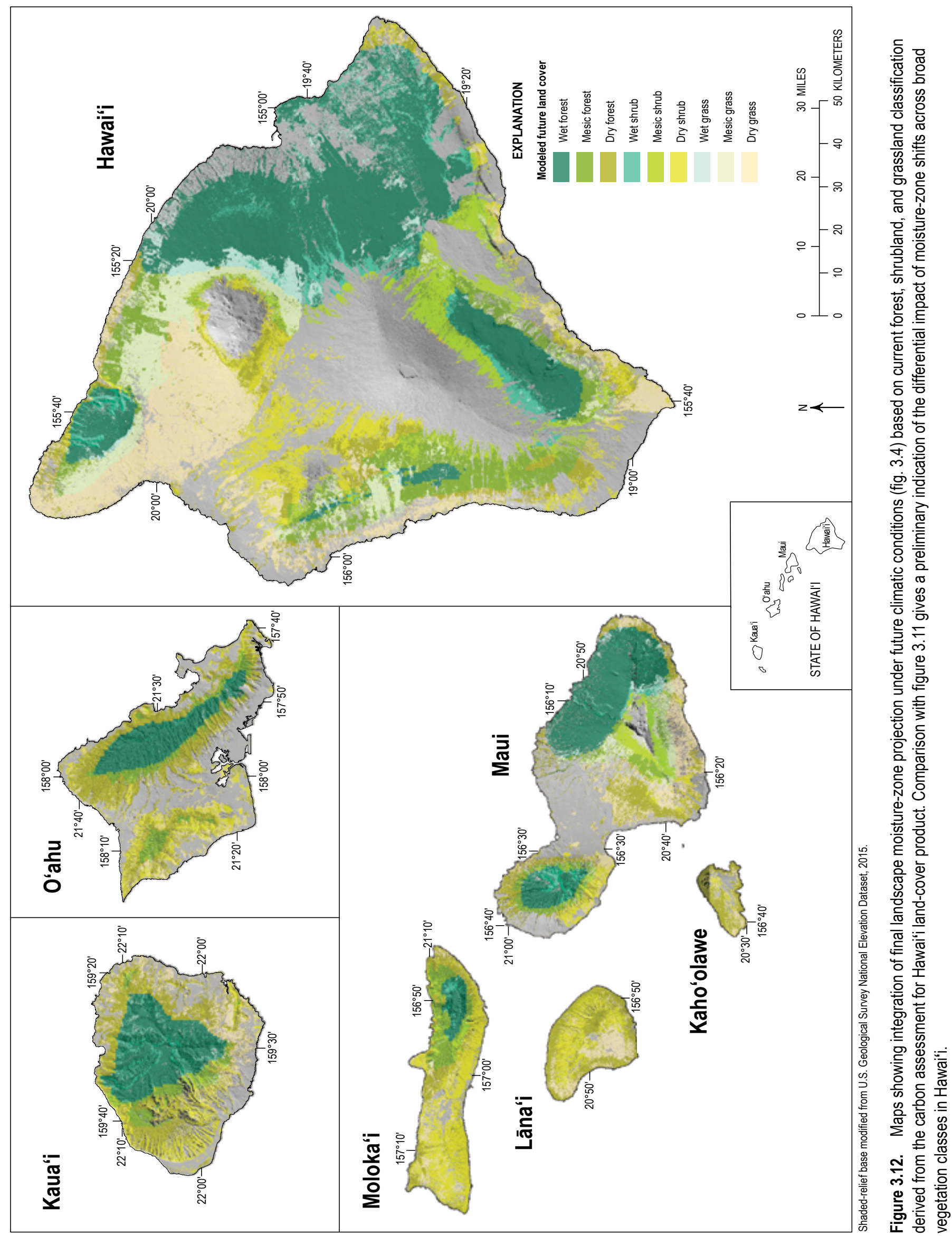


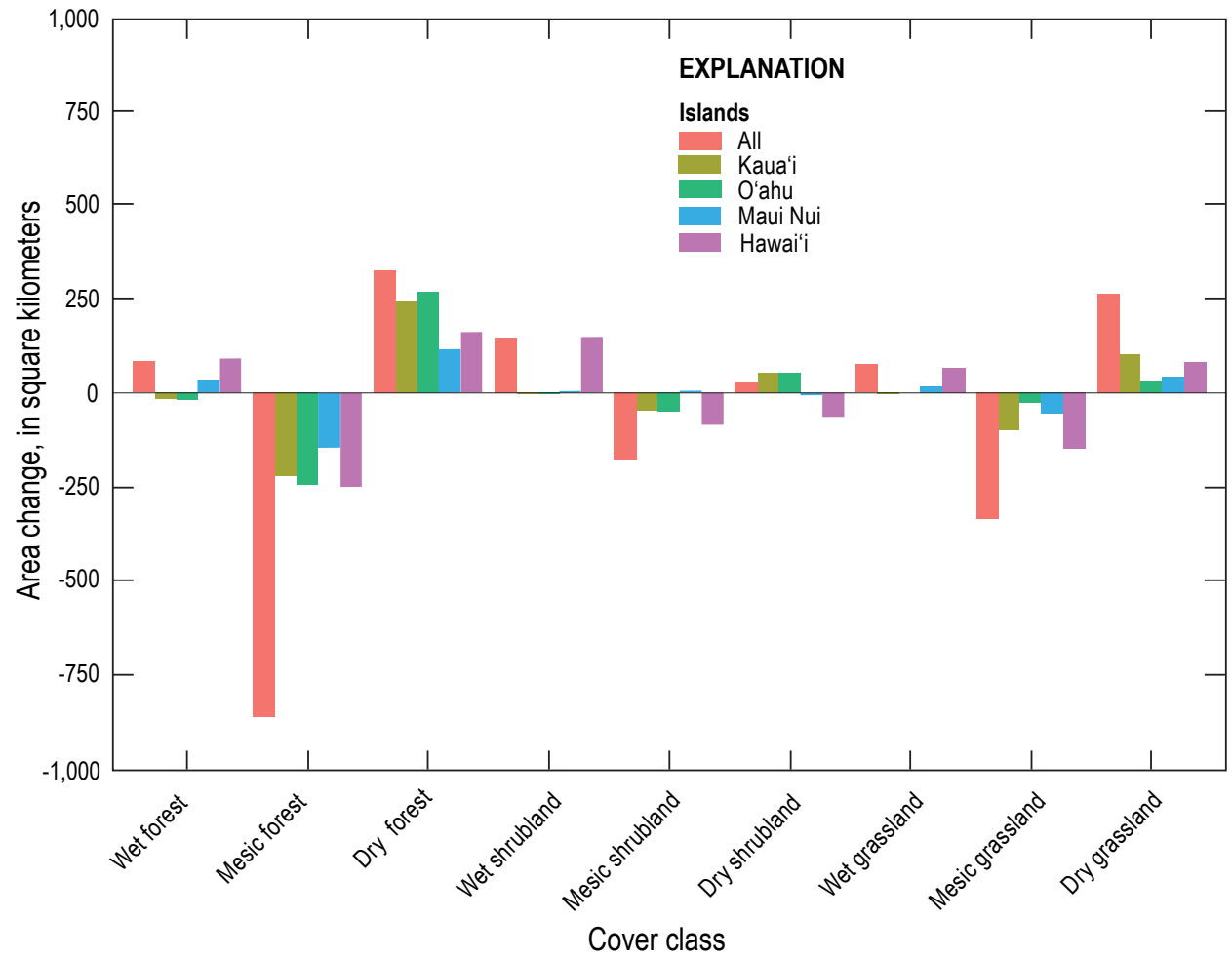

Figure 3.13. Plot of projected area change in moisture-zone extent among broad island vegetation classes. Maui Nui includes the islands of Maui, Moloka'i, Lāna'i, and Kaho'olawe.

in defining landscape vegetation patterns (Crausbay and others, 2014). For example, cloud cover, potential evapotranspiration, and fog deposition are all additional variables that may be important in better defining the distribution of Hawaiian moisture zones; however, these variables are notoriously difficult to estimate for the current climate and even harder to adequately project into the future (Hawkins and Sutton, 2011; Knutti and Sedláček, 2013). Another source of model errors may be inaccuracies in the moisture-zone data used. Indeed, the moisture-zone map is partially based on past archipelago maps of mean annual precipitation (Giambelluca and others, 1986) that are known to have discrepancies when compared to more recent estimates (Giambelluca and others, 2013). Nevertheless, we expect errors in the baseline moisture-zone map to be relatively small given the coarse scale of our analysis.

Regarding future projection uncertainties, our ensemble committee-agreement map (that represents an estimate of model agreement among multiple iterations) only encapsulates a portion of the uncertainty inherent in future projections. Future expansion of this analysis with additional climate projection scenarios, as they are made available, will likely show a much more complete picture of future projection uncertainty. Nevertheless, preliminary analyses using alternative modeling approaches and alternative baselines yielded consistent trends of increases in dry and wet areas at the expense of mesic areas. This indicates that projection uncertainty owing to model choice and starting conditions is not unacceptably large.

\subsubsection{Projected Moisture-Zone Shifts in the Context of Hawailan Climate Trends}

In general, the projected moisture-zone shifts follow broad patterns of current and projected climate trends. Projected precipitation shifts are generally expected to make wet areas wetter and dry areas drier, both at the global and regional level (Zhang and others, 2012; Collins and others, 2013). However, examining the differences among islands shows that patterns in our moisture-zone projections are slightly more complex. Namely, expansion of the wet moisture zone occurs on windward (wet) Hawai'i and Maui but not on O'ahu or Kaua'i. Conversely, expansion of the dry moisture zone occurs on the leeward (dry) side of every island except Hawai' $i$. This larger expansion of the dry moisture zones at the northwestern end of the archipelago matches coarse global future projections of precipitation change (Keener and others, 2012). These projected drying trends also occur in the context of recent decreases in streamflow (Bassiouni and Oki, 2013) and precipitation (Chu and Chen, 2005; Krushelnycky and others, 2013).

One major uncertainty in our moisture-zone-shift projections is the high-elevation areas on Maui and Hawai' $i$ influenced by the trade-wind inversion. The frequency and intensity of the trade-wind inversion is known to raise temperatures and cap cloud formation in areas above $2,000 \mathrm{~m}$ in elevation, and hence raise insolation and decrease precipitation and relative humidity (Cao and others, 2007). This feature of Hawaiian climate has a major impact on the distribution of 
vegetation at higher elevations, effectively limiting the height of the forest line on these islands (Kitayama and MuellerDombois, 1992; Loope and Giambelluca, 1998). Until recently, there has been considerable debate about the response of tradewind inversions to regional and global climate shifts (Still and others, 1999; Sperling and others, 2004), but global and regional analysis increasingly point to a likely increase in frequency of the trade-wind inversion that would lead to persistently drier conditions (Lauer and others, 2013; Crausbay and others, 2014).

Although the HRCM simulations replicate the patterns of increased temperature and decreased precipitation in areas above the trade-wind inversion (Zhang and others, 2012), contrary to expected changes in the trade-wind inversion from other analyses, HRCM future projections seem to include a more varied pattern of precipitation change for areas above the trade-wind inversion including areas with more, less, or equal precipitation. This makes some of the projected spread of the wet moisture zone in high-elevation windward Maui and Hawai' $i$ and the conversion of the top of Maui from dry to mesic likely optimistic.

\subsubsection{Temperature-Induced Drought and Vegetation Change}

The general increase in dry areas and decrease in mesic areas between present and the end of the century occur in areas that suggest some of these trends will be driven by expected temperature increases. In fact, there is ample research that documents temperature amplification of plant stress and drought (Kolb and Robberecht, 1996; Barber and others, 2000; Park Williams and others, 2013) through greater evapotranspirative demand (Weiss and others, 2009). Recent research has shown that temperature is a strong driver of drought conditions across the southwestern United States including in temperate forests (Barber and others, 2000; Park Williams and others, 2013). Many other studies further highlight the importance of temperature to drought impacts in terms of mortality, stress, and overall vegetation change (Adams and others, 2009; Weiss and others, 2009; Allen and others, 2010; McDowell and others, 2011).

\subsubsection{Implications of Projected Vegetation Change to Hawaiian Conservation Efforts}

The generally large projected decreases in mesic areas across the state and especially on the islands of Kaua' $i$ and $\mathrm{O}^{\prime}$ ahu, have potentially large implications relative to conservation of highly valuable native-species habitat. Mesic habitats in Hawai' $i$ are zones of high species diversity because they contain elements from both wet and dry habitats (Gagne and Cuddihy, 1990; Price, 2004; Gon, 2006). However, because this moisture zone is optimal for timber production, agriculture, and ranching, large parts of this habitat have been altered from their natural condition, resulting in a loss of native-species diversity.

The reduction in extent of the mesic zone is directly linked to an increase in the future extent of dry habitat. Although the original Hawaiian dry-plant communities were also known to harbor a great diversity of plant species, particularly woody taxa (Rock, 1913; Gagne and Cuddihy, 1990), much of this habitat zone, particularly below 1,000-m elevation, has already been substantially altered by human land use, invasive species, and fire. An expansion of the area of dry habitat will likely result in an increase in areas impacted by fire, which are then quickly colonized by invasive grass species, and the likelihood of more fires further increases. When a fire starts in a dry habitat, it can easily spread into the adjacent mesic habitats and cause substantial damage to the species composition and vegetation structure of that community. Beyond the broad categorical projected shift of mesic areas to dry areas, most of the existing native dry communities are on the wetter end of the dry moisture zone range, which suggests impacts of projected climate shifts within stable moisture-zone areas may also be significant.

Besides the significant pattern of mesic-to-dry moisturezone switch projected in our models, one other projected change with clear conservation implication is the likelihood of the nearly complete loss of the wet forest habitat on the western side of the Island of Hawai' 1 . Although the reduction of the wet forest in this area is spatially compensated by projected wet zone expansion at higher elevation windward areas on Hawai' $i$ Island, the native plant species adapted to the wet habitat in the Kona area (for example, Cyanea marksii and Cyrtandra menziesii) will likely be lost (Price, 2004).

Our newly designed approach opens the door to several improvements to vegetation and habitat modeling in Hawai' $i$ and elsewhere. We are currently refining our modeling approach to consider differences in limiting factors to the distribution of individual vegetation classes. We are also exploring modeling improvements that would allow for the consideration of finer vegetation classes that are more easily relatable to on-the-ground management efforts. With these and other improvements, we can use our models as a steppingstone to develop mechanistic models for the region that can provide a wealth of information on the processes that drive the projected shifts our analysis identifies.

Nevertheless, our projections can still be used to characterize coarse vegetation changes and the long-term consequences to carbon storage across the landscape. To do so, the integration of our projections with multiple fire, landscapemanagement, and use scenarios, along with the assessment of aboveground and belowground carbon storage will provide an unprecedented detail of carbon stocks across the Hawaiian landscape and the potential future shifts. As such, our results are used in Sleeter and others (this volume, chap. 8) to refine land-use and land-cover scenarios for the archipelago and project terrestrial carbon storage and $\mathrm{CO}_{2}$ fluxes. 


\subsection{References Cited}

Adams, H.D., Guardiola-Claramonte, M., Barron-Gafford, G.A., Villegas, J.C., Breshears, D.D., Zou, C.B., Troch, P.A., and Huxman, T.E., 2009, Temperature sensitivity of drought-induced tree mortality portends increased regional die-off under global-change-type drought: Proceedings of the National Academy of Sciences, v. 106, no. 17, p. 7063-7066.

Allen, C.D., Macalady, A.K., Chenchouni, H., Bachelet, D., McDowell, N., Vennetier, M., Kitzberger, T., Rigling, A., Breshears, D.D., Hogg, E.H., Gonzalez, P., Fensham, R., Zhang, Z., Castro, J., Demidova, N., Lim, J.-H., Allard, G., Running, S.W., Semerci, A., and Cobb, N., 2010, A global overview of drought and heat-induced tree mortality reveals emerging climate change risks for forests: Forest Ecology and Management, v. 259, no. 4, p. 660-684, available at http:// dx.doi.org/10.1016/j.foreco.2009.09.001.

Asner, G.P., Elmore, A.J., Hughes, R.F., Warner, A.S., Vitousek, P.M., 2005, Ecosystem structure along bioclimatic gradients in Hawai'i from imaging spectroscopy: Remote Sensing of Environment, v. 96, p. 497-508.

Asner, G.P., Hughes, R.F., Varga, T.A., Knapp, D.E., and Kennedy-Bowdoin, T., 2009, Environmental and biotic controls over aboveground biomass throughout a tropical rain forest: Ecosystems, v. 12, no. 2, p. 261-278, available at http:// dx.doi.org/10.1007/s10021-008-9221-5.

Asner, G.P., Hughes, R.F., Mascaro, J., Uowolo, A.L., Knapp, D.E., Jacobson, James, Kennedy-Bowdoin, T., and Clark, J.K., 2011, High-resolution carbon mapping on the millionhectare Island of Hawaii: Frontiers in Ecology and the Environment, v. 9, no. 8, p. 434-439, available at http://dx.doi. org/10.1890/100179.

Asner, G.P., Hughes, R.F., Vitousek, P.M., Knapp, D.E., Kennedy-Bowdoin, T., Boardman, J., Martin, R.E., Eastwood, M., and Green, R.O., 2008, Invasive plants transform the three-dimensional structure of rain forests: Proceedings of the National Academy of Sciences, v. 105, no. 11, p. 4519-4523.

Bachelet, D., Neilson, R.P., Lenihan, J.M., and Drapek, R.J., 2001, Climate change effects on vegetation distribution and carbon budget in the United States: Ecosystems, v. 4, no. 3, p. $164-185$.

Barber, V.A., Juday, G.P., and Finney, B.P., 2000, Reduced growth of Alaskan white spruce in the twentieth century from temperature-induced drought stress: Nature, v. 405, p. 668-673.

Bassiouni, M., and Oki, D.S., 2013, Trends and shifts in streamflow in Hawai ${ }^{\circ}$ i, 1913-2008: Hydrologic Processes, v. 27 , no. 10 , p. $1484-1500$, available at $\mathrm{http}: / / \mathrm{dx}$.doi. org/10.1002/hyp.9298.
Beniston, M., Diaz, H.F., and Bradley, R.S., 1997, Climatic change at high elevation sites - an overview: Climate Change, v. 36, no. 3, p. 233-251.

Benoit, J.W., Fujioka, F.M., and Weise, D.R., 2009, Modeling fire behavior on tropical islands with high-resolution weather data, in González-Cabán, A., ed., Proceedings of the Third International Symposium on Fire Economics, Planning, and Policy — Common Problems and Approaches: Albany, Calif., U.S. Department of Agriculture, Forest Service, Pacific Southwest Research Station General Technical Report PSWGTR-227, p. 321-330.

Bonan, G.B., Levis, S., Sitch, S., Vertenstein, M., and Oleson, K.W., 2003, A dynamic global vegetation model for use with climate models - concepts and description of simulated vegetation dynamics: Global Change Biology, v. 9, no. 11, p. $1543-1566$.

Cao, G., Giambelluca, T.W., Stevens, D.E., and Schroeder, T.A., 2007, Inversion variability in the Hawaiian trade wind regime: Journal of Climate, v. 20, no. 7, p. 1145-1160.

Chu, P.-S., and Chen, H., 2005, Interannual and interdecadal rainfall variations in the Hawaiian islands: Journal of Climate, v. 18, no. 22, p. 4796-4813.

Collins, M., Knutti, R., Arblaster, J., Dufresne, J.-L., Fichefet, T., Friedlingstein, P., Gao, X., Gutowski, W.J., Jr., Johns, T., Krinner, G., Shongwe, M., Tebaldi, C., Weaver, A.J., and Wehner, M., 2013, Long-term climate change-Projections, commitments and irreversibility, in Stocker, T.F., Qin, D., Plattner, G.-K., Tignor, M.M.B., Allen, S.K., Boschung, J., Nauels, A., Xia, Y., Bex, V., Midgley, P.M., eds., Climate change 2013 The physical science basis - Contribution of Working Group I to the Fifth Assessment Report of the Intergovernmental Panel on Climate Change: Cambridge, U.K., Cambridge University Press, 108 p.

Cramer, W., Bondeau, A., Woodward, F.I., Prentice, I.C., Betts, R.A., Brovkin, V., Cox, P.M., Fisher, V., Foley, J.A., Friend, A.D., Kucharik, C., Lomas, M.R., Ramankutty, N., Sitch, S., Smith, B., White, A., and Young-Molling, C., 2001, Global response of terrestrial ecosystem structure and function to $\mathrm{CO}_{2}$ and climate change-results from six dynamic global vegetation models: Global Change Biology, v. 7 , no. 4 , p. 357-373.

Crausbay, S.D., Frazier, A.G., Giambelluca, T.W., Longman, R.J., and Hotchkiss, S.C., 2014, Moisture status during a strong El Niño explains a tropical montane cloud forest's upper limit: Oecologia, v. 175, no. 1, p. 273-284, available at https://dx.doi.org/10.1007/s00442-014-2888-8.

Diaz, H.F., and Bradley, R.S., 1997, Temperature variations during the last century at high elevation sites: Climatic Change, v. 36 , no. 3, p. 253-279. 
Ekern, P.C., 1964, Direct interception of cloud water on Lanaihale, Hawaii: Journal of the Soil Science Society of America, v. 28, no. 3, p. 419-421.

Elith, J., Leathwick, J.R., and Hastie, T., 2008, A working guide to boosted regression trees: Journal of Animal Ecology, v. 77, no. 4, p. 802-813.

Ellsworth, L.M., Litton, C.M., Taylor, A.D., and Kauffman, J.B., 2013, Spatial and temporal variability of guinea grass (Megathyrsus maximus) fuel loads and moisture on Oahu, Hawaii: International Journal of Wildland Fire, v. 22, no. 8, p. 1083-1092, available at http://dx.doi.org/10.1071/WF12051.

Fortini, L., Price, J., Jacobi, J., Vorsino, A., Burgett, J., Brinck, K., Amidon, F., Miller, S., Gon, S., III, Koob, G., and Paxton, E., 2013, A landscape-based assessment of climate change vulnerability for all native Hawaiian plants: University of Hawai' $i$ at Hilo, Hawai'i Cooperative Studies Unit Technical Report HCSU-044, 134 p., available at http://hdl.handle. net/10790/2620.

Fortini, L.B., Vorsino, A.E., Amidon, F.A., Paxton, E.H., and Jacobi, J.D., 2015, Large-scale range collapse of Hawaiian forest birds under climate change and the need for 21 st century conservation options: PLoS ONE, v. 10, no. 10, 22 p., available at http://dx.doi.org/10.1371/journal.pone.0140389.

Gagne, W.C., and Cuddihy, L.W., 1990, Vegetation, in Wagner, W.L., Herbst, D.R., and Sohmer, S.H., 1999, Manual of the Flowering Plants of Hawai' $i$ ( 2 d ed.): Honolulu, University of Hawai'i Press, Bishop Museum Press, p. 45-114.

Giambelluca, T.W., Chen, Q., Frazier, A.G., Price, J.P., Chen, Y.-L., Chu, P.-S., Eischeid, J.K., and Delparte, D.M., 2013, Online Rainfall Atlas of Hawai' $i$ : Bulletin of the American Meteorological Society, v. 94, p. 313-316. (Available at http:// rainfall.geography.hawaii.edu.)

Giambelluca, T.W., Nullet, M.A., and Schroeder, T.A., 1986, Rainfall atlas of Hawai' $i$ : Honolulu, Hawai' $i$ Department of Land and Natural Resources, Division of Water and Land Development Report R76, 267 p.

Giambelluca, T.W., Shuai, X., Barnes, M.L., Alliss, R.J., Longman, R.J., Miura, T., Chen, Q., Frazier, A.G., Mudd, R.G., Cuo, L., and Businger, A.D., 2014, Evapotranspiration of Hawai'i: final report to the U.S. Army Corps of EngineersHonolulu District and the Commission on Water Resource Management, State of Hawai'i, 178 p., available at http:// evapotranspiration.geography.hawaii.edu.

Gibbs, H., 2007, Monitoring and estimating tropical forest carbon stocks - making REDD a reality: Environmental Research Letters, v. 2, no. 4, 13 p.
Gon, S.M., III, Allison, A., Cannarella, R.J., Jacobi, J.D., Kaneshiro, K.Y., Kido, M.H., Lane-Kamahele, M., and Miller, S.E., 2006, A GAP analysis of Hawaii_-Final Report: U.S. Geological Survey, Research Corporation of the University of Hawai'i, 163 p., plus maps and appendixes.

Gonzalez, P., Neilson, R.P., Lenihan, J.M., and Drapek, R.J., 2010, Global patterns in the vulnerability of ecosystems to vegetation shifts due to climate change: Global Ecology Biogeography, v. 19, no. 6, p. 755-768, available at http://dx.doi.org/10.1111/ j.1466-8238.2010.00558.x.

Hartig, F., Dyke, J., Hickler, T., Higgins, S.I., O’Hara, R.B., Scheiter, S., and Huth, A., 2012, Connecting dynamic vegetation models to data - an inverse perspective: Journal of Biogeography, v. 39, no. 12, p. 2240-2252, available at http://dx.doi.org/10.1111/j.1365-2699.2012.02745.x.

Hastie, T., Tibshirani, R., and Friedman, J., 2011, The Elements of Statistical Learning - Data Mining, Inference, and Prediction ( $2 \mathrm{~d}$ ed.): New York, Springer.

Hawkins, E., and Sutton, R., 2011, The potential to narrow uncertainty in projections of regional precipitation change: Climate Dynamics, v. 37, no. 1, p. 407-418, available at http://dx.doi.org/10.1007/s00382-010-0810-6.

Hijmans, R., Phillips, S., Leathwick, J., and Elith, J., 2012, Dismo-Species distribution modeling: Comprehensive R Archive Network, https://cran.r-project.org.

Hijmans, R.J., van Etten, J., Mattiuzzi, M., Sumner, M., Greenberg, J.A., Lamigueiro, O.P., Bevan, A., Racine, E.B., and Shortridge, A., 2014, Raster-Geographic data analysis and modeling: Comprehensive R Archive Network, https://cran.rproject.org.

Jacobi, J.D., 1989, Vegetation maps of the upland plant communities on the islands of Hawai' $i$, Maui, Moloka' $i$, and Lana'i: University of Hawai'i at Mānoa, Cooperative National Park Resources Studies Unit Technical Report 68, 25 p.

Jiménez-Valverde, A., and Lobo, J.M., 2007, Threshold criteria for conversion of probability of species presence to either-or presence-absence: Acta Oecologica, v. 31, no. 3, p. 361-369.

Keener, V.W., Marra, J.J., Finucane, M.L., Spooner, D., and Smith, M.H., eds., 2012, Climate change and Pacific Islands; indicators and impacts - Report for the 2012 Pacific Islands regional climate assessment (PIRCA): Washington, D.C., Island Press, $170 \mathrm{p}$.

Kitayama, K., and Mueller-Dombois, D., 1992, Vegetation of the wet windward slope of Haleakala, Maui, Hawaii: Pacific Science, v. 46, no. 2, p. 197-220. [Accessed March 3, 2015 at http://scholarspace.manoa.hawaii.edu/handle/10125/722.] 
Knutti, R., and Sedláček, J., 2013, Robustness and uncertainties in the new CMIP5 climate model projections: Nature Climate Change, v. 3, no. 4, p. 369-373, available at http://dx.doi.org/10.1038/nclimate1716.

Kolb, P.F., and Robberecht, R., 1996, High temperature and drought stress effects on survival of Pinus ponderosa seedlings: Tree Physiology, v. 16, no. 8, p. 665-672.

Krushelnycky, P.D., Loope, L.L., Giambelluca, T.W., Starr, F., Starr, K., Drake, D.R., Taylor, A.D., and Robichaux, R.H., 2013, Climate-associated population declines reverse recovery and threaten future of an iconic high-elevation plant: Global Change Biology, v. 19, no. 3, p. 911-922, available at http://dx.doi.org/10.1111/gcb.12111.

Lauer, A., Zhang, C., Elison-Timm, O., Wang, Y., and Hamilton, K., 2013, Downscaling of climate change in the Hawai' $i$ region using CMIP5 results - On the choice of the forcing fields: Journal of Climate, v. 26, no. 24, p. 6-10030, available at http://dx.doi.org/10.1175/JCLI-D-13-00126.1.

Liu, C., White, M., and Newell, G., 2011, Measuring and comparing the accuracy of species distribution models with presenceabsence data: Ecography, v. 34, no. 2, p. 232-243, available at http://dx.doi.org/10.1111/j.1600-0587.2010.06354.x.

Loope, L., and Giambelluca, T., 1998, Vulnerability of island tropical montane cloud forests to climate change, with special reference to East Maui, Hawaii: Climatic Change, v. 39 , no. 2 , p. $503-517$.

Lucht, W., Schaphoff, S., Erbrecht, T., Heyder, U., and Cramer, W., 2006, Terrestrial vegetation redistribution and carbon balance under climate change: Carbon Balance and Management, v. 1, no. 6, 7 p.

Mascaro, J., Becklund, K.K., Hughes, R.F., and Schnitzer, S.A., 2008, Limited native plant regeneration in novel, exotic-dominated forests on Hawai ${ }^{i}$ : Forest Ecology and Management, 256, no. 4, p. 593-606.

McDowell, N.G., Beerling, D.J., Breshears, D.D., Fisher, R.A., Raffa, K.F., and Stitt, M., 2011, The interdependence of mechanisms underlying climate-driven vegetation mortality: Trends in Ecology and Evolution, v. 26, no. 10, p. 523-532, available at http://dx.doi.org/10.1016/j. tree.2011.06.003.

Ostertag, R., Inman-Narahari, F., Cordell, S., Giardina, C.P., and Sack, L., 2014, Forest structure in low-diversity tropical forests-A study of Hawaiian wet and dry forests: PLoS ONE, v. 9, no. 8, 18 p., available at http://dx.doi. org/10.1371/journal.pone.0103268.
Park Williams, A., Allen, C.D., Macalady, A.K., Griffin, D., Woodhouse, C.A., Meko, D.M., Swetnam, T.W., Rauscher, S.A., Seager, R., Grissino-Mayer, H.D., Dean, J.S., Cook, E.R., Gangodagamage, C., Cai, M., and McDowell, N.G., 2013, Temperature as a potent driver of regional forest drought stress and tree mortality: Nature Climate Change, v. 3, p. 292-297, available at http://dx.doi.org/10.1038/ nclimate1693.

Pavlick, R., Drewry, D.T., Bohn, K., Reu, B., and Kleidon, A., 2013, The Jena Diversity-Dynamic Global Vegetation Model (JeDi-DGVM) - A diverse approach to representing terrestrial biogeography and biogeochemistry based on plant functional trade-offs: Biogeosciences, v. 10, no. 6, p. 4137-4177, available at http://dx.doi.org/10.5194/bg-104137-2013.

Price, J.P., 2004, Floristic biogeography of the Hawaiian Islandsinfluences of area, environment and paleogeography: Journal of Biogeography, v. 31, no. 3, p. 487-500.

Price, J.P., Gon, S.M., III, Jacobi, J.D., and Matsuwaki, D., 2007, Mapping plant species in ranges in the Hawaiian Islands-Developing a methodology and associated GIS layers: University of Hawai' $i$ at Hilo, Hawai' $i$ Cooperative Studies Unit Technical Report HCSU-008, 58 p., available at http://hdl.handle.net/10790/2687.

Price, J.P., Jacobi, J.D., Gon, S.M., III, Matsuwaki, D., Mehrhoff, L., Wagner, W., Lucas, M., and Rowe, B., 2012, Mapping plant species ranges in the Hawaiian IslandsDeveloping a methodology and associated GIS layers: U.S. Geological Survey Open-File Report 2012-1192, 34 p., 1 appendix (species table), 1,158 maps, available at http:// pubs.usgs.gov/of/2012/1192/.

Rangwala, I., Sinsky, E., and Miller, J.R., 2013, Amplified warming projections for high altitude regions of the northern hemisphere mid-latitudes from CMIP5 models: Environmental Research Letters, v. 8, no. 2, 9 p., available at http://dx.doi.org/10.1088/1748-9326/8/2/024040

R Core Team, 2014, R-A language and environment for statistical computing: Vienna, Austria, R Foundation for Statistical Computing, https://www.r-project.org.

Ridgeway, G., 2005, Generalized boosted models-A guide to the gbm package.

Rock, J.F., 1913, The indigenous trees of the Hawaiian Islands: Honolulu, privately published.

Rollins, M.G., 2009, LANDFIRE: A nationally consistent vegetation, wildland fire, and fuel assessment: International Journal of Wildland Fire, v. 18, p. 235-249. 
Sperling, F.N., Washington, R., and Whittaker, R.J., 2004, Future climate change of the subtropical North Atlanticimplications for the cloud forests of Tenerife: Climatic Change, v. 65 , no. 1, p. 103-123.

Still, C.J., Foster, P.N., and Schneider, S.H., 1999, Simulating the effects of climate change on tropical montane cloud forests. Nature, v. 398, p. 608-610.

Tovar, C., C.A. Arnillas, Cuesta, F., and Buytaert, W., 2013, Diverging responses of tropical Andean biomes under future climate conditions: PLoS ONE, v. 8, no. 5, 12 p., available at http://dx.doi.org/10.1371/journal. pone. 0063634 .
Weiss, J.L., Castro, C.L., and Overpeck, J.T., 2009, Distinguishing pronounced droughts in the Southwestern United Statesseasonality and effects of warmer temperatures: Journal of Climate, v. 22, no. 22, p. 5918-5932 available at http://dx.doi. org/10.1175/2009JCLI2905.1.

Zhang, C., Wang, Y., Lauer, A., and Hamilton, K., 2012, Configuration and evaluation of the WRF model for the study of Hawaiian regional climate: Monthly Weather Review, v. 140, no. 10, p. 3259-3277, available at http://dx.doi.org/10.1175/ MWR-D-11-00260.1.

Ziegler, A.C., 2002, Hawaiian Natural History, Ecology, and Evolution: Honolulu, University of Hawaii Press, 477 p. 


\title{
Chapter 4. Influence of Invasive Species on Carbon Storage in Hawai'i's Ecosystems
}

\author{
By R. Flint Hughes, ${ }^{1}$ Gregory P. Asner, ${ }^{2}$ Creighton M. Litton, ${ }^{3}$ Paul C. Selmants, ${ }^{4}$ Todd J. Hawbaker, ${ }^{4}$ James D. Jacobi, ${ }^{4}$ \\ Christian P. Giardina, ${ }^{1}$ and Benjamin M. Sleeter ${ }^{4}$
}

\subsection{Highlights}

- Invasive species are widely distributed among most of Hawai'i's forests, woodlands, shrublands, and grasslands.

- Primary groups of invasive nonnative species include nitrogen-fixing trees and shrubs, non-nitrogen-fixing trees and shrubs, and grasses. Each species within these groups may have a positive, negative, or neutral effect on carbon stocks, depending on the structural and functional characteristics of the invader as well as those of the native communities undergoing invasion. Common invasion scenarios and their ramifications for carbon storage and cycling are presented.

- Although there is worldwide interest to protect and even increase carbon storage in ecosystems to mitigate climate change (Intergovernmental Panel on Climate Change, 2006), and invasion of nonnative plants into Hawai'i's ecosystems may, in some cases, increase carbon stocks across landscapes of Hawai' $i$, invasive species are commonly the primary cause of profound, and in many cases irreparable, damage to Hawai 'i's native ecosystems, degrading their compositional, structural, and functional integrity. In addition, it is not clear whether any carbon sequestration benefit of invasive species can be sustained on a long-term basis.

\subsection{Introduction}

Nonnative invasive species have altered virtually all Hawaiian terrestrial ecosystems in a variety of ways, including substantial changes to the storage, production, and cycling of

\footnotetext{
${ }^{1}$ U.S. Department of Agriculture Forest Service.

${ }^{2}$ Carnegie Institution for Science.

${ }^{3}$ University of Hawai'i at Mānoa.

${ }^{4}$ U.S. Geological Survey.
}

carbon (Ehrenfeld, 2003). Globally, nonnative species have changed the composition, structure, and function of countless native ecosystems (Elton, 1958; Vitousek and others, 1996), and the extent and influence of nonnative species invasions are considered substantial components of global environmental change (Vitousek and others, 1997). In turn, other aspects of environmental change (for example, land-use change, nitrogen deposition, and increased atmospheric- $\mathrm{CO}_{2}$ concentrations) have likely amplified the spread and influence of invasive species (Dukes and Mooney, 1999). Nonnative species may alter carbon storage and dynamics by invading open niches in plant communities or by displacing native species by virtue of greater competitive ability and (or) reproductive output. However, nonnative species that generate the largest changes in carbon storage and cycling in ecosystems are those with the capacity to alter ecosystem processes, in effect resetting the rules under which all other species in the system operate (Vitousek, Walker, and others, 1987). Such processes include hydrology, geomorphology, nutrient cycling, natural disturbance regimes, primary production, and decomposition (Vitousek and others, 1997). These latter two processes represent the most direct determinants of carbon storage and cycling in ecosystems.

Isolated oceanic islands are generally more susceptible to, and more heavily impacted by, nonnative species invasions than are continental systems. Island species collectively tend to exhibit proportionally higher levels of endemism (species found only on said islands), lower levels of diversity, commonly disharmonic plant and animal communities (lacking important functional or structural components, such as ants or nitrogen-fixing plants), and lower tolerance to disturbance (Vitousek, Loope, and Stone, 1987; Vitousek, 1990). The native biota of the Hawaiian Islands, Earth's most isolated archipelago, strongly exhibits these characteristics. Over 90 percent of Hawai' $i$ 's native flora is endemic, and many plant growth forms and (or) functional types that are abundant in continental systems are underrepresented or entirely absent in Hawai'i (for example, palms, pyrophytic grasses, terrestrial mammals). These attributes, coupled with high rates of nonnative-species introductions following European contact 220 years ago, have resulted in an island flora comprising about 1,200 native plant species and a 
roughly equal number of naturalized introduced nonnative species, approximately 10 percent of which are considered invasive (Vitousek, Loope, and Stone, 1987; Wagner and others, 1999).

Collectively, the Hawaiian Islands exhibit an impressive array of climatic and edaphic variation, where substrates range in age from days to millions of years, and where Hawai' $i$ Island alone harbors 25 of the world's 35 Holdridge life zones (Holdridge, 1947; Asner and others, 2005). Unfortunately, nearly all of these varied ecological zones contain nonnative invasive species capable of displacing native counterparts or altering ecological processes. Although many nonnative species were introduced inadvertently during the past two centuries, many were purposefully introduced. Of the approximately 100 nonnative plant species considered invasive and detrimental to Hawai'i's native ecosystems, more than half of them were purposefully introduced by territorial and state foresters and planted extensively across the archipelago (Woodcock, 2003). The spread of both subsets of nonnative invasive species has been exacerbated by land conversion, altered disturbance regimes (for example, agriculture, logging, grazing, fire, and residential and urban development), and domestic and feral ungulate activity (cattle, sheep, goats, and pigs). These forces have resulted in profoundly altered landscapes where nonnative species commonly dominate (Cuddihy and Stone, 1990). In many instances, such as with ungulate grazing and fire, disturbance amplifies and entrenches dominance and relative influence of the respective nonnative invasive species (Hughes and others, 1991; D’Antonio and Vitousek, 1992; Hughes and Vitousek, 1993; Brooks and others, 2004; Hawbaker and others, this volume, chap. 5).

As a result of the historical and ecological interactions discussed above, each main Hawaiian Island today exists as a matrix of native and nonnative-dominated landscapes (table 4.1 adapted from Jacobi and others, this volume, chap. 2). Nonnative invasive species are present on every main Hawaiian Island, but their areal extent and prevalence varies from island to island. Viewed as a proportion of total vegetated area of each Island occupied by nonnative species, Kaho'olawe exhibits the highest proportion (99 percent) and Hawai'i Island exhibits the lowest (42 percent). O‘ahu, Lāna'i, and Moloka'i exhibit roughly similar proportions (81-86 percent), as do the islands of Maui and Kaua' $i$ (63 and 70 percent, respectively). Clearly, the extent of nonnative occupancy is high by any measure, and relative proportions of nonnative vegetation highlight the widespread importance of nonnative invasive vegetation across much of the Hawaiian archipelago.

How do alien-dominated vegetation assemblages affect terrestrial carbon storage and dynamics relative to the remaining native-dominated areas or former native-dominated areas that they have replaced? The answer depends upon the ecosystem or ecological zone in question, the particular nonnative species or collection of nonnative species that have invaded, as well as the timeframe. For example, in moist-to-wet windward zones of the Hawaiian Islands, the "carbon effect" (in other words, whether the system experiences a net loss or gain of carbon) associated with shifts from native-dominated forest to nonnative forest or shrubland depends on the maturity and development of the native forest being displaced or altered and, perhaps more importantly, on the stature and growth characteristics of the nonnative species that ultimately dominate a given ecosystem following invasion.

The objectives of this chapter are to synthesize existing information and improve our understanding of the patterns and dynamics of carbon storage, particularly aboveground carbon storage, across a variety of common invasion scenarios found in the Hawaiian Islands (table 4.2). Here we draw upon published results to explore the dynamics of invasion and characterize their associated patterns of carbon storage. Specifically, we focus on three dominant nonnative functional guilds: nitrogen-fixing trees

Table 4.1. Current extent of native-dominated and nonnative-invaded vegetation types on each of the main Hawaiian Islands.

\begin{tabular}{lccccc}
\hline \multirow{2}{*}{ Island } & $\begin{array}{c}\text { Total vegetated area } \\
\left.\mathbf{( k m}^{2}\right)\end{array}$ & \multicolumn{2}{c}{ Native dominated } & \multicolumn{2}{c}{ Nonnative invaded } \\
\cline { 3 - 6 } & 6,937 & 4,021 & 58 & 2,915 & 42 \\
\hline Hawai'i & 1,311 & 489 & 37 & 822 & 63 \\
\hline Maui & 1,083 & 323 & 30 & 760 & 70 \\
\hline Kaua'i & 987 & 162 & 16 & 825 & 84 \\
\hline O‘ahu & 606 & 115 & 19 & 491 & 81 \\
\hline Moloka‘i & 344 & 49 & 14 & 295 & 86 \\
\hline Lāna'i & 90 & 1 & 1 & 90 & 99 \\
\hline Kaho'olawe & & & & & Percent of total \\
\hline
\end{tabular}

\footnotetext{
${ }^{1}$ Denotes plant communities either dominated by nonnative species or where nonnative species are a significant component of the community.
} 
Table 4.2. General effects of invasion by three main nonnative functional guilds on carbon pools of three differing native-dominated community types.

[Arrows indicate changes (increase, $\uparrow$; decrease, $\downarrow$; or no change, $\leftrightarrow$ ) on overall carbon pools following invasion. $\mathrm{N}$, nitrogen]

\begin{tabular}{lccc}
\hline \multirow{2}{*}{ Native-dominated community } & \multicolumn{3}{c}{ Non-native functional guild } \\
\cline { 2 - 4 } & N-fixing woody & Non N-fixing woody & Grasses \\
\hline N-fixing forest & $\leftrightarrow$ & $\downarrow$ & $\downarrow$ \\
Non N-fixing forest & $\uparrow$ & $\leftrightarrow$ or $\uparrow$ & $\downarrow$ \\
Grassland & $\uparrow$ & $\uparrow$ & $\leftrightarrow$ \\
\hline
\end{tabular}

and shrubs, non-nitrogen-fixing trees and shrubs, and grasses. We also note that the effect of invasion on carbon storage is as much influenced by the carbon stocks of the pre-invasion native community as the particular characteristics of the respective invasive nonnative species and (or) guilds (table 4.2).

\subsection{Input Data and Methods}

Our area of interest encompasses the Hawaiian Islands, and includes the wide variety of invasive species and invaded communities present throughout the archipelago. We illustrate prominent examples of nonnative invasive plants and their impact on carbon cycling and storage-usually in relation to those of adjacent native-dominated plant communities - using data compiled from published literature.

\subsection{Results and Discussion}

\subsubsection{Nitrogen-Fixing Trees and Shrubs}

Invasive species that have the capacity to fix nitrogen through symbiotic associations with Rhizobia, in the case of legumes, or Frankia, in the case of actinorhizal plants, are capable of altering the function and composition of the native ecosystems. This has been documented in numerous settings around the world (Ehrenfeld, 2003), perhaps most notably in Hawai' $i$ (Vitousek, Walker, and others, 1987) where native nitrogen-fixing species - particularly those exhibiting early-successional pioneer characteristics - are relatively uncommon, and where many native ecosystems are nitrogen-limited (Vitousek and Farrington, 1997). Many of Hawai'i's more problematic invasive alien species are those that fix nitrogen. Although invasive nitrogen-fixing plants generally increase net primary production of the ecosystems they invade, the sign and degree of carbon-storage change depends on the individual characteristics of the invasive species and the successional characteristics of the invaded system.

\subsubsection{Falcataria moluccana and Casuarina equisetifolia}

In extant native-dominated wet forests along Hawai' $i$ Island's windward coastal lowlands ( $<900 \mathrm{~m}$ above sea level), two alien nitrogen-fixing tree species-Falcataria moluccana (also known as albizia) and Casuarina equisetifolia - can alter both nutrient cycling and carbon storage at the stand to ecosystem levels (Hughes and Denslow, 2005; Mascaro and others, 2012; Hughes and others, 2014). Prior to invasion of these tree species, primary succession by native vegetation in these areas typically manifests as colonization of young, barren pāhoehoe and 'a'ā lava substrates by a single cohort of Metrosideros polymorpha, which gradually develops as monotypic forest stand during the first 100-200 years (MuellerDombois and Fosberg, 1998), and which ultimately develops into more diverse and structurally complex native forests as species establish during subsequent centuries of succession (200-700 years) (Zimmerman and others, 2008). Earlysuccessional native forests on young lava flows ( $<200$ years) exhibit aboveground carbon densities (ACDs) averaging less than 60 megagrams of carbon per hectare $(\mathrm{MgC} / \mathrm{ha})$. On older lava flows (400-750 years), native forests, having had the time to gradually accumulate substantial amounts of biomass, exhibit ACD values of $130 \mathrm{MgC} / \mathrm{ha}$ (fig. 4.1).

Although native-dominated vegetation can still be found in lowland wet habitats of east Hawai'i Island, substantial portions are now occupied by nonnative tree and shrub species purposefully introduced as part of massive nonnative-tree-planting efforts that took place across Hawai' $i$ throughout the 1900s.

Over 10,000 nonnative species were introduced into Hawai ${ }^{\circ} i$ and more than 13 million individuals were planted in what has been characterized as the largest environmental project ever conducted in Hawai' $i$ (Woodcock, 2003). Of the approximately 100 species now considered invasive in Hawai' $i$, half were introduced during that period. In Forest Reserves of the Puna District of Hawai' $i$ Island, in an area totaling about 2,000 ha, nearly 35,000 individuals of 114 different species, 74 distinct genera, and 38 plant families were planted between 1906 and 1960 (Skolmen, 1963; Nelson, 1965). Among the most commonly planted species were $C$. equisetifolia and F. moluccana. This latter species, 
Figure 4.1. Plot of aboveground carbon density in native-dominated and nonnative-dominated forest stands along a gradient of $\mathrm{MgC} / \mathrm{ha}$, megagrams of carbon per hectare increasing lava age in Hawaiti.

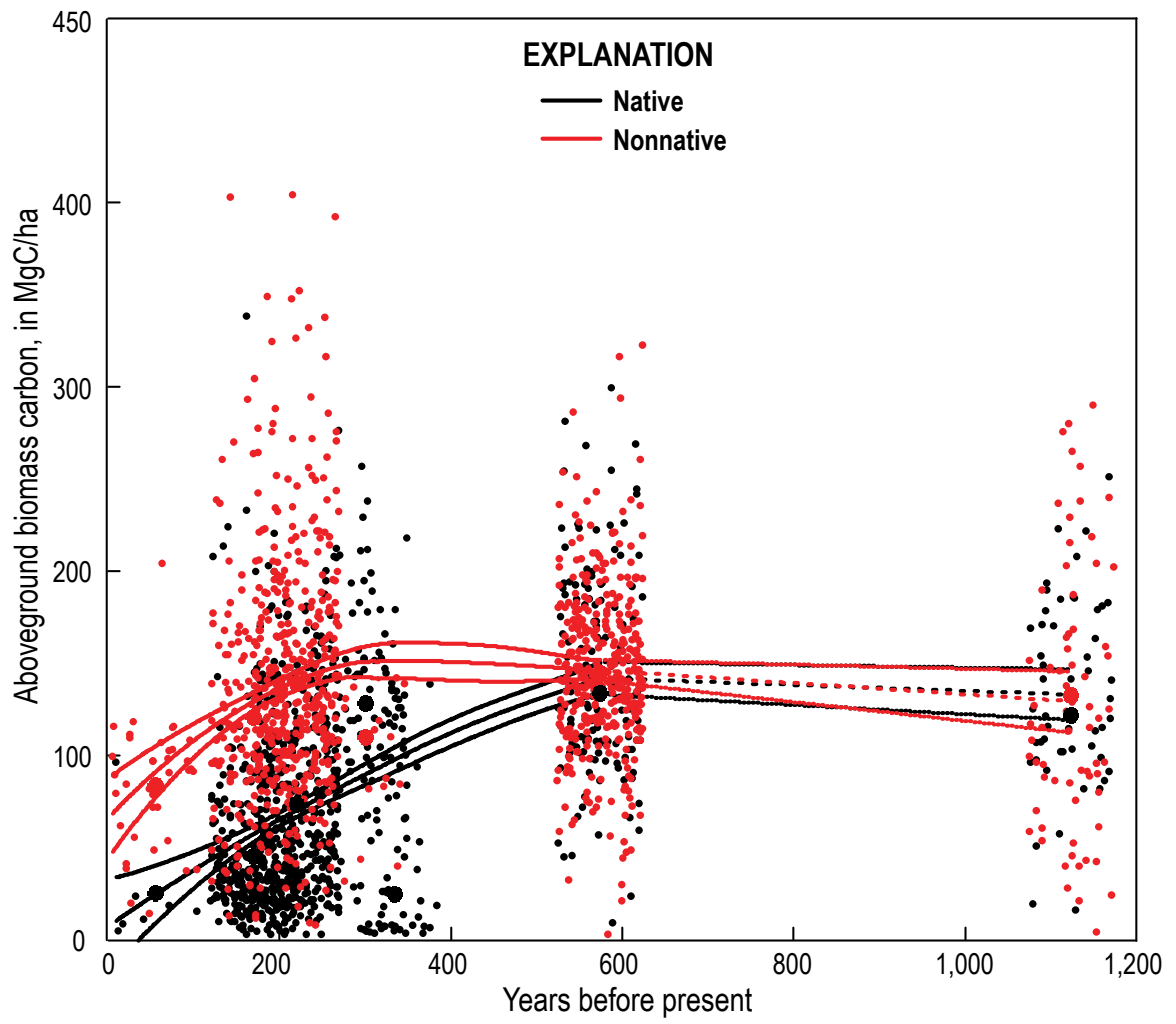

native to the Molucca Islands, New Guinea, New Britain, and the Solomon Islands and first introduced to Hawai' $\mathrm{i}$ in 1917, is a legume that fixes nitrogen through its symbiosis with Rhizobia. In contrast, $C$. equisetifolia, a tree native to Australia and introduced to Hawai' $i$ in the 1890s, is an actinorhizal tree species that fixes nitrogen through its symbiosis with Frankia.

Although patterns of aboveground carbon accumulation among native forest stands were strongly controlled by lava substrate age and developed within century-scale timeframes, patterns of accumulation among $F$. moluccana and C. equisetifolia stands were decoupled from substrate age and developed within decadal-scale timeframes (fig. 4.1). Indeed, all nonnative forest stands inventoried by Hughes and others (2014) were established during the $1900 \mathrm{~s}$ - some as late as 1955 - and their ACD values were the result of no more than 90 years of succession. This attests to their capacity for comparatively rapid rates of ACD accumulation, particularly where such stands were dominated by tree species capable of symbiotic nitrogen fixation. On older lava substrates however, ACDs of native and nonnative stands were shown to be quite similar. Thus, comparisons between ACDs of native and nonnative nitrogen-fixing tree-dominated forests was highly dependent on lava substrate age and, hence, forest successional state. By virtue of their nitrogen-fixing capacities, the fast growing nitrogen-fixing trees F. moluccana and $C$. equisetifolia rapidly surpass ACDs of the slower growing dominant native tree M. polymorpha on young, nitrogen-limited lava flows. In contrast, although F. moluccana and C. equisetifolia attain ACD levels of about $130 \mathrm{MgC} / \mathrm{ha}$ in a matter of only a few decades on older lava substrate, those levels remain on a par with native-dominated M. polymorpha forests that have experienced centuries of succession and carbon accumulation.

In addition to increasing $\mathrm{ACD}$ relative to that of native forests on young lava flows, Mascaro and others (2012) found that on lava flows aged 300 years before present and younger, both F. moluccana- and C. equisetifolia-dominated forest stands exhibited rates of litterfall, aboveground growth increment, and aboveground net primary production that were at least triple the same rates for native forest stands dominated by M. polymorpha on similarly aged lava flows. These authors also found that belowground carbon mass values of $F$. moluccana- and $C$. equisetifolia-dominated forests ( $\sim 48 \mathrm{MgC} / \mathrm{ha}$ ) were more than double those of $M$. polymorpha-dominated forest on young lava flows $(20 \mathrm{MgC} / \mathrm{ha})$. Again, the mechanism for such high rates of carbon cycling, accumulation, and storage is clear: newly formed lava substrates notably lack plant-available nitrogen (Vitousek and others, 1993), and inputs from sources other than higher plants (for example, precipitation and dry deposition, free-living cyanobacteria, and heterotrophic bacteria) are relatively low (Hughes and Denslow, 2005). The capacity of F. moluccana and C. equisetifolia to symbiotically fix nitrogen frees them from constraints posed by nitrogen limitation and allows for large increases in primary production, and increased nutrient acquisition (particularly phosphorus) (Binkley and others, 2004; Mascaro and others, 2012). In contrast, M. polymorpha, virtually the sole woody plant component of native-dominated primary succession on these lava flows, lacks the capacity to symbiotically fix nitrogen, and its productivity is highly constrained by nitrogen limitation (Hughes and Denslow, 2005; Mascaro and others, 2012). 


\subsubsection{Morella faya}

In sub-montane and montane areas of Hawai $i \mathrm{i}$ Volcanoes National Park (HVNP) on the Island of Hawai' $i$, Vitousek and Walker (1989) showed that invasion by Morella faya (formerly Myrica faya) dramatically alters the functions of the formerly native-dominated community by quadrupling the amount of biologically available nitrogen entering these typically nitrogenlimited systems. Originally introduced to Hawai $i \mathrm{i}$ by Portuguese immigrants in the 19th century, M. faya is native to the Azores, Canary, and Madeira Islands; it is an actinorhizal nitrogen fixer that, like F. moluccana and Casuarina species, was planted widely throughout the main Hawaiian Islands during the early 20th century until its invasive potential was realized (Fosberg, 1937; Vitousek and Walker, 1989). First recorded in HVNP in 1961, M. faya occupied more than 12,000 ha of the Park by 1985 (Whiteaker and Gardner, 1985), and its distribution has increased dramatically during the last 30 years, particularly in seasonally dry portions of HVNP (D'Antonio and others, 2011). Numerous studies have demonstrated reinforcing effects of $M$. faya invasion on biogeochemical processes; these include increased trace gas emissions, litterfall, and soil organic carbon (Vitousek and Walker, 1989; Aplet, 1990; Hall and Asner, 2007).

Regarding the influence of $M$. faya invasion on aboveground carbon stocks, Asner and others (2010) compared nativedominated and $M$. faya-invaded communities along a shrublandwoodland-forest gradient (fig. 4.2). Although aboveground biomass (AGB) more than quadrupled from shrubland to forest

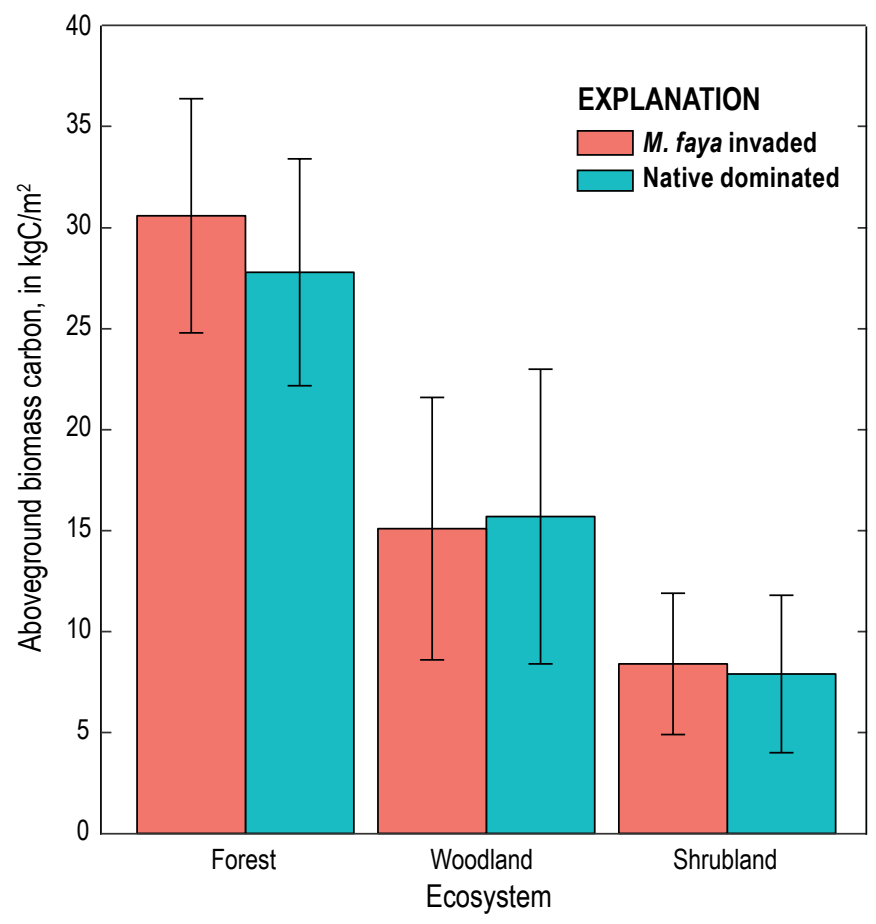

Figure 4.2. Plot of aboveground biomass carbon of nativedominated and Morella faya-invaded ecosystems in Hawai'i Volcanoes National Park (data from Asner and others, 2010). $\mathrm{kgC} / \mathrm{m}^{2}$, kilograms of carbon per square meter. communities, M. faya AGB did not differ from that of nativedominated AGB in any of the three ecosystem types. As such, despite its capacity to substantially alter other ecosystem functions and characteristics, $M$. faya invasion failed to alter aboveground carbon stocks in any of the ecosystems it invaded in HVNP.

\subsubsection{Prosopis pallida and Leucaena leucocephala}

In arid ecosystems of Hawai' $i$, such as those on the leeward sides of the main Hawaiian Islands, the impact of invasive nitrogen fixers on carbon cycling and stocks is primarily controlled by water availability. Two widespread nitrogen-fixing trees exemplary of this are Prosopis pallida and Leucaena leucocephala; both are members of the Fabaceae family and as such fix nitrogen by symbiosis with Rhizobia. Both trees were introduced to Hawai' $i$ in the early 1800 s from their native range in the neotropics and naturalized rapidly across many of the arid zones of the main Hawaiian Islands (Wagner and others, 1999; Gallaher and Merlin, 2010); today they occupy a combined area of 59,000 ha, or 3.6 percent of the total land area of the Archipelago (Gon and others, 2006). Native species have been long extirpated from the vast majority of these areas, but native dry forests were likely composed of species such as Erythrina sandwicensis, Reynoldsia sandwicensis, and Abutilon incanum (Wagner and others, 1999).

In investigations into the effects of groundwater availability on plant-soil nitrogen cycling in areas invaded by P. pallida on the dry leeward coast of Hawai'i Island, Dudley and others (2014) compared nutrient acquisition and cycling as well as productivity of $P$. pallida trees growing in lowland areas where they could access shallow groundwater with $P$. pallida trees growing in upland areas where they had to rely solely on low volume, intermittent rainfall events. The authors found that $P$. pallida in upland environs experienced water stress, exhibited higher water-use efficiency, and exhibited lower predawn photosynthetic performance than did trees in lowland areas. Further, biologically available soil nitrogen pools and litter production were 10 and 17 times greater, respectively, in lowland P. pallida stands relative to upland stands. Differences in these functional attributes translated to large differences in ACD; lowland P. pallida stand-level carbon mass (20 MgC/ha) was more than six times greater than that of upland P. pallida stands (fig. 4.3). In the case of $P$. pallida invasion and growth across substantial portions of the main Hawaiian Islands, the degree to which these forests and woodlands store and cycle carbon is highly dependent on water availability.

In dry, leeward, lowland environments of the main Hawaiian Islands invaded and now occupied by $P$. pallida or L. leucocephala stands, associated herbaceous or grass biomass may contribute substantially to ecosystem carbon stocks and cycling. Ellsworth and others (2014) determined aboveground carbon mass in L. leucocephala-dominated woodlands; they found that although carbon mass in live biomass of the alien tree was generally greater than that in live grass biomass, the collective carbon mass of living and dead grass biomass was at least comparable, if not greater than, the 


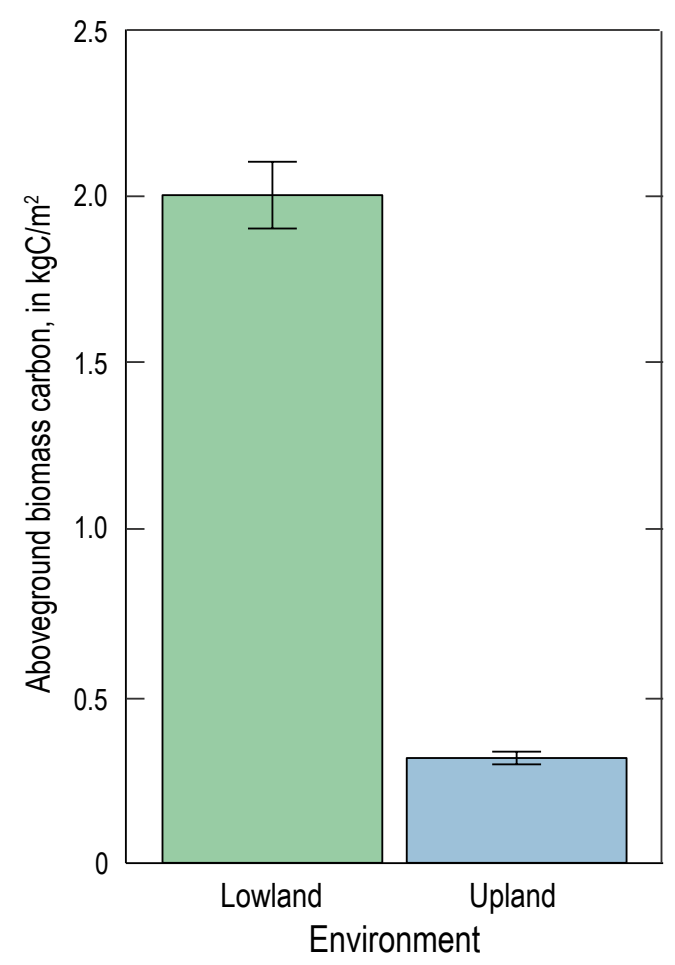

Figure 4.3. Plot of aboveground biomass carbon of Prosopis pallida forest stands in upland and lowland environments along the dry leeward coast of Hawai'i Island (R. Flint Hughes, U.S. Department of Agriculture, Forest Service, unpublished data). Lowland stands have ample access to groundwater; upland stands do not have such access. $\mathrm{kgC} / \mathrm{m}^{2}$, kilograms of carbon per square meter.

combined living and dead mass of L. leucocephala (fig. 4.4). This is a common characteristic of many dry leeward systems invaded by $P$. pallida and L. leucocephala, and it likely results from increases in soil-nitrogen availability beneath these nitrogen-fixing tree species that facilitate the establishment and persistence of other plant species which, more commonly than not, tend to be introduced nonnatives (Dudley and others, 2014). In some cases, however, P. pallida and L. leucocephala stands lack herbaceous understories of any note, perhaps owing to heightened competition for scarce water resources.

Facilitation of other introduced alien plant species by virtue of increased nitrogen availability is a salient feature of invasive alien nitrogen-fixing tree species of Hawai' $i$, and this aspect commonly has a compounding effect on carbon stocks and cycling. Hughes and Denslow (2005) found that invasion of F. moluccana in lowland wet forests growing on young lava flows dramatically increased stem densities, basal area, and consequently ACD of the nonnative tree, Psidium cattleianum, relative to native-dominated forests on lava flows of comparable age and type. Asner and others (2008) documented similar changes in forest structure following invasion by alien nitrogen-fixing trees, and Vitousek and Walker (1989) noted establishment and rapid growth of $P$. cattleianum seedlings under canopies of $M$. faya on young

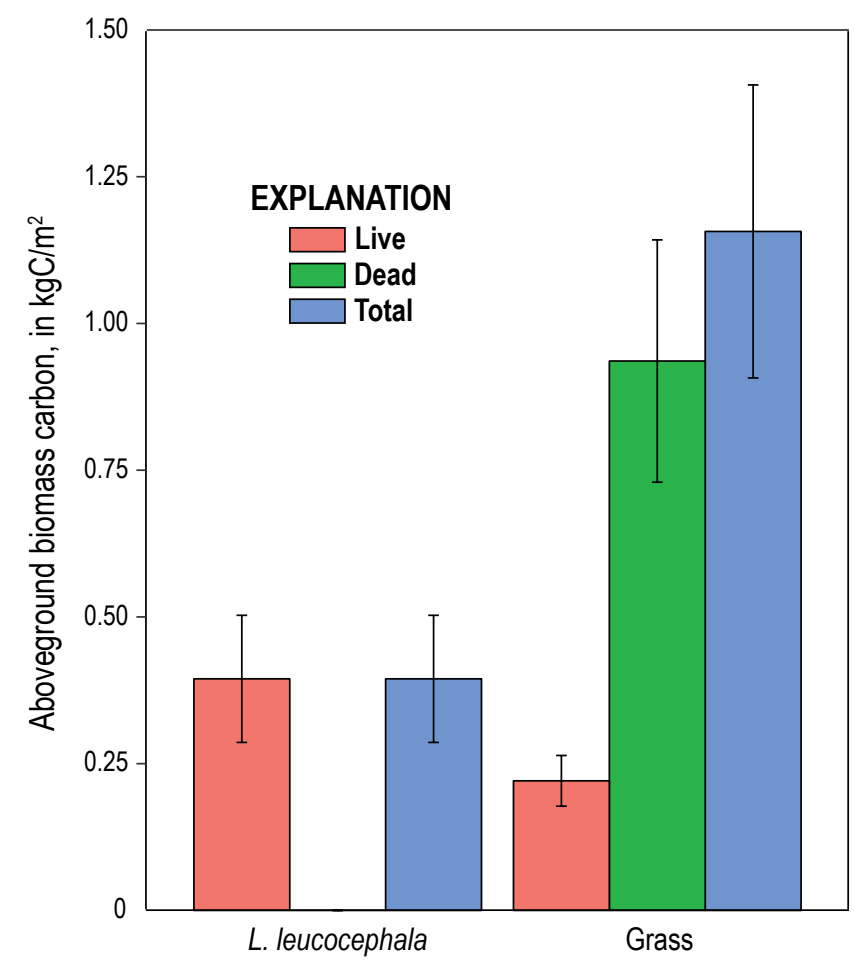

Figure 4.4. Plot of aboveground biomass carbon of Leucaena leucocephala stands and associated grass biomass in dry leeward lowland environments of O'ahu (modified from Ellsworth and others, 2014). $\mathrm{kgC} / \mathrm{m}^{2}$, kilograms of carbon per square meter.

lava substrates that otherwise would be inhospitable to $P$. cattleianum invasion.

\subsubsection{Non-Nitrogen-Fixing Trees and Shrubs}

Many nonnative species that have successfully invaded a wide variety of Hawai'i's ecosystem do not have the capacity to fix nitrogen. Their effect on the balance of carbon stocks depends on their size and stature relative to native species and the degree to which they displace, rather than simply augment, ecosystem carbon stocks.

\subsubsection{Fraxinus uhdei}

Native to central and southern Mexico, Fraxinus uhdei trees were introduced to Hawai' $i$ in the late 1800 s and planted extensively across the archipelago; more than 700,000 individuals were planted on most of the main Hawaiian Islands (Wagner and others, 1999). This nonnative tree can attain heights up to $24 \mathrm{~m}$ and grow in relatively dense stands. F. uhdei can be fast growing in wet sub-montane or montane forests of Hawai' $i$ and is responsive to increases in soil-nitrogen availability (Ares and Fownes, 2001), making it well suited to invading disturbed 
sites during secondary succession. Rothstein and others (2004) found that $F$. uhdei increased nutrient cycling at the stand scale, though limited light availability in the understory apparently constrains subcanopy biomass. As such, establishment of this nonnative tree results in displacement of native species. However, because this tree is large, mature stands contain high amounts of carbon. In montane forests of the Laupahoehoe Unit of the Hawai'i Experimental Tropical Forest (HETF) on the windward side of Hawai'i Island, Asner and others (2009) found that, although native M. polymorpha and Acacia koa forests averaged $65 \mathrm{MgC} /$ ha, $F$. uhdei-dominated stands averaged more than four times that amount ( $254 \mathrm{MgC} / \mathrm{ha})$. Again these high values were not a function of $F$. uhdei augmenting native forests present in the locality. Rather, they reflect the displacement of native forests by alien tree species with a much higher capacity to acquire and store carbon.

\subsubsection{Psidium cattleianum}

In contrast to large trees such as $F$. uhdei, smaller stature non-nitrogen-fixing trees such as $P$. cattleianum typically decrease aboveground carbon storage in areas where it invades. Native to Brazil, $P$. cattleianum was introduced to Hawai' $i$ in the early 1800 s and has since become widespread across all the main Hawaiian Islands except $\mathrm{Ni}^{\prime}$ 'ihau and Kaho'olawe (Wagner and others, 1999). It is considered one of the most serious weeds of Hawai' $i$ (Smith, 1985). Its capacity to reproduce vegetatively (in other words, by rootsprouts or suckers), combined with its shade tolerance, enables it to invade otherwise undisturbed native forests, and it is currently the most widespread alien woody species in Hawai'i's mesic-, moist-, and wet-forest zones. Once established in a particular locality, P. cattleianum commonly forms dense, impenetrable thickets in understories of dominant canopy trees, whether native (for example, M. polymorpha) or nonnative (for example, F. moluccana or C. equisetifolia) (Hughes and Denslow, 2005; Asner and others, 2008). While not explicitly altering ecosystem function, $P$. cattleianum is a strong competitor for limiting resources such as light, water, and nutrients, and it represents a daunting obstacle to native-species recruitment; forest stands characterized by a native overstory canopy and a dense sub-canopy of $P$. cattleianum will most likely retrogress to monotypic thickets of this aggressive invader once the mature native trees senesce (Zimmerman and others, 2008; Hughes and others, 2014). Regarding carbon storage, Asner and others (2008) reported a general diminution in aboveground carbon across areas of $P$. cattleianum invasion; forest stands co-dominated by $P$. cattleianum and Ficus rubiginosa, another nonnative tree species, exhibited significantly lower aboveground carbon mass than their native-dominated counterparts on 5,000-, 20,000-, and 65,000-year-old lava substrates of the Laupahoehoe Unit of the HETF (fig. 4.5).

As a relatively small tree (typically 2-6 m tall, Wagner and others, 1999), P. cattleianum generally would be expected to harbor less carbon than the larger stature native forests they typically replace. However, in cases where stands of this species have matured to their fullest extent, it is possible for them to exhibit carbon mass roughly equivalent to that of native forests, although belowground carbon mass may be substantially greater in native-dominated stands $(108 \mathrm{MgC} / \mathrm{ha})$ relative to P. cattleianum-invaded stands $(78 \mathrm{MgC} / \mathrm{ha})$ (Mascaro and others, 2012). Regardless of whether $P$. cattleianum increases or decreases carbon stocks and cycling of the ecosystems it invades, its detrimental impacts on the diversity of Hawai'i's native biodiversity can neither be denied nor overstated.

\subsubsection{Grevillea robusta}

A member of the Proteaceae family and introduced from Australia in the late 1800s, Grevillea robusta is a common nonnative tree across dry leeward portions of the main Hawaiian Islands; more than 2.2 million individuals of this tree were planted across the archipelago by territorial foresters in the four decades between 1919 and 1959 (Wagner and others, 1999). Having spread to other areas from these initial plantings, G. robusta, along with P. pallida, constitutes most alien-dominated forests on drier, leeward parts of the Hawaiian Islands. G. robusta is a large tree, attaining heights of 10-25 m (Wagner and others, 1999); its inherent capacity to grow well even in dry, infertile soils makes it well suited to Hawai'i's leeward environments across which it has invaded (Lott and others, 2003; Shane and Lambers, 2005). Regarding

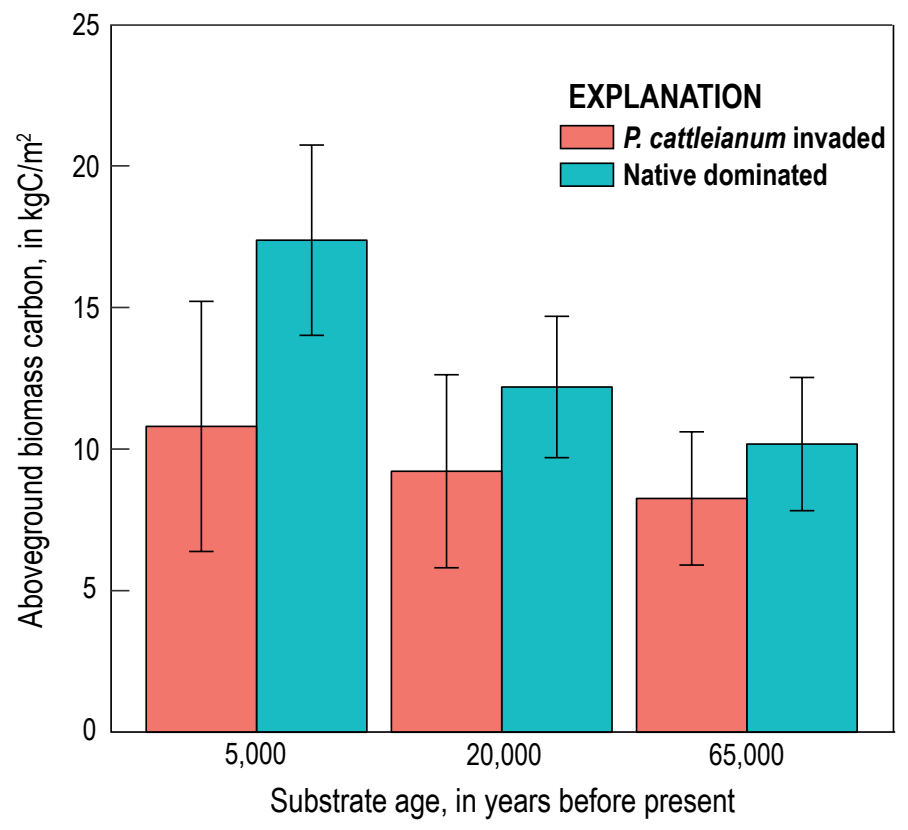

Figure 4.5. Plot of aboveground biomass carbon (mean +1 standard deviation) of native and Psidium cattleianum-invaded forest stands found on on lava substrates of three distinct age in the Laupahoehoe Unit of the Hawai' $i$ Experimental Tropical Forest on the leeward side of Hawai' $i$ Island (data from Asner and others, 2008). $\mathrm{kgC} / \mathrm{m}^{2}$, kilograms of carbon per square meter. 
Baseline and Projected Future Carbon Storage and Carbon Fluxes in Ecosystems of Hawai i

the degree to which G. robusta stores carbon (R. Flint Hughes, U.S. Department of Agriculture, Forest Service, unpublished data), found that mature stands of this species supported an average of $86 \mathrm{MgC} / \mathrm{ha}$; this value was substantially higher than that of surrounding alien grasslands $(<5 \mathrm{MgC} / \mathrm{ha})$, but comparable to that of adjacent native forests co-dominated by M. polymorpha and A. koa (100 MgC/ha). Again, whereas stocks of carbon may be quite similar between nativedominated forests and alien invaded forests of these leeward portions, the most important difference between these forest types lies in the utter lack of native diversity in the latter relative to the former forests.

\subsubsection{The Melastomes: Clidemia hirta, Melastoma septemnervium, and Miconia calvescens}

Collectively, shrubby members of the Melastomataceae introduced to Hawai' $i$ within the last 100 years, including Clidemia hirta (soap bush), Melastoma septemnervium, and Miconia calvescens (velvet tree), pose some of the most serious threats to both the native biodiversity of Hawai'i's forests and their capacity to store aboveground and belowground carbon. Native to lowlands of Central and South America and Caribbean Islands, $C$. hirta is a short stature shrub (0.5-3 m tall) first noted in Hawai' $i$ in 1941; it has spread rapidly and extensively throughout mesic-to-wet forests at low to mid elevations and has been declared a noxious weed by the Hawai'i Department of Agriculture (Wagner and others, 1999; Dewalt and others, 2004). Smith (1992) reported that $C$. hirta had spread across more than 100,000 ha on the island of $\mathrm{O}^{\prime} \mathrm{ahu}$ alone. Somewhat taller than C. hirta, M. septemnervium (1.5-5 m tall) is native to Asia, Southeast Asia, and the Philippines; it was present in Hawai' $i$ by 1928 and now occupies extensive areas on windward slopes, from sea level to $900 \mathrm{~m}$ (Wagner and others, 1999). The tallest of the three melastomes considered here, $M$. calvescens is native to South and Central America and was first introduced to Hawai' $i$ in 1961. This species is considered among the worst invasive plant species in Pacific-island wet forests, and it has been designated by the IUCN Invasive Species Specialist Group as one of the 100 worst invasive species in the world (Lowe and others, 2000; Meyer, 1996). Because of the acknowledged ecological damage wrought by $M$. calvescens in Tahiti, limiting its expansion across Hawai'i's wet forests has been a management priority during the last two decades. For example, the State of Hawai' $i$ spent $\$ 1.7$ million to control M. calvescens across the islands in the year 2000 alone, and similar funding continues today. Previous studies have shown that these invasive species are better suited to capture and efficiently use available light resources than their native wetforests counterparts (Baruch and Goldstein, 1999; Baruch and others, 2000). This is likely a key factor in their successful invasion of both disturbed and undisturbed mesic-to-wet Hawaiian forests.

Regarding the capacity of these three invasive melastomes to store and cycle carbon relative to the native species they displace, C. hirta and M. septemnervium are both better characterized as shrubs than trees, and all three species are relatively low stature compared to the much taller native trees (for example, $M$. polymorpha and $A$. koa) they displace. As such, their invasion across landscapes formerly dominated by native forests has been typically accompanied by a substantial diminution in ecosystem carbon stocks. In addition, Allison and Vitousek (2004) noted that, unlike the leaf litter of native species of Hawai'i's wet forests which tends to decompose slowly, immobilizing nutrients and stabilizing soil carbon, litter of C. hirta, M. septemnervium, and $M$. calvescens decomposes quickly, releasing nutrients in the process. As such, we would expect soils supporting these invasive melastomes to accumulate and store substantially less carbon than their native-forest counterparts. Lastly, $M$. calvescens has the capacity to further inhibit soil-carbon accumulation by increasing erosion where it is established (Meyer, 1994); the large dark leaves of this species severely constrain subcanopy light availability and, consequently, understory plant cover. At the same time, these large leaves channel precipitation in such a way as to increase the energy of throughfall water drops, thereby increasing soil loss from erosion (Nanko and others, 2015).

\subsubsection{Grasses}

Across many regions of North and South America, Africa, and Australia, fire is an integral component of healthy, well-functioning native ecosystems. This is certainly not the case for the vast majority of Hawai'i's dry leeward ecosystems and wet windward ecosystems. During the 1,000 years prior to European contact, Hawaiians used fire extensively to clear native shrublands, woodlands, and forests for cultivation (Kirch, 1982). Fire was an effective tool for this purpose because, although some native species (for example, $A$. koa and Deschampsia nubigena) exhibit adaptations to fire, most native Hawaiian plant communities are best characterized as fire independent (Cuddihy and Stone, 1990); fires prior to human settlement of the Islands were likely irregular, infrequent, and short-term disturbances that exerted little evolutionary force (Smith and Tunison, 1992; Hawbaker and others, this volume, chap. 5).

Although, native-dominated grassland ecosystems were present in Hawai' $i$ in coastal, lowland and montane areas, and were likely much more widespread than present day, most of these systems have been highly degraded and are now dominated by nonnative invasive species, including a suite of nonnative grasses. Hundreds of nonnative grass species were introduced to Hawai' $i$ following the European contact in the late 1700s (Cuddihy and Stone, 1990), and today nonnative grasses currently dominate an area of $2,785 \mathrm{~km}^{2}$, or some 25 percent of the total land area in the main Hawaiian Islands (Trauernicht and others, 2015; Jacobi and others, this volume, chap. 2), where their presence is primarily the result of either land clearing followed by grass establishment as pasture for grazing or abandonment of agricultural land followed 
by invasion of pyrophytic, nonnative grasses. Dominant nonnative grass species in Hawai' $i$ today include Cenchrus setaceus (fountain grass), Cenchrus ciliaris (buffel grass), and Andropogon virginicus (broomsedge) in drier environments and Megathyrsus maximus (guinea grass), Cenchrus clandestinus (kikuyu grass), Ehrharta stipoides (rice grass), and Holcus lanatus (velvet grass) in mesic-to-wet areas. Melinis minutiflora (molasses grass) can be locally prevalant in both dry and wet areas (Hawbaker and others, this volume, chap. 5).

At higher elevations and in more mesic conditions, many native forests were purposefully replaced by grass forage species for grazing purposes 100 or more years ago (Cuddihy and Stone, 1990). In addition, abandonment of agricultural land with the demise of the sugar cane industry has left many fallow agricultural fields that are now dominated by nonnative grasses (Trauernicht and others, 2015). Some of these areas are still actively grazed or farmed, particularly on the islands of Maui and Hawai' $i$. However, many of these areas have been abandoned during the past several decades and are, in some cases, being subsequently invaded by woody species, particularly where wildfires have not occurred and fences have been erected to exclude both domestic and feral ungulates. Native-dominated forests have also regenerated in some former pasture areas where nonnative grasses were temporarily controlled and scarification techniques allowed persistent seed banks of native, nitrogen-fixing $A$. koa to germinate and establish (Scowcroft and others, 2007).

Across many portions of dry leeward zones of the main Hawaiian Islands, replacement of native-dominated woody vegetation by nonnative invasive grasses typically involves a scenario where nonnative pyrophytic grasses invade the interstices of relatively open-canopy native woodlands and shrublands. Although it is unknown if these grasses were able to invade these areas in the absence of disturbance, it is most likely that many, if not all, of these grass invasions were facilitated by disturbance in the form of timber harvesting, grazing by domestic animals, and (or) invasion by nonnative feral ungulates (in other words, nonnative grass invasions as the passengers of ecological change) (MacDougall and Turkington, 2005). Once established, however, these nonnative grasses provide continuous flammable fuels that, when subject to frequent anthropogenic ignition sources (Trauernicht and others, 2015), facilitate frequent, widespread, and high-intensity fires that are likely far outside of the range of natural variability for native Hawaiian ecosystems (Trauernicht and others, 2015). Following fire, these grass species typically re-establish quickly and outcompete woody species in the post-fire environment, thereby facilitating a nonnative grass-wildfire cycle that is exceedingly difficult to break (D'Antonio and Vitousek, 1992). Consequently, a complete replacement of native woodlands and shrublands by nonnative grasslands often occurs, particularly when repeat fires occur in the same area over short time intervals (Hughes and others, 1991; Ainsworth and Kauffman, 2013; Hawbaker and others, this volume, chap. 5). Although generalized here, such grass invasion/wildfire scenarios are dynamic and complex, both spatially and temporally.
The consequences of nonnative grass invasions and the subsequent replacement of native, woody-dominated communities by nonnative grasslands for carbon storage are typically immediate and large (Hawbaker and others, this volume, chap. 5). Aboveground carbon storage in woody-dominated communities in Hawai' $i$ ranged from 5 to $14 \mathrm{MgC} /$ ha in dry ecosystems, 33 to $91 \mathrm{MgC} /$ ha in mesic ecosystems, and 57 to $115 \mathrm{MgC} /$ ha in wet forest ecosystems (Selmants and others, this volume, chap. 6). In contrast, average aboveground standing biomass (live and detrital) across several nonnative grassland types was found to be $3.5 \mathrm{MgC} /$ ha in C. clandestinus stands, $4.8 \mathrm{MgC} /$ ha in C. setaceus stands, 6.2 $\mathrm{MgC} /$ ha in $A$. virginicus stands, $8.7 \mathrm{MgC} /$ ha in $M$. maximus stands, and $13.7 \mathrm{MgC} /$ ha in $M$. minutiflora stands (Hawbaker and others, this volume, chap. 5). In turn, under suitable edaphic and climatic conditions and in the absence of wildfire, monotypic nonnative grasses can be subsequently invaded by nonnative woody species, some of which exhibit the capacity to fix nitrogen (for example, leguminous trees and shrubs), which increases aboveground carbon storage compared to that found in monotypic nonnative grasslands (Hawbaker and others, this volume, chap. 5).

\subsection{Summary and Conclusions}

Broadly, our results, as well as results presented elsewhere in this report (Jacobi and others, this volume, chap. 2; Selmants and others, this volume, chap. 6) show that the total extent of alien-dominated forest exceeds that of native-dominated forest in lower elevation zones on medium to older substrates in both dry and wet conditions. In contrast, most wetter, higher elevation and (or) older substrates remain dominated by native forest vegetation. Critically, we found greater ACD values in native-dominated forests at low-to-medium elevations across dry-to-mesic areas of the islands, whereas alien-dominated forests had slightly higher ACD values in wetter environments. At these broad multi-island scales, substrate age played only a small role in determining the relative difference in alien- and native-dominated forest ACD levels. This suggests strong limiting effects of nutrient-poor soils on growth and biomass accumulation for all species, independent of origin. In contrast, higher biomass of native forest canopies in drier zones on older substrates may reflect evolutionary adaptation to these environments, as well as a lack of analog tree taxa among the current alien species pool on the islands.

Overall our results suggest how native biological diversity intersects with carbon storage and how alien invasive species alter those relationships. For example, higher elevation, drier forests on older substrates may be dominated by alien forest cover, but native-dominated forests in similar environments can support twice the stored carbon on a per-area basis. Thus actions to conserve and restore high-elevation native ecosystems yield a co-benefit of increased carbon storage. On the other hand, areas characterized by young substrates in drier, high-elevation areas are currently dominated by native forest cover; alien species can double ACD levels in these environments. Forest managers and conservationists can use these landscape-scale relationships as 
tradeoffs in planning efforts to increase carbon storage while managing for biological diversity.

Invasive species of one sort or another are ubiquitous across most of Hawai 'i's forests, woodlands, shrublands, and grasslands, and introductions of these species continue to this day.

We acknowledge the worldwide interest to protect and even increase carbon storage in ecosystems in order to mitigate climate change (Intergovernmental Panel on Climate Change, 2006), and we have found that in some instances invasion of nonnative plants into Hawai' $i$ 's ecosystems can increase ACD across landscapes. However, invasive species are often the primary cause of profound, and in many cases irreparable, damage to Hawai'i's native ecosystems, degrading their compositional, structural, and functional integrity in myriad ways. Considering this, it is difficult to invoke a positive benefit of invasive species in terms of ecosystem services (increased carbon sequestration, for example) for Hawai'i's ecosystems, particularly when its citizens increasingly view nonnative species (for example, the tree $F$. moluccana or pyrophytic nonnative grasses) as financial burdens at best and threats to life and property at worst (Hughes and others, 2013).

Further, the Hawaiian archipelago as a whole has been identified as a prominent biodiversity hotspot (Myers and others, 2000), and Hawai' $i$ is a prime example of how islands contain disproportionately high levels of Earth's biodiversity (Caujape-Castells and others, 2010). Although our discussion here indicates that continued invasion of native-dominated ecosystems by nonnative species may or may not increase carbon stocks at landscape scales, such transformations would further erode the important contributions of Hawai'i's native ecosystems to global biodiversity.

As such, although national and international programs that promote carbon sequestration (for example, HIREDD and California Carbon Program) provide useful mechanisms to encourage and enable landowners and land managers to reestablish and (or) protect native ecosystems of any sort, they should not be used to justify projects that lead to further establishment and persistence of invasive species. The idea that increased carbon sequestration by nonnative invasive species, where it actually occurs, could somehow justify the maintenance of invasive species across landscapes is a fallacy. Indeed, the degree to which invasive species are capable of invading native communities defines the degree that they themselves are "primary pathogens" to those ecosystems and such invasions cannot be considered compatible with the persistence of native-dominated ecosystems. The assertion Vitousek and others (1997) made two decades ago remains true today; that, "People and institutions working to understand, prevent, and control invasions [both in Hawai' $i$ and globally] are carrying out some of the most important - and potentially most effective-work on global environmental change".

\subsection{References Cited}

Ainsworth, A., and Kauffman, J.B., 2013, Effects of repeated fires on native plant community development at Hawai' $i$ Volcanoes National Park: International Journal of Wildland Fire, v. 22, p. 1044-1054, available at http://dx.doi.org/10.1071/WF12135.

Allison, S.D., and Vitousek, P.M., 2004, Rapid nutrient cycling in leaf litter from invasive plants in Hawai'i: Oecologia, v. 141, no. 4 , p. $612-619$.

Aplet, G.H., 1990, Alteration of earthworm community biomass by the alien Myrica faya in Hawai'i: Oecologia, v. 83, no. 3, p. $414-416$.

Asner, G.P., Elmore, A.J., Hughes, R.F., Warner, A.S., Vitousek, P.M., 2005, Ecosystem structure along bioclimatic gradients in Hawai' $i$ from imaging spectroscopy: Remote Sensing of Environment, v. 96, p. 497-508.

Asner, G.P., Hughes, R.F., Varga, T.A., Knapp, D.E., and Kennedy-Bowdoin, T., 2009, Environmental and biotic controls over aboveground biomass throughout a tropical rain forest: Ecosystems, v. 12, no. 2, p. 261-278, available at http://dx.doi. org/10.1007/s10021-008-9221-5.

Asner, G.P., Hughes, R.F., Vitousek, P.M., Knapp, D.E., Kennedy-Bowdoin, T., Boardman, J., Martin, R.E., Eastwood, M., and Green, R.O., 2008, Invasive plants transform the three-dimensional structure of rain forests: Proceedings of the National Academy of Sciences, v. 105, no. 11 , p. 4519-4523.

Asner, G.P., Martin, R.E., Knapp, D.E., and KennedyBowdoin, T., 2010, Effects of Morella faya tree invasion on aboveground carbon storage in Hawaii: Biological Invasions, v. 12 , no. 3 , p. 477-494, available at http://dx.doi. org/10.1007/s10530-009-9452-1.

Baruch, Z., and Goldstein, G., 1999, Leaf construction cost, nutrient concentration, and net $\mathrm{CO}_{2}$ assimilation of native and invasive species in Hawai' $i$ : Oecologia, v. 121, p. 183-192.

Baruch, Z., R.R. Pattison, G. Goldstein, 2000, Responses to light and water availability of four invasive Melastomataceae in the Hawaiian Islands: International Journal of Plant Sciences, v. 161, p. 107-118.

Binkley, D., Stape, J.L., and Ryan, M.G., 2004, Thinking about efficiency of resource use in forests: Forest Ecology and Management, v. 193, p. 5-16.

Brooks, M.L., D’Antonio, C.M., Richardson, D.M., Grace, J.B., Keeley, J.E., DiTomaso, J.M., Hobbs, R.J., Pellant, M., Pyke, D., 2004, Effects of invasive alien plants on fire regimes: Bioscience, v. 54, no. 7, p. 677-688. 
Caujape-Castells, J., Tye, A., Crawford, D.J., SantosGuerra, A., Sakai, A., Beaver, K., Lobin, W., Vincent Florens, F.B., Moura, M., Jardim, R., Gómes, I., Kueffer, C., 2010, Conservation of oceanic island florasPresent and future global challenges: Perspectives in Plant Ecology, Evolution and Systematics, v. 12, no. 2, p. 107-129, available at http://dx.doi.org/10.1016/j. ppees.2009.10.001.

Cuddihy, L.W., and Stone, C.P., 1990, Alteration of native Hawaiian vegetation - Effects of humans, their activities and introductions: Honolulu, University of Hawai'i Press, $138 \mathrm{p}$.

D'Antonio, C.M., Hughes, R.F., Tunison, J.T., 2011, Long-term impacts of invasive grasses and subsequent fire in seasonally dry Hawaiian woodlands: Ecological Applications, v. 21, no. 5, p. 1617-1628, available at http:// dx.doi.org/10.1890/10-0638.1.

D‘Antonio, C.M., and Vitousek, P.M., 1992, Biological invasions by exotic grasses, the grass/fire cycle, and global change: Annual Review of Ecology and Systematics, v. 23, p. 63-87.

Dewalt, S.J., Denslow, J.S., Ickes, K., 2004, Natural-enemy release facilitates habitat expansion of the invasive tropical shrub Clidemia hirta: Ecology, v. 85, no. 2, p. 471-483.

Dudley, B.D., Hughes, R.F., Ostertag, R., 2014, Groundwater availability mediates the ecosystem effects of an invasion of Prosopis pallida: Ecological Applications, v. 24: 19541971, available at http://dx.doi.org/10.1890/13-1262.1.

Dukes, J.S., and Mooney, H.A., 1999, Does global change increase the success of biological invaders?: Trends in Ecology and Evolution, v. 14, no. 4, p. 135-139, available at http://dx.doi.org/10.1016/S0169-5347(98)01554-7.

Ehrenfeld, J.G., 2003, Effects of exotic plant invasions on soil nutrient cycling processes: Ecosystems, v. 6, no. 6, p. 503-523.

Ellsworth, L.M., Litton, C.M., Dale, A.P., Miura, T., 2014, Invasive grasses change landscape structure and fire behaviour in Hawaii: Applied Vegetation Science, v. 17, no. 4, p. 680-689, available at http://dx.doi.org/10.1111/avsc.12110.

Elton, C.S., 1958, The Ecology of Invasions by Animals and Plants: London, Methuen, $181 \mathrm{p}$.

Fosberg, F.R., 1937, Immigrant plants in the Hawaiian Islands I: University of Hawai'i Occasional Paper 32, 11 p.

Gallaher, T., and Merlin, M., 2010, Biology and impacts of Pacific Island invasive species. 6. Prosopis pallida and Prosopis juliflora (Algarroba, Mesquite, Kiawe) (Fabaceae): Pacific Science, v. 64, no. 4, p. 489-526, available at http://dx.doi. org/10.2984/64.4.489.
Gon, S.M., III, Allison, A., Cannarella, R.J., Jacobi, J.D., Kaneshiro, K.Y., Kido, M.H., Lane-Kamahele, M., and Miller, S.E., 2006, A GAP analysis of Hawaii-Final Report: U.S. Geological Survey, Research Corporation of the University of Hawai'i, 163 p., plus maps and appendixes.

Hall, S.J., and Asner, G.P., 2007, Biological invasion alters regional nitrogen-oxide emissions from tropical rainforests: Global Change Biology, v. 13, no. 10, p. 2143-2160.

Holdridge, L.R., 1947, Determination of world plant formations from simple climate data: Science, v. 105, p. 367-368.

Hughes, R.F., Asner, G.P., Mascaro, J., Uowolo, A., and Baldwin, J., 2014, Carbon storage landscapes of lowland Hawaii- the role of native and invasive species through space and time: Ecological Applications, v. 24, no. 4, p. 716-731, available at http://dx.doi.org/10.1890/12-2253.1.

Hughes, R.F., and Denslow, J.S., 2005, Invasion by a $\mathrm{N}_{2}$-fixing tree alters function and structure in wet lowland forests of Hawaii: Ecological Applications, v. 15, no. 5, p. 1615-1628.

Hughes, R.F., Johnson, M.T., and Uowolo, A., 2013, The invasive alien tree Falcataria moluccana - its impacts and management, in Johnson, M.T., ed., Proceedings of the 13th International Symposium on Biological Control of Weeds, Waukaloa, Hawai' 'i, September 11-16, 2011: U.S. Forest Service FHTET-2012-07, p. 218-223. [Also available at http://www.invasive.org/publications/xiiisymposium/ Session-5.pdf.]

Hughes, R.F., and Vitousek, P.M., 1993, Barriers to shrub reestablishment following fire in the seasonal submontane zone of Hawai'i: Oecologia, v. 93, no. 4, p. 557-563.

Hughes, R.F., Vitousek, P.M., and Tunison, J., 1991, Alien grass invasion and fire in the seasonal submontane zone of Hawai'i. Ecology, v. 72, no. 2, p. 743-746.

Intergovernmental Panel on Climate Change (Eggleston, H.S., Buendia, L., Miwa, K., Ngara, T., and Tanabe, K., eds.), 2006, 2006 IPCC guidelines for national greenhouse gas inventories: Hayama Japan, Institute for Global Environmental Strategies, prepared by the National Greenhouse Gas Inventories Programme, available at http://www.ipcc-nggip.iges.or.jp/public/2006gl/.

Kirch, P.V., 1982, The impact of prehistoric Polynesians on the Hawaiian ecosystem: Pacific Science, v. 36, no. 1, 1-14.

Lott, J.E., Khan, A.A.H., Black, C.R., Ong, C.K., 2003, Water use in a Grevillea robusta-maize overstorey agroforestry system in semi-arid Kenya: Forest Ecology and Management, v. 180, p. 45-59, available at http://dx.doi. org/10.1016/S0378-1127(02)00603-5. 
Lowe, S., Browne, M., Boudjelas, S., De Poorter, M., 2000, 100 of the World's worst invasive alien species - a selection from the global invasive species database: The Invasive Species Specialist Group, $12 \mathrm{p}$.

MacDougall, A.S., and Turkington, R., 2005, Are invasive species the drivers or passengers of change in degraded ecosystems?: Ecology, v. 86, no. 1, p. 42-55.

Mascaro, J., Hughes, R.F., and Schnitzer, S.A., 2012, Novel forests maintain ecosystem processes after the decline of native tree species: Ecological Monographs, v. 82, no. 2, p. 221-238, available at http://dx.doi.org/10.1890/11-1014.1.

Meyer, J.-Y., 1994, Mecanismes d'invasion de Miconia calvescens en Polynesie Française: Montpellier, France, l'Universite de Montpellier II Sciences et Techniques du Languedoc, Ph.D. dissertation, $122 \mathrm{p}$.

Meyer, J.-Y., 1996, Status of M. calvescens (Melastomataceae), a dominant invasive tree in the Society Islands (French Polynesia): Pacific Science, v. 50, no. 1, p. 66-76.

Mueller-Dombois, D., and Fosberg, F.R., 1998, Vegetation of the tropical Pacific islands: New York, Springer-Verlag, 733 p.

Myers, N., Mittermeier, R.A., Mittermeier, C.G., da Fonseca, G.A.B., and Kent, J., 2000, Biodiversity hotspots for conservation priorities: Nature, v. 403, p. 853-858.

Nanko, K., Giambelluca, T.W., Sutherland, R.A., Mudd, R.G., Nullet, M.A., Ziegler, A.D., 2015, Erosion potential under Miconia calvescens stands on the Island of Hawai' $i$ : Land Degradation \& Development, v. 26, no. 3, p. 218-226, available at http://dx.doi.org/10.1002/ldr.2200.

Nelson, R.E., 1965, A record of forest plantings in Hawaii: Berkeley, California, U.S. Department of Agriculture, Forest Service, Pacific Southwest Forest and Range Experiment Station Resource Bulletin PSW-1, 18 p.

Rothstein, D.E., Vitousek, P.M., Simmons, B.L., 2004, An exotic tree alters decomposition and nutrient cycling in a Hawaiian Montane Forest: Ecosystems, v. 7, no. 8, p. 805-814.

Scowcroft, P.G., Friday, J.B., Idol, T., Dudley, N., Haraguchi, J., and Meason, D., 2007, Growth response of Acacia koa trees to thinning, grass control, and phosphorus fertilization in a secondary forest in Hawai $i$ i: Forest Ecology and Management, v. 239 , p. $69-80$.

Shane, M.W., and Lambers, H., 2005, Cluster roots-A curiosity in context: Plant and Soil, v. 274, p. 101-125.

Skolmen, R.G., 1963, Plantings on the Forest Reserves of Hawaii 1910-1960: Honolulu, Pacific Southwest Forest and Range Experiment Station, Institute of Pacific Islands Forestry, U.S. Department of Agriculture, Forest Service, $441 \mathrm{p}$.
Smith, C.W., 1985, Impacts of alien plants on Hawai'i's native biota, in Stone, C.P. and Scott, J.M., eds., Hawai'i's terrestrial ecosystem - preservation and management: Honolulu, University of Hawai'i at Mānoa, Cooperative National Park Resource Studies Unit, p. 180-250.

Smith, C.W., 1992, Distribution, status, phenology, rate of spread, and management of Clidemia in Hawai' $\mathrm{i}$, in Stone, C.P., Smith, C.W., and Tunison, J.T., eds., Alien plant invasions in native ecosystems of Hawai' $i$ - management and research: Honolulu, University of Hawai'i Press, University of Hawai'i at Mānoa, Cooperative National Park Resources Studies Unit, p. 241-253.

Smith, C.W., and Tunison, J.T., 1992, Fire and alien plants in Hawai' $i$ - research and management implications for native ecosystems in Stone, C.P., Smith, C.W., and Tunison, J.T., eds., Alien plant invasions in native ecosystems of Hawai ' ${ }^{\circ}$ - management and research: Honolulu, University of Hawai'i Press, University of Hawai'i at Mānoa, Cooperative National Park Resources Studies Unit, p. 394-408.

Trauernicht, C., Pickett, E., Giardina, C.P., Litton, C.M., Cordell, S., and Beavers, A., 2015, The contemporary scale and context of wildfire in Hawai' 1 : Pacific Science, v. 69 , no. 4 , p. $427-444$, available at http://dx.doi. org/10.2984/69.4.1.

Vitousek, P.M., 1990, Biological invasions and ecosystem processes - towards an integration of population biology and ecosystem studies: Oikos, v. 57, p. 7-13.

Vitousek, P.M., D'Antonio, C.M., Loope, L.L., and Westbrooks, R., 1996, Biological invasions as global environmental change: American Scientist, v. 84, p. 468-478.

Vitousek, P.M., D'Antonio, C.M., Loope, L.L., Rejmanek, M., Westbrooks, R., 1997, Introduced species-A significant component of human-caused global change: New Zealand Journal of Ecology, v. 21, no. 1, p. 1-16.

Vitousek, PM, and Farrington, H., 1997, Nutrient limitation and soil development-Experimental test of a biogeochemical theory: Biogeochemistry, v. 37, no. 1, p. 63-75.

Vitousek, P.M., Loope, L.L., Stone, C.P., 1987, Introduced species in Hawaii-biological effects and opportunities for ecological research: Trends in Ecology and Evolotion, v. 2, no. 7, p. 224-227.

Vitousek, P.M., and Walker, L.R., 1989, Biological invasion by Myrica faya in Hawai'i-Plant demography, nitrogen fixation, ecosystem effects: Ecological Monographs, v. 59, no. 3, p. 247-265. 
Vitousek, P.M., Walker, L.R., Whiteaker, L.D., Matson, P.A., 1993, Nutrient limitations to plant growth during primary succession in Hawaii Volcanos National Park: Biogeochemistry, v. 23, no. 8, p. 197-215.

Vitousek, P.M., Walker, L.R., Whiteaker, L.D., MuellerDombois, D., Matson, P.A., 1987, Biological invasion by Myrica faya alters ecosystem development in Hawaii: Science, v. 238 p. 802-804.

Wagner, W.L., Herbst, D.R., and Sohmer, S.H., 1999, Manual of the Flowering Plants of Hawai'i (2d ed.): Honolulu, University of Hawai'i Press, Bishop Museum Press, $1,919 \mathrm{p}$.
Whiteaker, L.D., Gardner, D.E., 1985, The distribution of Myrica faya Ait. in the State of Hawai' $i$ : University of Hawai' $i$ at Mānoa, Cooperative National Park Resources Studies Unit Technical Report 55, $31 \mathrm{p}$.

Woodcock, D., 2003, To restore the watersheds - Early twentiethcentury tree planting in Hawai' $\mathrm{i}$ : Annals of the Association of American Geographers, v. 93, no. 3, p. 624-635.

Zimmerman, N., Hughes, R.F., Cordell, S., Hart, P., Chang, H.K., Perez, D., Like, R.K., and Ostertag, R., 2008, Patterns of primary succession of native and introduced plants in lowland wet forests in eastern Hawai' $i$ i: Biotropica, v. 40, no. 3, p. 277-284. 



\title{
Chapter 5. Wildland Fires and Greenhouse Gas Emissions in Hawai'i
}

\author{
By Todd J. Hawbaker, ${ }^{1}$ Clay Trauernicht, ${ }^{2}$ Stephen M. Howard, ${ }^{1}$ Creighton M. Litton, ${ }^{2}$ Christian P. Giardina, ${ }^{3}$ James D. Jacobi, \\ Lucas B. Fortini, ${ }^{1}$ R. Flint Hughes, ${ }^{3}$ Paul C. Selmants, ${ }^{1}$ and Zhiliang Zhu ${ }^{1}$
}

\subsection{Highlights}

- Across the islands of Hawai'i, Maui, Moloka'i, $\mathrm{O}^{\prime}$ 'ahu, and Kaua'i the annual area burned by large wildland fires $\left(\geq 0.4 \mathrm{~km}^{2}\right.$ burned) between 2002 and 2011 averaged $48 \mathrm{~km}^{2} / \mathrm{yr}$ and ranged between 5 and $119 \mathrm{~km}^{2} / \mathrm{yr}$.

- For the same period, greenhouse gas emissions from wildland fires averaged $0.0271 \mathrm{TgC} / \mathrm{yr}$ $\left(0.0942 \mathrm{TgCO}_{2}\right.$-eq/yr) and ranged from 0.0016 to $0.0637 \mathrm{TgC} / \mathrm{yr}\left(0.0055\right.$ to $0.2202 \mathrm{TgCO}_{2}$-eq/yr).

- Average annual wildland fire emissions from 2002 to 2011 were equivalent to 0.5 percent of 2011 fossil-fuel emissions in Hawai'i (5.8 TgC/yr or $21.2 \mathrm{TgCO}_{2}$-eq/yr).

- Most of the area burned was in grassland (51 percent) and dry shrubland (22 percent) ecosystems.

- The potential for future increases in carbon storage in Hawaiian ecosystems is limited by fire and its controls on the recovery of forest vegetation in fire-prone nonnative shrublands and grasslands and the loss of forest vegetation when fire converts these systems to nonnative shrublands and grasslands after fires.

\subsection{Introduction}

Restoring, protecting, and maintaining functional ecosystems that can continue to sequester $\mathrm{CO}_{2}$ from the atmosphere offers a powerful set of tools for mitigating climate change, which, paired with policies and regulations, can serve to directly offset anthropogenic greenhouse gas emissions. The energy budgets of ecosystems are controlled by albedo, evapotranspiration, and resulting changes to solar heating and water balance. These drivers, in turn, regulate ecosystem capacity to fix and retain carbon, and so modify

${ }^{1}$ U.S. Geological Survey.U.S. Department of Agriculture Forest Service.

${ }^{2}$ University of Hawai'i i at Mānoa.

${ }^{3}$ U.S. Department of Agriculture Forest Service. atmospheric $\mathrm{CO}_{2}$ concentrations (Bonan, 2008). The total amount of carbon entering ecosystems through the process of photosynthesis is gross primary production (GPP). The difference between GPP and carbon losses from autotrophic and heterotrophic respiration is net ecosystem production (NEP) or net ecosystem carbon balance (NECB) when additional carbon losses from disturbances and lateral fluxes are also considered (Chapin and others, 2006). When NECB is positive, carbon is sequestered from the atmosphere and stored in ecosystem carbon stocks, potentially offsetting anthropogenic greenhouse gas emissions (for example, fossil fuel combustion and other emissions).

Global estimates of greenhouse gas emissions in 2011 from fossil fuel combustion, cement production, and gas flares were $9.5 \pm 0.8 \mathrm{PgC} / \mathrm{yr}$; forestry, wildland fires, and land-use change accounted for additional emissions of $0.9 \pm 0.8 \mathrm{PgC} / \mathrm{yr}$ from 2002 to 2011 (Intergovernmental Panel on Climate Change [IPCC], 2014). Approximately 40 percent of anthropogenic emissions from 1750 to 2011 have remained in the atmosphere where they increase atmospheric radiative forcing. The remaining 60 percent of anthropogenic emissions during this same period are thought to have been absorbed by ocean and vegetation carbon sinks (IPCC, 2014).

The amount of carbon stored and sequestered by specific ecosystem types varies widely (Whittaker and Likens, 1973; Bonan, 2008). Globally, forest ecosystems contain nearly 45 percent of all carbon stored in terrestrial ecosystems and account for nearly 50 percent of all carbon sequestered by ecosystems (Bonan, 2008). However, savannas, shrublands, and grasslands can also be highly productive (Lieth, 1973; Whittaker and Likens, 1973), and because of their large areal extent, non-forest ecosystems hold a large proportion of global carbon stocks (Bonan, 2008). For instance, temperate grasslands store $6 \mathrm{PgC}$ and sequester 5.6 PgC/yr globally (Saugier and others, 2001). Among forests, tropical forests tend to store and sequester more carbon than other ecosystems $(471 \pm 93 \mathrm{PgC}$ and $1.02 \pm 0.47 \mathrm{PgC} /$ $\mathrm{yr}$, respectively [Pan and others, 2011]), even though they cover only 12 percent of the ice-free terrestrial surface area (Bonan, 2008). Boreal forests and temperate forests also have large carbon stocks (282 $\pm 22.5 \mathrm{PgC}$ and $118.6 \pm 6.3 \mathrm{PgC}$, respectively) and contribute substantially to global net primary production (NPP) $(0.5 \pm 0.08 \mathrm{PgC} / \mathrm{yr}$ and $0.72 \pm 0.08 \mathrm{PgC} / \mathrm{yr}$, respectively) (Pan and others, 2011). In certain cases, carbon stored in and sequestered 
by temperate forests can be as great or greater than boreal and tropical forests (Keith and others, 2009).

Hawai' $i$ is climatically, and as a result biogeographically, very diverse because of the remarkably steep elevation and precipitation gradients created by fixed zones of uplift on windward slopes found across the main islands of the Hawaiian archipelago (Giambelluca and others, 2013). As a result of these gradients, Hawai' $i$ provides a unique opportunity to understand the effects of climate, land-use, and land-cover change on carbon storage and flux. Land cover in Hawai' $i$ is approximately 12 percent developed and agriculture, 19 percent barren or sparse vegetation on lava flows and alpine areas, and 69 percent natural and managed ecosystems (forests, shrublands, and grasslands). Approximately 36 percent $\left(6,000 \mathrm{~km}^{2}\right)$ of the land area in the main Hawaiian Islands is dominated by forest, of which 15 percent is classified as alien and (or) mixed forest, 1 percent is classified as alien tree plantation, and 20 percent is classified as native forest (Jacobi and others, this volume, chap. 2). Because these ecosystems cross wide topographic and climatic gradients, Hawai' $i$ is home to a tremendous diversity of biome types with some ecosystems supporting high carbon densities and others capable of sequestering large quantities of carbon from the atmosphere (Aplet and Vitousek, 1994; Raich and others, 1997; Schuur and others, 2001; Ziegler, 2002; Litton and Kauffman, 2008; Asner and others, 2009; Vitousek and others, 2009).

The largest changes in aboveground carbon stocks in Hawai' $i$ likely occurred within the past century when large areas of dry, mesic, and even wet forest were converted to ranchlands and plantation agriculture. A portion of these converted lands have since been abandoned, and the resulting nonnative shrublands and grasslands currently represent 33 percent of terrestrial ecosystem land cover. In the past three decades (1980-2010), decreases in agricultural production across Hawai' $i$ have further increased the flammability of Hawai'i's landscapes (Trauernicht and others, 2015). These wildland fire-prone novel ecosystems greatly increase the potential for wildland fire impacts in adjacent forests, threatening the stability of carbon stocks.

For the purposes of this assessment, we define wildland fires as fires that burned wildland vegetation and were ignited by natural causes (for example, lightning and volcanoes) or by humans (arson or accidental ignitions). Globally, wildland fires are a critical driver of the carbon cycle because they consume biomass through combustion resulting in an immediate release of greenhouse gases including $\mathrm{CO}_{2}, \mathrm{CO}$, and $\mathrm{CH}_{4}$ (Seiler and Crutzen, 1980). Wildland fires can also impact carbon cycling after combustion, by transferring biomass from live to dead pools, through decomposition of dead vegetation, but more so by influencing the establishment of new vegetation that can result in years to decades before carbon stocks return to pre-wildland fire conditions (Turner and others, 1998; Cleary and others, 2010; Hurteau and Brooks, 2011; Kashian and others, 2013). However, if wildland fires completely change the vegetation community that regrows in the post-wildland fire environment (for example, converting forest to grassland), then the impact on the carbon cycle will be large and long lasting (Bachelet and others, 2001). This type of potential impact is particularly important in Hawai' $i$, where novel wildland fire cycles have become established with invasion by nonnative grasses that create and allow grasslands to persist, ensuring the continuation of the wildland-nonnative-grass fire cycle.

Wildland fires are thought to have been historically infrequent and to have had a small impact on most native Hawaiian ecosystems (and carbon cycling) relative to present day conditions. Before European contact, natural ignition sources were relatively rare, but Hawaiians likely used fire to clear native vegetation for agriculture or to promote growth of pili grass (Heteropogon contortus) which was used to thatch houses (Cuddihy and Stone, 1990). Hawai'i's native wildland fire regime was radically transformed with the introduction of wildland fire-prone and wildland fire-adapted nonnative grasses and shrubs (D'Antonio and Vitousek, 1992) and an increase in ignition sources from human activities (Trauernicht and others, 2015). Today, these nonnative shrubs and grasses and continued anthropogenic ignition sources drive a novel wildland fire disturbance regime, with a particularly large influence on carbon storage because invasion ultimately carries wildland fire that kills woody plants and consumes carbon stored in woody biomass (Ellsworth and others, 2014). The resulting nonnative grasslands have a much lower capacity to store carbon, and this limited capacity is further reduced by frequently recurring wildland fires. Nonnative grasses including Cenchrus clandestinus (kikuyu grass), Cenchrus setaceus (fountain grass), Melinus minutiflora (molasses grass), and Megathyrsus maximus (guinea grass) were originally introduced in the late 1800s and early 1990s for animal forage or as ornamentals and have since spread widely throughout dry-to-mesic and even wet areas of Hawai' $i$, particularly those areas that have been disturbed by human activities such as ranching and agriculture (Cuddihy and Stone, 1990). Wildland fire-adapted and -promoting nonnative shrubs include Leucaena leucocephala (haole koa), Schinus terebinthifolia (Christmasberry), and Ulex europaeus (European gorse). In areas where the nonnative grasses are established, regeneration of native trees is commonly limited because of competition for limiting resources (Hughes and others, 1991; Litton and others, 2006), but also because cattle and other nonnative ungulates consume native seedlings and saplings which evolved without large mammalian herbivores present (Cole and Litton, 2014). Further, rodents like black rats reduce available seed for regeneration by consuming fruits (Shiels and Drake, 2011). Cattle grazing in Hawai' $i$ has decreased by more than 60 percent within the past several decades (from 850,000 ha to 324,000 ha between 1960 and 2012 [Trauernicht and others, 2015]) and in the absence of grazing, grass fuel loads accumulate and the risk of severe wildland fires increases (Elmore and others, 2005; Evans and others, 2015), which, in turn, results in an additional loss of native forest and further promotes nonnative grasses (Hughes and others, 1991; Blackmore and Vitousek, 2000; Litton and others, 2006). This nonnative grass wildland fire cycle perpetuates the conditions necessary for future potential 
wildland fires to spread into adjacent shrubland and forests where they can drive additional vegetation-type conversions and carbon losses to the atmosphere.

The drivers of wildland fire occurrence in Hawai' $i$ are different than those in other parts of the United States. Like many parts of the world, wildland fire occurrence in Hawai' $i$ has been linked to drought, which can intensify during El Niño events (Dolling and others, 2005; Chu and others, 2002). However, long-term records indicate that the four-fold increase in annual area burned in Hawai' $i$ within the past century is primarily related to human activity (Trauernicht and others, 2015). Given the scarcity of dry lightning strikes in Hawai' $i$, nearly all wildland fires in Hawai' $i$ outside of active volcanic areas are human caused, and the introduction and expansion of wildland fire-prone plants with changes in land use has greatly increased the potential for wildland fire occurrence and spread. Based on spatial analyses of point-based wildland fire records, wildland fire ignitions are most prevalent in developed areas, indicating humans are the prime cause of wildland fire occurrence; most large wildland fires occur in nonnative shrublands and grasslands in the drier, leeward parts of the state (Trauernicht and others, 2015), indicating nonnative grasses are the prime cause of wildland fire spread.

Wildland fires are important to consider in assessments of carbon cycling in Hawai' $i$ because they produce greenhouse gas emissions as well as changing vegetation types, carbonflux rates, and carbon-storage potential. The importance of wildland fire in driving land-cover conversions in Hawaiian ecosystems and the potential drivers influencing when and where wildland fires occur in Hawai' $i$ are well understood and documented in existing research. What is less understood are the impacts of wildland fire on carbon emissions across space and time in the Hawaiian Islands. Thus, this chapter focuses on quantifying (1) temporal patterns of area burned and greenhouse gas emissions by wildland fires for the State of Hawai' $i$ for the baseline period of 2002 through 2011, and (2) the implications of wildland fire-induced shifts in vegetation cover on carbon storage. Long-term effects of fires on carbon stocks in vegetation are assessed in Sleeter and others (this volume, chap. 8).

\subsection{Input Data and Methods}

The approach for this analysis included several steps:

(1) estimating annual area burned for Hawai'i using satellitederived data to determine the spatial extent of wildland fire incidents and to characterize patterns of burn severity, (2) developing a database of biomass loads for different vegetation types from existing studies, (3) linking values from the biomass data to a satellite-derived land-cover classification, (4) combining the raster burn-severity data with the land-cover data to estimate annual area burned by vegetation type, and (5) estimating biomass consumption and fire emissions using the combination of the burn severity with land-cover classes and their associated biomass loads. The individual steps in this analysis and the data they depended on are described in the following sections.

\subsubsection{Wildland Fire Occurrence and Severity Data}

Limited wildland fire perimeter data exist for the State of Hawai' $i$ to quantify the extent and frequency of wildland fires in different vegetation types. For example, the Monitoring Trends in Burn Severity (MTBS) database only contains 11 perimeters for Hawai' $i$ from the years 2002 to 2011 (Eidenshink and others, 2007), however, point locations of wildland fire ignitions are routinely recorded by State and Federal agencies (Pierce and Pickett, 2014). For the wildland fire component of this assessment, a new database was developed of burned areas with severity for wildland fires $\geq 100$ acres $\left(0.4 \mathrm{~km}^{2}\right)$. Points of reported wildland fire locations from 2002 to 2011 were gathered from State and Federal agencies in Hawai' ${ }^{i}$ (Hawai'i Wildfire Management Organization, 2013) and from the Short (2014) wildland fire occurrence database. These points were compared with points in the MTBS data and were removed if they had existing MTBS perimeters. This resulted in a total of 146 points, of which 135 lacked corresponding MTBS perimeters. At each point without an existing perimeter, Landsat 7 satellite imagery was visually examined for evidence of burned areas. If the burned area was visible in the Landsat imagery, burn severity was mapped following MTBS protocols (Eidenshink and others, 2007). After Landsat image interpretation, burned areas were found for 82 of the original 135 wildland fire points that did not have existing MTBS perimeters. An additional 11 wildland fires that were not reported were also found. Of the 53 wildland fire points not associated with burned areas visible in the Landsat images, 5 appeared to be duplicates. No visible burned areas were found for the other 48 points. No wildland-fire data existed for the islands of Kaho'olawe, Lāna' $i$, and $\mathrm{Ni}^{\text {' }}$ 'hhau, so they were excluded from this analysis. The final wildland-fire database contained perimeters and severity information for more than 104 wildland fires $\geq 100$ acres $\left(0.4 \mathrm{~km}^{2}\right)$ between 2002 and 2011 (fig. 5.1), which formed the basis for analyses of wildland fires in this assessment.

\subsubsection{Land-Cover Data}

Spatial data depicting vegetation types for Hawai' $i$ were required to estimate emissions. For this analysis and other components of the carbon assessment of Hawai' $i$, a simplified version of the carbon assessment for Hawai' $\mathrm{i}(\mathrm{CAH})$ land-cover map combined with moisture zones was used (fig. 5.2; Jacobi and others, this volume, chap. 2). These data were generated by reducing the $\mathrm{CAH}$ land-cover map to the following land-cover classes: forest, shrubland, grassland, wetland, developed, and agriculture. These classes were then subdivided using moisture-zone data from Jacobi and others (this volume, chap. 2). For instance, forest classes were split into dry, mesic, or wet. Classes were further refined to represent vegetation classes where enough field-based information from previous studies was available to assign biomass fuel loads (see section 5.3.3). Burn-severity information from the wildlandfire database was combined with spatial information delineating the different land-cover classes. A few burned pixels were located in anthropogenic (developed), wetland, and open-water land-cover 


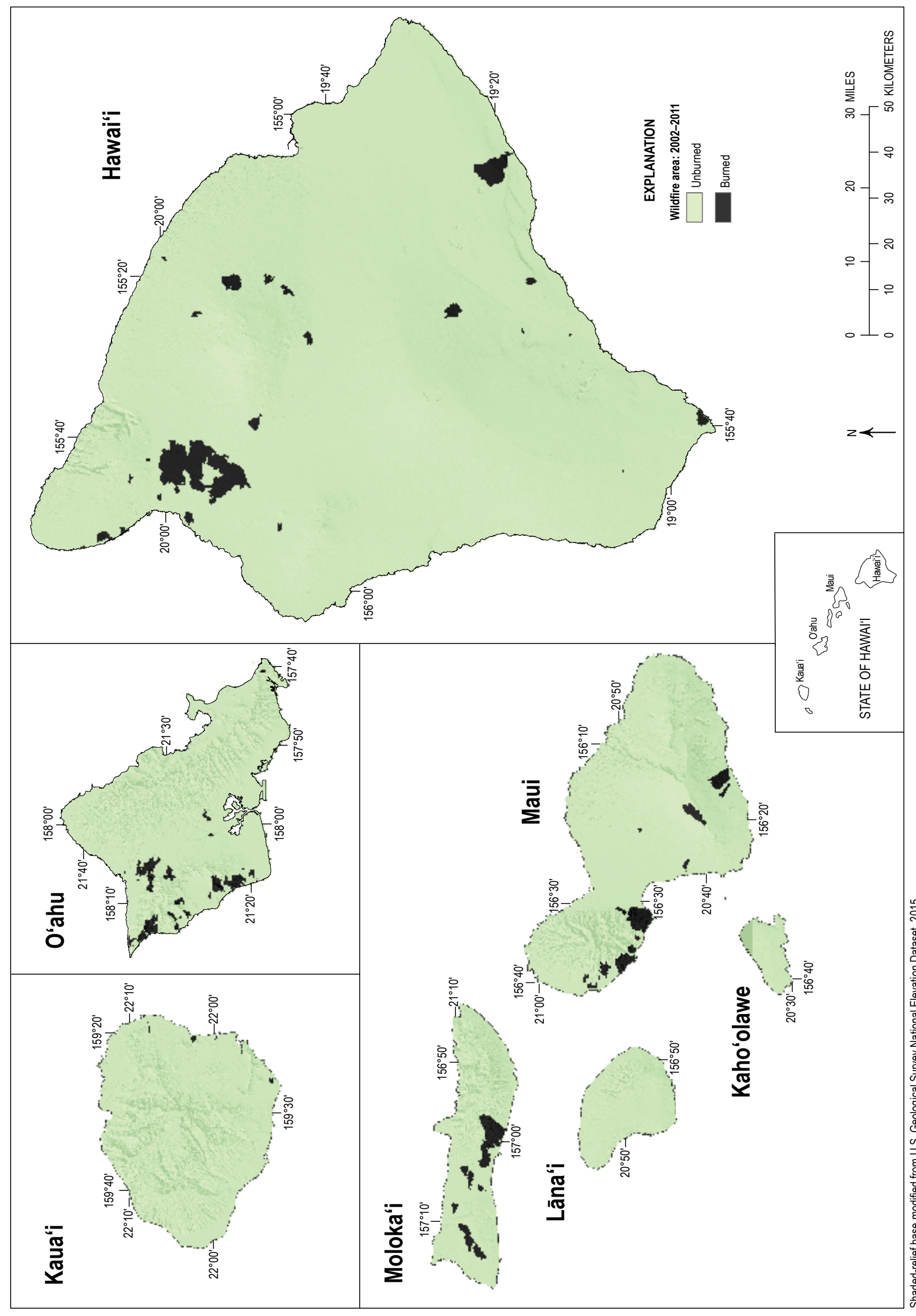

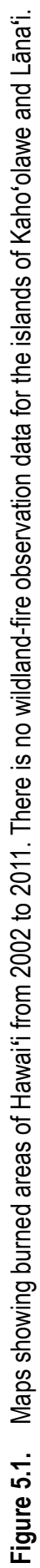




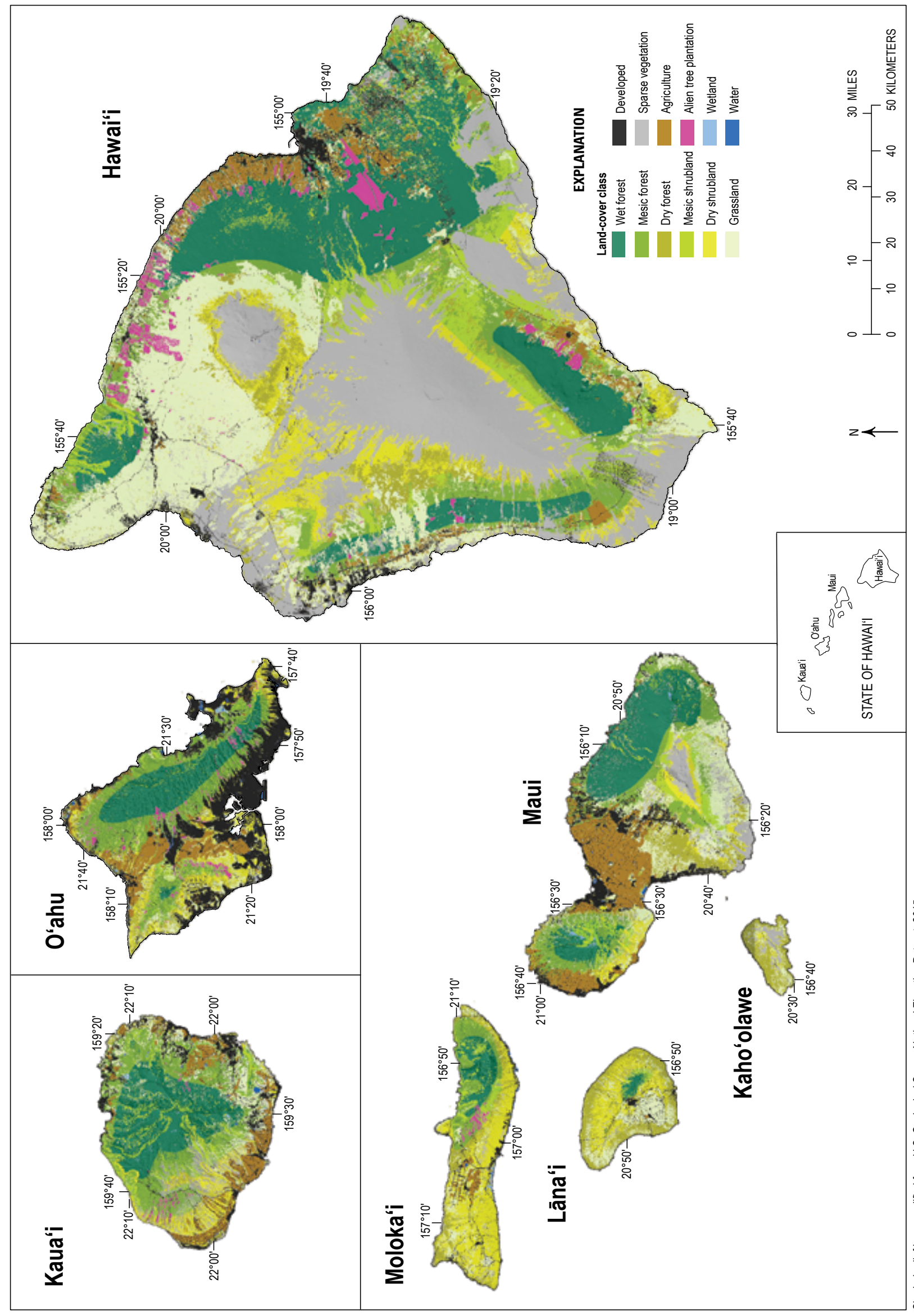


categories. This was most likely a result of errors in the land-cover classification and those burned pixels were removed prior to analysis.

\subsubsection{Pre-Wildland Fire Biomass Data}

Estimating biomass consumption and fire emissions required pre-wildland fire biomass levels specific to individual vegetation classes. To meet this need, a database of biomass measurements from field data gathered across Hawai' $i$ was compiled. Data were gathered from existing published and unpublished studies (table 5.1) with a focus on shrubland and grassland ecosystems because these systems experience most of the wildland fires, have highly variable biomass loads, and are poorly represented in existing biomass and fuels databases used for wildland fire behavior and emissions modeling (for example, LANDFIRE; Rollins, 2009). Biomass component names were used inconsistently across the different studies and required normalization to a common naming scheme. For

Table 5.1. Studies from which biomass data were compiled for this assessment.

Ainsworth, A., and Kauffman, J.B., 2010, Interactions of fire and nonnative species across an elevation/plant community gradient in Hawaii Volcanoes National Park: Biotropica, v. 42, no. 6, p 647-655, available at http://dx.doi.org/10.1111/j.1744-7429.2010.00636.x.

Ansari, S., Hirsh, H., and Thair, T., 2008, Removal of invasive fire-prone grasses to increase training lands in the Pacific: Department of Defense Legacy Project \#07-362.

Beavers, A., Burgan, R., Fujioka, F., Laven, R., and Omi, P., 1999, Analysis of wildland fire management concerns at Makua Military Reservation: Fort Collins, Colo., Center for Environmental Management of Military Lands.

Beavers, A., Unpublished biomass data from Dole Plantation, Helemano, O`ahu.

Beavers, A., Unpublished biomass data from Keamuku, Hawai'i.

Beavers, A., Unpublished biomass data from Schofield Barracks.

Blackmore, M., and Vitousek, P.M., 2000, Cattle grazing, forest loss, and fuel loading in a dry forest ecosystem at Pu'u Wa'aWa'a Ranch, Hawai'i: Biotropica, v. 32, no. 4a, p. 625-632.

Castillo, J.M., Enriques, G., Nakahara, M., Weise, D., Ford, L., Moraga, R., and Vihnanek, R., 2007, Effects of cattle grazing, glyphosphate, and prescribed burning on fountain grass fuel loading in Hawai' $i$, in Masters, R.E., and Galley, K.E.M., eds., Proceedings of the 23rd Tall Timbers Fire Ecology Conference-Fire in Grassland and Shrubland Ecosystems: Tallahassee, Fla.,Tall Timbers Research Station, p. 230-239. [Also available at http://talltimbers. org/tall-timbers-fire-ecology-conference-proceedings-volume-23/.]

Ellsworth, L.M., Litton, C.M., Taylor, A.D., and Kauffman, J.B., 2013, Spatial and temporal variability of guinea grass (Megathyrsus maximus) fuel loads and moisture on Oahu, Hawaii: International Journal of Wildland Fire, v. 22, no. 8, p. 1083-1092, available at http://dx.doi.org/10.1071/WF12051.

Freifelder, R.R., Vitousek, P.M., and D’Antonio, C.M., 1998, Microclimate change and effect on fire following forest-grass conversion in seasonally dry tropical woodland: Biotropica, v. 30, no. 2, p. 286-297.

Fujioka, F.M., and Fujii, D.M., 1980, Physical characteristics of selected fine fuels in Hawaii-some refinements on surface area-to-volume calculations: Berkeley, Calif., U.S. Department of Agriculture, Forest Service, Pacific Southwest Forest and Range Experiment Station, Research Note PSW-348, $7 \mathrm{p}$.

Iwashita, D.K., Litton, C.M., and Giardina, C.P., 2013, Coarse woody debris carbon storage across a mean annual temperature gradient in tropical montane wet forest: Forest Ecology and Management, v. 291, p. 336-343, available at http://dx.doi.org/10.1016 /j.foreco.2012.11.043.

Litton, C.M., Sandquist, D.R., and Cordell S., Unpublished biomass data for Kaupulehu Dry Forest. [See Litton and others (2006) for a description of the study site.]

Litton, C.M., Sandquist, D.R., and Cordell, S., 2006, Effects of non-native grass invasion on aboveground carbon pools and tree population structure in a tropical dry forest of Hawaii: Forest Ecology and Management, v. 231, no. 1-3, p. 105-113.

Litton, C.M., Ainsworth, A., and Kauffman, J.B., Unpublished biomass data for Hawaii Volcanoes National Park [See Ainsworth and Kauffman (2010) for a description of study site.]

McDaniel, S., and Ostertag, R., 2010, Strategic light manipulation as a restoration strategy to reduce alien grasses and encourage native regeneration in Hawaiian mesic forests: Applied Vegetation Science, v. 13, p. 280-290, available at http://dx.doi.org/10.1111/j.1654-109X.2009.01074.x.

Pierce, A., Giardina, C.P., and Litton, C.M., Unpublished biomass data for Pohakuloa Training Area, Hawaii Island.

Schuur, E.A.G., Chadwick, O.A., and Matson, P.A., 2001, Carbon cycling and soil carbon storage in mesic to wet Hawaiian montane forests: Ecology, v. 82, no. 11, p. 3182-3196.

Selmants, P.C., Litton, C.M., Giardina, C.P., and Asner, G.P., 2014, Ecosystem carbon storage does not vary with mean annual temperature in Hawaiian tropical montane wet forests: Global Change Biology, v. 20, no. 9, p. 2927-2937, available at http://dx.doi.org/10.1111/gcb.12636.

Wright, C.S., Ottmar, R.D., Vihnanek, R.E., and Weise, D.R., 2002, Stereo Photo Series for Quantifying Natural Fuels: Grasslands, Shrubland, Woodland, and Forest Types in Hawaii: Portland, Oreg., U.S. Department of Agriculture, Forest Service Pacific Northwest Research Station General Technical Report PNW-GTR-545, 91 p. 
reporting purposes in this study, biomass pools were grouped into the following categories: (1) Duff and Litter, (2) Small Downed Woody Debris (DWD_-Small), (3) Large Downed Woody Debris (DWD_Large), (4) Grass and Herbaceous, and (5) Standing Live Trees. The two downed woody debris classes were defined based on the diameter of logs: large downed woody debris included any logs with 7.6-cm (3-inch) diameter and greater, everything else was considered small downed woody debris. All biomass values were converted from reported units to kilograms of carbon per square meter using a 0.47 biomass-to-carbon conversion factor (Litton and others, 2006). Ultimately, biomass data for 419 plots at 204 different sites were collected from the 19 different studies (table 5.1). Unless there was clear indication that measurements represented different vegetation types, all biomass measurements were averaged to the site level for each study.

Coordinates for individual plot locations were gathered when possible and combined with the land-cover raster data to crosswalk the plot data to different land-cover classes. Expert opinion was used to assign the plot to a land-cover class when plot locations were not available or when the vegetation composition and structure described by the study did not match the land-cover class in the raster data at the plot location. The expert-opinion vegetationstate-class assignment was based on published descriptions of the dominant vegetation types and the authors' familiarity with the vegetation at the study area where the data were collected.

Land-cover classes were further simplified because there were a limited number of plots representing certain vegetation classes in the biomass database. For a given vegetation type (for example, shrubland), plots in the biomass databases tended to fall within one invasion status or another (native versus invaded). Therefore, invasion status was removed from all land-cover classes. In general, the grassland class was primarily invaded and other vegetation classes were primarily native.

\subsubsection{Biomass Consumption and Wildland Fire Emissions}

Biomass consumption and emission rates were generated using the First-Order Wildland Fire Effects Model (FOFEM) (Reinhardt and others, 1997) for each vegetation class and burn-severity category using the information on wildland fire perimeters by vegetation class and the pre-fire biomass loads described above. The FOFEM uses biomass loads along with fuel moistures to estimate the amount of litter and downed woody debris consumed during combustion (Albini and others, 1995; Albini and Reinhardt, 1995; Albini and Reinhardt, 1997). In the FOFEM, the consumption of duff (decaying litter), trees, plants, and shrubs is estimated as a function of the land cover class, season, fuel moistures, and biomass loads. Canopy fuel consumption is estimated as a function of the burn severity provided by the MTBS data: 50 percent for high severity, 30 percent for moderate severity, and 10 percent for low and very low severity. The emissions of $\mathrm{CO}_{2}, \mathrm{CO}$, and $\mathrm{CH}_{4}$ were then calculated on the basis of the amount of fuel consumed, the organic-matter content of the fuel, and how efficiently it burned. The required input data for FOFEM included biomass loads, burn severity, and deadand live-fuel moistures. To simplify the reporting of results, emission estimates were summarized for all carbon-containing constituents to units of carbon and units of $\mathrm{CO}_{2}$-equivalents $\left(\mathrm{CO}_{2}\right.$-eq) using their 100-year global warming potentials (IPCC, 2007) and the following equation:

$$
\mathrm{CO}_{2} \text {-eq }=\mathrm{CO}_{2}+(2.33 \times \mathrm{CO})+\left(21.0 \times \mathrm{CH}_{4}\right)
$$

Three different fuel moisture levels (very low, low, and moderate) were used to generate biomass consumption and emission estimates with FOFEM, corresponding to different burn severities (high, moderate, and low; table 5.2). Variability in biomass consumption and emissions across fuel moisture levels were largely related to the proportion of canopy fuels, woody debris, and litter and duff consumed. The amount of shrub and grass fuels tended to vary little across the moisture level range because these are estimated using fixed proportions of biomass components in FOFEM. Final FOFEM-based estimates for biomass consumption and emission rates by vegetation class, burn-severity class, and biomass pools are shown in table 5.6. Values from this table were multiplied by the area burned in each vegetation class and year to produce estimates of the annual area burned and emissions. Reported results include annual area burned and emissions (total and by vegetation class).

Table 5.2. Fuel moisture levels and values used to estimate biomass consumption and emissions for different land-cover classes.

\begin{tabular}{lccc}
\hline \multirow{2}{*}{ Parameter } & \multicolumn{3}{c}{ Fuel moisture level (percent) } \\
\cline { 2 - 4 } & Very low & Low & Moderate \\
\hline 10-hour fuel moisture & 4 & 7 & 10 \\
1,000-hour fuel moisture & 6 & 9 & 12 \\
Duff fuel moisture & 30 & 60 & 90 \\
Canopy consumption & 50 & 30 & 10 \\
\hline
\end{tabular}




\subsection{Results}

Between 2002 and 2011, across five of the main islands of Hawai'i (excluding Kaho'olawe, Lāna'i, and Ni'ihau), the average annual area burned by large wildland fires $\left(\geq 0.4 \mathrm{~km}^{2}\right.$ burned) was $48 \mathrm{~km}^{2} / \mathrm{yr}$ (fig. $5.3 A$ ). The amount of area that burned in any given year fluctuated widely, ranging from $5 \mathrm{~km}^{2}$ in 2004 to $119 \mathrm{~km}^{2}$ in 2007. The grassland vegetation class had the greatest percentage of its area burned annually ( 0.85 percent/yr), followed by dry shrublands ( 0.72 percent/yr), then dry forests ( 0.35 percent/yr), and mesic shrublands $(0.24$ percent/yr). Other vegetation classes tended to have a smaller percentage of their total area burned each year (table 5.3). The percentage of available area of a vegetation class that burned in a given year was also highly variable and that variability tended to increase with the average annual percentage of a vegetation class that burned. For example, grasslands had the highest variability in the annual percentage of area burned and wet forests had the lowest (table 5.4). On a per-unit-area basis, forest vegetation classes contained the greatest amount of biomass (all pools combined; fig. 5.4). Wet forests had the most biomass with $11.7 \mathrm{kgC} / \mathrm{m}^{2}$, followed by mesic forests with $10.8 \mathrm{kgC} / \mathrm{m}^{2}$, and then dry forests with $5.2 \mathrm{kgC} / \mathrm{m}^{2}$. Other, non-forest land-cover classes had less biomass, typically less than $1 \mathrm{kgC} / \mathrm{m}^{2}$ (fig. 5.4). Similarly, total carbon stored in non-forest land-cover classes was low (7 percent of total carbon stocks) even though non-forest landcover classes cover much more than 7 percent of land in Hawai' $i$. Forests cover 36 percent of Hawai' $i$ land, but hold 93 percent of all carbon in terrestrial ecosystems (table 5.5).

Table 5.3. Annual percentage of area burned by vegetation class from 2002 to 2011 across the main Hawaiian Islands, excluding Kaho'olawe, Lāna'i, and Ni'ihau.

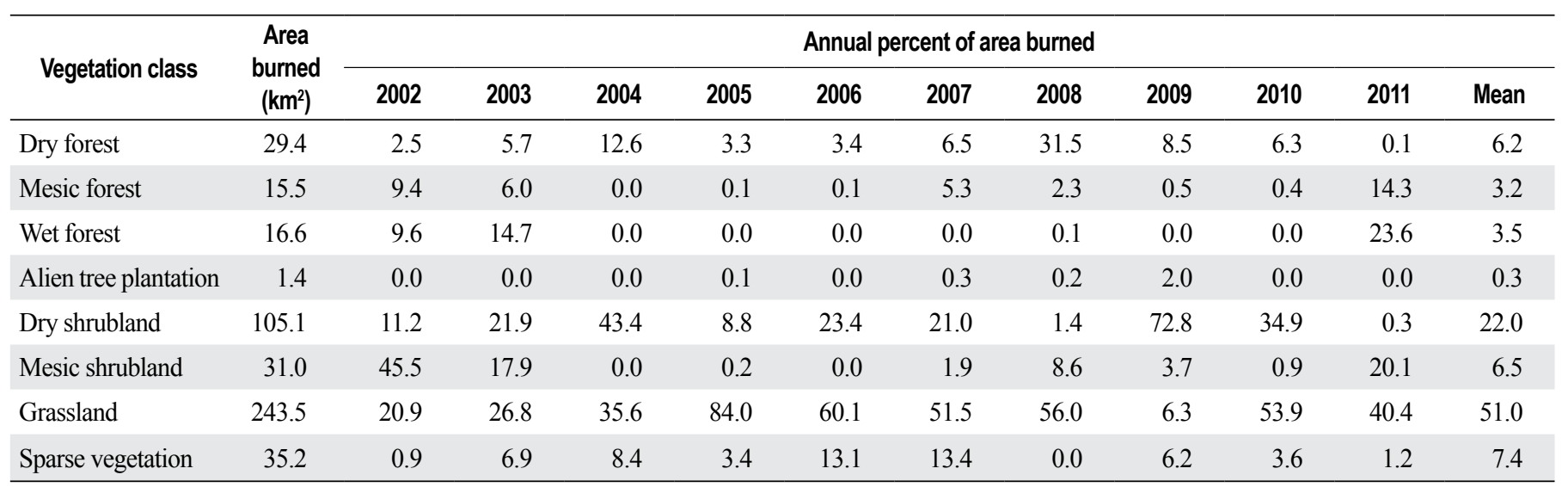

Table 5.4. Annual percentage area of each vegetation class that burned from 2002 to 2011 across the main Hawaiian Islands, excluding Kaho'olawe, Lāna'i, and Ni'ihau.

\begin{tabular}{|c|c|c|c|c|c|c|c|c|c|c|c|c|}
\hline Vegetation class & $\begin{array}{l}\text { Total } \\
\text { area } \\
\left(\mathbf{k m}^{2}\right)\end{array}$ & \multicolumn{11}{|c|}{ Annual percent of vegetation class burned } \\
\hline Dry forest & 812 & 0.0563 & 0.5642 & 0.0769 & 0.4758 & 0.1771 & 0.9620 & 0.6969 & 0.4116 & 0.2017 & 0.0009 & 0.3624 \\
\hline Mesic forest & 1,720 & 0.0985 & 0.2842 & 0.0000 & 0.0039 & 0.0026 & 0.3651 & 0.0242 & 0.0110 & 0.0061 & 0.1060 & 0.0902 \\
\hline Wet forest & 3,221 & 0.0539 & 0.3694 & 0.0000 & 0.0001 & 0.0000 & 0.0000 & 0.0006 & 0.0000 & 0.0000 & 0.0930 & 0.0517 \\
\hline Alien tree plantation & 258 & 0.0000 & 0.0066 & 0.0000 & 0.0620 & 0.0000 & 0.1421 & 0.0118 & 0.3052 & 0.0000 & 0.0000 & 0.0528 \\
\hline Mesic shrubland & 1,312 & 0.6250 & 1.1034 & 0.0000 & 0.0217 & 0.0006 & 0.1750 & 0.1179 & 0.1113 & 0.0176 & 0.1944 & 0.2367 \\
\hline Grassland & 2,849 & 0.1319 & 0.7616 & 0.0618 & 3.4173 & 0.8984 & 2.1602 & 0.3536 & 0.0866 & 0.4937 & 0.1804 & 0.8545 \\
\hline Barren & 3,280 & 0.0048 & 0.1711 & 0.0126 & 0.1195 & 0.1696 & 0.4892 & 0.0002 & 0.0740 & 0.0288 & 0.0046 & 0.1075 \\
\hline
\end{tabular}




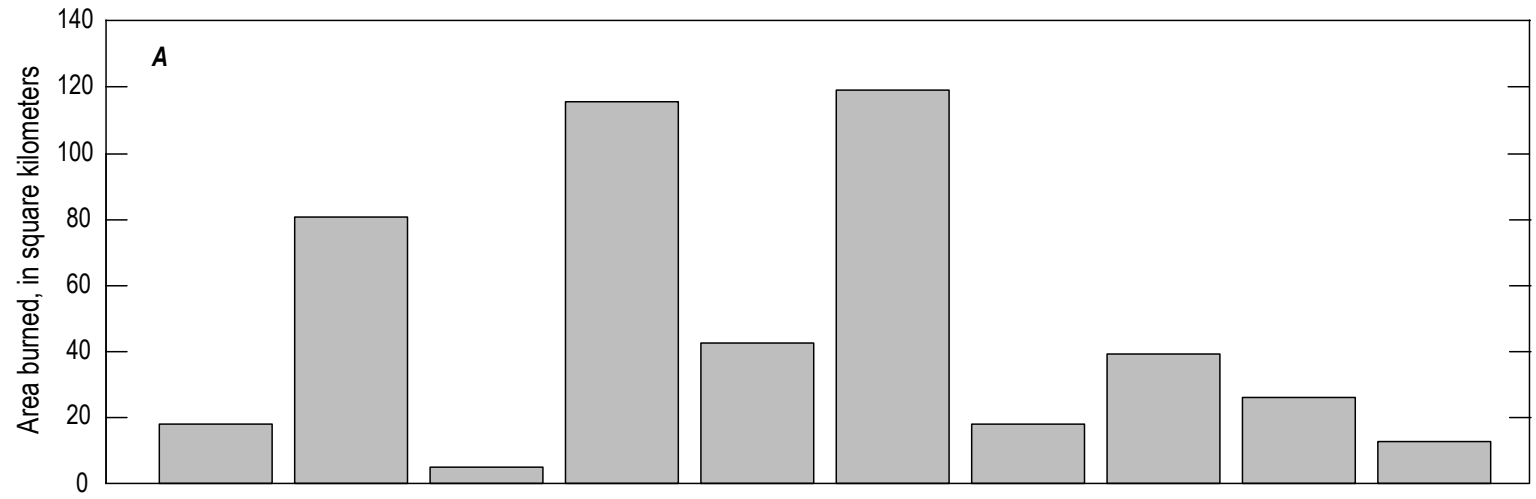

Figure 5.3. Plots of annual area bumed $(A)$ and wildland fire emissions $(B)$ from 2002 to 2011 across all of the main Hawaiian

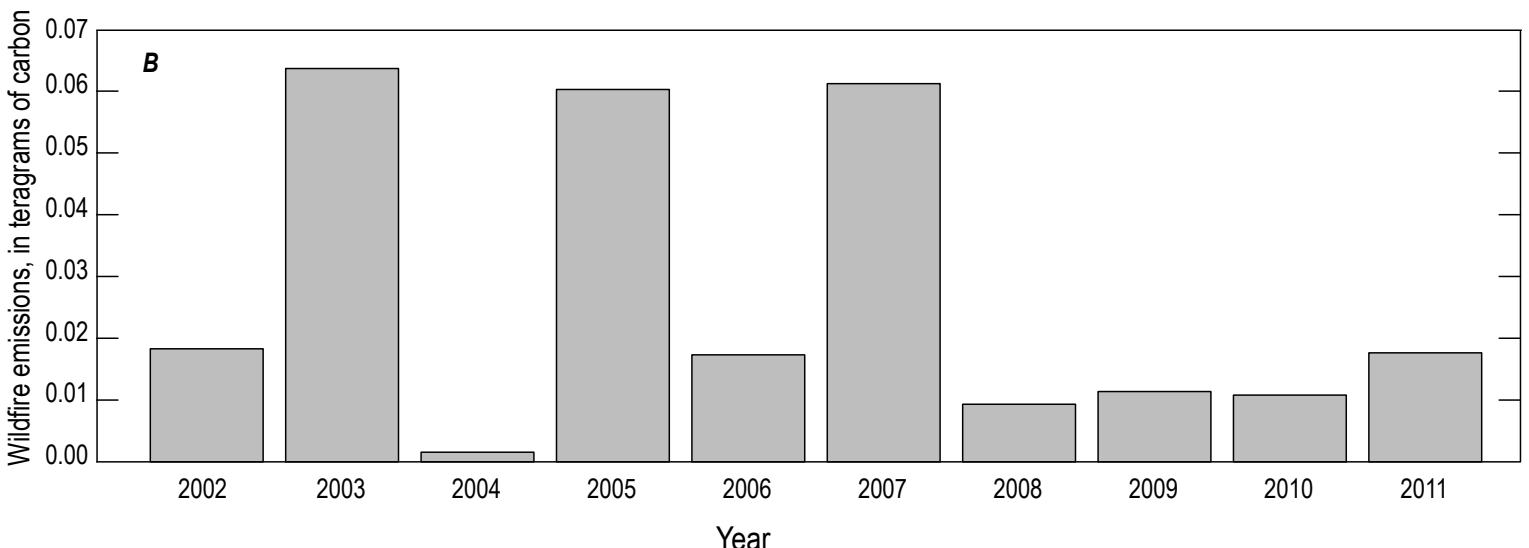
Islands, excluding Kaho'olawe, Lāna'i, and Ni'ihau.
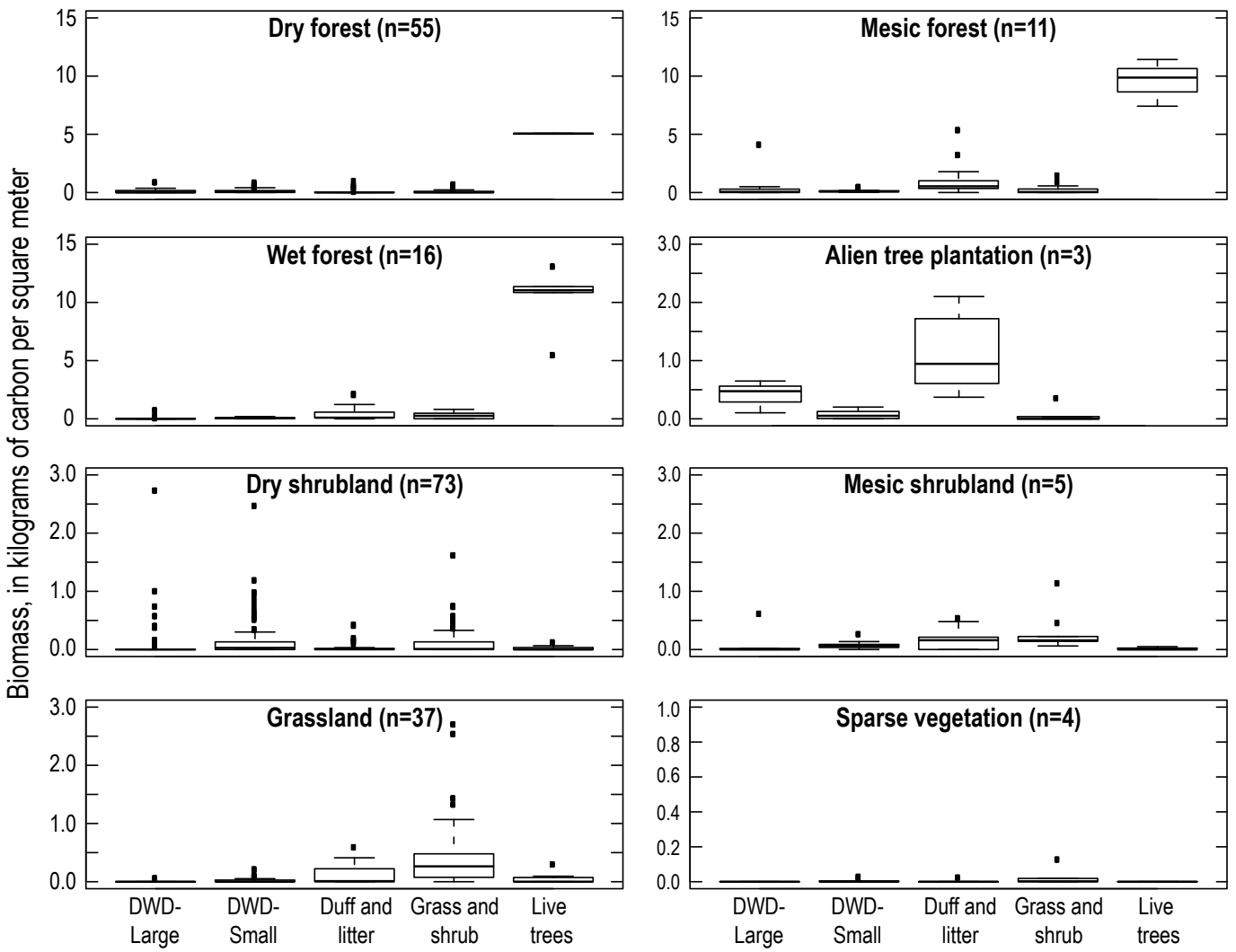

Figure 5.4. Boxplots showing the range of values for each biomass pool for the different vegetation classes of Hawai'i. The number of plots in the biomass database per vegetation class is shown in parentheses. DWD, downed woody debris. 
Table 5.5. Median biomass, surface area, total biomass, and percentage of total biomass by vegetation class.

$\left[\mathrm{kgC} / \mathrm{m}^{2}\right.$, kilograms of carbon per square meter; $\mathrm{TgC}$, teragrams of carbon]

\begin{tabular}{lcccc}
\hline \multicolumn{1}{c}{ Vegetation class } & $\begin{array}{c}\text { Biomass } \\
\left(\mathbf{k g C / \mathbf { m } ^ { 2 } )}\right.\end{array}$ & Area $\left(\mathbf{k m}^{2}\right)$ & $\begin{array}{c}\text { Total biomass } \\
(\mathrm{TgC})\end{array}$ & $\begin{array}{c}\text { Percent of } \\
\text { total biomass }\end{array}$ \\
\hline Dry forest & 5.22 & 1,061 & 5.9 & 8 \\
Mesic forest & 10.83 & 1,640 & 17.3 & 25 \\
Wet forest & 11.71 & 3,039 & 42.0 & 59 \\
Alien tree plantation & 1.50 & 243 & 0.4 & 1 \\
Dry shrubland & 0.04 & 1,505 & 0.6 & 1 \\
Mesic shrubland & 0.39 & 1,243 & 1.2 & 2 \\
Grassland & 0.28 & 2,790 & 3.2 & 4 \\
Sparse vegetation & 0.00 & 3,155 & 0.1 & 0 \\
\hline \multicolumn{1}{c}{ Total } & & 14,675 & 70.8 & 100 \\
\hline
\end{tabular}

Table 5.6. Median proportion of biomass consumed by vegetation class, moisture scenario, and biomass pool.

[Data produced by the First-Order Wildland Fire Effects Model (FOFEM). AGB-LT, Aboveground biomass-live trees; AGB-GS, Aboveground biomassshrub and grass; LDWD, Large downed woody debris; SDWD, Small downed woody debris]

\begin{tabular}{|c|c|c|c|c|c|c|}
\hline Vegetation class & Moisture scenario & AGB-LT & AGB-GS & LDWD & SDWD & Duff and litter \\
\hline \multirow{3}{*}{ Dry forest } & Very low & 0.35 & 1.00 & 0.19 & 0.70 & 0.71 \\
\hline & Low & 0.21 & 1.00 & 0.18 & 0.67 & 0.60 \\
\hline & Moderate & 0.07 & 1.00 & 0.16 & 0.65 & 0.45 \\
\hline \multirow[t]{3}{*}{ Mesic forest } & Very low & 0.35 & 0.96 & 0.44 & 1.00 & 1.00 \\
\hline & Low & 0.21 & 0.96 & 0.41 & 1.00 & 1.00 \\
\hline & Moderate & 0.07 & 0.96 & 0.37 & 1.00 & 1.00 \\
\hline \multirow[t]{3}{*}{ Wet forest } & Very low & 0.35 & 1.00 & 0.35 & 1.00 & 1.00 \\
\hline & Low & 0.21 & 1.00 & 0.33 & 1.00 & 1.00 \\
\hline & Moderate & 0.07 & 1.00 & 0.30 & 0.99 & 1.00 \\
\hline \multirow[t]{3}{*}{ Dry shrubland } & Very low & 0.34 & 1.00 & 0.21 & 0.43 & 0.72 \\
\hline & Low & 0.21 & 1.00 & 0.19 & 0.39 & 0.60 \\
\hline & Moderate & 0.06 & 1.00 & 0.18 & 0.36 & 0.45 \\
\hline \multirow[t]{3}{*}{ Alien tree plantation } & Very low & & 0.80 & 0.60 & 1.00 & 0.81 \\
\hline & Low & & 0.80 & 0.53 & 1.00 & 0.72 \\
\hline & Moderate & & 0.80 & 0.43 & 1.00 & 0.64 \\
\hline \multirow[t]{3}{*}{ Mesic shrubland } & Very low & 0.34 & 0.78 & 0.14 & 0.87 & 1.00 \\
\hline & Low & 0.21 & 0.78 & 0.13 & 0.85 & 1.00 \\
\hline & Moderate & 0.06 & 0.78 & 0.08 & 0.84 & 1.00 \\
\hline \multirow[t]{3}{*}{ Grassland } & Very low & 0.35 & 1.00 & 0.05 & 0.45 & 1.00 \\
\hline & Low & 0.21 & 1.00 & 0.04 & 0.42 & 1.00 \\
\hline & Moderate & 0.07 & 1.00 & 0.04 & 0.39 & 1.00 \\
\hline \multirow[t]{3}{*}{ Sparse vegetation } & Very low & & 0.92 & & 0.30 & 0.99 \\
\hline & Low & & 0.92 & & 0.26 & 0.99 \\
\hline & Moderate & & 0.92 & & 0.26 & 0.99 \\
\hline
\end{tabular}


Across vegetation classes the median percentage of biomass consumed in wildland fires was 21 percent of live tree, 93 percent of shrub and grass, 25 percent of large downed woody debris, 70 percent of small downed woody debris, and 86 percent of litter and duff (table 5.6). Simulated biomass consumption was greater for the very low moisture scenario (corresponding to high burn severity) and low for the moderate moisture scenario (corresponding to moderate burn severity). Wildland fire emissions from different vegetation types were largely dependent on the amount of pre-wildland fire biomass available for consumption (fig. 5.4; table 5.7). Wildland fire emissions, averaged across moisture scenarios, were greatest for mesic forests $\left(3.5 \mathrm{kgC} / \mathrm{m}^{2}\right.$ burned), followed by alien tree plantations $\left(2.3 \mathrm{kgC} / \mathrm{m}^{2}\right.$ burned), wet forests $\left(1.5 \mathrm{kgC} / \mathrm{m}^{2}\right.$ burned), and mesic shrublands ( $1.0 \mathrm{kgC} / \mathrm{m}^{2}$ burned) (table 5.7$)$.
Wildland fire emissions averaged $0.0271 \mathrm{TgC}(0.0942$ $\mathrm{TgCO}_{2}$-eq/yr) across Hawai'i (excluding Kaho'olawe, Lāna'i, and $\mathrm{Ni}^{\prime}$ ihau) between 2002 and 2011 (fig. 5.3B). The minimum and maximum annual values of carbon loss in wildland fire emissions were 2004 and 2003, respectively, and ranged from 0.0016 to $0.0637 \mathrm{TgC}\left(0.0055\right.$ to $0.2202 \mathrm{TgCO}_{2}$-eq). The greatest amount of total emissions resulted from wildland fires in the grassland vegetation class $\left(0.0142 \mathrm{TgC} / \mathrm{yr}\right.$ or $0.0479 \mathrm{TgCO}_{2}$-eq/yr on average; table 5.8), largely because of the extensive grassland area burned each year. However, wildland fires in other land-cover classes also resulted in substantial emissions because of their high biomass loads. For instance, average annual emissions were $0.0045 \mathrm{TgC}\left(0.0164 \mathrm{TgCO}_{2}\right.$-eq/yr) for mesic forests, $0.0032 \mathrm{TgC}$ $\left(0.0109 \mathrm{TgCO}_{2}\right.$-eq/yr) for mesic shrublands, and $0.0041 \mathrm{TgC}$ $\left(0.0079 \mathrm{TgCO}_{2}-\mathrm{eq} / \mathrm{yr}\right)$ for wet forests.

Table 5.7. Median carbon and $\mathrm{CO}_{2}$-equivalent emissions by vegetation class, moisture scenario, and biomass pool produced by the First-Order Wildland Fire Effects Model (FOFEM).

[C, carbon; $\mathrm{CO}_{2}$-eq, $\mathrm{CO}_{2}$-equivalent; $\mathrm{gC} / \mathrm{m}^{2}$, grams of carbon per square meter]

\begin{tabular}{|c|c|c|c|}
\hline Vegetation class & Moisture scenario & C emissions $\left(\mathrm{gC} / \mathrm{m}^{2}\right)$ & $\mathrm{CO}_{2}$-eq emissions $\left(\mathrm{gC} / \mathrm{m}^{2}\right)$ \\
\hline \multirow{3}{*}{ Dry forest } & Very low & 149 & 586 \\
\hline & Low & 144 & 566 \\
\hline & Moderate & 139 & 545 \\
\hline \multirow[t]{3}{*}{ Mesic forest } & Very low & 4,912 & 17,032 \\
\hline & Low & 3,349 & 11,690 \\
\hline & Moderate & 2,231 & 8,427 \\
\hline \multirow[t]{3}{*}{ Wet forest } & Very low & 1,616 & 5,456 \\
\hline & Low & 1,615 & 5,453 \\
\hline & Moderate & 1,285 & 4,333 \\
\hline \multirow[t]{3}{*}{ Alien tree plantation } & Very low & 2,554 & 10,337 \\
\hline & Low & 2,280 & 9,141 \\
\hline & Moderate & 1,993 & 7,887 \\
\hline \multirow[t]{3}{*}{ Dry shrubland } & Very low & 215 & 919 \\
\hline & Low & 212 & 856 \\
\hline & Moderate & 208 & 794 \\
\hline \multirow[t]{3}{*}{ Mesic shrubland } & Very low & 1,031 & 3,526 \\
\hline & Low & 1,029 & 3,518 \\
\hline & Moderate & 1,026 & 3,514 \\
\hline \multirow[t]{3}{*}{ Grassland } & Very low & 584 & 1,969 \\
\hline & Low & 584 & 1,969 \\
\hline & Moderate & 584 & 1,969 \\
\hline \multirow[t]{3}{*}{ Sparse vegetation } & Very low & 10 & 39 \\
\hline & Low & 9 & 37 \\
\hline & Moderate & 9 & 36 \\
\hline
\end{tabular}


Table 5.8. Wildland fire emissions by land-cover class from 2002 to 2011 across all islands, except Kaho'olawe, Lāna'i, and Ni'ihau.

\begin{tabular}{lccccccccccc}
\hline \multirow{1}{*}{ Vegetation class } & \multicolumn{1}{c}{ Annual wildfire emissions (TgC) } \\
\cline { 2 - 10 } & $\mathbf{2 0 0 2}$ & $\mathbf{2 0 0 3}$ & $\mathbf{2 0 0 4}$ & $\mathbf{2 0 0 5}$ & $\mathbf{2 0 0 6}$ & $\mathbf{2 0 0 7}$ & $\mathbf{2 0 0 8}$ & $\mathbf{2 0 0 9}$ & $\mathbf{2 0 1 0}$ & $\mathbf{2 0 1 1}$ \\
\hline Dry forest & 0.0001 & 0.0006 & 0.0001 & 0.0005 & 0.0002 & 0.0011 & 0.0008 & 0.0005 & 0.0002 & 0.0000 \\
Mesic forest & 0.0046 & 0.0151 & 0.0000 & 0.0002 & 0.0001 & 0.0159 & 0.0009 & 0.0004 & 0.0002 & 0.0079 \\
Wet forest & 0.0026 & 0.0166 & 0.0000 & 0.0000 & 0.0000 & 0.0000 & 0.0000 & 0.0000 & 0.0000 & 0.0041 \\
Alien tree plantation & 0.0000 & 0.0000 & 0.0000 & 0.0003 & 0.0000 & 0.0007 & 0.0001 & 0.0016 & 0.0000 & 0.0000 \\
Dry shrubland & 0.0004 & 0.0037 & 0.0004 & 0.0021 & 0.0021 & 0.0052 & 0.0001 & 0.0060 & 0.0019 & 0.0000 \\
Mesic shrubland & 0.0084 & 0.0149 & 0.0000 & 0.0003 & 0.0000 & 0.0024 & 0.0016 & 0.0015 & 0.0002 & 0.0026 \\
Grassland & 0.0022 & 0.0127 & 0.0010 & 0.0568 & 0.0149 & 0.0359 & 0.0059 & 0.0014 & 0.0082 & 0.0030 \\
Barren & 0.0000 & 0.0000 & 0.0000 & 0.0000 & 0.0000 & 0.0000 & 0.0000 & 0.0000 & 0.0000 & 0.0000 \\
\hline \multicolumn{1}{c}{ Total } & 0.0183 & 0.0637 & 0.0016 & 0.0603 & 0.0173 & 0.0612 & 0.0093 & 0.0114 & 0.0108 & 0.0176 \\
\hline
\end{tabular}

\subsection{Discussion}

Based on the estimates generated for this assessment, 0.29 percent of the total land area in Hawai' $i$ burned annually between 2002 and 2011. This percentage is slightly less than in the conterminous United States, where 0.39 percent of the total land area burned based on MTBS data for the same period (Eidenshink and others, 2007). This is lower than estimates using point-based agency records (Pierce and Pickett, 2014; Trauernicht and others, 2015) and likely reflects the fact that not all reported wildland fires were detected using remote sensing.

Average annual fossil-fuel emissions for Hawai' $\mathrm{i}$ (2002-2011) totaled 5.8 TgC (21.2 $\mathrm{TgCO}_{2}$-eq) (U.S. Energy Information Administration, 2014). Most fossil-fuel emissions were from the transportation sector ( 51.3 percent) and electrical power generation sector (38.5 percent). Industrial, commercial, and residential sectors contributed less to the fossil-fuel emissions ( 8.4 percent, 1.5 percent, and 0.3 percent, respectively). In turn, the annual estimate of wildland fire emissions generated for this assessment was $0.0271 \mathrm{TgC}$ $\left(0.0942 \mathrm{TgCO}_{2}\right.$-eq/yr), which amounts to only 0.5 percent of fossil-fuel emissions.

GPP of ecosystems in Hawai' $i$ averaged 2.23 TgC/yr from 2002 to 2010 (Selmants and others, this volume, chap. 6), and wildland fire emissions in Hawai' $i$ were equivalent to only 1.2 percent of GPP. Because this proportion is small, wildland fires did not substantially reduce the overall ability of Hawaiian ecosystems to sequester carbon for the baseline period of this assessment (2002-2011).

\subsubsection{Limitations and Uncertainties}

The analysis of burned area and wildland fire emissions for this chapter relied on newly developed data where burned area and severity were mapped from Landsat 7 imagery, guided by point locations for 135 known wildland fires. However, no visible burned area was observed in the Landsat 7 imagery for 48 of these wildland fires. The reported area burned for the missing wildland fires totaled $152 \mathrm{~km}^{2}$. When compared to the $480-\mathrm{km}^{2}$ total area burned of the mapped wildland fires, this suggests that the results presented here may only represent 76 percent of the total area affected by wildland fires. Other uncertainties were introduced in this analysis because small wildland fires $\left(<0.4 \mathrm{~km}^{2}\right.$ burned) were not included, although they typically contribute little to the total area burned (Strauss and others, 1989; Stocks and others, 2002) and, consequently, emissions.

Another source of uncertainty in this analysis of wildland fire emissions for Hawai' $i$ is the pre-fire biomass data collected for this assessment. Prior to the assessment, the only spatially complete data source representing biomass in all Hawaiian ecosystems was the LANDFIRE data layers (Rollins, 2009), and the general feeling among the scientific and management community in Hawai' $i$ was that these data did not adequately represent fine-scale biomass values or spatial variability in biomass across ecosystem types in the state. Therefore, a database was compiled of biomass measurements from a variety of published and unpublished studies for this assessment. This effort highlighted a general lack of field-based measurements available to fully represent biomass values across the diverse climate and topographic gradients and land-use histories in Hawai' ${ }^{\prime}$. Light detection and ranging (lidar) data were used to generate aboveground biomass estimates for this assessment, but lack detailed information about other biomass components such as downed woody debris and litter (Selmants and others, this volume, chap. 6). However, estimates of the amount of biomass for non-forest ecosystems (shrublands and grasslands) remain low. Future efforts to understand carbon and wildland fire dynamics in Hawai'i would benefit from a large-scale systematic sampling effort to quantify biomass in shrublands and grasslands across moisture and productivity gradients and in relation to the presence of nonnative species.

Wildland fire is widely used for sugar cane agriculture in Hawai' $i$ to remove biomass before harvest. Agricultural wildland fires were not included in this assessment because complete data characterizing their occurrence are lacking. However, based on previous studies in Brazil, sugar cane biomass can vary between 5 and $15 \mathrm{~kg} / \mathrm{m}^{2}$ and burning removes approximately 20 percent of 
that biomass in the form of cane tops, leaves, and straw that are not used for sugar or energy production (Ripoli and others, 2000). Sugar cane is typically harvested on a 3-year rotation in Hawai' $i$, and approximately $65.0 \mathrm{~km}^{2} / \mathrm{yr}$ of sugar cane was harvested in Hawai'i on average from 2012 to 2014 (National Agricultural Statistics Service, 2015). Assuming that sugar cane biomass was between 5 and $15 \mathrm{~kg} / \mathrm{m}^{2}$, a 50 percent carbon content, that 20 percent of cane biomass is lost to burning, and that all the sugar cane area was burned, emissions from sugar cane burning would range between 0.03 and $0.10 \mathrm{TgC} / \mathrm{yr}$. This is 20 percent less to 260 percent more than the average annual emissions for wildland fires and, as such, represents a potentially important component of wildland fire emissions that were not considered in this study.

Active volcanoes can also be a potential source of $\mathrm{CO}_{2}, \mathrm{SO}_{2}$, and other greenhouse gasses. Globally, $\mathrm{CO}_{2}$ and $\mathrm{SO}_{2}$ emissions from volcanoes are equivalent to about 0.22 percent of anthropogenic emissions (Williams and others, 1992), but volcanoes may be a substantial emissions source at local to regional scales. Volcanic emissions were also not included in this assessment because they do not represent a flux from ecosystems. However, active volcanoes in Hawai $i$ are a source of wildland fire ignitions and they offer an interesting comparison with other types of fires. Gerlach and others (2002) estimated emissions from Kilauea Volcano to be $8,500 \mathrm{Mg}$ of $\mathrm{CO}_{2}$ /day from 1995 to 1998 . On an annual timestep, this daily rate is equivalent to $3.1025 \mathrm{TgCO}_{2} / \mathrm{yr}$, or 3,300 percent greater than the mean rate of wildland fire emissions $\left(0.0942 \mathrm{TgCO}_{2}-\mathrm{eq} / \mathrm{yr}\right)$ and 38 percent greater than the GPP $\left(8.2 \mathrm{TgCO}_{2}\right.$-eq/yr) estimated for this assessment.

\subsubsection{Mitigating Negative Impacts of Wildland Fires on Carbon Cycling Through Aggressive Fire and Vegetation Management}

Based on the summaries of the results generated for the wildland fire portion of this assessment, the immediate impacts of wildland fire on carbon cycling from wildland fire emissions is small in Hawai' $i$, particularly compared to fossil-fuel emissions. However, the long-term effects of wildland fire in Hawai' $i$ should be considered when assessing the regional role of wildland fires in carbon storage, because the importance of fire in Hawai' $i$ is somewhat unique from its importance in the conterminous United States. In particular, vegetation type can convert from woodydominated ecosystems to nonnative grassland after wildland fire in forest and shrubland ecosystems in Hawai $i$, resulting in a potentially large loss of carbon-storage and carbon-sequestration capacity. For example, Litton and others (2006) found that transformation of native Hawaiian dry forest to nonnative grasslands reduced aboveground carbon storage in live biomass by a factor of 14 , with native dry forest ecosystems storing $5.12 \mathrm{kgC} / \mathrm{m}^{2}$ and converted grasslands dominated by $C$. setaceus containing only $0.37 \mathrm{kgC} / \mathrm{m}^{2}$.

On a landscape level, Ellsworth and others (2014) examined the rate of land-type conversion from both wildland fire occurrence and wildland fire suppression during the period from 1950 to 2010 for two military bases on the island of $\mathrm{O}^{`}$ ahu that vary in wildland fire prevention capacity:
Schofield Barracks (297 m above sea level [ASL]; mean annual precipitation [MAP], 1,000 mm; mean annual temperature [MAT], $22^{\circ} \mathrm{C}$ ) and Makua Military Reservation (108 m ASL; MAP, $864 \mathrm{~mm}$; MAT, $23{ }^{\circ} \mathrm{C}$ ). Schofield instituted improved, onsite wildland fire management in the 1990s, whereas at Makua the remoteness of the site coupled with common anthropogenic ignitions on and just outside of the base have complicated wildland fire suppression efforts. Both bases are divided into core active-training areas with abundant ignition sources and outside buffer areas with fewer ignitions. Over the 50-60-year period of the Ellsworth and others (2014) study, there were marked differences in land-cover change associated with wildland fire activity at the two bases, related to both ignition sources and wildland fire prevention activities. At Schofield, in the core area of active training (which has abundant ignition sources), recurring wildland fires expanded grassland cover from 48 to 63 percent over 61 years, with concurrent reductions in woody cover (fig. 5.5A). Outside of the wildland fire break, active wildland fire mitigation (in other words, having a wildland fire crew onsite) resulted in the opposite pattern where woody cover expanded from 79 to 98 percent during the same period (fig. $5.5 B$ ). In Makua, however, where wildland fire suppression is more challenging, there was

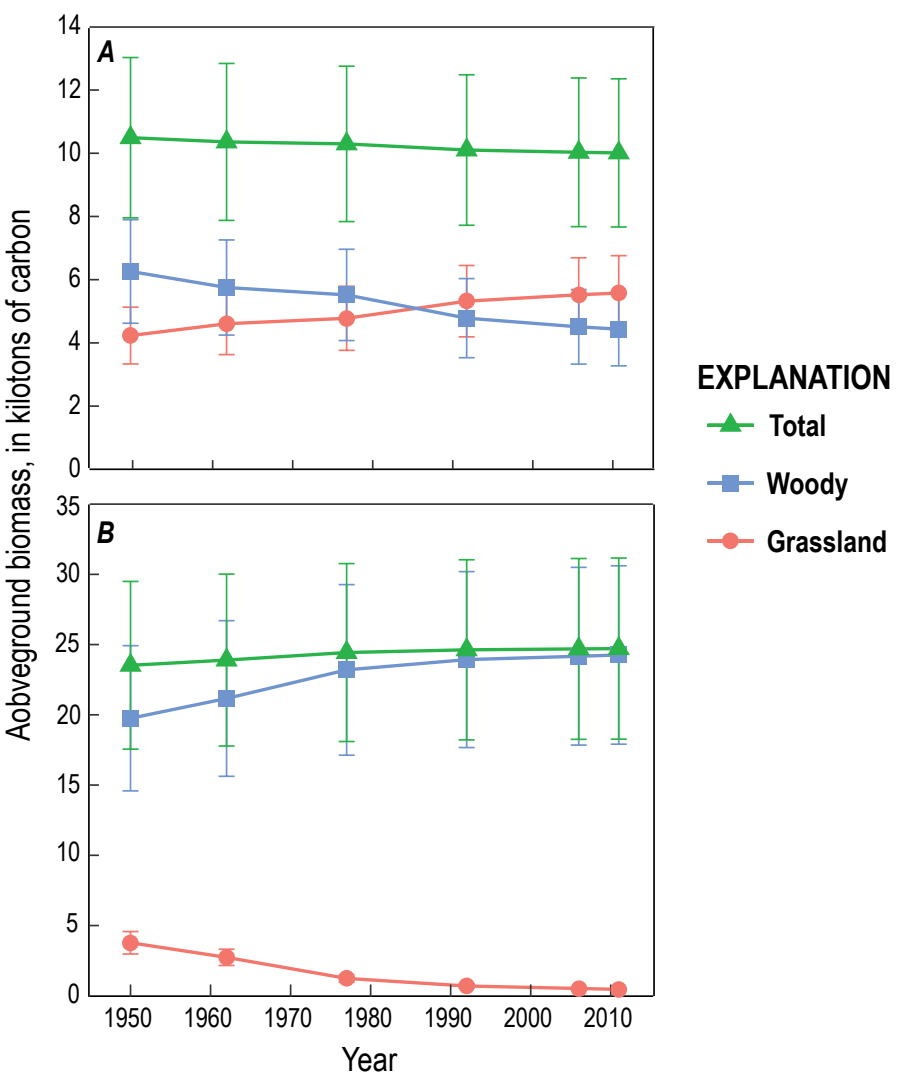

Figure 5.5. Plots of aboveground carbon partitioned into grassland and woody vegetation contained in the active wildland-fire training area at Schofield Barracks, O'ahu, Hawai'i ( $A$ ), an area subject to frequent wildland fires, and in the watershed area outside of the training area $(B)$, where wildland fire breaks and suppression have limited wildland fire incursion. Mean values are shown with \pm 1 standard deviation error bars. 
a reduction in woody cover and expansion of grassland cover over 49 years in both the area of active training (from 13 to 66 percent grassland expansion) and outside of the wildland fire break (from 30 to 41 percent grassland expansion). Conversion of forest to grassland alters fuel heights and increases modeled surface wildland fire spread and intensity, which represents not only forest loss but also a positive feedback to grassland dominance. Importantly, these conversions of woody-dominated vegetation to grasslands from wildland fire represent a loss in aboveground carbon storage of 26-41 percent (Ellsworth and others, 2014).

The results of the studies highlighted above demonstrate large-type conversions from forest to grassland where wildland fires have occurred during the past 50 or more years which represents a loss of carbon-storage and carbonsequestration potential. On a smaller scale, they demonstrate a corresponding conversion from grassland back to forest in areas of active wildland fire suppression, which represents carbon sequestration and increased carbon storage. The results generated for this assessment suggest that an average of $62 \mathrm{~km}^{2}$ of forest and $136 \mathrm{~km}^{2}$ of shrubland burn each year in Hawai' $i$. Without active restoration efforts, based on the results highlighted above, much of that area will convert to and persist as nonnative grassland ecosystems. If wildland fires and vegetation-type conversions in Hawai' $i$ continue in the future at current or increased rates, the potential for carbon sequestration in woody-dominated ecosystems in Hawai ${ }^{\circ} i$ will be greatly reduced. However, these results also suggest that more active wildland fire management in the form of onsite wildland fire suppression can be an effective approach to controlling wildland fires, even allowing for type conversions back to woody ecosystems. Onsite wildland fire management will not always be feasible, however, and there is an urgent need to explore other options for limiting wildland fire spread, such as the use of greenbreaks and domestic livestock grazing in areas with little or no native species component (Evans and others, 2015).

The risks and impacts of wildland fire can be reduced through prevention, pre-wildland fire preparedness and vegetation management, increased wildland fire suppression capacity, and enhanced post-wildland fire response. Given that nearly all wildland fires in Hawai' $i$ are human-caused, public outreach and education are critical. Local organizations, including the Hawai' $i$ Division of Forestry and Wildlife and the Hawai' $i$ Wildlfire Management Organization are working to adapt national resources such as Ready, Set, Go! and Firewise Communities to local contexts (Hawai'i Wildfire Management Organization, 2015). Wildland fire managers in Hawai' $i$ point to landowner preparedness and resource mapping (for example, access, water, and valued resources) as key components of presuppression planning (Clay Trauernicht, University of Hawai` $\mathrm{i}$ at Mānoa, unpublished data).
Pre-wildland fire management also includes reducing wildland fire risk directly by reducing the quantity and continuity of available fuels. Fuels reduction has been shown to reduce costs and increase effectiveness of wildland fire suppression elsewhere (Hurteau and North, 2009; Syphard and others, 2011), but "traditional" mechanical and chemical means of fuels reduction are costly to implement in Hawai ${ }^{i} i$, owing to tropical, year-long growing seasons and difficult terrain. Managed grazing has been shown to effectively reduce fine fuel loads through field assessments (Blackmore and Vitousek, 2000; Evans and others, 2015), experimental prescriptive trials (Castillo and others, 2003; Warren and others, 2007; Ansari and others, 2008), and remote sensing (Elmore and others, 2005). Land managers are also experimenting with vegetated fuel breaks, or 'greenstrips,' that integrate wildland fire-resistant shrubs and grasses and (or) use trees to reduce herbaceous fuels by shading (Trauernicht and others, 2012). However, plant-species suitability and the effectiveness of greenstrip implementation in Hawai' $i$ is only beginning to be quantified (Ellsworth, 2012; Ellsworth and others, 2015).

Wildland fire suppression in Hawai' $i$ is challenging owing to completely novel fuels, high spatial and temporal environmental variability, and complex, challenging terrain. For example, because of limited access and dangerous conditions, suppression efforts heavily rely on helicopter support, which substantially increases suppression costs. Hawai'i's geography also prevents the rapid mobilization of heavy equipment like water trucks, brush trucks, and dozers among islands, although personnel are typically mobilized in the event of large wildland fires. Under these constraints, County, State and Federal wildland fire response agencies in the state cooperate frequently on wildland fire incidents and local incident commanders stress the importance of both personal relationships and mutual-aid agreements. The top recommendations from Incident Commanders in Hawai' $i$ for improving suppression efforts include increased training, personnel, and equipment as well as the extent of pre-wildland fire mitigation efforts (Clay Trauernicht, University of Hawai' ${ }^{\circ}$ at Mānoa, unpublished data).

Wildland fire impacts, such as the conversion of forest to grassland, can also be mitigated by increasing resources for, and effectiveness of, post-wildland fire assessment and response in Hawai' $i$. Rapid response measures, such as soil stabilization and weed management, and longer term revegetation and restoration are currently limited by funding and the availability of materials, especially native seeds. Woody plant recovery in burned areas is typically by nonnative species and, therefore, establishing and maintaining native diversity will require more intensive management and landscape-scale approaches to reforestation and restoration (Loh and others, 2009; Friday and others, 2015). 


\subsection{References Cited}

Albini, F.A., Brown, J.K., Reinhardt, E.D., and Ottmar, R.D., 1995, Calibration of a large fuel burnout model: International Journal of Wildland Fire, v. 5, no. 3, p. 173-192, available at http://dx.doi.org/10.1071/WF9950173.

Albini, F.A., and Reinhardt, E.D., 1995, Model ignition and burning rate of large woody natural fuels: International Journal of Wildland Fire, v. 5, no. 2, p. 81-91, available at http://dx.doi.org/10.1071/WF9950081.

Albini, F.A., and Reinhardt, E.D., 1997, Improved calibration of a large fuel burnout model: International Journal of Wildland Fire, v. 7, no. 1, p. 21-28, available at http://dx.doi. org/10.1071/WF9970021.

Ansari, S., Hirsh, H., and Thair, T., 2008, Removal of invasive fire-prone grasses to increase training lands in the Pacific: Department of Defense Legacy Project 07-362, available at http://www.dtic.mil/dtic/tr/fulltext/u2/a534619.pdf.

Aplet, G.H., and Vitousek, P.M., 1994, An age-altitude matrix analysis of Hawaiian rain-forest succession: Journal of Ecology, v. 82, no. 1, p. 137-147.

Asner, G.P., Hughes, R.F., Varga, T.A., Knapp, D.E., and Kennedy-Bowdoin, T., 2009, Environmental and biotic controls over aboveground biomass throughout a tropical rain forest: Ecosystems, v. 12, no. 2, p. 261-278, available at http://dx.doi.org/10.1007/s10021-008-9221-5.

Bachelet, D., Neilson, R.P., Lenihan, J.M., and Drapek, R.J., 2001, Climate change effects on vegetation distribution and carbon budget in the United States: Ecosystems, v. 4, no. 3, p. $164-185$.

Blackmore, M., and Vitousek, P.M., 2000, Cattle grazing, forest loss, and fuel loading in a dry forest ecosystem at $\mathrm{Pu} u$ Wa'aWa'a Ranch, Hawai'i: Biotropica, v. 32, no. 4a, p. 625-632.

Bonan, G.B., 2008, Forests and climate change-forcings, feedbacks, and the climate benefits of forests: Science, v. 320, p. 1444-1449.

Castillo, J.M., Enriques, G., Nakahara, M., Weise, D., Ford, L., Moraga, R., and Vihnanek, R., 2007, Effects of cattle grazing, glyphosphate, and prescribed burning on fountain grass fuel loading in Hawai 'i, in Masters, R.E., and Galley, K.E.M., eds., Proceedings of the 23rd Tall Timbers Fire Ecology Conference - Fire in Grassland and Shrubland Ecosystems: Tallahassee, Fla., Tall Timbers Research Station, p. 230-239. [Also available at http://talltimbers.org/tall-timbers-fireecology-conference-proceedings-volume-23/.]
Chapin, F.S., III, Woodwell, G.M., Randerson, J.T., Rastetter, E.B., Lovett, G.M., Baldocchi, D.D., Clark, D.A., Harmon, M.E., Schimel, D.S., Valentini, R., Wirth, C., Aber, J.D., Cole, J.J., Goulden, M.L., Harden, J.W., Heimann, M., Howarth, R.W., Matson, P.A., McGuire, A.D., Melillo, J.M., Mooney, H.A., Neff, J.C., Houghton, R.A., Pace, M.L., Ryan, M.G., Running, S.W., Sala, O.E., Schlesinger, W.H., and Schulze, E.D., 2006, Reconciling carbon-cycle concepts, terminology, and methods: Ecosystems, v. 9, no. 7, p. 1041-1050.

Chu, P., Yan, W., and Fujioka, F., 2002, Fire-climate relationships and long-lead wildfire predictions for Hawaii: International Journal of Wildland Fire, v. 11, no. 1, p. 25-31.

Cleary, M.B., Pendall, E., and Ewers, B.E., 2010, Aboveground and belowground carbon pools after fire in mountain big sagebrush steppe: Rangeland Ecology \& Management, v. 63, no. 2, p. 187196, available at http://dx.doi.org/10.2111/REM-D-09-00117.1.

Cole, R.J., and Litton, C.M., 2014, Vegetation response to removal of non-native feral pigs from Hawaiian tropical montane wet forest: Biological Invasions, v. 16, no. 1, p. 125-140, available at http://dx.doi.org/doi:10.1007/s10530-013-0508-x.

Cuddihy, L.W., and Stone, C.P., 1990, Alteration of native Hawaiian vegetation-Effects of humans, their activities and introductions: Honolulu, University of Hawai'i Press, 138 p.

D‘Antonio, C.M., and Vitousek, P.M., 1992, Biological invasions by exotic grasses, the grass/fire cycle, and global change: Annual Review of Ecology and Systematics, v. 23, p. 63-87.

Dolling, K., Chu, P., and Fujioka, F., 2005, A climatological study of the Keetch/Byram drought index and fire activity in the Hawaiian Islands: Agricultural and Forest Meteorology, v. 133, no. 1-4, p. $17-27$.

Eidenshink, J., Schwind, B., Brewer, K., Zhu, Z.-L., Quayle, B., and Howard, S., 2007, A project for monitoring trends in burn severity: Fire Ecology, v. 3, no. 1, p. 3-21.

Ellsworth, L.M., 2012, Improved wildfire management in Megathyrsus maximus dominated ecosystems in Hawai' $\mathrm{i}$ : Honolulu, University of Hawai'i at Mānoa, Ph.D. Dissertation, $126 \mathrm{p}$.

Ellsworth, L.M., Litton, C.M., Dale, A.P., Miura, T., 2014, Invasive grasses change landscape structure and fire behaviour in Hawaii: Applied Vegetation Science, v. 17, no. 4, p. 680-689, available at http://dx.doi.org/10.1111/avsc.12110.

Ellsworth, L.M., Litton, C.M., and Leary, J.J.K., 2015, Restoration impacts on fuels and fire potential in a dryland tropical ecosystem dominated by the invasive grass Megathyrsus maximus: Restoration Ecology, v. 23, no.6, p. 955-963, available at http:// dx.doi.org/10.1111/rec.12263. 
Elmore, A.J., Asner, G.P., and Hughes, R.F., 2005, Satellite monitoring of vegetation phenology and fire fuel conditions in Hawaiian drylands: Earth Interactions, v. 9, no. 21, 21 p., avaialable at http://dx.doi.org/10.1175/EI160.1.

Evans, E.W., Ellsworth, L.M., and Litton, C.M., 2015, Impact of grazing on fine fuels and potential wildfire behaviour in a non-native tropical grassland: Pacific Conservation Biology, v. 21, no. 2, p. 126-132, available at http://dx.doi. org/10.1071/PC14910.

Friday, J.B., Cordell, S., Giardina, C.P., Inman-Narahari, F., Koch, N., Leary, J.J.K., Litton, C.M., and Trauernicht, C., 2015, Future directions for forest restoration in Hawai' $i$ : New Forests, v. 46, no. 5, p. 1-14, available at http://dx.doi. org/10.1007/s11056-015-9507-3.

Gerlach, T.M., McGee, K.A., Elias, T., Sutton, A.J., and Doukas, M.P., 2002, Carbon dioxide emission rate of Kīlauea Volcano-Implications for primary magma and the summit reservoir: Journal of Geophysical ResearchSolid Earth, v. 107, no. B9, 15 p., available at http://dx.doi. org/10.1029/2001JB000407.

Giambelluca, T.W., Chen, Q., Frazier, A.G., Price, J.P., Chen, Y.-L., Chu, P.-S., Eischeid, J.K., and Delparte, D.M., 2013, Online Rainfall Atlas of Hawai' $i$ : Bulletin of the American Meteorological Society, v. 94, p. 313-316. (Available at http://rainfall.geography.hawaii.edu.)

Hawai'i Wildfire Management Organization, 2013, Hawaii State wildfire history dataset: University of Hawai' $i$, College of Tropical Agriculture and Human Resources web page, available at http://gis.ctahr.hawaii.edu/WildfireHistory.

Hawai'i Wildfire Management Organization, 2015, Ready, Set, Go! Your personal wildland fire action guide: Kamuela, Hawai' $i$, Hawai'i Wildfire Management Organization, 20 p. [Also available at http://www.hawaiiwildfire.org/s/RSGHawaii-Your-Personal-Wildland-Fire-Action-Guide.pdf.]

Hughes, R.F., Vitousek, P.M., and Tunison, J., 1991, Alien grass invasion and fire in the seasonal submontane zone of Hawai' $i$. Ecology, v. 72, no. 2, p. 743-746.

Hurteau, M.D., and Brooks, M.L., 2011, Short- and long-term effects of fire on carbon in US dry temperate forest systems: Bioscience, v. 61, no. 2, p. 139-146, available at http:// dx.doi.org/10.1525/bio.2011.61.2.9.

Hurteau, M., and North, M., 2009, Fuel treatment effects on tree-based forest carbon storage and emissions under modeled wildfire scenarios: Frontiers in Ecology and the Environment, v. 7, no. 8, p. 409-414, http://dx.doi. org/10.1890/080049.
Intergovernmental Panel on Climate Change, 2007, Climate change 2007-The physical science basis, in Solomon, S., Qin, D., Manning, M., Marquis, M., Averyt, K., Tignor, M.M.B., Miller, H.L., Jr., and Chen, Z., eds., Contribution of Working Group I to the Fourth Assessment Report of the Intergovernmental Panel on Climate Change: Cambridge, England, and New York, Cambridge University Press, 996 p., available at http://www.ipcc.ch/report/ar4/wg1/.

Kashian, D.M., Romme, W.H., Tinker, D.B., Turner, M.G., and Ryan, M.G., 2013, Postfire changes in forest carbon storage over a 300-year chronosequence of Pinus contortadominated forests: Ecological Monographs, v. 83, no. 1, p. 49-66, available at http://dx.doi.org/10.1890/11-1454.1.

Keith, H., Mackey, B.G., and Lindenmayer, D.B., 2009, Re-evaluation of forest biomass carbon stocks and lessons from the world's most carbon-dense forests: Proceedings of the National Academy of Sciences, v. 106, no. 28, p. 11635-11640.

Lieth, H., 1973, Primary production-Terrestrial ecosystems: Human Ecology, v. 1, no. 4, p. 303-332.

Litton, C.M., and Kauffman, J.B., 2008, Allometric models for predicting aboveground biomass in two widespread woody plants in Hawai'i: Biotropica, v. 40, no. 3, p. 313-320.

Litton, C.M., Sandquist, D.R., and Cordell, S., 2006, Effects of non-native grass invasion on aboveground carbon pools and tree population structure in a tropical dry forest of Hawaii: Forest Ecology and Management, v. 231, no. 1-3, p. 105-113, available at http://dx.doi.org/10.1016/j. foreco.2006.05.008.

Loh, R., Ainsworth, A., Tunison, T., and D'Antonio, C., 2009, Testing native species response to fire - a first step towards building fire resilient plan communities at Hawai' $\mathrm{i}$ Volcanoes National Park: Honolulu, University of Hawai' $i$ at Mānoa, Pacific Cooperative Studies Unit Technical Report 167, 30 p., available at http://manoa.hawaii.edu/ hpicesu/techr/167/default.htm.

National Agricultural Statistics Service, 2015, Crop Production 2014 Summary: U.S. Department of Agriculture, 99 p. [Available at http://usda.mannlib.cornell.edu/usda/ current/CropProdSu/CropProdSu-01-12-2015_revision.pdf.]

Pan, Y., Birdsey, R.A., Fang, J., Houghton, R., Kauppi, P.E., Kurz, W.A., Phillips, O.L., Shvidenko, A., Lewis, S.L., Canadell, J.G., Ciais, P., Jackson, R.B., Pacala, S.W., McGuire, A.D., Piao, S., Rautiainen, A., Sitch, S., and Hayes, D., 2011, A large and persistent carbon sink in the World's forests: Science, v. 333, p. 988-993, available at https://doi.org/10.1126/science.1201609. 
Pierce, A.D., and Pickett, E., 2014, Building a spatial database of fire occurrence in Hawai' $i$ : Fire Management Today, v. 74, no. 1, p. 37-42, available at https:/www.fs.fed.us/ sites/default/files/fire-management-today/74-1.pdf.

Price, J.P., Jacobi, J.D., Gon, S.M., III, Matsuwaki, D., Mehrhoff, L., Wagner, W., Lucas, M., and Rowe, B., 2012, Mapping plant species ranges in the Hawaiian IslandsDeveloping a methodology and associated GIS layers: U.S. Geological Survey Open-File Report 2012-1192, 34 p., 1 appendix (species table), 1,158 maps, available at http:// pubs.usgs.gov/of/2012/1192/.

Raich, J.W., Russell, A.E., and Vitousek, P.M., 1997, Primary productivity and ecosystem development along an elevational gradient on Mauna Loa, Hawai‘i: Ecology, v. 78, no. 3, p. 707-721.

Reinhardt, E.D., Keane, R.E., and Brown, J.K., 1997, First Order Fire Effects Model-FOFEM 4.0, User's Guide: U.S. Department of Agriculture, Forest Service General Technical Report INT-GTR-344, 61 p.

Ripoli, T.C.C., Molina, W.F., Jr., and Ripoli, M.L.C., 2000, Energy potential of sugar cane biomass in Brazil: Scientia Agricola, v. 57, no. 4, p. 677-681.

Rollins, M.G., 2009, LANDFIRE: A nationally consistent vegetation, wildland fire, and fuel assessment: International Journal of Wildland Fire, v. 18, p. 235-249.

Saugier, B., Roy, J., and Mooney, H.A., 2001, Estimations of global terrestrial productivity: converging toward a single number?, chap. 23 of Roy, J., Saugier, R., and Mooney, H.A., eds., Terrestrial Global Productivity: San Diego, Calif., Academic Press, 573 p.

Schuur, E.A.G., Chadwick, O.A., and Matson, P.A., 2001, Carbon cycling and soil carbon storage in mesic to wet Hawaiian montane forests: Ecology, v. 82, no. 11, p. 3182-3196.

Seiler, W., and Crutzen, P.J., 1980, Estimates of gross and net fluxes of carbon between the biosphere and the atmosphere from biomass burning: Climatic Change, v. 2, no. 3, p. $207-247$.

Shiels, A.B., and Drake, D.R., 2011, Are introduced rats (Rattus rattus) both seed predators and dispersers in Hawai'i?: Biological Invasions, v. 13, no. 4, p. 883-894, available at http://dx.doi.org/10.1007/s10530-010-9876-7.

Short, K.C., 2014, A spatial database of wildfires in the United States, 1992-2011: Earth System Science Data, v. 6, no. 1, 27 p., available at http://dx.doi.org/10.5194/essd-6-1-2014.
Stocks, B.J., Mason, J.A., Todd, J.B., Bosch, E.M., Wotton, B.M., Amiro, B.D., Flannigan, M.D., Hirsch, K.G., Logan, K.A., Martell, D.L., and Skinner, W.R., 2002, Large forest fires in Canada, 1959-1997: Journal of Geophysical ResearchAtmospheres, v. 108, no. D1, 12 p.

Strauss, D., Bednar, L., and Mees, R., 1989, Do one percent of forest fires cause ninety-nine percent of the damage?: Forest Science, v. 35, no. 2, p. 319-328.

Syphard, A.D., Scheller, R.M., Ward, B.C., Spencer, W.D., and Strittholt, J.R., 2011, Simulating landscape-scale effects of fuels treatments in the Sierra Nevada, California, USA: International Journal of Wildland Fire, v. 20, no. 3, p. 364-383, available at http://dx.doi.org/10.1071/WF09125.

Trauernicht, C., Murphy, B.P., Portner, T.E., and Bowman, D.M.J.S., 2012, Tree cover-fire interactions promote the persistence of a fire-sensitive conifer in a highly flammable savanna: Journal of Ecology, v. 100, no. 4, p. 958-968, available at http://dx.doi. org/10.1111/j.1365-2745.2012.01970.x.

Trauernicht, C., Pickett, E., Giardina, C.P., Litton, C.M., Cordell, S., and Beavers, A., 2015, The contemporary scale and context of wildfire in Hawai'i: Pacific Science, v. 69, no. 4, p. 427-444, available at http://dx.doi.org/10.2984/69.4.1.

Turner, M.G., Baker, W.L., Peterson, C.J., and Peet, R.K., 1998, Factors influencing succession-Lessons from large, infrequent natural disturbances: Ecosystems, v. 1, no. 6, p. 511-523.

U.S. Energy Information Administration, 2014, Energy-related carbon dioxide emissions at the State level, 2000-2011: Washington, D.C., U.S. Department of Energy, 16 p.

Vitousek, P., Asner, G.P., Chadwick, O.A., and Hotchkiss, S., 2009, Landscape-level variation in forest structure and biogeochemistry across a substrate age gradient in Hawaii: Ecology, v. 90, no. 11, p. 3074-3086.

Warren, S.D., Sherman, S.A., and Zeidler, J.A., 2007, Assessment of livestock grazing on fuels and cultural resources at Makua Military Reservation (MMR), Island of Oahu, Hawaii: Fort Collins, Colo., Colorado State University, Center for the Environmental Management of Military Lands TPS07-06.

Whittaker, R.H., and Likens, G.E., 1973, Primary production-The biosphere and man: Human Ecology, v. 1, no. 4, p. 357-369.

Williams, S.N., Schaefer, S.J., Calvache, V.M.L., and Lopez, D., 1992, Global carbon dioxide emission to the atmosphere by volcanos: Geochimica Et Cosmochimica Acta, v. 56, no. 4, p. 1765-1770.

Ziegler, A.C., 2002, Hawaiian Natural History, Ecology, and Evolution: Honolulu, University of Hawaii Press, 477 p. 



\title{
Chapter 6. Baseline Carbon Storage and Carbon Fluxes in Terrestrial Ecosystems of Hawai'i
}

\author{
By Paul C. Selmants, ${ }^{1}$ Christian P. Giardina, ${ }^{2}$ Sinan Sousan, ${ }^{3}$ David E. Knapp, ${ }^{3}$ Heather L. Kimball, ${ }^{4}$ Todd J. Hawbaker, ${ }^{1}$ \\ Alvaro Moreno, ${ }^{5}$ Jami Seirer, ${ }^{5}$ Steve W. Running, ${ }^{5}$ Tomoaki Miura, ${ }^{6}$ Rafael Bergstrom, ${ }^{6}$ R. Flint Hughes, ${ }^{2}$ Creighton M. \\ Litton, ${ }^{6}$ and Gregory P. Asner ${ }^{3}$
}

\subsection{Highlights}

- Carbon storage and fluxes were examined for terrestrial ecosystems on the seven main Hawaiian Islands: Hawai'i, Maui, Moloka'i, Lāna'i, Kaho'olawe, O'ahu, and Kaua' $i$. Total carbon stored in terrestrial ecosystems across these islands was estimated to be $258 \mathrm{TgC}$, of which 71 percent was soil organic carbon to $1 \mathrm{~m}$ depth, 24 percent was live biomass (above and below ground), and 5 percent was dead biomass (a combination of litter and downed woody debris).

- Hawai'i Island, the largest island in the Hawaiian archipelago, stored $136 \mathrm{TgC}$, which accounted for 58 percent of the total carbon storage in the State of Hawai' $i$. The island of Kaua' $i$ had the highest carbon density (carbon storage per unit area), estimated as $23.5 \mathrm{kgC} / \mathrm{m}^{2}$, followed by $\mathrm{O}^{\prime}$ ahu $\left(20.5 \mathrm{kgC} / \mathrm{m}^{2}\right)$, Maui $\left(17.1 \mathrm{kgC} / \mathrm{m}^{2}\right)$, Moloka'i $\left(16.1 \mathrm{kgC} / \mathrm{m}^{2}\right)$, and Hawai' $\mathrm{i}$ Island $\left(14.0 \mathrm{kgC} / \mathrm{m}^{2}\right)$.

- Live-biomass carbon storage in native forests was estimated as $32 \mathrm{TgC}$, which was 51 percent of all carbon stored as live biomass $(63 \mathrm{TgC})$, followed by invaded forests $(21 \mathrm{TgC})$ and alien tree plantations $(6 \mathrm{TgC})$.

- Between 2003 and 2014, gross primary production (GPP) across the seven islands averaged $20.2 \mathrm{TgC} / \mathrm{yr}$, with Hawai' $i$ Island accounting for 55 percent of this flux (11.2 TgC/yr). As was the case with carbon storage, the island of Kaua' $i$ had the highest mean annual GPP carbon flux density (GPP per unit land area), estimated

\footnotetext{
${ }^{1}$ U.S. Geological Survey.

${ }^{2}$ U.S. Department of Agriculture Forest Service.

${ }^{3}$ Carnegie Institution for Science.

${ }^{4}$ University of Hawai' $i$ at Hilo.

${ }^{5}$ University of Montana.

${ }^{6}$ University of Hawai' $\mathrm{i}$.
}

at $1.85 \mathrm{kgC} / \mathrm{m}^{2}$, followed by Moloka'i $\left(1.68 \mathrm{kgC} / \mathrm{m}^{2}\right)$, $\mathrm{O}^{\prime}$ ahu $\left(1.47 \mathrm{kgC} / \mathrm{m}^{2}\right)$, Maui $\left(1.34 \mathrm{kgC} / \mathrm{m}^{2}\right)$, and Hawai' $\mathrm{i}$ Island $\left(1.07 \mathrm{kgC} / \mathrm{m}^{2}\right)$.

- Between 2003 and 2014, the estimates of annual net ecosystem production (NEP) in terrestrial ecosystems across the seven islands averaged $2.38 \mathrm{TgC} / \mathrm{yr}$ (a positive value denotes a carbon sink). Among ecosystem types, native forests represented the largest single terrestrial carbon sink with NEP of $1.26 \mathrm{TgC} / \mathrm{yr}$, which accounted for 53 percent of total annual carbon sequestration. Alien grasslands were estimated to be a net carbon source to the atmosphere with NEP estimated at $-0.56 \mathrm{TgC} / \mathrm{yr}$, because ecosystem respiration exceeded GPP in large areas of alien dry grasslands.

\subsection{Introduction}

Terrestrial ecosystems in the tropics have the potential to be major carbon sinks, yet intensive land use and development can reduce that potential or even convert these ecosystems to net carbon sources to the atmosphere. Because of its steep environmental gradients and geological history, Hawai' $i$ has been home to several plot- and stand-level studies examining the physical and biological controls over tropical ecosystem carbon storage and flux, with a focus on soils, live biomass, and plant productivity (Townsend and others, 1995; Torn and others, 1997; Aplet and others, 1998; Herbert and Fownes, 1999; Schuur and others, 2001; Schuur and Matson, 2001; Giardina and others, 2003; Litton and others, 2006; Selmants and others, 2014; Giardina and others, 2014). More recently several landscapelevel studies on the Island of Hawai' $i$ have examined biotic and environmental controls on aboveground carbon density (ACD) (Asner, Hughes, and others, 2009, Asner and others, 2010, Hughes and others, 2014), including the first whole-island estimate of aboveground carbon stocks for one of the main Hawaiian Islands (Asner and others, 2011). These landscape-scale studies integrated much of the previous research conducted at the plot scale but focused on a limited set of carbon pools or fluxes. 
This chapter represents the first comprehensive assessment of terrestrial-ecosystem carbon stocks and fluxes across the main Hawaiian Islands in an effort to better understand how carbon stocks and fluxes vary by ecosystem component across islands and among ecosystem types. The goal of this chapter is to provide robust baseline estimates of carbon storage and fluxes across the Hawaiian Islands based on the best available data. This baseline data will then be used as input to predict how terrestrial carbon cycling may respond to projected future changes in land use, land cover, disturbance, and climate (see Sleeter and others, this volume, chap. 8).

Conventional carbon cycle terminology (Chapin and others, 2006) was used in this chapter and throughout this report, as noted in Giardina and others (this volume, chap. 1). Of particular relevance here is the concept of net ecosystem production (NEP), which is defined as the imbalance between gross primary production (GPP) and ecosystem respiration $\left(R_{\mathrm{e}}\right)$. For this report, NEP was estimated by subtracting $R_{\mathrm{e}}$ from GPP, therefore, a positive value indicates carbon accumulation or sequestration within an ecosystem (a net carbon sink), and a negative value indicates a loss of carbon from the ecosystem to the atmosphere (a net carbon source). This definition is consistent with that suggested by Chapin and others (2006).

\subsection{Input Data and Methods}

\subsubsection{Carbon Storage}

Input data, along with the data sources, used to estimate carbon storage in terrestrial ecosystems of Hawai' $i$ are listed in table 6.1. Each input dataset was converted to a standard projection and data format. For this report, estimated carbon stocks include aboveground live-biomass carbon, live-root-biomass carbon, dead-biomass carbon (the sum of surface litter and downed woody debris carbon), and soil organic carbon (SOC). Live- and dead-biomass carbon stocks were estimated only for forests (including alien tree plantations), grasslands, shrublands, and barren-to-sparsely vegetated areas as delineated by the land-cover map from Jacobi and others (this volume, chap. 2). Collectively, these four land-cover types constitute about 88 percent of the total land area of the main Hawaiian Islands. Developed areas (6 percent of total land area), agriculture (5 percent of total land area), and wetlands (1 percent of total land) made up the remaining 12 percent of land area for which there was insufficient Hawai' $i$-specific data to estimate carbon storage in live and dead biomass. SOC data covers 100 percent of the land area on the seven main Hawaiian Islands, so we included SOC data from developed areas, agriculture, and wetlands in islandwide and statewide estimates of ecosystem carbon storage. Land-cover classes from Jacobi and others (this volume, chap. 2) were aggregated into broader categories for ease of analysis and interpretation. Specifically, all grasslands were combined into a single grassland category, all shrublands were combined into a single shrubland category, alien and mixed forest types were combined into an "invaded forest" category, and mesic and wet forests were combined into a "mesic and wet forest" category.

Aboveground biomass carbon of forest ecosystems for each island and forest cover type was estimated using a new map of forest ACD across the seven main Hawaiian Islands (Asner and others, 2016). The forest ACD map was constructed using a combination of airborne light detection and ranging (lidar) data from Hawai' $i$ Island, freely available satellite data covering all the major islands, and the land-cover map described in Jacobi and others (this volume, chap. 2). Lidar estimates of forest top-ofcanopy height (TCH) covering $3,793 \mathrm{~km}^{2}$ over all major forest types on Hawai' i Island (Asner and others, 2011) was used to train a geospatial model that incorporated forest canopy fractional cover and other structural metrics derived from Landsat data as well as several environmental factors (Asner, Knapp, and others,

Table 6.1. Input data used to estimate carbon storage in terrestrial ecosystems of Hawai'i.

[LULC, land use and land cover]

\begin{tabular}{lll}
\hline \multicolumn{1}{c}{ Data category } & \multicolumn{1}{c}{ Data type } & \multicolumn{1}{c}{ Data source } \\
\hline LULC & LULC classes & Jacobi and others (this volume, chap. 2) \\
Soils & Soil organic carbon & gSSURGO (Soil Survey Staff, 2015) \\
Forests, tree plantations & $\begin{array}{l}\text { Aboveground biomass carbon } \\
\text { Litter carbon }\end{array}$ & $\begin{array}{l}\text { Asner and others (2016) } \\
\end{array}$ \\
& Downed woody debris carbon & Hawbaker and others (this volume, chap. 5) \\
& Hawbaker and others (this volume, chap. 5) \\
\hline Shrublands, grasslands & Aboveground biomass carbon & Hawbaker and others (this volume, chap. 5) \\
& $\begin{array}{l}\text { Litter carbon } \\
\text { Downed woody debris carbon }\end{array}$ & Hawbaker and others (this volume, chap. 5) \\
& Hawbaker and others (this volume, chap. 5) \\
\hline
\end{tabular}


2009). This model was then applied to all the islands using the same set of canopy structural and environmental metrics to yield a multi-island map of forest $\mathrm{TCH}$ at 30-m spatial resolution. A landscape-level equation relating TCH to ACD was applied, resulting in a forest ACD map at 30-m resolution for the seven main Hawaiian Islands. This statewide ACD map was validated using ground-level estimates of ACD derived from Forest Inventory and Analysis plots maintained by the U.S. Department of Agriculture Forest Service that were located on Hawai'i i Island, Maui, Moloka'i, O'ahu, and Kaua'i. See Asner and others (2016) for a more detailed description of the Hawai' $i$ forest ACD map.

Aboveground biomass carbon in shrublands and grasslands was estimated by multiplying median values for each biome type (from the biomass database in Hawbaker and others, this volume, chap. 5) by the land area of that biome type as delineated by the land-use and land-cover (LULC) map from Jacobi and others (this volume, chap. 2). Litter and downed-woody-debris carbon were estimated for forests, shrublands, and grasslands by taking the median values for each biome type in the biomass database from Hawbaker and others (this volume, chap. 5) and multiplying by the land area covered by that biome type.

Live-root biomass for forests and tree plantations was estimated using the power law equation listed in table 6.2 (Mokany and others, 2006). Root-to-shoot ratios of tropical grasslands are typically much lower than those of temperate grasslands (Mokany and others, 2006), and the root-to-shoot ratios of the African grass species that dominate Hawaiian grasslands are lower still because of their high biomass allocation to leaves (Williams and Black, 1994; Williams and Baruch, 2000; Neto and others, 2012). Live-root-biomass carbon of grasslands in Hawai' $i$ was estimated by averaging the global median root-to-shoot ratio for tropical and subtropical grasslands (Mokany and others, 2006) with published root-to-shoot ratios of native and alien African grasses in Hawai' $i$ (Williams and Black, 1994; Neto and others, 2012) and then multiplying this derived root-to-shoot ratio by the estimate of aboveground live-biomass carbon for Hawaiian grasslands (table 6.2). A similar approach was used to estimate live-biomass carbon of shrublands. The global median root-to-shoot values for shrubland and tropical arid shrubland/desert were averaged and then multiplied by the estimate of aboveground live-biomass carbon for Hawaiian shrublands (table 6.2).

Estimates of SOC to a depth of $1 \mathrm{~m}$ at $10-\mathrm{m}$ spatial resolution were derived from the USDA Natural Resources Conservation Service (NRCS) gridded Soil Survey Geographic (gSSURGO) Database (Soil Survey Staff, 2015) for the State of Hawai' $i$. The spatial resolution of the gSSURGO dataset was resampled to 30-m raster cell size in Esri ArcGIS ver. 10.1 to align with the spatial resolution of the LULC map from Jacobi and others (this volume, chap. 2). Unlike other datasets used to estimate carbon stocks, the gSSURGO dataset covers the entire land area of the seven islands included in this report, including developed areas, agriculture areas, and wetlands. Soil organic carbon data for all land-cover types was included in islandwide and statewide estimates of SOC and total ecosystem carbon storage.
Table 6.2. Equation or ratio used to estimate live-root biomass from aboveground live biomass by ecosystem type.

[y = root live biomass; $\mathrm{x}=$ aboveground live biomass $]$

\begin{tabular}{lll}
\hline \multicolumn{1}{c}{ Ecosystem } & $\begin{array}{c}\text { Equation or } \\
\text { Ratio }\end{array}$ & \multicolumn{1}{c}{ Source } \\
\hline $\begin{array}{c}\text { Forests, tree } \\
\text { plantations }\end{array}$ & $\mathrm{y}=0.489 \mathrm{x}^{0.89}$ & Mokany and others (2006) \\
$\begin{array}{c}\text { Shrublands } \\
\text { Grasslands }\end{array}$ & 1.45 & Mokany and others (2006) \\
& 0.73 & $\begin{array}{c}\text { Williams and Black (1994), } \\
\text { Mokany and others (2006), } \\
\text { Neto and others (2012) }\end{array}$ \\
\hline
\end{tabular}

\subsubsection{Carbon Fluxes}

GPP on the seven islands included in this report was estimated using data and algorithms from the Moderate Resolution Imaging Spectroradiometer (MODIS) project (Running and others, 2004; Zhao and others, 2005). MODISderived estimates of GPP (MOD17) use time series of the fraction of absorbed photosynthetically active radiation (fAPAR) and regional coarse-resolution meteorological data as inputs and then use biome-specific radiation-use efficiency (ع) coefficients to translate absorbed photosynthetically active radiation (APAR) in energy units to GPP, the total mass of carbon fixed by photosynthesis per unit area per unit time. For this report, the global MOD17 algorithm was adapted by incorporating the Hawai' $i$-specific land-cover map from Jacobi and others (this volume, chap. 2), locally derived 250-m-resolution meteorological data, and 500-m-resolution MODIS ver. 6 fAPAR data processed with a specifically adapted filtering and gap-filling technique to deal with the high prevalence of clouds in some areas.

The MOD17 algorithm relies heavily on accurate representations of land-cover type to apply biome-specific values of $\varepsilon$. Globally, the MODIS land-cover product (MOD12Q1) is accurate to within $65-80$ percent, with higher accuracies in pixels that are largely homogeneous. However, Hawai' $i$ is a discontinuous landmass with very heterogeneous land cover. To maximize the accuracy of land-cover-type assignment, a Hawai ${ }^{i} \mathrm{i}$ specific biome map was developed by re-sampling the carbon assessment for Hawai ' $\mathrm{i}$ (CAH) land-cover map (Jacobi and others, this volume, chap. 2) to 500-meter pixel resolution using the majority method in ArcGIS ver. 10.2.2 and then assigning each HIGAP vegetation type to 1 of the 16 land-cover classes in MOD12Q1. This Hawai' i-specific biome map represented a substantial improvement in land-cover classification compared to the MOD12Q1 product; there was only about a 50 percent agreement between the two overall, with about 86 percent agreement for broadleaf evergreen forest, 27 percent agreement for grasslands, and 25 percent agreement for shrublands (table 6.1).

The MOD17 algorithm uses air temperature $\left(\mathrm{T}_{\text {air }}\right)$ and vapor pressure deficit (VPD) data to calculate attenuating scalars to produce a biome-specific radiation-use efficiency coefficient, $\varepsilon$. The biome-specific values for $\varepsilon$ are combined 
with estimates of APAR to calculate GPP, where APAR is calculated as

$$
\mathrm{APAR}=\text { incident PAR } \times \text { fAPAR }
$$

where incident PAR is estimated by multiplying incident shortwave radiation by 0.45 , and fAPAR is the fraction of absorbed photosynthetically active radiation.

Normally, coarse-resolution $T_{\text {air }}, V P D$, and incident shortwave radiation data from the NASA GMAO dataset are used for these calculations. For this report, mean monthly $\mathrm{T}_{\text {air }}, \mathrm{VPD}$, and incident shortwave radiation at $250-\mathrm{m}$ pixel resolution from the Climate Atlas of Hawai' $i$ (Giambelluca and others, 2014) were degraded to 500-m pixel resolution and used to calculate APAR and attenuating scalars for $\varepsilon$. Finally, the fAPAR time series was processed with an iteratively reweighted local regression filter (LOESS) to reduce noise and fill gaps caused by persistent cloud cover in some areas of the seven main Hawaiian Islands (Moreno and others, 2014). The resulting estimate of mean annual GPP represents a 10-year period from 2004 to 2013.

Estimates of $R_{\mathrm{e}}$ and NEP were calculated by modeling the relationship between GPP and $R_{\mathrm{e}}$ from literature values and applying these relationships to the MODIS-derived estimate of mean annual GPP for the seven main Hawaiian Islands. A grid of points at 500-m distance centered on each MODIS pixel was intersected with the MODIS GPP data layer, and GPP values were extracted to these points using ArcGIS ver. 10.1. Regression equations of the relationship between GPP and $R_{\mathrm{e}}$ were derived based on published values from broad-leaved evergreen forests, grasslands, and other ecosystems (table 6.3). These regression equations were applied to the GPP point values across the seven islands included in this report to estimate $R_{\mathrm{e}}$, and NEP for each point was estimated by subtracting $R_{\mathrm{e}}$ from GPP. The grid of points with $R_{\mathrm{e}}$ and NEP values assigned was then rasterized at 500-m resolution using ArcGIS ver. 10.1.

\subsection{Results and Discussion}

\subsubsection{Baseline Carbon Stocks}

Statewide, the total carbon storage in terrestrial ecosystems of Hawai ${ }^{i}$, including live biomass (fig. 6.1 for forest ACD), litter, downed woody debris, and SOC (fig. 6.2), was estimated to be $258 \mathrm{TgC}$ (table 6.4). Approximately 70 percent of total carbon was stored as SOC, with about 25 percent of carbon stored as live biomass (both above and below ground) and about 5 percent of carbon stored as dead biomass (litter and downed woody debris; table 6.4). Total carbon storage by island was largely a function of island area (table 6.4). Hawai' $i$ Island, which is larger than the combined area of the other six islands, stored the most carbon at $146 \mathrm{TgC}$, followed by Kaua'i, Maui, and O'ahu, each of which stored about $30 \mathrm{TgC}$ (table 6.3). Kaua'i, the oldest of the seven major islands, had the highest total ecosystem carbon density (in other words, the amount of carbon per unit area, derived from values in table 6.4 ) at $23.5 \mathrm{kgC} / \mathrm{m}^{2}$, followed by $\mathrm{O}^{\prime} \mathrm{ahu}\left(20.5 \mathrm{kgC} / \mathrm{m}^{2}\right)$, Maui $\left(17.1 \mathrm{kgC} / \mathrm{m}^{2}\right)$, and Moloka' $\mathrm{i}$ $\left(16.1 \mathrm{kgC} / \mathrm{m}^{2}\right)$. Although Hawai' $i$ Island stored the most carbon

Table 6.3. Regression equations based on published values used to estimate ecosystem respiration from gross primary production by ecosystem type.

$\left[R^{2}\right.$, ordinary least squares coefficient of determination; $\mathrm{N}$, sample size; $R_{\mathrm{e}}$, ecosystem respiration; GPP, gross primary production]

\begin{tabular}{llrrl}
\multicolumn{1}{c}{ Ecosystem } & \multicolumn{1}{c}{ Equation } & $R^{2}$ & N & Source \\
\hline Forests, tree plantations & $R_{\mathrm{e}}=1.048 \times \mathrm{GPP}-0.5078$ & 0.81 & 25 & Lasslop and others (2010), Yuan and others (2011) \\
Shrublands & $R_{\mathrm{e}}=0.8767 \times \mathrm{GPP}-0.0839$ & 0.77 & 145 & Lasslop and others (2010) \\
Grasslands & $R_{\mathrm{e}}=0.8325 \times \mathrm{GPP}+0.4091$ & 0.80 & 45 & Wolf and others (2011), Yuan and others (2011) \\
\hline
\end{tabular}

Table 6.4. Estimates of ecosystem carbon stored in Hawai'i by carbon pool for each island.

[Island-wide and total soil organic carbon (SOC) estimates include SOC data from developed areas, agriculture, and wetlands. DWD, downed woody debris; $\underline{\mathrm{TgC} \text {, teragrams of carbon] }}$

\begin{tabular}{|c|c|c|c|c|c|c|}
\hline Island & Area $\left(\mathrm{km}^{2}\right)$ & $\begin{array}{l}\text { Aboveground live } \\
\text { biomass }(\mathrm{TgC})\end{array}$ & $\begin{array}{c}\text { Root live } \\
\text { biomass (TgC) }\end{array}$ & $\begin{array}{l}\text { Litter and DWD } \\
\qquad(\mathrm{TgC})\end{array}$ & $\begin{array}{l}\text { SOC } \\
(\mathrm{TgC})\end{array}$ & $\begin{array}{c}\text { Total ecosystem } \\
\text { carbon }(\mathrm{TgC})\end{array}$ \\
\hline Hawai‘i & 10,453 & 24.6 & 10.7 & 6.5 & 104.3 & 146.1 \\
\hline Kaho'olawe & 115 & 0.2 & 0.1 & 0.1 & 0.4 & 0.8 \\
\hline Kaua'i & 1,428 & 6.0 & 2.4 & 1.3 & 23.8 & 33.5 \\
\hline Lāna'i & 365 & 0.3 & 0.1 & 0.2 & 2.1 & 2.7 \\
\hline Maui & 1,898 & 5.5 & 2.2 & 1.4 & 23.4 & 32.5 \\
\hline Moloka'i & 672 & 1.7 & 0.8 & 0.4 & 7.9 & 10.8 \\
\hline O`ahu & 1,539 & 5.9 & 2.4 & 1.2 & 22.0 & 31.5 \\
\hline Total & 16,470 & 44.2 & 18.7 & 11.0 & 184.0 & 257.9 \\
\hline
\end{tabular}




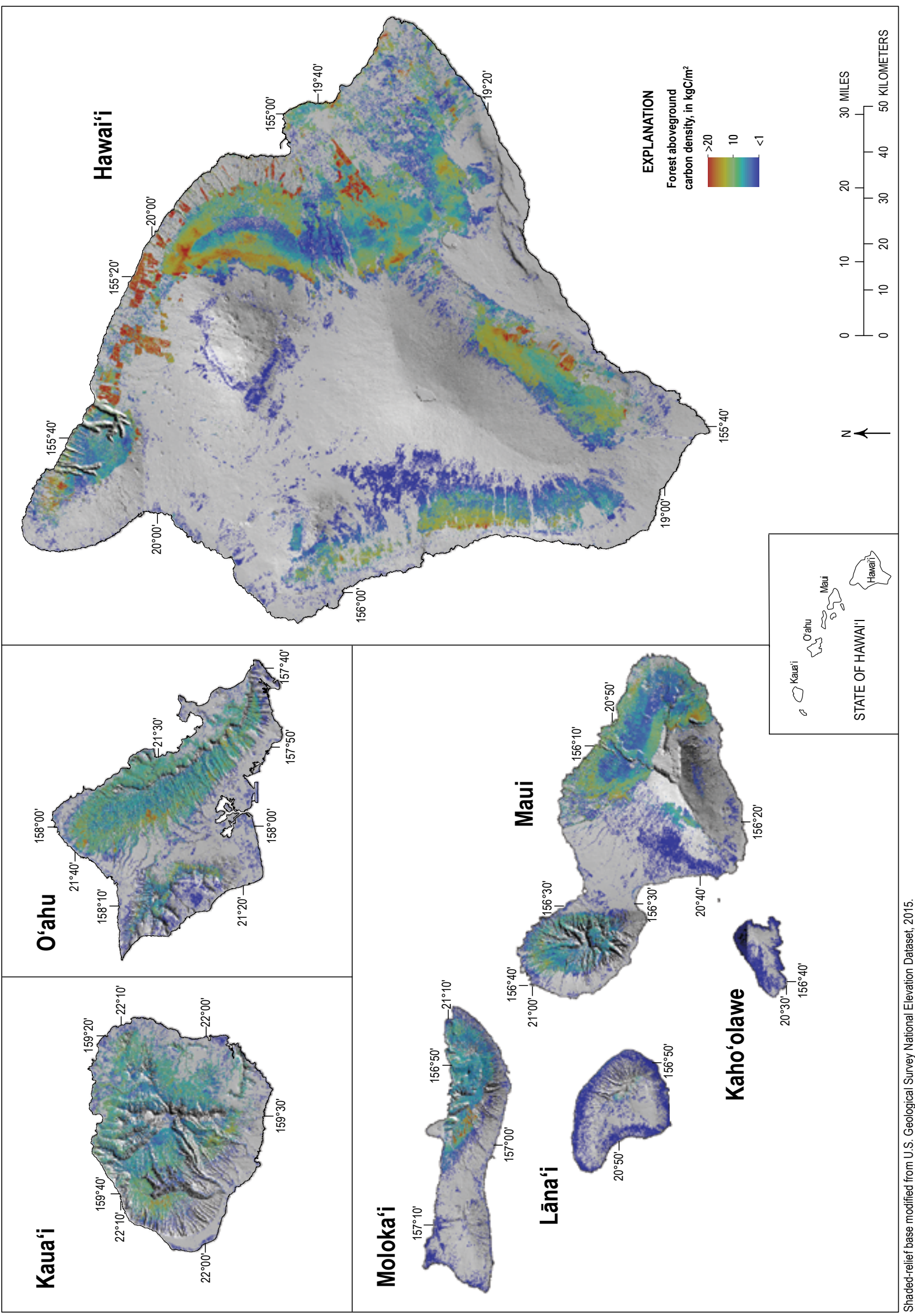

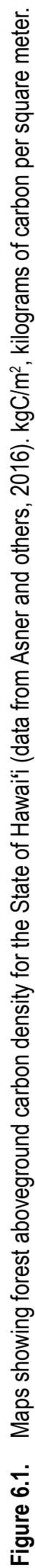




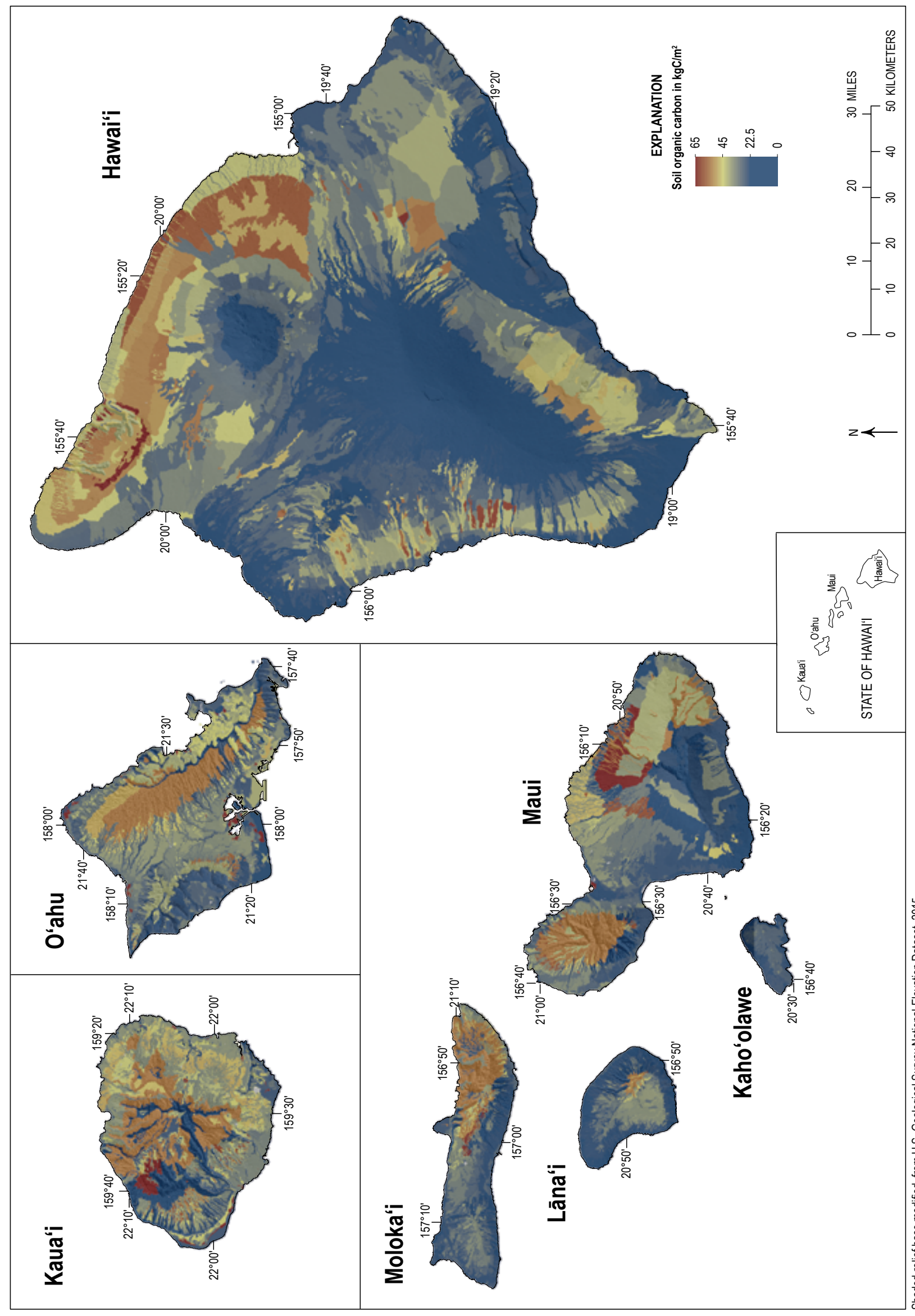

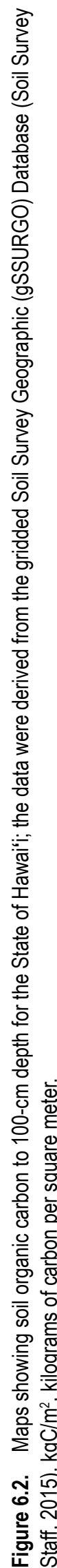


overall, its estimated carbon density of $14 \mathrm{kgC} / \mathrm{m}^{2}$ was low compared to other islands because approximately 27 percent of its total land area $\left(\sim 2,800 \mathrm{~km}^{2}\right)$ is classified as "bare ground" consisting of alpine tundra and relatively recent lava flows with sparse vegetation and little to no soil development (see Jacobi and others, this volume, chap. 2). Only Kaho'olawe and Lāna' $i$ $\left(\sim 7 \mathrm{kgC} / \mathrm{m}^{2}\right.$ each), both relatively arid islands with long histories of land-cover conversion, had carbon densities lower than Hawai'i Island.

Native mesic and wet forests stored the highest amount of total carbon among ecosystem types, estimated as $96.3 \mathrm{TgC}$. Approximately 61 percent of the total carbon in native mesic and wet forests was in soil, 33 percent in live biomass, and 6 percent in dead biomass (table 6.5). In contrast, grasslands, shrublands, and bare ground, which together cover nearly three times the total area of native mesic and wet forests, combined to store a total of only $67.9 \mathrm{TgC}$, about 30 percent less than in native mesic and wet forests (table 6.5). Total carbon of invaded mesic and wet forests was about half the total carbon stored in native mesic and wet forests ( $49.6 \mathrm{TgC}$ ), primarily because invaded mesic and wet forests covered about half the total land area of native mesic and wet forests. Of total carbon in invaded mesic and wet forests, approximately 56 percent was in soil, 39 percent was in live biomass, and 5 percent was in dead biomass - a distribution similar to that of native mesic and wet forests. Invaded mesic and wet forests had a similar overall carbon density as native mesic and wet forests ( 31 and $32 \mathrm{kgC} / \mathrm{m}^{2}$, respectively). Native and invaded dry forests also had similar total carbon densities, estimated as 7.6 and $8.3 \mathrm{kgC} / \mathrm{m}^{2}$, respectively, but invaded dry forests had a higher proportion of total carbon in live biomass (24 percent) compared to native dry forests (13 percent). Alien tree plantations had the highest total carbon density of any ecosystem type, estimated as $45.7 \mathrm{kgC} / \mathrm{m}^{2}$, but constituted a relatively small land area $\left(243 \mathrm{~km}^{2}\right)($ table 6.5$)$. In contrast, bare ground covered the largest land area of the ecosystem types listed in table 6.5 , but had the lowest estimated total carbon density at $1.9 \mathrm{kgC} / \mathrm{m}^{2}$.

\subsubsection{Baseline Carbon Fluxes}

Mean annual GPP of terrestrial ecosystems in the State of Hawai' $i$ was estimated as $20.2 \mathrm{TgC} / \mathrm{yr}$ for the years 2003-2014 (fig. 6.3; table 6.6). Approximately 88 percent of the carbon fixed annually by GPP was respired back to the atmosphere (17.8 TgC/yr) as the combination of autotrophic and heterotrophic respiration. Terrestrial ecosystems of Hawai' $i$

Table 6.5. Estimates of ecosystem carbon stored in Hawai'i by carbon pool for each ecosystem type.

[DWD, downed woody debris; SOC, soil organic carbon; TgC, teragrams of carbon]

\begin{tabular}{|c|c|c|c|c|c|c|}
\hline Ecosystem & Area $\left(\mathrm{km}^{2}\right)$ & $\begin{array}{l}\text { Aboveground live } \\
\text { biomass }(\mathrm{TgC})\end{array}$ & $\begin{array}{c}\text { Root live } \\
\text { biomass (TgC) }\end{array}$ & $\begin{array}{l}\text { Litter and DWD } \\
(\mathrm{TgC})\end{array}$ & $\begin{array}{l}\text { SOC } \\
(\mathrm{TgC})\end{array}$ & $\begin{array}{c}\text { Total ecosystem } \\
\text { carbon }(\mathrm{TgC})\end{array}$ \\
\hline Native dry forest & 302 & 0.2 & 0.1 & 0.2 & 1.8 & 2.3 \\
\hline Invaded dry forest & 635 & 1.0 & 0.5 & 0.5 & 3.6 & 5.6 \\
\hline Native mesic-wet forest & 3,148 & 22.8 & 9.0 & 5.6 & 58.9 & 96.3 \\
\hline Invaded mesic-wet forest & 1,529 & 13.9 & 5.3 & 2.7 & 27.6 & 49.5 \\
\hline Alien tree plantations & 243 & 4.4 & 1.6 & 0.3 & 5.1 & 11.4 \\
\hline Shrublands & 2,719 & 1.2 & 1.7 & 1.0 & 20.6 & 24.5 \\
\hline Grasslands & 2,783 & 0.7 & 0.5 & 0.6 & 35.6 & 37.4 \\
\hline Bare (sparse vegetation) & 3,111 & $<0.1$ & $<0.1$ & 0.1 & 5.7 & 5.9 \\
\hline Total & 14,470 & 44.2 & 18.7 & 11.0 & 158.9 & 232.9 \\
\hline
\end{tabular}

Table 6.6. Estimates of gross primary production, ecosystem respiration, and net ecosystem production by island.

[Data are mean annual fluxes for the years 2004-2013. GPP, gross primary production; $R_{\mathrm{e}}$, ecosystem respiration; NEP, net ecosystem production; $\mathrm{TgC} / \mathrm{yr}$, teragrams of carbon per year]

\begin{tabular}{|c|c|c|c|c|}
\hline Island & Area $\left(\mathrm{km}^{2}\right)$ & GPP (TgC/yr) & $R_{\mathrm{e}}(\mathrm{TgC} / \mathrm{yr})$ & NEP (TgC/yr) \\
\hline Hawai‘i & 10,453 & 11.19 & 10.02 & 1.17 \\
\hline Kaho'olawe & 115 & 0.06 & 0.05 & 0.01 \\
\hline Kaua'i & 1,429 & 2.64 & 2.29 & 0.35 \\
\hline Lāna'i & 365 & 0.37 & 0.32 & 0.05 \\
\hline Maui & 1,898 & 2.54 & 2.25 & 0.29 \\
\hline Moloka'i & 672 & 1.13 & 0.93 & 0.20 \\
\hline O`ahu & 1,539 & 2.26 & 1.94 & 0.32 \\
\hline Total & 16,470 & 20.19 & 17.81 & 2.38 \\
\hline
\end{tabular}



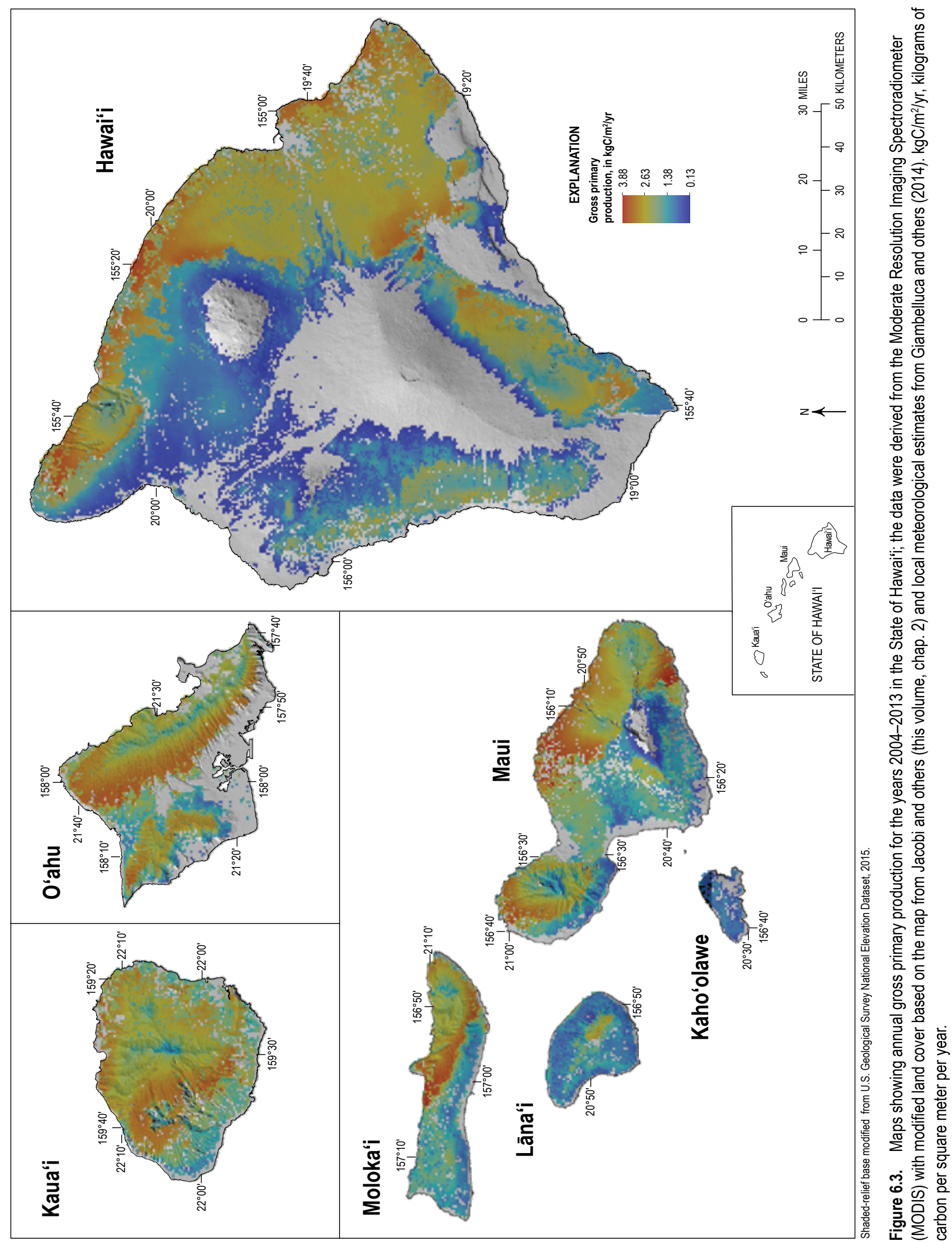
were estimated to sequester an average of $2.38 \mathrm{TgC} / \mathrm{yr}$ for the years 2003-2014. Similar to trends for carbon storage, total annual carbon fluxes by island were largely a function of island area. Hawai' $i$ Island, the largest of the seven islands considered in this report ( $\sim 64$ percent of the total land area), was estimated to have the highest mean annual GPP $(11.2 \mathrm{TgC} / \mathrm{yr})$ and $R_{\mathrm{e}}$ ( $10 \mathrm{TgC} / \mathrm{yr}$ ) for the period 2003-2014. Hawai $i \mathrm{I}$ Island was also the largest carbon sink with an estimated mean annual NEP of $1.17 \mathrm{TgC} / \mathrm{yr}$, which represented approximately 50 percent of the total annual terrestrial-ecosystem carbon sink of the seven main Hawaiian Islands. Maui, $\mathrm{O}^{\prime}$ ahu, and Kaua'i each represented approximately $8-12$ percent of the total land area of the seven islands considered in this report, and each contributed approximately 10-14 percent of the estimated total carbon sink. Collectively, the islands of Maui, $\mathrm{O}^{\prime} \mathrm{ahu}$, and Kaua' $\mathrm{i}$ accounted for about 37 percent of both GPP and NEP. Kaua' $i$ had the highest GPP carbon flux density (carbon flux per unit area), estimated at $1.85 \mathrm{kgC} / \mathrm{m}^{2} / \mathrm{yr}$. Although Hawai' $i$ Island exhibited the highest total GPP, its estimated GPP carbon flux density was only $1.1 \mathrm{kgC} / \mathrm{m}^{2} / \mathrm{yr}$, approximately 40 percent lower than that of Kaua'i. Only Lāna'i $\left(1.0 \mathrm{kgC} / \mathrm{m}^{2} / \mathrm{yr}\right)$ and Kaho'olawe

$\left(0.5 \mathrm{kgC} / \mathrm{m}^{2} / \mathrm{yr}\right)$ had lower GPP carbon flux densities than Hawai' $i$ Island. Carbon-sink strength per unit area (NEP carbon flux density) followed a similar pattern; Kaua' $i$ was estimated to have the highest carbon-sink strength per unit area (NEP carbon flux density $=0.25 \mathrm{kgC} / \mathrm{m}^{2} / \mathrm{yr}$ ), and Kaho'olawe had the lowest carbon-sink strength per unit area (NEP carbon flux density $=$ $0.09 \mathrm{kgC} / \mathrm{m}^{2} / \mathrm{yr}$ ).

Native mesic and wet forests accounted for approximately 35 percent of total terrestrial GPP, and invaded mesic and wet forests and grasslands each accounted for 16-18 percent of total GPP (table 6.7). Native mesic and wet forests represented the largest carbon sink of any ecosystem type, accounting for approximately 50 percent of estimated mean annual NEP for the years 2003-2014 (table 6.7). In contrast, grasslands were estimated to be a net carbon source to the atmosphere for the years 2003-2014 because $R_{\mathrm{e}}$ exceeded GPP in dry grasslands (fig. 6.4).

Table 6.7. Estimates of gross primary production, ecosystem respiration, and net ecosystem production by ecosystem type.

[Data are mean annual fluxes for the years 2004-2013. GPP, gross primary production; $R_{\mathrm{e}}$, ecosystem respiration; $\mathrm{NEP}$, net ecosystem production; $\mathrm{TgC} / \mathrm{yr}$, teragrams of carbon per year]

\begin{tabular}{lcccc}
\hline \multicolumn{1}{c}{ Ecosystem } & Area $\left(\mathrm{km}^{2}\right)$ & $\begin{array}{c}\text { GPP } \\
(\mathrm{TgC} / \mathrm{yr})\end{array}$ & $\begin{array}{c}\boldsymbol{R}_{\mathrm{e}} \\
(\mathrm{TgC} / \mathrm{yr})\end{array}$ & $\begin{array}{c}\text { NEP } \\
(\mathrm{TgC} / \mathrm{yr})\end{array}$ \\
\hline Native dry forest & 302 & 0.34 & 0.25 & 0.09 \\
\hline Invaded dry forest & 635 & 0.70 & 0.60 & 0.11 \\
\hline Native mesic-wet forest & 3,148 & 7.05 & 5.89 & 1.17 \\
Invaded mesic-wet forest & 1,529 & 3.63 & 3.13 & 0.50 \\
Alien tree plantations & 243 & 0.65 & 0.54 & 0.11 \\
Shrublands & 2,719 & 4.65 & 3.69 & 0.96 \\
Grasslands & 2,783 & 3.17 & 3.72 & -0.56 \\
\hline Bare (sparse vegetation) & 3,111 & 0 & 0 & 0 \\
\hline \multicolumn{1}{c}{ Total } & 14,470 & 20.19 & 17.81 & 2.38 \\
\hline
\end{tabular}




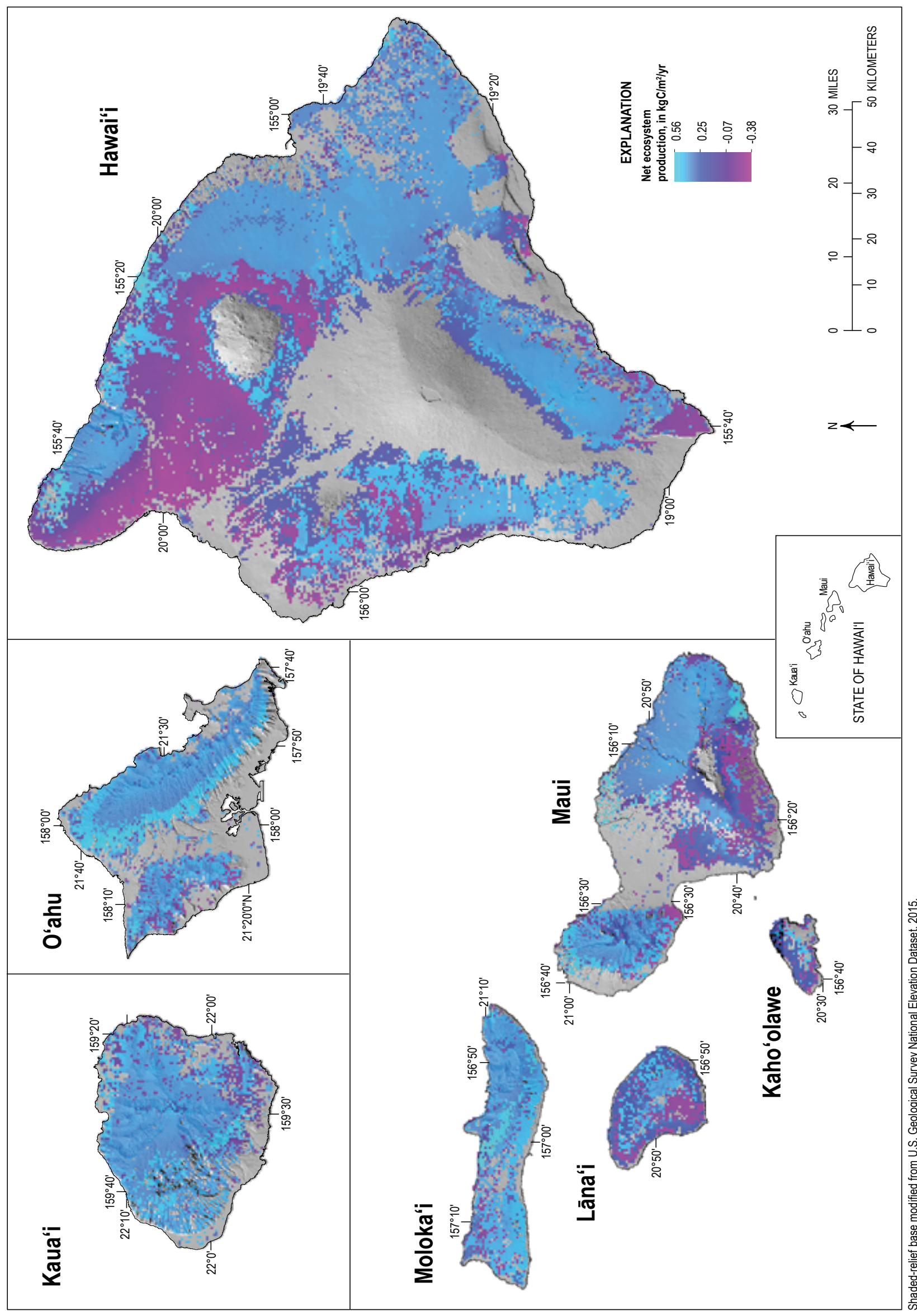

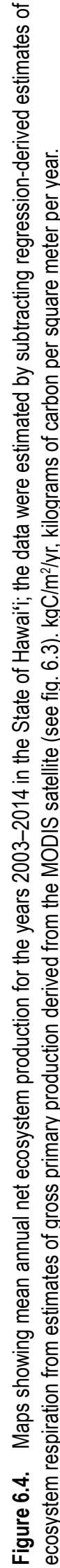




\subsection{Summary, Limitations, and Uncertainty}

Aside from the recently published statewide forest ACD map (Asner and others, 2016), previous efforts quantifying carbon stocks and fluxes in terrestrial ecosystems in Hawai $i$ i have been confined to the plot level (Herbert and Fownes, 1999; Schuur and others, 2001; Schuur and Matson, 2001; Giardina and others, 2003; Litton and others, 2006; Selmants and others, 2014; Giardina and others, 2014), the landscape level (Asner, Hughes, and others, 2009; Asner and others, 2010; Hughes and others, 2014), or, at most, the island level (Asner and others, 2011). This report represents the first comprehensive effort to quantify carbon stocks and carbon fluxes in terrestrial ecosystems across the seven main Hawaiian Islands.

Overall estimates of carbon storage are relatively well constrained, particularly data related to forest aboveground biomass carbon and SOC, but knowledge gaps exist. Estimates of forest aboveground biomass carbon were validated with statewide plot-level estimates (Asner and others, 2016). The current estimate of aboveground live-biomass carbon for Hawai ${ }^{i} i$ Island in this report $(22.8 \mathrm{TgC})$ is about 20 percent lower than a previous estimate of $28.3 \mathrm{TgC}$ made by Asner and others (2011). The SOC data product, which is a statewide interpolation of soil survey data points over several decades, represents the most detailed soil geographic data available for the State of Hawai ${ }^{i} i$. In contrast, published studies that provided plot-level estimates of shrubland and grassland aboveground live-biomass carbon and dead-biomass carbon (downed woody debris and litter) were not evenly distributed across islands or climatic zones, and so the islandwide and statewide estimates of these carbon stocks should be used with caution. Shrublands in particular are poorly represented in the dataset of published values (Hawbaker and others, this volume, chap. 5) relative to their land area. However, shrubland and grassland ecosystems typically have relatively low biomass carbon densities compared to forest ecosystems, and SOC makes up the majority of ecosystem carbon in shrublands and grasslands, so uncertainty related to biomass carbon storage in shrubland and grassland vegetation types is unlikely to exert substantial influence on islandwide or statewide estimates of total ecosystem carbon storage. Estimates of live-root biomass are derived from global root-to-shoot relationships for particular ecosystem types, and so any errors in estimates of aboveground biomass carbon are propagated to estimates of belowground live biomass. In addition, although there is no evidence that native and nonnative plant species in Hawai' $i$ differ in their root-to-shoot ratios from plant species found elsewhere, the global root-to-shoot relationships used to estimate live-root biomass may not accurately represent those of plants growing in the Hawaiian Islands. Finally, islandwide and statewide estimates of total ecosystem carbon storage do not include estimates of live biomass, litter, and downed-woody-debris carbon in agriculture, developed areas, and wetlands, which make up about 12 percent of land area statewide. Litter and downed-woody-debris carbon are likely minimal in agriculture and developed areas, and live-biomass carbon is transitory in agricultural areas and of low density in developed areas. Soil organic carbon likely makes up most ecosystem carbon in agriculture areas, developed areas, and wetlands, but the lack of data on live biomass and detritus carbon in these areas may have resulted in an underestimate of islandwide and statewide ecosystem carbon storage and overly high estimates of the proportion of ecosystem carbon stored as SOC.

There are currently no published islandwide or statewide estimates of carbon fluxes (for example, GPP, $R_{\mathrm{e}}, \mathrm{NEP}$ ) for the State of Hawai $i$, and so it was not possible to compare current estimates to previous efforts at similar scales. However, at the plot level, Giardina and others (2003) estimated whole-ecosystem carbon budgets for Eucalyptus (Eucalyptus saligna) plantations in multiple $900 \mathrm{~m}^{2}$ plots for several years on the windward side of the Island of Hawai' $i$. They estimated a mean annual GPP carbon flux density of $2.95 \mathrm{kgC} / \mathrm{m}^{2} / \mathrm{yr}$ (Giardina and others, 2003), which is 10 percent higher than statewide MODIS-derived estimates of GPP carbon flux density for alien tree plantations $\left(2.68 \mathrm{kgC} / \mathrm{m}^{2} / \mathrm{yr}\right)$, 25 percent higher than estimates for invaded mesic-to-wet forests $\left(2.37 \mathrm{kgC} / \mathrm{m}^{2} / \mathrm{yr}\right)$, and about 30 percent higher than native mesicto-wet forests $\left(2.24 \mathrm{kgC} / \mathrm{m}^{2} / \mathrm{yr}\right)$.

Estimates of $R_{\mathrm{e}}$ in this report are from regression equations based on the relationship between GPP and $R_{\mathrm{e}}$ derived from eddy flux towers, none of which were located in Hawai' $i$ (Lasslop and others, 2010; Wolf and others, 2011; Yuan and others, 2011). Therefore, statewide values of $R_{\mathrm{e}}$ and NEP may be the least well constrained of all carbon stock and flux estimates in this chapter. Plot-level estimates of $R_{\mathrm{e}}$ carbon flux density in Eucalyptus plantations from Giardina and others (2003) were higher $\left(2.27 \mathrm{kgC} / \mathrm{m}^{2} / \mathrm{yr}\right)$ than statewide estimates of $R_{\mathrm{e}}$ carbon flux density in both alien tree plantations $\left(2.22 \mathrm{kgC} / \mathrm{m}^{2} / \mathrm{yr}\right)$ and invaded mesic-to-wet forests $\left(2.05 \mathrm{kgC} / \mathrm{m}^{2} / \mathrm{yr}\right)$. However, plot-level estimates of $R_{\mathrm{e}}$ in young Eucalyptus plantations accounted for about 77 percent of GPP, whereas statewide estimates of carbon flux density for $R_{\mathrm{e}}$ in alien tree plantations and alien mesic-to-wet forests accounted for about 83-85 percent of GPP. The estimated statewide $R_{\mathrm{e}}$ carbon flux density in native mesic-to-wet forests was $1.87 \mathrm{kgC} / \mathrm{m}^{2} / \mathrm{yr}$, about 20 percent lower than the plot-level Eucalyptus estimates, but $R_{\mathrm{e}}$ made up a greater proportion of GPP in native mesic-to-wet forests (approximately 84 percent) than in the young Eucalyptus plantations (Giardina and others, 2003). Taken together, the comparative relationship of $R_{\mathrm{e}}$ and NEP among these forest types yields reasonable results. Older, more established forest stands should lose a greater proportion of GPP as respiration, given their higher proportion of structural tissues relative to leaf area and less efficient foliage caused by hydraulic limitation of water transport in taller trees. However, the eddy covariance technique generally underestimates $R_{\mathrm{e}}$ lost to the atmosphere on an annual basis, which may result in overestimates of NEP and annual carbon sequestration. This represents an important caveat to the estimates of $R_{\mathrm{e}}$ in this chapter, in addition to the fact that relationships between GPP and $R_{\mathrm{e}}$ are derived from eddy flux towers in ecosystems outside of Hawai' $i$.

The data on ecosystem carbon stocks and fluxes presented in this chapter should prove useful to the scientific community, land managers, and policy stakeholders in a variety of applications. However, caution should be exercised when using data and conclusions in this chapter by considering the constraints and uncertainties noted above. 


\subsection{References Cited}

Aplet, G.H, Hughes, R.F., and Vitousek, P.M., 1998, Ecosystem development on Hawaiian lava flows - biomass and species composition: Journal of Vegetation Science, v. 9, no. 1, p. 17-26, available at http://dx.doi.org/10.2307/3237219.

Asner, G.P., Hughes, R.F., Mascaro, J., Uowolo, A.L., Knapp, D.E., Jacobson, James, Kennedy-Bowdoin, T., and Clark, J.K., 2011, High-resolution carbon mapping on the millionhectare Island of Hawaii: Frontiers in Ecology and the Environment, v. 9, no. 8, p. 434-439, available at http://dx.doi. org/10.1890/100179.

Asner, G.P., Hughes, R.F., Varga, T.A., Knapp, D.E., and Kennedy-Bowdoin, T., 2009, Environmental and biotic controls over aboveground biomass throughout a tropical rain forest: Ecosystems, v. 12, no. 2, p. 261-278, available at http://dx.doi. org/10.1007/s10021-008-9221-5.

Asner, G.P., Knapp, D.E., Balaji, A., Paez-Acosta, G., 2009, Automated mapping of tropical deforestation and forest degradation - CLASlite: Journal of Applied Remote Sensing, v. 3, no. 1, p. 033543 , available at http://dx.doi. org/10.1117/1.3223675.

Asner, G.P., Martin, R.E., Knapp, D.E., and Kennedy-Bowdoin, T., 2010, Effects of Morella faya tree invasion on aboveground carbon storage in Hawaii: Biological Invasions, v. 12, no. 3, p. 477-494, available at http://dx.doi.org/10.1007/s10530-0099452-1.

Asner, G.P., Sousan, S., Knapp, D.E., Selmants, P.C., Martin, R.E., Hughes, R.F., and Giardina, C.P., 2016, Rapid forest carbon assessments of oceanic islands - a case study of the Hawaiian archipelago: Carbon Balance and Management, v. 11, no. 1, 13 p., available at http://dx.doi.org/10.1186/s13021-015-0043-4.

Chapin, F.S., III, Woodwell, G.M., Randerson, J.T., Rastetter, E.B., Lovett, G.M., Baldocchi, D.D., Clark, D.A., Harmon, M.E., Schimel, D.S., Valentini, R., Wirth, C., Aber, J.D., Cole, J.J., Goulden, M.L., Harden, J.W., Heimann, M., Howarth, R.W., Matson, P.A., McGuire, A.D., Melillo, J.M., Mooney, H.A., Neff, J.C., Houghton, R.A., Pace, M.L., Ryan, M.G., Running, S.W., Sala, O.E., Schlesinger, W.H., and Schulze, E.D., 2006, Reconciling carbon-cycle concepts, terminology, and methods: Ecosystems, v. 9, no. 7, p. 1041-1050.

Giambelluca, T.W., Shuai, X., Barnes, M.L., Alliss, R.J., Longman, R.J., Miura, T., Chen, Q., Frazier, A.G., Mudd, R.G., Cuo, L., and Businger, A.D., 2014, Evapotranspiration of Hawai'i: final report to the U.S. Army Corps of EngineersHonolulu District and the Commission on Water Resource Management, State of Hawai'i, 178 p., available at http:// evapotranspiration.geography.hawaii.edu.
Giardina, C.P., Litton, C.M., Crow, S.E., and Asner, G.P., 2014, Warming-related increases in soil $\mathrm{CO}_{2}$ efflux are explained by increased below-ground carbon flux: Nature - Climate Change, v. 4, no. 9, p. 822-827, available at http://dx.doi.org/10.1038/ nclimate2322.

Giardina, C.P., Ryan, M.G., Binkley, D., and Fownes, J.H., 2003 , Primary production and carbon allocation in relation to nutrient supply in a tropical experimental forest: Global Change Biology, v. 9, no. 10, p. 1438-1450.

Herbert, D.A., and Fownes, J.H., 1999, Forest productivity and efficiency of resource use across a chronosequence of tropical montane soils: Ecosystems, v. 2, no. 3, p. 242-254.

Hughes, R.F., Asner, G.P., Mascaro, J., Uowolo, A., and Baldwin, J., 2014, Carbon storage landscapes of lowland Hawaii- the role of native and invasive species through space and time: Ecological Applications, v. 24, no. 4, p. 716-731, available at http://dx.doi.org/10.1890/12-2253.1.

Lasslop, G., Reichstein, M., Papale, D., Richardson, A.D., Arneth, A., Barr, A., Stoy, P., and Wohlfahrt, G., 2010, Separation of net ecosystem exchange into assimilation and respiration using a light response curve approach - critical issues and global evaluation: Global Change Biology, v. 16, p. 187-208, available at http://dx.doi.org/10.1111/j.1365-2486.2009.02041.x.

Litton, C.M., Sandquist, D.R., and Cordell, S., 2006, Effects of non-native grass invasion on aboveground carbon pools and tree population structure in a tropical dry forest of Hawaii: Forest Ecology and Management, v. 231, no. 1-3, p. 105-113, available at http://dx.doi.org/10.1016/j.foreco.2006.05.008.

Mokany, Karel, Raison, R.J., and Prokushkin, A.S., 2006, Critical analysis of root : shoot ratios in terrestrial biomes: Global Change Biology, v. 12, no. 1, p. 84-96.

Moreno, Á., García-Haro, F.J., Martínez, B., and Gilabert, M.A., 2014, Noise reduction and gap filling of fAPAR time series using an adapted local regression filter: Remote Sensing, v. 6, no. 9, p. 8238-8260, available at http://dx.doi.org/10.3390/ rs6098238.

Neto, A.G., K.F. Gobbi, and, J. Silva, 2012, Tillering and biomass partitioning of Mombasa grass under nitrogen fertilization during regrowth: Revista Brasileira de Zootecnia, v. 41, no. 8, 1824-1831, available at http://dx.doi.org/10.1590/S151635982012000800004 .

Running, S.W., Nemani, R.R., Heinsch, F.A., Zhao, M., Reeves, M., and Hashimoto, H., 2004, A continuous satellite-derived measure of global terrestrial primary production: BioScience, v. 54, no. 6 , p. 547-560.

Schuur, E.A.G., Chadwick, O.A., and Matson, P.A., 2001, Carbon cycling and soil carbon storage in mesic to wet Hawaiian montane forests: Ecology, v. 82, no. 11, p. 3182-3196. 
Schuur, E.A.G., and Matson, P.A., 2001, Net primary productivity and nutrient cycling across a mesic to wet precipitation gradient in Hawaiian montane forest: Oecologia, v. 128, no. 3, p. 431442, available at http://dx.doi.org/10.1007/s004420100671.

Selmants, P.C., Litton, C.M., Giardina, C.P., and Asner, G.P., 2014, Ecosystem carbon storage does not vary with mean annual temperature in Hawaiian tropical montane wet forests: Global Change Biology, v. 20, no. 9, p. 2927-2937, available at http:// dx.doi.org/10.1111/gcb.12636.

Soil Survey Staff, 2015, Gridded Soil Survey Geographic (gSSURGO) Database for Hawaii: United States Department of Agriculture, Natural Resources Conservation Service, accessed August 21, 2015 at https://gdg.sc.egov.usda.gov/ (FY2016 official release).

Torn, M.S., Trumbore, S.E., Chadwick, O.A., Vitousek, P.M., and Hendricks, D.M., 1997, Mineral control of soil organic carbon storage and turnover: Nature, v. 389, p. 170-173.

Townsend, A.R., Vitousek, P.M., and Trumbore, S.E., 1995, Soil organic matter dynamics along gradients in temperature and land use on the Island of Hawaii: Ecology, v. 76, no. 3, p. 721-733.

Williams, D.G., and Baruch, Z., 2000, African grass invasion in the Americas - ecosystem consequences and the role of ecophysiology: Biological Invasions, v. 2, no. 2, p. 123-140.
Williams, D.G., and Black, R.A., 1994, Drought response of a native and introduced Hawaiian grass. Oecologia, v. 97, no. 4 , p. 512-519.

Wolf, S., Eugster, W., Potvin, C., Turner, B.L., and Buchmann, N., 2011, Carbon sequestration potential of tropical pasture compared with afforestation in Panama: Global Change Biology, v. 17, no. 9, p. 2763-2780, available at http://dx.doi.org/10.1111/ j.1365-2486.2011.02460.x.

Yuan, W., Luo, Y., Li, X., Liu, S., Yu, G., Zhou, T., Bahn, M., Black, A., Desai, A.R., Cescatti, A., Marcolla, B., Jacobs, C., Chen, J., Aurela, M., Bernhofer, C., Gielen, B., Bohrer, G., Cook, D.R., Dragoni, D., Dunn, A.L., Gianelle, D., Grünwald, T., Ibrom, A., Leclerc, M.Y., Lindroth, A., Liu, H., Marchesini, L.B., Montagnani, L., Pita, G., Rodeghiero, M., Rodrigues, A., Starr, G., Stoy, P.C., 2011, Redefinition and global estimation of basal ecosystem respiration rate: Global Biogeochemical Cycles, v. 25, no. 4,14 p., available at http://dx.doi. org/10.1029/2011GB004150.

Zhao, M., Heinsch, F.A., Nemani, R.R., and Running, S.W., 2005, Improvements of the MODIS terrestrial gross and net primary production global data set. Remote Sensing of Environment, v. 95, p. 164-176. 



\title{
Chapter 7. Baseline and Projected Future Aquatic Carbon Fluxes to Nearshore Waters in Hawai'i
}

\author{
By Richard A. MacKenzie, ${ }^{1}$ Ayron M. Strauch, ${ }^{2}$ Tracy N. Wiegner, ${ }^{3}$ Steven L. Colbert, ${ }^{3}$ Edward G. Stets,,${ }^{4}$ and \\ Robert G. Streigl ${ }^{3}$
}

\subsection{Highlights}

- Total carbon flux to nearshore waters from perennial streams and submarine groundwater discharge (SGD) from five of the seven main Hawaiian Islands was estimated to be $0.309 \mathrm{TgC} / \mathrm{yr}$. This total was dominated by SGD inputs ( 74 percent or $0.228 \mathrm{TgC} / \mathrm{yr}$ ), which were largely composed of dissolved inorganic carbon (DIC). Dominance by DIC in the total flux was partially the result of a lack of dissolved organic carbon (DOC) datasets and the general absence of particulate organic carbon (POC) from groundwater. SGD fluxes were greatest from Hawai'i Island $(0.146 \mathrm{TgC} / \mathrm{yr})$, representing more than half of the total SGD DIC inputs, followed by Maui ( 0.032 $\mathrm{TgC} / \mathrm{yr}), \mathrm{O}^{\prime} \mathrm{ahu}$ (0.024 TgC/yr), Kaua'i (0.023 TgC/yr), and Moloka'i ( $0.004 \mathrm{TgC} / \mathrm{yr})$. Perennial stream fluxes were greatest from $\mathrm{O}^{\prime} \mathrm{ahu}(0.023 \pm 0.008 \mathrm{TgC} / \mathrm{yr})$, followed by Kaua' $\mathrm{i}(0.020 \pm 0.005 \mathrm{TgC} / \mathrm{yr})$, Hawai' $\mathrm{i}(0.020 \pm 0.011$ $\mathrm{TgC} / \mathrm{yr})$, Maui $(0.014 \pm 0.008 \mathrm{TgC} / \mathrm{yr})$, and Moloka ${ }^{\prime} \mathrm{i}$ $(0.004 \pm 0.003 \mathrm{TgC} / \mathrm{yr})$.

- Total organic carbon (TOC), the combination of DOC and POC, represented 76.6 percent of carbon entering nearshore waters $(0.062 \pm 0.028 \mathrm{TgC} / \mathrm{yr})$ and ranged from 72.6 to 78.3 percent of total surface fluxes (0.003-0.016 TgC/yr) across the five of the seven main islands. DIC entering nearshore waters from perennial streams was estimated to be $0.019 \pm 0.006 \mathrm{TgC} / \mathrm{yr}$. Lack of data precluded estimating carbon burial in stream systems of Hawai'i. However, the "flashy" nature of these streams may limit carbon deposition, suggesting carbon burial is a small fraction in the overall aquatic carbon budget.

- Total carbon aquatic yields from perennial streams were greatest from $\mathrm{O}^{`}$ ahu $\left(20.36 \pm 6.73 \mathrm{gC} / \mathrm{m}^{2} / \mathrm{yr}\right)$,

\footnotetext{
${ }^{1}$ U.S. Department of Agriculture Forest Service.

${ }^{2}$ Hawai'i Dept. of Land and Natural Resources.

${ }^{3}$ University of Hawaii at Hilo.

${ }^{4}$ U.S. Geological Survey.
}

followed by Kaua'i $\left(16.63 \pm 4.45 \mathrm{gC} / \mathrm{m}^{2} / \mathrm{yr}\right)$, Maui (16.41 $\pm 9.75 \mathrm{gC} / \mathrm{m}^{2} / \mathrm{yr}$ ), Moloka'i (10.04 $\pm 7.16 \mathrm{gC} / \mathrm{m}^{2} /$ $\mathrm{yr})$, and Hawai'i Island $\left(8.18 \pm 4.30 \mathrm{gC} / \mathrm{m}^{2} / \mathrm{yr}\right)$. Again, TOC was the dominant form of carbon in carbon yields, representing 72.6-78.3 percent of aquatic carbon yields $\left(10.26 \pm 4.6 \mathrm{gC} / \mathrm{m}^{2} / \mathrm{yr}\right)$ across five of the main islands.

- Future increases in rainfall (0.3-39.5 percent) along wetter coasts of the Hawaiian Islands are expected to increase perennial stream TOC fluxes by nearly 10.6 percent and DIC fluxes by 8.1 percent. This would increase total surface aquatic fluxes to $0.089 \pm 0.036 \mathrm{TgC} / \mathrm{yr}$. SGD DIC inputs will would increase by 22.3 percent, increasing SGD fluxes to $0.279 \mathrm{TgC} / \mathrm{yr}$ (from $0.228 \mathrm{TgC} / \mathrm{yr}$ ).

\subsection{Introduction}

Pacific high islands of volcanic origin comprise watersheds with unique geomorphological, hydrological, and biological features compared to continental watersheds. Leeward and windward coasts are typically separated by high mountain ranges and consist of spatially compact, steeply sloped watersheds with relatively simple drainage networks and low-order streams (Resh and deSzalay, 1995). Because of their characteristics, stream systems on Pacific islands respond rapidly to short pulses of intense rain events that result from moisture laden airmasses moving off of the ocean and rising up along warm, high, volcanic island landmasses until they reach their dew point. Windward coasts are strongly influenced by trade winds and are characterized by perennial streams, whereas leeward coasts are isolated from trade winds by mountains and are characterized by intermittent streams. The spates or "freshettes" in windward perennial streams scour stream bottoms and deliver terrestrial-derived organic matter to nearshore waters.

The remote nature of Pacific islands has resulted in unique assemblages of endemic fauna as well as the absence of key species found in continental streams (Bright, 1982; Polhemus and others, 2000). Pacific-island streams generally lack native leafshredding organisms (such as stoneflies or caddisflies) (Larned, 
2000; Benstead and others, 2009; MacKenzie and others, 2013) and support lower levels of aquatic fungal biomass (MacKenzie and others, 2013) that are commonly found in continental streams and play an important role in leaf-litter breakdown and thus the carbon cycle (Vannote and others, 1980; Webster and Benfield, 1986). As a result, leaf-litter breakdown is much slower and is limited to fungal and microbial activity as well as physical abrasion (MacKenzie and others, 2013) resulting in a high export of coarse particulate organic carbon, especially during storm flows (Larned, 2000; Wiegner and others, 2009). Despite the lack of shredding insects, dissolved organic carbon (DOC) is still an important component of Pacific-island streams (Wiegner and others, 2009; Wiegner and Tubal, 2010) and nearshore waters (Atwood and others, 2012; Johnson and Wiegner, 2014). Modeled DOC fluxes from Pacific high islands in the Oceania region were equal to DOC fluxes to coastal zones in North America and Africa, with the per-area rate of DOC flux being greater in Oceania than anywhere in the world (Harrison and others, 2005).

Despite these modeled results, few studies have attempted to build carbon budgets from Pacific high islands; most studies have focused on POC and DOC fluxes from the Hawaiian Islands (Ringuet and MacKenzie, 2005; Mead and Wiegner, 2010; Wiegner and Tubal, 2010; Johnson and Wiegner, 2014). Baseline information on carbon budgets from high-island streams and groundwater and the factors that influence those budgets are paramount as human populations are expected to significantly increase in this area of the world over the next 25 years (Laws and Ferentinos, 2003) and climate and precipitation patterns are expected to change (Chu and Chen, 2005; Timm and others, 2011). Furthermore, flux of terrestrial-derived carbon to nearshore waters supports high levels of nearshore plankton and microbial production (Ringuet and MacKenzie, 2005; Wiegner and others, 2009; Mead and Wiegner, 2010; Johnson and Wiegner, 2014) that are fed on by many species of culturally and ecological important fin and shellfish (Atwood and others, 2012).

This chapter reports results from a first attempt to estimate carbon fluxes and yields from surface- and groundwater sources to nearshore waters around the seven main Hawaiian Islands: Hawai' $i$, Moloka 'i, Lāna'i, Kaho'olawe, Maui, O'ahu, and Kaua'i. The steeply sloped and "flashy" nature of these and other Pacific-island stream systems has resulted in the development of few lakes and ponds. Furthermore, carbon and streamflow data from surface water were largely restricted to perennial streams and rivers. Therefore, our surface water model only focuses on carbon fluxes from perennial streams. Lentic systems could potentially play an important role in the overall carbon cycle of Pacific islands (Stackpoole and others, 2012) and additional information is needed from these ecosystems. However, when combined with reservoirs, lentic systems represent less than 0.03 percent of the landmass in Hawai' $i$. Additional information on flow and carbon dynamics of intermittent streams is also needed as these ecosystems are often overlooked and can contribute significantly to overall stream function (Datry and others, 2014; Strauch and others,
2014). Finally, river $\mathrm{CO}_{2}$ emissions were also not included in this assessment. Additional data are needed to quantify this important component of the aquatic carbon cycle in Hawai' $i$. The objectives of this chapter are to (1) estimate coastal export of dissolved inorganic and total organic carbon from perennial streams and submarine groundwater discharge (SGD), (2) compare carbon export values across the seven main Hawaiian Islands and evaluate inter-island variability, and (3) provide a preliminary examination of how the onset of climate change would impact carbon export to coastal waters.

\subsection{Input Data and Methods}

\subsubsection{Surface Water Carbon Inputs to Nearshore Ecosystems}

Carbon fluxes to nearshore areas were limited to watersheds with perennial streams on five of the seven main Hawaiian Islands; neither Lāna'i nor Kaho 'olawe have any perennial streams. Carbon fluxes were first modeled from 16 perennial streams that had long-term discharge and carbon datasets from the U.S. Geological Survey (USGS) National Water Information Service (NWIS) (USGS, 2012). Dissolved inorganic carbon (DIC) concentrations (in micromoles) were estimated from USGS NWIS measurements of $\mathrm{pH}$, temperature, and either filtered or unfiltered alkalinity (Stets and Striegl, 2012). Total organic carbon (TOC) concentrations (in milligrams per liter) were either direct measurements or the sum of dissolved and particulate organic carbon. Daily DIC and TOC fluxes were then determined for those 16 streams using the USGS Load Estimator Model (LOADEST) (Runkel and others, 2004). LOADEST is a multiple-regression Adjusted Maximum Likelihood Estimation (AMLE) model which uses measured DIC or TOC concentration values to calibrate a regression among constituent load, streamflow, season, and time by the following equation:

$$
\begin{aligned}
& \ln L O A D=\mathrm{a}_{0}+\mathrm{a}_{1} \ln Q+\mathrm{a}_{2} \ln Q^{2}+\mathrm{a}_{3} \sin (2 \pi \text { dtime }) \\
& +\mathrm{a}_{4} \cos (2 \pi \text { dtime })+\mathrm{a}_{5} \text { dtime }+\mathrm{a}_{6} \mathrm{dtime} \mathrm{e}^{2}+\varepsilon
\end{aligned}
$$

where

$$
\begin{aligned}
& \ln L O A D \begin{array}{r}
\text { is the natural log of the DIC or TOC } \\
\text { constituent load (mol/d or } \mathrm{kg} / \mathrm{d}, \\
\text { respectively), }
\end{array} \\
& Q \quad \begin{array}{l}
\text { is the discharge, } \\
\text { is time in decimal years, }
\end{array} \\
& \mathrm{a}_{0}, \mathrm{a}_{1} \ldots \mathrm{a}_{\mathrm{n}} \begin{array}{l}
\text { are regression coefficients, and } \\
\mathcal{E}
\end{array} \quad \begin{array}{l}
\text { is an independent and normally distributed } \\
\text { error. }
\end{array}
\end{aligned}
$$

Model calibration required at least 12 paired water-quality (for example, DIC, TOC) and daily streamflow measurements over at least a 3-year period from 1972 to 2013 . We chose 1972 as the starting time point because a long-term streamflow analysis revealed no significant change in streamflow since that time (Bassiouni 
and Oki, 2012). Once the model was calibrated for each of the 16 streams, LOADEST was then used to estimate daily carbon flux for those streams using continuous flow data during the time range of carbon measurements. Input data were log-transformed to avoid bias and centered to avoid multicollinearity. The models used to estimate loads for individual USGS stations varied in terms of coefficients and estimates of log load (equation 1). LOADEST output complications, including retransformation bias, data censoring, and non-normality were reduced using (AMLE) and the highest value for Schwarz Posterior Probability Criterion (SPCC). The estimated loads and their standard errors were used to develop 95-percent confidence intervals for various periods. The model's performance was examined by reviewing its output, such as the partial load factor (PLF), Nash-Sutcliffe Efficiency (NSE) coefficient (Stenback and others, 2011), and AMLE's coefficient of determination $\left(R^{2}\right)$ values and residuals (model error). PLF ranges from -1 to 1; model values below zero were rejected owing to over prediction. NSE ranges from $-\infty$ to 1 with values above zero indicating model predictions more accurate than the mean of the observed data. Mean daily DIC and TOC loads were then estimated for each of the 16 streams using the best of nine models based on Akaike's Information Criterion (Runkel and others, 2004). Daily values were then summed up for each year and averaged across years.

Average annual TOC and DIC fluxes for each of these 16 watersheds were then correlated to various characteristics of watersheds above each USGS streamgage in Sigma Plot. Independent variables included drainage area (in square miles), mean basin slope (in percent), area-weighted mean soil permeability (top 12 inches; in inches per hour), percent barren land, percent evergreen forest, percent cultivated crop, percent impervious area, percent urban land cover, mean annual precipitation (in inches), and $\mathrm{Q}_{50}$ (in cubic feet per second). All but $\mathrm{Q}_{50}$ were obtained from STREAMSTATS program using geospatial data made available by the USGS (Rea and Skinner, 2012). $Q_{50}$ was the median streamflow in each stream and was averaged across the water years from which DIC and TOC measurements were obtained. We looked at all possible linear combinations among $\log$ TOC and $\log$ DIC and all possible combinations of 1,2 , and 3 of the 9 predictors listed above. We took this approach because the sample size $(n=16)$ was too small to warrant more than three predictors in a single model. We then chose the model with the lowest Akaike Information Criterion (AIC) score and highest AIC weight to estimate TOC and DIC loads (fig. 7.1) from the remaining 401 ungaged and short-term gaged perennial streams. $Q_{50}$ estimates for these 401 perennial streams were estimated using the formula developed by Fontaine and others (1992):

$$
\mathrm{Q}_{50}=4.49 \times D A^{0.808} \times C E^{-0.641} \times P^{0.985}
$$

where $D A$ is drainage area,

$C E \quad$ is mean channel elevation from 10 and 85 percent of channel length, and

$P \quad$ is mean annual precipitation.

Individual watershed annual TOC and DIC fluxes were then converted to teragrams of carbon per year and summed by island. Yields (in grams of carbon per square meter per year) were estimated by dividing fluxes by the sum of the watershed area for each island. Total carbon fluxes were then calculated as the sum of TOC and DIC fluxes across five of the main Hawaiian Islands; total carbon yields were the sum of the carbon fluxes divided by the watershed area for each catchment. Standard errors were determined for TOC and DIC fluxes and yields from each watershed using the applied delta method and variances and covariance from the coefficients in figure 7.1 (Bishop and others, 1975). The square root of the sum of these errors squared was then used to determine the standard errors for each island and across Hawai' $i$.

Tropical island streams differ from temperate continental streams in several ways (see Resh and deSzalay, 1995) and models developed for temperate watersheds (for example, the Universal Soil Loss Equation) do not always function similarly in tropical ones (Millward and Mersey, 1999; Prasannakumar and others, 2012). Therefore, to determine the accuracy of LOADEST predicted carbon loads from Hawaiian streams, we compared LOADEST model output of particulate carbon (PC) to actual continuous measurements of $\mathrm{PC}$ from three watersheds along the north Hilo coast of Hawai'i Island. Sub-daily (15-minuteinterval) measurements of turbidity (Strauch and others, 2014) and streamflow (Strauch and others, 2015) were used to estimate total suspended sediment (TSS) fluxes for the 2013 calendar year. TSS fluxes were then converted to PC by using grab samples collected across a range of streamflows, analyzed for PC, and then calibrated to the TSS values. PC was then estimated by summing values (in milligrams of carbon per second) for each watershed for the whole year. PC measurements were also used to calibrate the LOADEST Fortran model. Actual observed PC fluxes were then compared to LOADEST estimates.

\subsubsection{Groundwater Inputs to Nearshore Ecosystems}

Aquifers in Hawai' $i$ have been delineated into a series of "hydrologic units" based on surface geology, such as topographic divides, and subsurface geology, such as rift zones (Mink and Lau, 1990, 1992, 1993). Each hydrologic unit typically includes several watersheds within a similar geologic and climatic setting. Within each hydrologic unit, the groundwater flux of TOC and DIC to the ocean was calculated as follows:

$$
G W f l u x=Q \times C
$$

where $\quad Q \quad$ is the submarine groundwater discharge (SGD) and

$C$ is the concentration of TOC or DIC in groundwater.

The TOC and DIC fluxes from groundwater were computed using available data from the USGS (http://nwis.waterdata.usgs.gov/ usanwis/qwdata). The methods for compiling data and data sources are further described below. 


\subsubsection{Submarine Groundwater Discharge Data}

Hydrologic budgets have been used widely to estimate groundwater recharge of each hydrologic unit on the seven largest islands in Hawai'i (Shade, 1995, 1997, 1999; Shade and Nichols, 1996; Engott and Vana, 2007; Engott, 2011). Ultimately, this groundwater recharge flows back to the ocean, and can be used as an estimate of fresh submarine groundwater discharge. Because most of these models do not account for baseflow groundwater discharge to rivers and streams, this estimate of recharge is an upper limit. For hydrologic units not in direct contact with the sea, the recharge was treated as an underflow and added to an adjacent aquifer unit. For Kaho'olawe, groundwater recharge was estimated based on the average rainfall and the recharge to rainfall ratio of 21 percent calculated for hydrologic units on the leeward side of east Maui (Shade, 1999).

\subsubsection{Chemical Data}

Well data for $\mathrm{pH}$ and alkalinity were summarized from the USGS (2014). To maximize the available data for this analysis, alkalinity data measured using both fixed endpoint and inflection point titration data of filtered and unfiltered samples, measured either in the field or the lab, were used (399 alkalinity measurements from 269 wells). Of these wells, 17 were not used because they had a specific conductivity greater than 5 microsiemens per centimeter $(\mathrm{mS} / \mathrm{cm})$ and were likely impacted by high alkalinity seawater or a temperature greater than $35^{\circ} \mathrm{C}$ and geothermally altered. Of the remaining measurements, 94 percent were from less than $7 \mathrm{~km}$ in from the shoreline, providing a reasonable estimate of the alkalinity for basal groundwater flowing into the ocean. Measurements more than $7 \mathrm{~km}$ from the shoreline were only made on $\mathrm{O}^{\prime}$ ahu and Hawai' $i$ Island. Alkalinity reported in milligrams of $\mathrm{CaCO}_{3}$ per liter was converted to milliequivalents per liter (meq/L) by multiplying by 0.01998 (Rounds, 2006) before calculating total $\mathrm{CO}_{2}\left(\mathrm{TCO}_{2}\right)$ or DIC. For $\mathrm{pH}$, only field measurements of unfiltered water were used $(481 \mathrm{pH}$ measurements from 283 wells), because repeated measurements in the lab were $0.42 \pm 0.41 \mathrm{pH}$ units greater than field measurements, suggesting $\mathrm{CO}_{2}$ degassing during transport $(\mathrm{n}=301)$. For each well, the average alkalinity, $\mathrm{pH}$, and temperature were computed. For wells with alkalinity data but no $\mathrm{pH}$ data, $\mathrm{pH}$ data from nearby wells within the same hydrologic system were used $(n=35)$. Of these, half of the $\mathrm{pH}$ measurements were from wells within $5 \mathrm{~km}$ of the corresponding alkalinity measurements. DIC for the 234 wells was calculated using the USGS $\mathrm{CO}_{2}$ Calc software, using $\mathrm{K} 1$ and $\mathrm{K} 2$ from Millero (1979), the $\mathrm{pH}$ NBS scale, an average $\mathrm{SiO}_{2}$ of $790 \mu \mathrm{M}$, and a water density of $0.998 \mathrm{~g} / \mathrm{cm}^{3}$ (Robbins and others, 2010).

For each hydrologic system, the mean $( \pm 1 \mathrm{SD})$ concentration was computed. For systems lacking measurements, the average DIC concentration of adjacent hydrologic units was applied. No data were available for Kaho'olawe and Lāna'i, so the average DIC for Maui and the average DIC for West Maui and Moloka' $i$ were applied, respectively. Uncertainty could not be estimated for
DIC SGD estimates, either by island or across Hawai' $i$, owing to lack of data.

All DOC data were from the USGS $(n=58)$ (USGS, 2014), and were filtered water samples except three unfiltered samples from well 3-1851-22 on Ala Moana Boulevard in Honolulu, O‘ahu. For samples below the detection limit $(n=39)$, a nominal concentration of one-half of the detection limit was applied.

\subsubsection{Total Carbon Fluxes and Yields}

Total carbon fluxes (in teragrams of carbon per year) were then estimated by adding the stream total carbon fluxes (TOC and DIC) and the DIC SGD fluxes. Total carbon yields (in grams of carbon per square meter per year) were estimated by dividing the total carbon fluxes by the total area of five of the main Hawaiian Islands (Hawai'i, Kaua'i, Moloka'i, Maui, and O'ahu). Uncertainty could not be estimated for total carbon fluxes because of the lack of uncertainty from SGD estimates.

\subsubsection{Future Impacts on Carbon Inputs to Nearshore waters}

Impacts of climate change on perennial stream and SGD carbon fluxes were examined by calculating the projected change in mean annual precipitation (MAP) for each respective watershed. Changes in MAP between current (annual average of 1990-2010) and end-of-century (annual average of 2080-2100) scenarios were calculated from the Hawaiian Regional Climate Model (HRCM) with 3-km spatial resolution (Zhang and others, 2012).

The HRCM is based on the Weather Research and Forecasting model ver. 3.3. It considers future climate forcing based on the SRES A1B emission scenario and the mean of multiple CMIP3 global circulation models. The HRCM simulations replicate the regional and island climate mechanisms that largely dictate local climate such as extreme orographic-based precipitation gradients and trade wind inversions (Zhang and others, 2012). As such, the computing requirements to run the HRCM simulations limit our analyses to a single future climate scenario. However, preliminary results showed that interpolated global circulation model (GCM) projections, such as those commonly used in continental species distribution model analyses, are of very limited value for a small, hyper-diverse climatic region such as Hawai'i.

Changes in mean annual rainfall from each hydrologic unit described above were used to estimate changes in SGD based on the mean annual rainfall-to-recharge ratio of the hydrologic unit. The mean annual rainfall-to-recharge ratio also changes with variations in precipitation. To estimate the changes in the mean annual rainfall to recharge ratio, the modeling results for changes in recharge in different rainfall conditions on Hawai' $i$ Island were examined (Engott, 2011). Based on these modeled scenarios, a linear relationship between the fractional change in precipitation and the change in recharge to mean annual rainfall ratio was identified and applied to all islands: 


$$
\text { Fppt }=(\text { Pcurrent }- \text { Pfuture }) / \text { Pcurrent }
$$

$$
\Delta \mathrm{R}=\mathrm{Rcurrent}-\mathrm{R} \text { future }
$$

where

Fppt is fractional change in precipitation,

Pcurrent is current precipitation, Pfuture is precipitation at the end of the century (2100),

$\Delta \mathrm{R}$ is change in recharge,

Rcurrent is current recharge, and

Rfuture is recharge at the end of the century (2100).

The relationship for increasing mean annual rainfall $(\Delta \mathrm{R}=0.256 \times \mathrm{Fppt} ; \mathrm{R} 2=0.93)$ differed from the decreasing mean annual rainfall relationship $(\Delta \mathrm{R}=0.34 \mathrm{Fppt} ; \mathrm{R} 2=0.78)$ owing to different hydrologic processes occurring (for example, transpiration, vadose zone transport). For perennial streams, changes in mean annual rainfall to each perennial watershed were determined by multiplying the current mean annual rainfall by the predicted percent change. Future mean rainfall values were then used to model $\mathrm{Q}_{50}$ for each perennial stream following the equation in Fontaine (1992), which was then used to predict TOC and DIC using the methods described above.

\subsection{Results}

\subsubsection{LOADEST Model Calibration}

Of the 16 stream datasets used to calibrate LOADEST, 10 included the years 1975-1981. Six stream datasets had calibration and flow data from the 2000s and 2 were calibrated exclusively after 1999. Thus the range years of all included data in the model runs was from 1972 to 2012. Although three stations had less than 5 years of data that met our guidelines, the mean number of years used was 10.8. When LOADEST output was correlated to the various watershed parameters, only $\mathrm{Q}_{50}$ proved to be a significant predictor of carbon load (fig. 7.1).

\subsubsection{Lateral Carbon Transport in Riverine Systems}

Based on the Division of Aquatic Resources (DAR) Hawaiian watershed atlas, there were a total of 417 perennial streams on the five main Hawaiian Islands (fig. 7.2; table 7.1). Hawai' $i$ Island had the greatest number of perennial streams (fig. 7.2; table 7.1), with 30 percent more perennial streams

Table 7.1. Summary of available surface water data for the State of Hawai'i.

[Area of watersheds includes only those watersheds where estimates could be made. TOC, total organic carbon; DIC, dissolved inorganic carbon]

\begin{tabular}{lcccccc}
\hline Island & Area $\left(\mathbf{k m}^{2}\right)$ & $\begin{array}{c}\text { Number of } \\
\text { perennial Streams }\end{array}$ & $\begin{array}{c}\text { Area of perennial } \\
\text { watersheds }\left(\mathbf{k m}^{2}\right)\end{array}$ & $\begin{array}{c}\text { Number of USGS } \\
\text { gage sites used }\end{array}$ & $\begin{array}{c}\text { Number of distinctly } \\
\text { gaged watersheds }\end{array}$ & $\begin{array}{c}\text { Number of TOC/ } \\
\text { DIC sites }\end{array}$ \\
\hline Hawai'i & 10,432 & 126 & 2,457 & 6 & 5 & 3 \\
Kaua'i & 1,430 & 77 & 1,215 & 11 & 8 & 1 \\
Moloka'i & 637 & 58 & 431 & 1 & 1 & 1 \\
Maui & 1,884 & 92 & 824 & 9 & 9 & 1 \\
O'ahu & 1,545 & 64 & 1,121 & 22 & 17 & 10 \\
Total & 15,928 & 417 & 6,048 & 49 & 40 & 16 \\
\hline
\end{tabular}
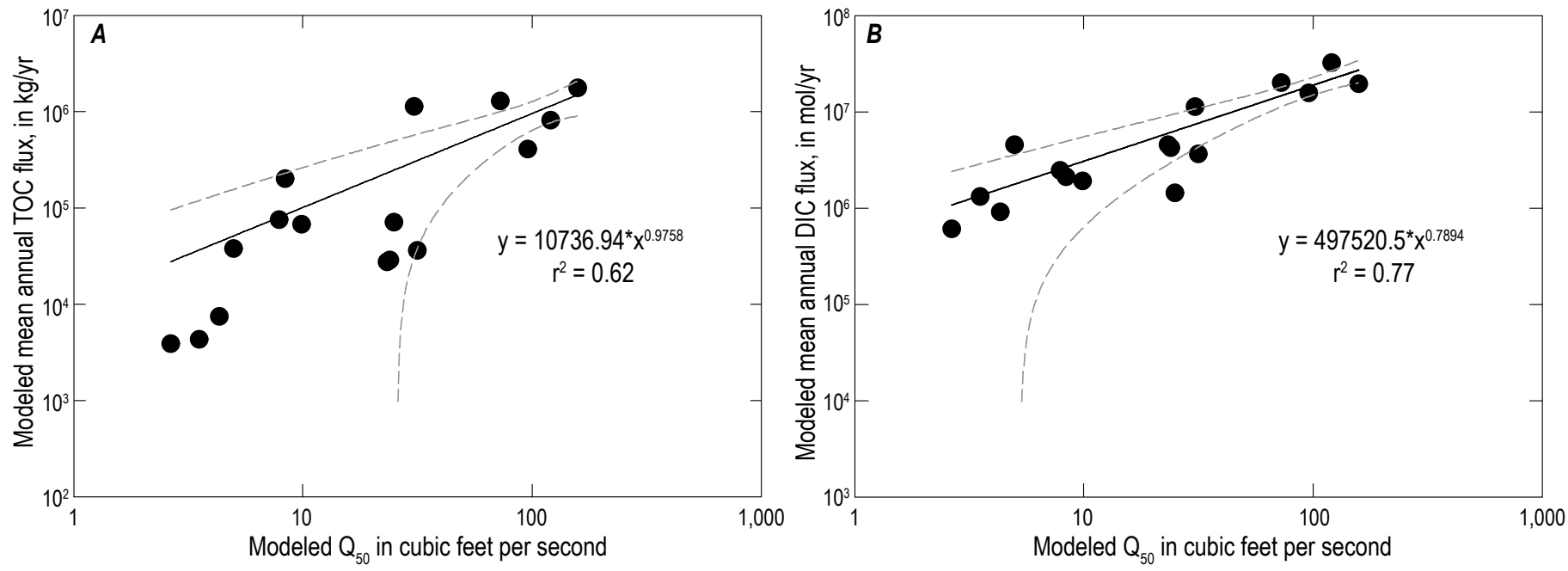

Figure 7.1. Plots of relationship between modeled median streamflow $\left(Q_{50}\right)$ and modeled mean annual total organic carbon (TOC) $(A)$ and dissolved inorganic carbon (DIC) $(B)$ for watersheds across the State of Hawaiti. kg/yr, kilograms per year; mol/yr, moles per year. 


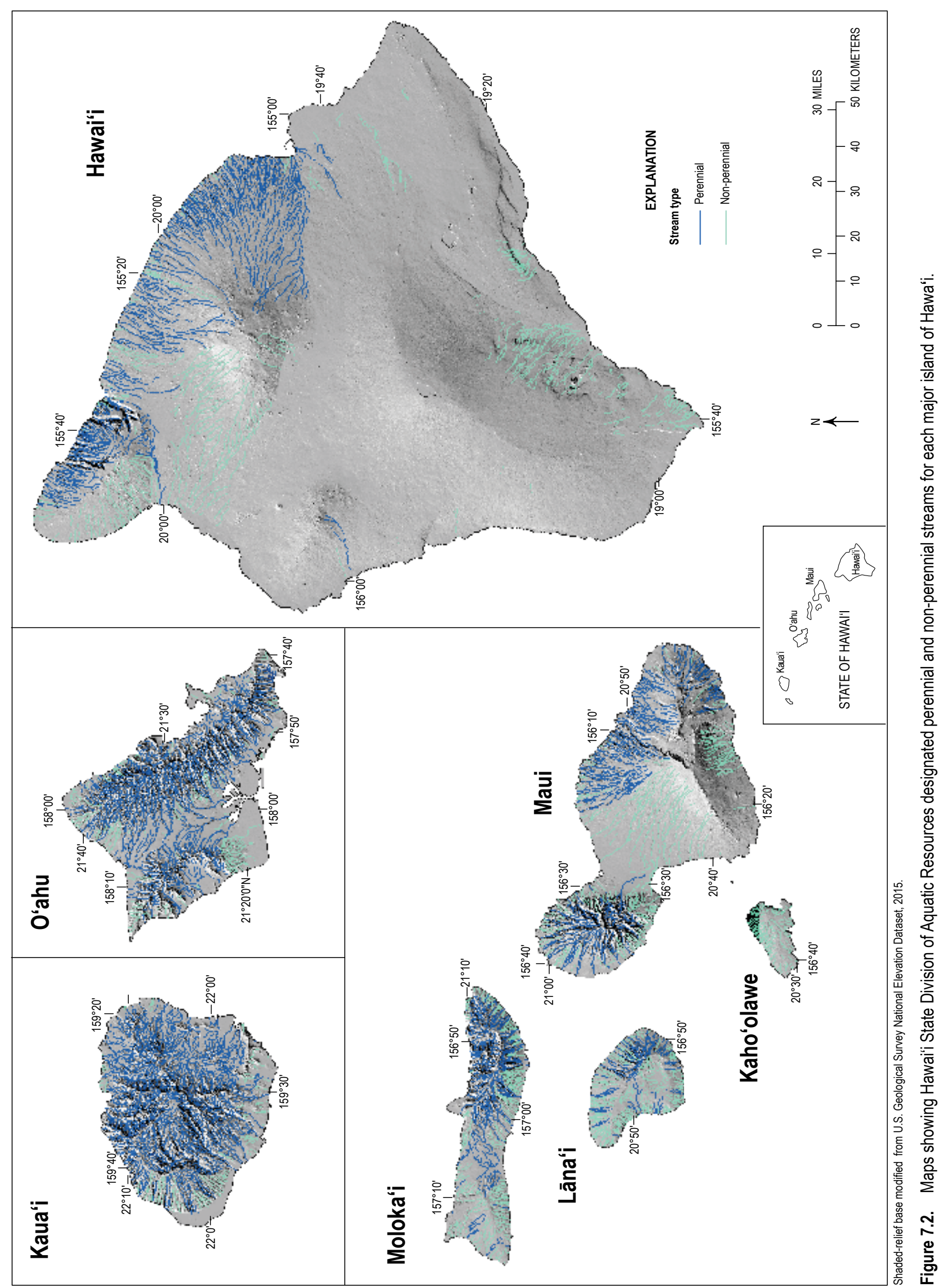


than the other Hawaiian Islands in this assessment. Only 38 percent of the area of the five main islands was represented by watersheds with perennial streams, owing to vast leeward areas of the largest two islands (Hawai' $i$ [76 percent] and Maui [56 percent]) lacking any perennial streams. By contrast, 85 percent of Kaua' $i$, 73 percent of $\mathrm{O}^{`}$ ahu, and 68 percent of Moloka'i were represented by perennial-stream watersheds.

LOADEST-modeled TOC and DIC values were highly variable among streams in Hawai'i. Kaua'i Island has the highest average $( \pm 1 \mathrm{SE})$ modeled TOC fluxes $(1,298,000 \pm 466,000$ $\mathrm{kg} / \mathrm{yr})$, followed by Hawai'i $(1,247,000 \pm 222,000 \mathrm{~kg} / \mathrm{yr})$, Moloka'i (203,000 $\pm 26,000 \mathrm{~kg} / \mathrm{yr}), \mathrm{O}$ ‘ahu $(70,000 \pm 13,000$ $\mathrm{kg} / \mathrm{yr})$, and Maui $(68,000 \pm 11,000 \mathrm{~kg} / \mathrm{yr})$. Hawai'i Island had the highest average ( $\pm 1 \mathrm{SE})$ LOADEST-modeled DIC fluxes $(252,000 \pm 32,000 \mathrm{~kg} / \mathrm{yr})$, followed by Kaua'i $(240,000 \pm 52,000$ $\mathrm{kg} / \mathrm{yr})$, O‘ahu $(47,000 \pm 3,000 \mathrm{~kg} / \mathrm{yr})$, Moloka'i $(25,000 \pm 2,000$ $\mathrm{kg} / \mathrm{yr})$, and Maui $(23,000 \pm 2,000 \mathrm{~kg} / \mathrm{yr})$.

The total carbon flux from perennial Hawaiian streams was estimated to be $0.080 \pm 0.033 \mathrm{TgC} / \mathrm{yr}$ (table 7.2). The amount of carbon exported to Hawai'i's nearshore waters was greatest from O'ahu $(0.023 \pm 0.008 \mathrm{TgC} / \mathrm{yr})$, followed by Kaua'i $(0.020 \pm 0.005$ TgC/yr), Hawai'i ( $0.020 \pm 0.011 \mathrm{TgC} / \mathrm{yr})$, Maui $(0.014 \pm 0.008$ $\mathrm{TgC} / \mathrm{yr})$, and Moloka' $i(0.004 \pm 0.003 \mathrm{TgC} / \mathrm{yr})$. TOC fluxes were higher than DIC fluxes from streams on all five islands, with TOC fluxes representing nearly 76.6 percent of the total stream carbon entering Hawaiian nearshore waters. DIC fluxes were nearly half that of TOC fluxes and were greatest from Hawai' $i$ Island $(0.005$ $\mathrm{TgC} / \mathrm{yr})$ and $\mathrm{O}^{\prime}$ ahu $(0.005 \pm 0.001 \mathrm{TgC} / \mathrm{yr})$, followed by Kaua' $\mathrm{i}$ $(0.004 \pm 0.001 \mathrm{TgC} / \mathrm{yr})$, Maui $(0.003 \pm 0.001 \mathrm{TgC} / \mathrm{yr})$, and Moloka'i $(0.001 \pm 0.001 \mathrm{TgC} / \mathrm{yr})$.

When area of watersheds was used to normalize stream carbon fluxes, contributions from the different islands were somewhat similar. Total carbon aquatic yields from perennial streams were greatest from $\mathrm{O}^{\prime} \mathrm{ahu}\left(20.36 \pm 6.73 \mathrm{gC} / \mathrm{m}^{2} / \mathrm{yr}\right)$, followed by Kaua'i $\left(16.63 \pm 4.45 \mathrm{gC} / \mathrm{m}^{2} / \mathrm{yr}\right)$, Maui $(16.41 \pm 9.75$ $\left.\mathrm{gC} / \mathrm{m}^{2} / \mathrm{yr}\right)$, and Moloka'i (10.04 $\left.\pm 7.16 \mathrm{gC} / \mathrm{m}^{2} / \mathrm{yr}\right)$. Streams from Hawai' $i$ Island, the largest of the five islands, had the lowest carbon yield $\left(8.18 \pm 4.30 \mathrm{gC} / \mathrm{m}^{2} / \mathrm{yr}\right)$ owing to the larger area of perennial watersheds. Total modeled stream carbon yield from all islands was $13.39 \pm 5.68 \mathrm{gC} / \mathrm{m}^{2} / \mathrm{yr}$, with TOC yields being slightly greater than DIC yields and making up 72.6-78.3 percent of total carbon yields.

Comparison of LOADEST-modeled PC flux to observed fluxes revealed that LOADEST underestimated PC fluxes. LOADEST estimates ranged from 37,902 to $726,322 \mathrm{kgC} / \mathrm{yr}$, whereas observed values ranged from 155,391 to $1,225,825 \mathrm{kgC} / \mathrm{yr}$ (table 7.4). LOADEST values were 40.7-75.6 percent lower than observed values, with the level inaccuracy increasing with decreased mean annual rainfall, watershed area, and mean streamflow $\left(\mathrm{Q}_{50}\right)$.

\subsubsection{Carbon Fluxes from Submarine Groundwater Discharge}

DIC was calculated at 250 wells across Hawai' $i$, ranging from 3.3 to $81.5 \mathrm{mgC} / \mathrm{L}$ (fig. 7.3). Most samples fell within a relatively narrow range of $20.3 \pm 11.6 \mathrm{mgC} / \mathrm{L}$. DIC varied considerably on each island, with the highest values in areas likely with geothermal activity (Hawaii Institute of Geophysics, 1983). The median DIC in groundwater varied significantly among islands according to a Kruskal-Wallis nonparametric test $(\mathrm{H}=35$, $\mathrm{p}<0.001)$. Although the highest mean DIC was on Kaua' $i$, there was no obvious trend in DIC as a function of island age (table 7.5).

Table 7.2. Estimated baseline total organic carbon and dissolved inorganic carbon fluxes and yields $( \pm 1 \mathrm{SE})$ based on the $Q_{50}$ regression model.

[Total surface flux and yield from perennial riverine systems for each island and the entire State of Hawai'i are also presented. $\mathrm{Q}_{50}$ values (annual median streamflow over the sampling period) for each river were estimated using the equation from Fontaine and others (1992) and the mean annual precipitation, drainage areas, and mean channel elevations. Fluxes were normalized to entire or total island areas. TOC, total organic carbon; DIC, dissolved inorganic carbon; $\mathrm{m}^{3} / \mathrm{s}$, cubic meters per second; $\mathrm{TgC} / \mathrm{yr}$, teragrams of carbon per year; $\mathrm{gC} / \mathrm{m}^{2} / \mathrm{yr}$, grams of carbon per square meter per year]

\begin{tabular}{|c|c|c|c|c|c|c|c|c|c|}
\hline Island & $\begin{array}{l}\text { Number } \\
\text { of sites }\end{array}$ & $\begin{array}{c}\text { Mean annual } \\
\text { precipitation } \\
\text { (mm/yr) }\end{array}$ & $\begin{array}{c}\text { Mean } Q_{50} \\
\left(\mathrm{~m}^{3} / \mathrm{s}\right)\end{array}$ & $\begin{array}{c}\text { Estimated TOC } \\
\text { flux } \\
\text { (TgC/yr) }\end{array}$ & $\begin{array}{c}\text { Estimated TOC } \\
\text { yield } \\
\left(\mathrm{gC} / \mathrm{m}^{2} / \mathrm{yr}\right)\end{array}$ & $\begin{array}{c}\text { Estimated DIC } \\
\text { flux } \\
\text { (TgC/yr) }\end{array}$ & $\begin{array}{c}\text { Estimated DIC } \\
\text { yield } \\
\left(\mathrm{gC} / \mathrm{m}^{2} / \mathrm{yr}\right)\end{array}$ & $\begin{array}{l}\text { Estimated total } \\
\text { surface flux } \\
\text { (TgC/yr) }\end{array}$ & $\begin{array}{c}\text { Estimated total } \\
\text { surface yield } \\
\text { (gC/m²/yr) }\end{array}$ \\
\hline Hawai' $i$ & 123 & 3,130 & 0.34 & $\begin{array}{c}0.015 \\
(0.008)\end{array}$ & $\begin{array}{c}6.17 \\
(3.52)\end{array}$ & $\begin{array}{c}0.005 \\
(0.002)\end{array}$ & $\begin{array}{c}2.01 \\
(0.78)\end{array}$ & $\begin{array}{c}0.020 \\
(0.010)\end{array}$ & $\begin{array}{c}8.18 \\
(4.30)\end{array}$ \\
\hline Kaua'i & 75 & 2,030 & 0.75 & $\begin{array}{c}0.016 \\
(0.004)\end{array}$ & $\begin{array}{c}13.02 \\
(3.47)\end{array}$ & $\begin{array}{c}0.004 \\
(0.001)\end{array}$ & $\begin{array}{c}3.61 \\
(0.98)\end{array}$ & $\begin{array}{c}0.020 \\
(0.005)\end{array}$ & $\begin{array}{c}16.63 \\
(4.45)\end{array}$ \\
\hline Moloka'i & 58 & 1,428 & 0.15 & $\begin{array}{c}0.003 \\
(0.003)\end{array}$ & $\begin{array}{c}7.28 \\
(5.83)\end{array}$ & $\begin{array}{c}0.001 \\
(0.001)\end{array}$ & $\begin{array}{c}2.75 \\
(1.33)\end{array}$ & $\begin{array}{c}0.004 \\
(0.004)\end{array}$ & $\begin{array}{c}10.03 \\
(7.16)\end{array}$ \\
\hline Maui & 92 & 3,356 & 0.31 & $\begin{array}{c}0.010 \\
(0.007)\end{array}$ & $\begin{array}{c}12.23 \\
(8.03)\end{array}$ & $\begin{array}{c}0.003 \\
(0.001)\end{array}$ & $\begin{array}{c}4.18 \\
(1.72)\end{array}$ & $\begin{array}{c}0.013 \\
(0.008)\end{array}$ & $\begin{array}{c}16.41 \\
(9.75)\end{array}$ \\
\hline O‘ahu & 64 & 1,960 & 0.81 & $\begin{array}{c}0.018 \\
(0.006) \\
\end{array}$ & $\begin{array}{r}15.93 \\
(5.46) \\
\end{array}$ & $\begin{array}{c}0.005 \\
(0.001) \\
\end{array}$ & $\begin{array}{c}4.43 \\
(1.26) \\
\end{array}$ & $\begin{array}{c}0.023 \\
(0.007) \\
\end{array}$ & $\begin{array}{r}20.36 \\
(6.73) \\
\end{array}$ \\
\hline Total & 413 & & & $\begin{array}{c}0.062 \\
(0.028)\end{array}$ & $\begin{array}{c}10.26 \\
(4.60)\end{array}$ & $\begin{array}{c}0.019 \\
(0.006)\end{array}$ & $\begin{array}{c}3.13 \\
(1.07)\end{array}$ & $\begin{array}{c}0.080 \\
(0.033)\end{array}$ & $\begin{array}{c}13.39 \\
(5.68) \\
\end{array}$ \\
\hline
\end{tabular}


Table 7.3. Projected future total organic carbon and dissolved inorganic carbon fluxes and yields $( \pm 1 \mathrm{SE})$ based on the $Q_{50}$ regression model.

[Total surface flux and yield from perennial riverine systems for each island and the entire State of Hawai'i are also presented. $Q_{50}$ (annual median streamflow over the sampling period) values for each river were estimated using the equation from Fontaine and others (1992) and the predicted changes in mean annual precipitation, drainage areas, and mean channel elevation. Fluxes were normalized to entire or total island areas. TOC, total organic carbon; DIC, dissolved inorganic carbon; $\mathrm{TgC} / \mathrm{yr}$, teragrams of carbon per year; $\mathrm{gC} / \mathrm{m}^{2} / \mathrm{yr}$, grams of carbon per square meter per year]

\begin{tabular}{|c|c|c|c|c|c|c|}
\hline Island & $\begin{array}{c}\text { Projected TOC } \\
\text { flux } \\
\text { (TgC/yr) }\end{array}$ & $\begin{array}{c}\text { Projected TOC } \\
\text { yield } \\
\left(\mathrm{gC} / \mathrm{m}^{2} / \mathrm{yr}\right)\end{array}$ & $\begin{array}{c}\text { Projected DIC flux } \\
\text { (TgC/yr) }\end{array}$ & $\begin{array}{l}\text { Projected DIC yield } \\
\left(\mathrm{gC} / \mathrm{m}^{2} / \mathrm{yr}\right)\end{array}$ & $\begin{array}{c}\text { Projected total } \\
\text { surface flux ( } \mathrm{TgClyr})\end{array}$ & $\begin{array}{l}\text { Projected total } \\
\text { surface yield } \\
\left(\mathrm{gC} / \mathrm{m}^{2} / \mathrm{yr}\right)\end{array}$ \\
\hline Hawai'i & $\begin{array}{l}0.018 \\
(0.009)\end{array}$ & $\begin{array}{c}7.37 \\
(3.75)\end{array}$ & $\begin{array}{l}0.005 \\
(0.002)\end{array}$ & $\begin{array}{l}2.31 \\
(0.84)\end{array}$ & $\begin{array}{c}0.023 \\
(0.011)\end{array}$ & $\begin{array}{l}9.68 \\
(4.59)\end{array}$ \\
\hline Kaua'i & $\begin{array}{l}0.017 \\
(0.004)\end{array}$ & $\begin{array}{l}13.99 \\
(3.62)\end{array}$ & $\begin{array}{l}0.005 \\
(0.001)\end{array}$ & $\begin{array}{c}3.71 \\
(0.99)\end{array}$ & $\begin{array}{c}0.022 \\
(0.005)\end{array}$ & $\begin{array}{l}17.71 \\
(4.61)\end{array}$ \\
\hline Moloka‘i & $\begin{array}{c}0.003 \\
(0.003)\end{array}$ & $\begin{array}{c}7.43 \\
(5.91)\end{array}$ & $\begin{array}{c}0.001 \\
(0.001)\end{array}$ & $\begin{array}{l}2.80 \\
(1.34)\end{array}$ & $\begin{array}{c}0.004 \\
(0.004)\end{array}$ & $\begin{array}{l}10.23 \\
(7.26)\end{array}$ \\
\hline Maui & $\begin{array}{c}0.012 \\
(0.007)\end{array}$ & $\begin{array}{l}15.01 \\
(9.04)\end{array}$ & $\begin{array}{c}0.004 \\
(0.002)\end{array}$ & $\begin{array}{c}4.94 \\
(1.92)\end{array}$ & $\begin{array}{c}0.016 \\
(0.009)\end{array}$ & $\begin{array}{l}19.95 \\
(10.96)\end{array}$ \\
\hline O'ahu & $\begin{array}{c}0.018 \\
(0.006)\end{array}$ & $\begin{array}{l}16.00 \\
(5.47)\end{array}$ & $\begin{array}{l}0.005 \\
(0.001)\end{array}$ & $\begin{array}{l}4.45 \\
(1.26)\end{array}$ & $\begin{array}{l}0.023 \\
(0.007)\end{array}$ & $\begin{array}{l}20.45 \\
(6.73)\end{array}$ \\
\hline Total & $\begin{array}{c}0.069 \\
(0.029)\end{array}$ & $\begin{array}{l}11.35 \\
(4.87)\end{array}$ & $\begin{array}{c}0.020 \\
(0.007)\end{array}$ & $\begin{array}{l}3.38 \\
(1.13)\end{array}$ & $\begin{array}{c}0.089 \\
(0.036)\end{array}$ & $\begin{array}{l}14.72 \\
(6.00)\end{array}$ \\
\hline
\end{tabular}

Table 7.4. Comparison between total particulate carbon flux and yield estimates for three watersheds on the north Hilo coast of Hawaii Island during the calendar year 2013.

[Total particulate carbon flux and yield estimates using sub-daily flow with sub-daily total particulate carbon measurements and LOADEST Fortran model. Mean annual rainfall from Giambelluca and others (2013) except rainfall above 1,800 m, which is from Strauch and others (2015). $Q_{50}$ is the annual median streamflow that occurred during the sampling period (Strauch and others, 2015). TPC, total particulate carbon; mm/yr, millimeters per year; $\mathrm{kgC} / \mathrm{yr}$, kilograms of carbon per year; $\mathrm{gC} / \mathrm{m}^{2} / \mathrm{yr}$, grams of carbon per square meter per year]

\begin{tabular}{|c|c|c|c|c|c|c|c|}
\hline Watershed & $\begin{array}{l}\text { Watershed Area } \\
\qquad\left(\mathbf{k m}^{2}\right)\end{array}$ & $\begin{array}{l}\text { Mean annual } \\
\text { rainfall (mm/yr) }\end{array}$ & $\mathbf{Q}_{50}$ & $\begin{array}{l}\text { Observed } \\
\text { TPC flux } \\
\text { (kgC/yr) }\end{array}$ & $\begin{array}{l}\text { Estimated } \\
\text { TPC flux } \\
\text { (kgC/yr) }\end{array}$ & $\begin{array}{l}\text { Observed TPC yield } \\
\qquad\left(\mathrm{gC} / \mathrm{m}^{2} / \mathrm{yr}\right)\end{array}$ & $\begin{array}{l}\text { Estimated TPC yield } \\
\qquad\left(\mathrm{gC} / \mathrm{m}^{2} / \mathrm{yr}\right)\end{array}$ \\
\hline Umauma & 74.332 & 5,582 & 0.331 & $1,225,825$ & 726,322 & 16.491 & 9.771 \\
\hline Pahale & 10.143 & 4,968 & $<0.001$ & 730,122 & 227,757 & 71.982 & 22.454 \\
\hline Manowaiopae & 3.836 & 4,689 & 0.004 & 155,391 & 37,902 & 40.509 & 9.881 \\
\hline
\end{tabular}

Table 7.5. Mean groundwater dissolved inorganic carbon concentration, total submarine groundwater discharge, and total groundwater dissolved inorganic carbon flux for each island.

[Carbon flux (C flux) was calculated as the sum of the carbon fluxes of each hydrologic unit, and therefore differs slightly from the product of the dissolved inorganic carbon (DIC) concentration and submarine groundwater discharge (SGD). mgC/L, milligrams of carbon per liter; $\mathrm{km}^{3} / \mathrm{yr}$, cubic kilometers per year; $\mathrm{TgC} / \mathrm{yr}$, teragrams of carbon per year]

\begin{tabular}{|c|c|c|c|c|c|}
\hline Island & $\begin{array}{c}\text { Mean DIC } \\
(\mathrm{mgC} / \mathrm{L})\end{array}$ & SGD $\left(\mathrm{km}^{3} / \mathrm{yr}\right)$ & C flux (TgC/yr) & $\begin{array}{l}\text { Projected future } \\
\text { SGD (km³/yr) }\end{array}$ & $\begin{array}{c}\text { Projected future } \\
\text { C flux (TgC/yr) }\end{array}$ \\
\hline Kaua'i & $24.2 \pm 6.6$ & 0.90 & 0.023 & 0.97 & 0.025 \\
\hline O`ahu & $21.2 \pm 7.7$ & 1.18 & 0.024 & 1.19 & 0.024 \\
\hline Moloka'i & $15.7 \pm 4.4$ & 0.26 & 0.004 & 0.27 & 0.004 \\
\hline Lāna'i & 21.0 & 0.09 & 0.002 & 0.08 & 0.002 \\
\hline Maui & $22.2 \pm 9.9$ & 1.56 & 0.032 & 2.14 & 0.042 \\
\hline Kaho'olawe & 23.9 & 0.01 & 0.0002 & 0.01 & 0.0002 \\
\hline Hawai‘i & $16.9 \pm 10.1$ & 9.12 & 0.146 & 11.54 & 0.184 \\
\hline Total & $20.0 \pm 8.7$ & 13.11 & 0.230 & 16.20 & 0.281 \\
\hline
\end{tabular}




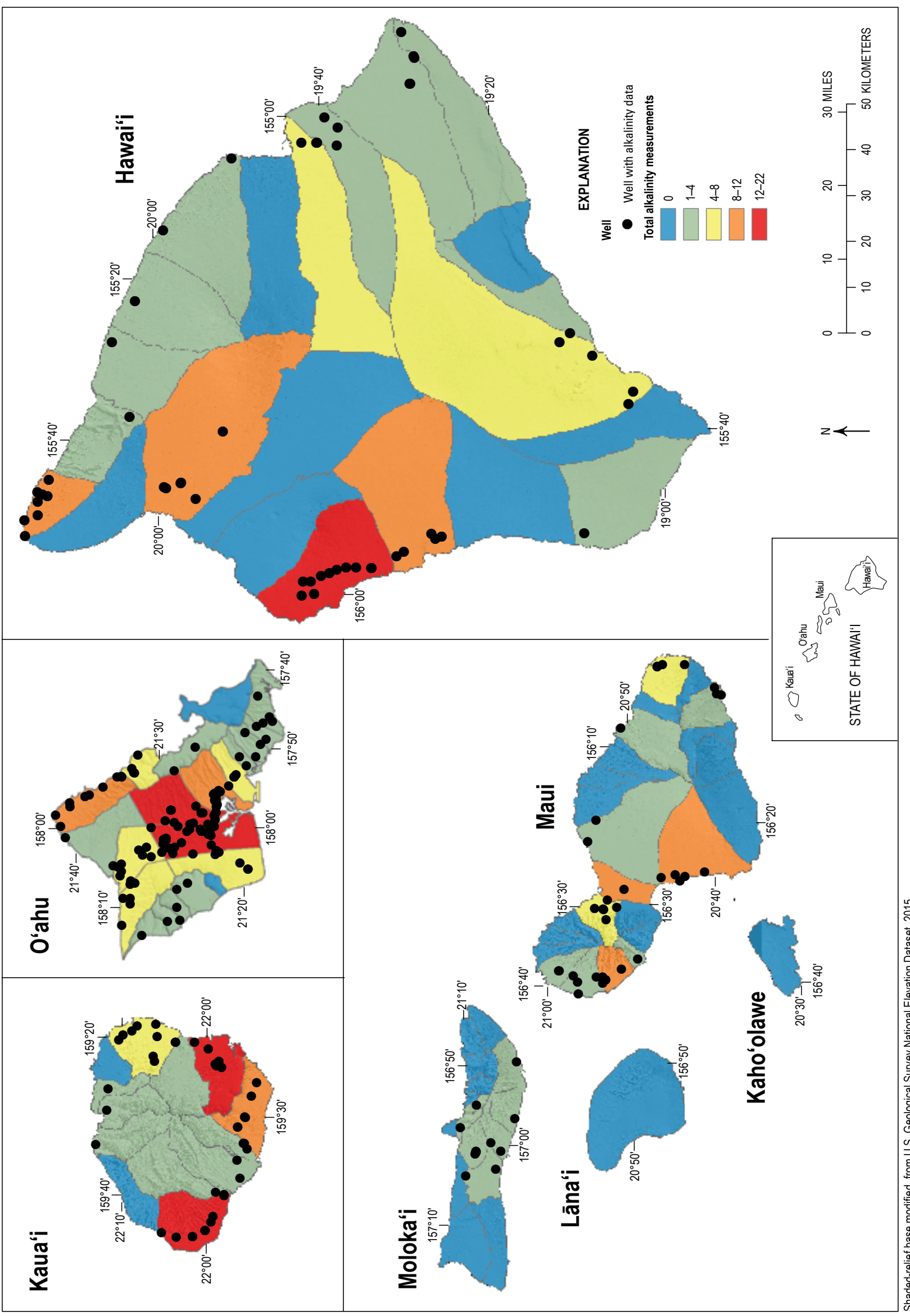

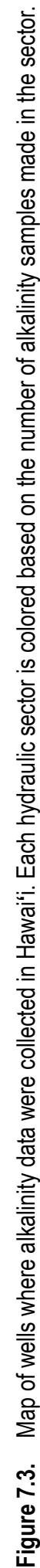


SGD differed widely among hydrologic units (from $0.01 \times$ $10^{6}$ to $3.96 \times 10^{6} \mathrm{~m}^{3} / \mathrm{d}$ ), largely depending on rainfall and surface area (fig. 7.5). The largest SGD estimates were on the windward slopes of Hawai'i Island and Maui, whereas lower discharges are predicted for leeward parts of the islands. The flux of DIC from each aquifer sector was calculated as the product of the SGD and DIC concentrations. In general, the largest DIC fluxes were from hydrologic units with the largest SGD, such as on the windward coasts of Hawai'i Island, Maui, and Moloka'i (fig. 7.5). The greatest flux was on Hawai' $i$ Island, accounting for 71 percent of the total (table 7.5). Although the DIC concentration was greatest on Kaua' $i$, the flux was not as large as other islands owing to the smaller SGD.

DOC was measured in 56 unique wells, concentrated on O'ahu (mean: $0.44 \pm 1.01 \mathrm{mg}$ DOC/L) and in the Kamaole system in central Maui (mean: $0.80 \pm 0.66 \mathrm{mg}$ DOC/L). Given the paucity of data available, a mean concentration of all samples $(0.50 \pm 0.96 \mathrm{mg} \mathrm{DOC} / \mathrm{L})$ was used to calculate a statewide average groundwater flux to the ocean of $0.007 \mathrm{TgC} / \mathrm{yr}$.

\subsubsection{Future Changes to Carbon Inputs to Nearshore Waters}

The HRCM-based climate projections show general precipitation shifts that include a 17.1-39.5 percent increase in precipitation on wet windward areas of Hawai'i and Maui, a 0.3-2.7 percent increase on the remaining islands, and a general slight drying trend across the drier areas of the islands. Increased rainfall is expected to increase stream and SGD carbon fluxes to Hawaiian nearshore waters. This is expected to increase stream carbon fluxes by nearly 10 percent, from $0.081 \pm 0.034$ to $0.089 \pm 0.036 \mathrm{TgC} / \mathrm{yr}$, with greatest increases expected from Maui (21.6 percent) and Hawai ${ }^{i} \mathrm{i}$ (18.3 percent) (table 7.3). Stream TOC fluxes will increase by nearly 10 percent and DIC will increase by 8 percent (table 7.3). SGD DIC fluxes will have a greater response, increasing by 24 percent and raising SGD fluxes from 0.228 to $0.279 \mathrm{TgC} / \mathrm{yr}$ (table 7.5 and fig. 7.6). Again, the statewide increase is dominated by the large SGD of Hawai' $i$ Island. Assuming the DIC concentration of groundwater remains constant, the statewide DIC flux will also increase by 22 percent. The only projected decreases in DIC flux were for the islands with the least data, Kaho'olawe and Lāna'i.

\subsection{Discussion}

Streams, rivers, and groundwater provide an important mechanism for processing and delivering particulate and dissolved forms of carbon to nearshore waters (Datry and others, 2014). Once thought to be simple conduits of carbon, streams and rivers process nearly half of the terrestrial carbon inputs before they are delivered to the ocean. The rest is buried within the system or lost to the atmosphere through various physical, biogeochemical, and ecological processes (Cole and others, 2007). Streams and groundwater likely play similar roles in Pacific Island carbon cycles, yet few studies have attempted to construct entire carbon budgets for this region. This is particularly important in the tropics because carbon fluxes to nearshore waters from perennial streams and submarine groundwater discharge are a valuable energy source that supports sustainable levels of coastal primary productivity (Hoover and others, 2006; Mead and Wiegner, 2010; Johnson and Wiegner, 2014) and secondary productivity (Atwood and others, 2012). Our results provide an initial assessment of surface and groundwater carbon inputs to Hawaiian nearshore waters. Inputs were dominated by DIC fluxes from SGD, whereas total organic carbon fluxes were largely due to surface water inputs and both of these fluxes are expected to increase under future climate scenarios. Higher inputs of DIC from SGD sources are likely due to the fact that estimates from SGD encompassed entire island areas, whereas surface water inputs were only calculated for perennial streams and were limited to perennial watershed scales. Higher total organic carbon values were likely due to the fact that SGD flowing through aquifers lacks the particulate carbon sources that dominate surface water carbon loading (Johnson and Wiegner, 2014). Comparisons across islands revealed that DIC in SGD decreased with decreasing island area; Hawai'i Island had the most SGD DIC, whereas Moloka' $i$ had the least. Stream carbon fluxes were much more variable. A general lack of data limited our ability to estimate accurate stream and groundwater inputs or examine what factors (for example, land use, rainfall, streamflow) have the greatest influence on carbon loading to nearshore waters.

\subsubsection{Stream Carbon Inputs}

The initial correlation analysis revealed that carbon loading was best predicted by median streamflow; none of the other land-use categories - such as forest cover, percent agriculture, or impervious services - that are known to influence surface runoff, and thus carbon loading, proved to be effective predictors of carbon loading (Booth and others, 2002; Bruland and MacKenzie, 2010). This is likely due to the fact that only 16 values were used in the initial analysis. Additional data points will increase our ability to correlate carbon fluxes to other land uses and increase the robustness of our model.

Stream carbon inputs for the State of Hawai' $i$ are likely to be underestimates for several reasons. First, as identified above, carbon outputs for 401 streams were modeled from LOADEST output from only 16 streams. Additional streamgages coupled with water quality and quantity monitoring would alleviate this data gap and increase the robustness of this effort. Second, surface water estimates only included perennial streams and ignored intermittent or ephemeral streams. Intermittent rivers, which are rarely monitored because of their limited economic importance, are a potentially important source of carbon across the Hawaiian Islands because of their extent along the leeward sides of the islands and because of the carbon dynamics that occur within them. Leaf litter and other forms of particulate organic carbon can accumulate in drying or dried streambeds (Acuña and Tockner, 2010; Corti and others, 2011). Lower flow in drying streams can also result in increased leaf-litter breakdown, likely through increased water temperatures and increased bacterial activity (MacKenzie and others, 2013; Roberts and others, 2016). Breakdown in dried-out 


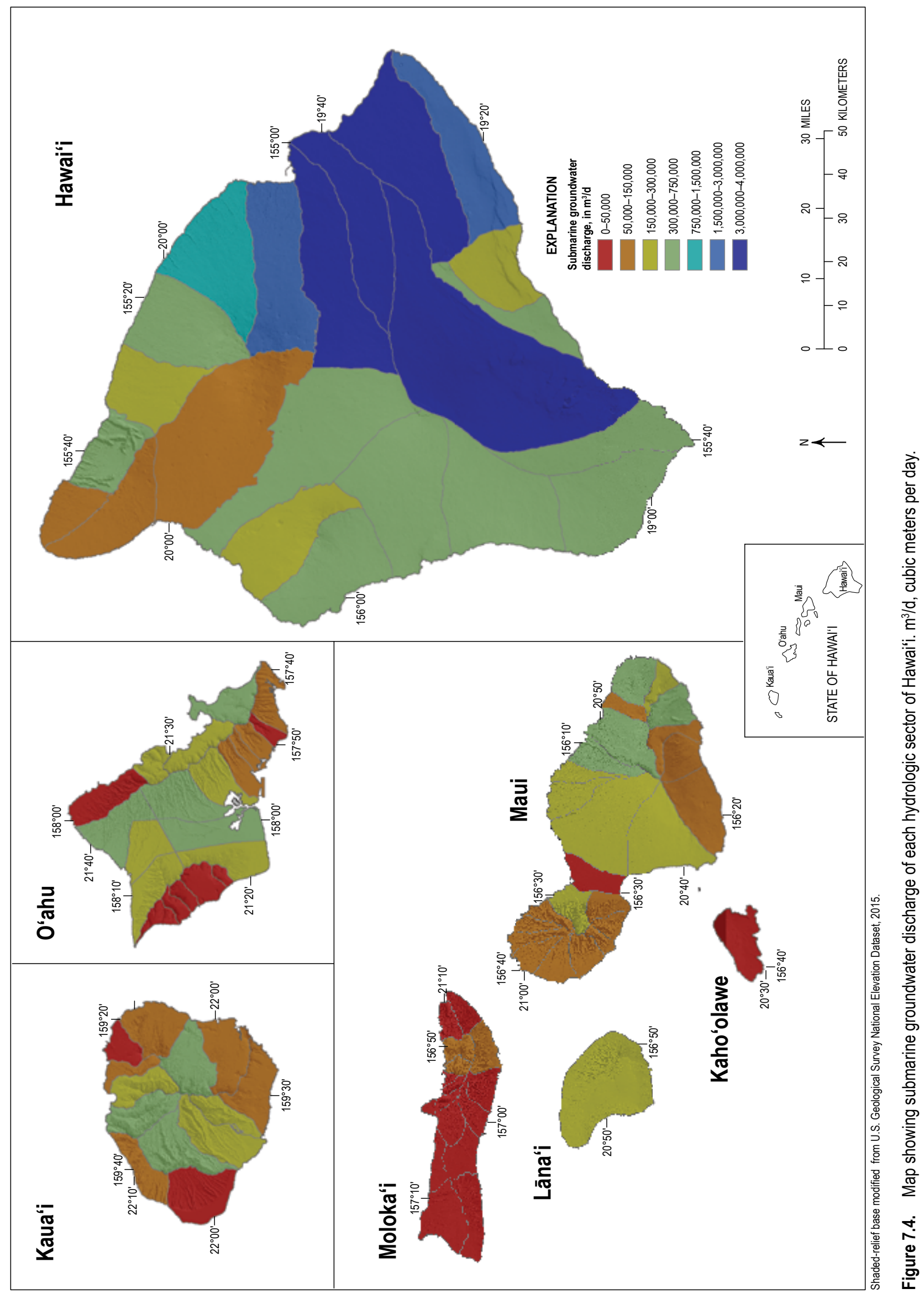




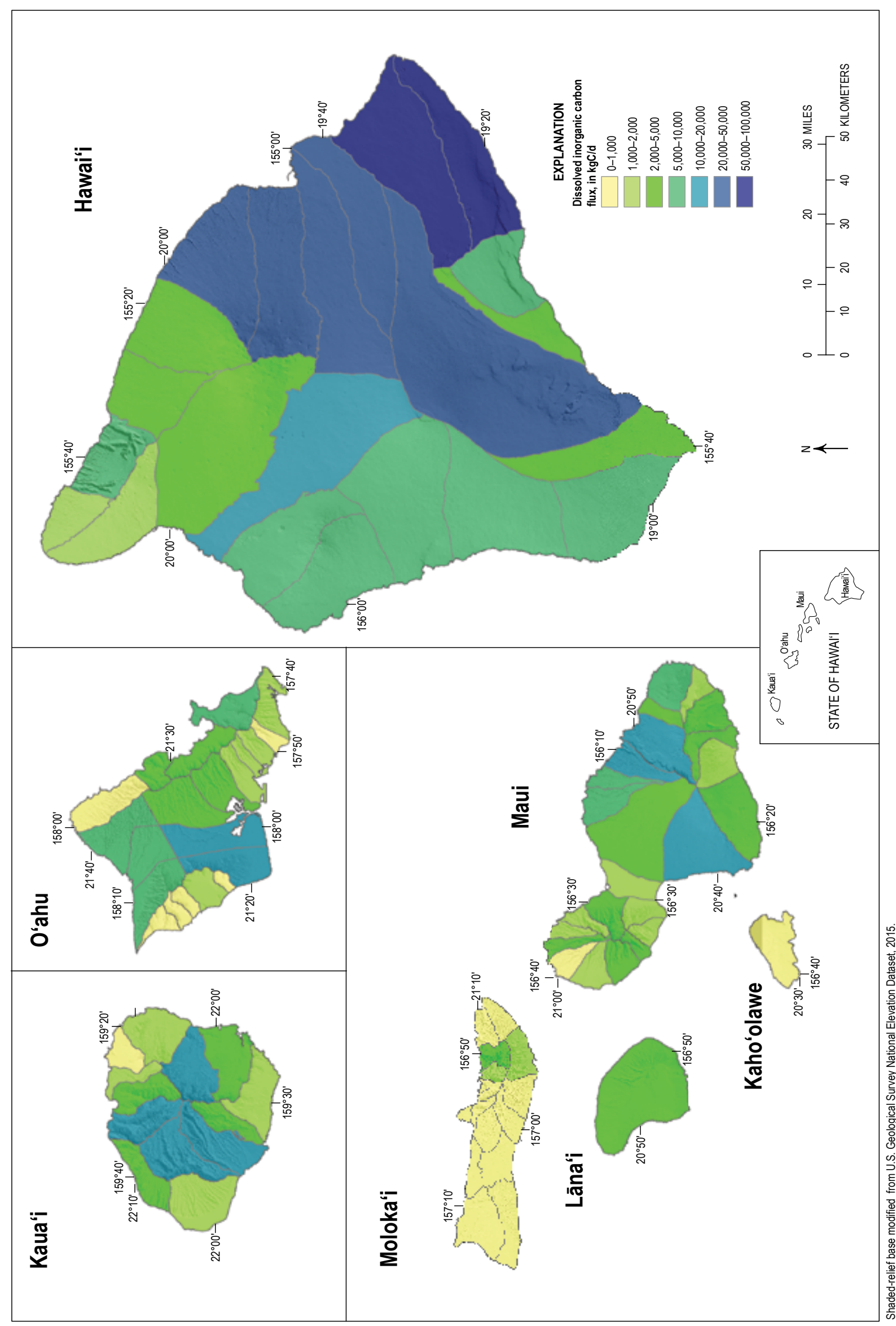

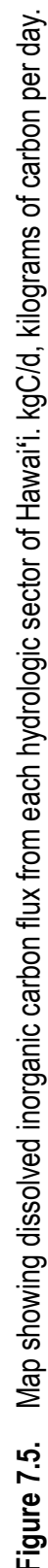



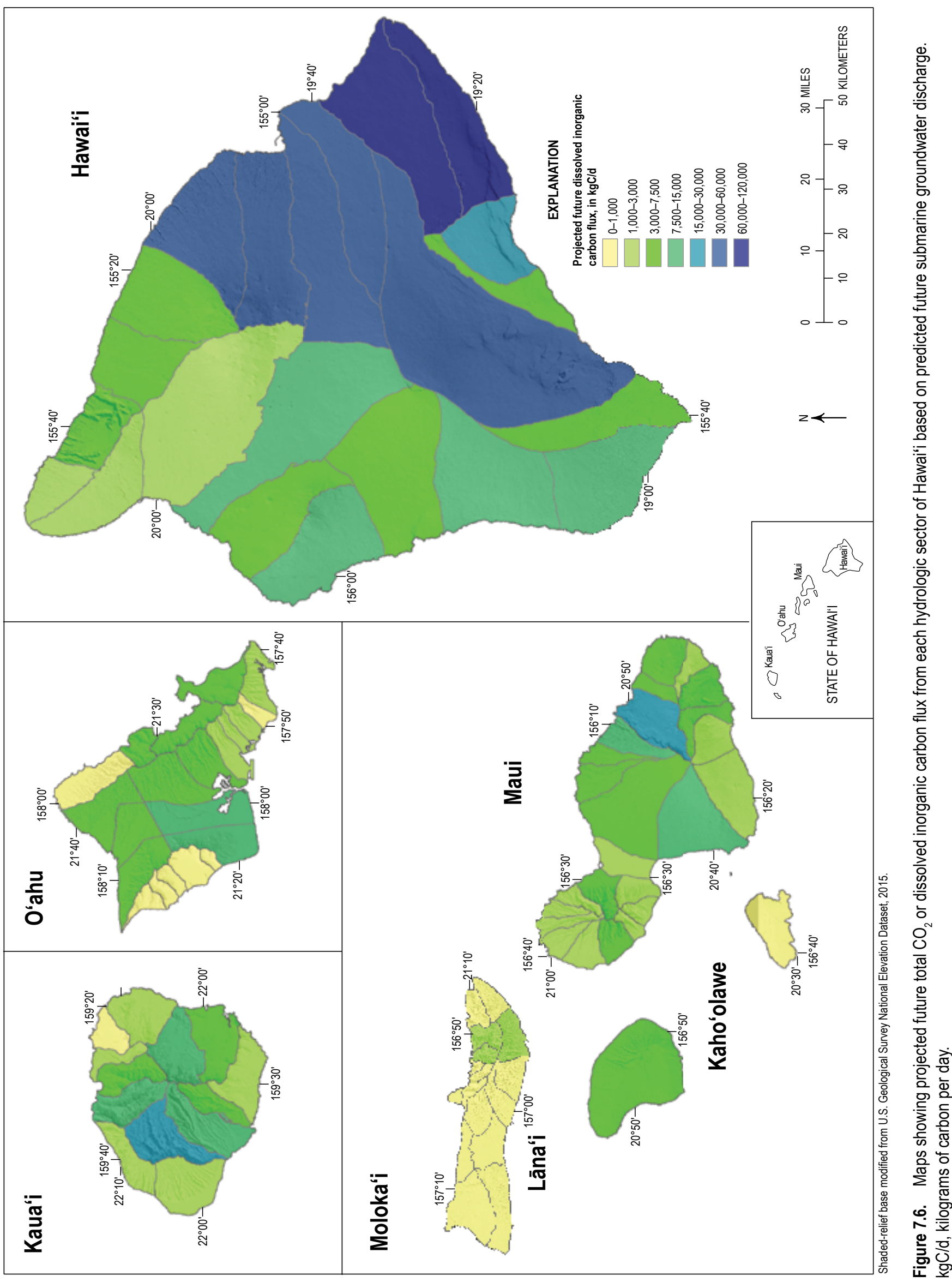
streambeds by terrestrial organisms or photo-degradation can continue to occur (Austin and Vivanco, 2006; Corti and others, 2011). When flow returns to these intermittent streams, that carbon is quickly transported to the ocean at initial concentrations that can be much higher than those observed in baseflow or in lower flowing streams (Jacobson and others, 2000; Larned and others, 2010; Corti and Datry, 2012). Lastly, LOADEST underestimated particulate carbon flux from three streams where we were able to do a direct comparison between actual observed and modelled values and the level of inaccuracy appeared to increase with decreasing watershed area, rainfall, and median flow. This is likely due to the fact that flow is more variable in the drier streams (Strauch and others, 2015), which would increase the level of uncertainty in the output of the LOADEST model. LOADEST was also developed for continental watersheds, so it is possible that this model may not be adequate for the steeply sloped and spatially compact Pacific-island watersheds that respond more rapidly to rainfall events than larger continental watersheds.

\subsubsection{Submarine Groundwater Discharge}

The DIC flux from each island was primarily controlled by the SGD, which varied by nearly three orders of magnitude. Windward Hawai'i Island, with high rates of rainfall and large watersheds, was the dominant source of DIC from groundwater to the ocean. In particular, the surfaces of Mauna Loa and Killauea, with little soil development and the intrinsic high permeability of basalt lava flows, result in very high rates of groundwater recharge to rainfall (Engott, 2011). The predicted increase in SGD for Hawai' $i$ Island is greater than the combined SGD of Kaua' $i$, O'ahu, Moloka'i, Lāna'i, and Kaho'olawe, emphasizing the importance of understanding the hydrology of Hawai' $i$ Island. Although this study assumed that all SGD flows out of basal aquifers, deep confined aquifers have been identified (Thomas and others, 1996). However, little is known about the distribution, magnitude of flow, or geochemistry of these deep aquifers. Further studies that refine our understanding of island hydrology will improve estimates of SGD and DIC fluxes, particularly for the rainfall at high elevation that seems to feed these confined aquifers.

Several limitations to the DIC flux estimate were identified with this study. First is the lack of groundwater DIC data. Here, we used available alkalinity and $\mathrm{pH}$ data to calculate DIC, but there are significant uncertainties in this method: not having paired $\mathrm{pH}$ and alkalinity measurements (and sometimes using data from different wells), the low resolution of the $\mathrm{pH}$ data (only to one decimal point), and unknown temperature of analyses. DIC is critical in studying the carbon cycle and the flow of carbon between systems. In Hawai' $i$, the statewide mean DIC was less than the DIC of surface seawater near Hawai' i ( $23.7 \mathrm{mgC} / \mathrm{L}$; Brix and others, 2004). Thus, SGD flowing into the coastal ocean will likely reduce the aragonite saturation, which will reduce the ability of organisms to form calcium carbonate structures. This has the potential to enhance the effects of ocean acidification in the coastal ocean. DIC should be a parameter that is explicitly measured.
There was also a paucity of alkalinity measurements, with 36 percent of aquifer sectors statewide lacking alkalinity measurements and only 39 percent having more than two measurements. A concerted effort to collect data statewide and analyzed with a consistent method (such as DIC analysis) would be a great improvement. Given the importance of SGD on the flux of DIC to the ocean, locations with the highest SGD that are lacking DIC data should be priority sites for gathering data. These include the Hilo, Anaehoomalu, and Kaapuna systems on Hawai'i Island and Waikamoi and Keanae systems on Maui. For DOC, statewide measurements are needed, but again, based on the importance of SGD, sites on Hawai'i Island and east Maui should have the highest priority.

Unfortunately, the SGD estimates were calculated using a variety of different spatial modeling methods. For example, some of the data from Maui did not include fog drip in the hydrologic budget (Shade, 1997; Engott and Vana, 2007). Further, the model for O'ahu was not defined along aquifer sectors, requiring further analysis to be similar to the other islands. No recent studies of SGD are available for Kaho'olawe. Fortunately, the USGS is presently updating the hydraulic budgets of the main Hawaiian Islands, which will help refine this model (Engott and others, 2015).

\subsubsection{Projected Future Changes in Stream and SGD Carbon Fluxes}

Using HRCM predictions of changes in rainfall, reanalysis of both stream and SGD datasets revealed that both stream and SGD carbon fluxes would increase under future climate conditions as predicted by the HRCM. This was largely due to increases in stream and SGD fluxes from Hawai' $i$ and Maui Islands, where the HRCM predicted significant increases in rainfall along wet, windward coasts. Although the HRCM predicts increased rainfall on the wetter side of Hawaiian Islands, changes in the distribution of this increased rainfall remain unclear. Other models have predicted similar scenarios with an increase in rainfall events, but this increase is due to fewer but more intense storms, with a greater number of dry days in between (Chu and Chen, 2005; Chu and others, 2010; Timm and others, 2011). Although our models suggest increased carbon fluxes, it's not entirely clear how changes in timing of surface water flow will impact carbon dynamics or TOC versus DIC dynamics. Decreased flow rates during dry days will likely increase breakdown rates of particulate organic matter (Corti and others, 2011; Roberts and others, 2016) and potentially shift the proportion of TOC versus DIC fluxes from streams. Another limitation to our model is that it does not take into account warming-related shifts in the riparian community and the impact this will have on hydrological and organic matter cycling in Hawaiian streams (Ayron M. Strauch, Hawaii Department of Land and Natural Resources, unpublished data; MacKenzie and others, 2013). This is of particular concern in Hawai' $i$ as exotic species are taking over native ecosystems at alarming rates (Asner and others, 2008; Denslow and others, 2009) and this is expected to have severe consequences on stream function (Kominoski and others, 2013). 


\subsection{References Cited}

Acuña, V., and Tockner, K., 2010, The effects of alterations in temperature and flow regime on organic carbon dynamics in Mediterranean river networks: Global Change Biology, v. 16, no. 9, p. 2638-2650, available at http://dx.doi.org/10.1111/ j.1365-2486.2010.02170.x.

Asner, G.P., Hughes, R.F., Vitousek, P.M., Knapp, D.E., Kennedy-Bowdoin, T., Boardman, J., Martin, R.E., Eastwood, M., and Green, R.O., 2008, Invasive plants transform the three-dimensional structure of rain forests: Proceedings of the National Academy of Sciences, v. 105, no. 11, p. $4519-4523$.

Atwood, T.B., Wiegner, T., and MacKenzie, R.A., 2012, Effects of hydrological forcing on the structure of a tropical estuarine food web: Oikos, v. 121, no. 2, p. 277-289, available at http://dx.doi. org/10.1111/j.1600-0706.2011.19132.x.

Austin, A.T., and Vivanco, L., 2006, Plant litter decomposition in a semi-arid ecosystem controlled by photodegradation, Nature, v. 442, p. $555-558$.

Bassiouni, M., and Oki, D.S., 2013, Trends and shifts in streamflow in Hawai' i, 1913-2008: Hydrologic Processes, v. 27 , no. 10 , p. 1484-1500, available at http://dx.doi. org/10.1002/hyp.9298.

Benstead, J.P., March, J.G., Pringle, C., Ewel, K.C., and Short, J.W., 2009, Biodiversity and ecosystem function in species-poor communities - Community structure and leaf litter breakdown in a Pacific island stream: Journal of the North American Benthological Society, v. 28 , no. 2, p. 454 465 , available at http://dx.doi.org/10.1899/07-081.1.

Bishop, Y.M.M., Fienberg, S.E., and Holland, P.W., 1975, Discrete Multivariate Analysis - Theory and Practice: Cambridge, Mass., MIT Press, 557 p.

Booth, D.B., Hartley, D., and Jackson, R., 2002, Forest cover, impervious surface area, and the mitigation of stormwater impacts: Journal of the American Water Resources Association, v. 38 , no. 3 , p. $835-845$.

Bright, G.R., 1982, Secondary benthic production in a tropical island stream: Limnology and Oceanography, v. 27, no. 3, p. $472-480$.

Bruland, G.L., and MacKenzie, R.A., 2010, Nitrogen source tracking with $\delta^{15} \mathrm{~N}$ content of coastal wetland plants in Hawaii: Journal of Environmental Quality, v. 39, no. 1, p. 409-419, available at https://dx.doi.org/10.2134/jeq2009.0005.

Chu, P.-S., and Chen, H., 2005, Interannual and interdecadal rainfall variations in the Hawaiian islands: Journal of Climate, v. 18 , no. 22 , p. $4796-4813$.
Chu, P.-S., Chen, Y.R., and Schroeder, T.A., 2010, Changes in precipitation extremes in the Hawaiian Islands in a warming climate: Journal of Climate, v. 23, p. 4881-4900 available at http://dx.doi.org/10.1175/2010JCLI3484.1.

Cole, J.J., Prairie, Y.T., Caraco, N.F., McDowell, W.H., Tranvik, L.J., Striegl, R.G., Duarte, C.M., Kortelainen, P., Downing, J.A., and Middelburg, J.J., 2007, Plumbing the global carbon cycle: integrating inland waters into the terrestrial carbon budget: Ecosystems, v. 10, p. 172-185.

Corti, R., and Datry, T., 2012, Invertebrates and sestonic matter in an advancing wetted front travelling down a dry river bed (Albarine, France): Freshwater Science, v. 31, p. 1187-1201, available at http://dx.doi.org/10.1899/12-017.1.

Corti, R., Datry, T., Drummond, L., and Larned, S.T., 2011, Natural variation in immersion and emersion affects breakdown and invertebrate colonization of leaf litter in a temporary river: Aquatic Sciences, v. 73, p. 537-550, available at http://dx.doi. org/10.1007/s00027-011-0216-5.

Datry, T., Larned, S.L., and Tockner, K., 2014, Intermittent Rivers-A Challenge for Freshwater Ecology: BioScience, v. 64 , no. 3, p. 229-235, available at https://doi.org/10.1093/ biosci/bit027.

Denslow, J.S., Space, J.C., and Thomas, P.A., 2009, Invasive exotic plants in the tropical Pacific Islands - patterns of diversity: Biotropic, v. 41, p. 162-170.

Engott, J.A, 2011, A water-budget model and assessment of groundwater recharge for the Island of Hawai' $i$ i: U.S. Geological Survey Scientific Investigations Report 2011-5078, 53 p., https://pubs.usgs.gov/sir/2011/5078/.

Engott, J.A., Johnson, A.G., Bassiouni, Maoya, and Izuka, S.K., 2015, Spatially distributed groundwater recharge for 2010 land cover estimated using a water-budget model for the Island of O'ahu, Hawai'i: U.S. Geological Survey Scientific Investigations Report 2015-5010, 49 p., http://dx.doi. org $/ 10.3133 /$ sir20155010.

Engott, J.A., and Vana, T.T., 2007, Effects of agricultural landuse changes and rainfall on ground-water recharge in central and west Maui, Hawai'i, 1926-2004: U.S. Geological Survey Scientific Investigations Report 2007-5103, https://pubs.usgs. gov/sir/2007/5103/.

Fontaine, R.A., Wong, M.F., and Matsuoka, I., 1992, Estimation of median streamflows at perennial stream sites in Hawaii: U.S. Geological Survey Water-Resources Investigations Report 92-4099, $37 \mathrm{p}$.

Harrison, J.A., Caraco, N., and Seitzinger, S.P., 2005, Global patterns and sources of dissolved organic matter export to the coastal zone-Results from a spatially explicit, global model: Global Biogeochemical Cycles, v. 19, no. 4, 16 p. 
Hawaii Institute of Geophysics, University of Hawaii, 1983, Geothermal Resources of Hawaii: National Oceanic and Atmospheric Administration, National Geophysical Data Center, scale 1:5,000,000. [Also available at http://hdl. handle.net/10125/33594.]

Hoover, R., Hoover, D., Miller, M., Landry, M., DeCarlo, E., and Mackenzie, F., 2006, Zooplankton response to storm runoff in a tropical estuary-bottom-up and top-down controls: Marine Ecology Progress Series, v. 318, p. $187-201$.

Jacobson, P.J., Jacobson, K.M., Angermeier, P.L., and Cherry, D.S., 2000, Variation in material transport and water chemistry along a large ephemeral river in the Namib Desert: Freshwater Biology, v. 44, p. 481-491.

Johnson, E.E., and Wiegner, T.N., 2014, Surface water metabolism potential in groundwater-fed coastal waters of Hawai' $i$ Island, USA: Estuaries and Coasts, v. 37, no. 3, p. 712-723, available at http://dx.doi.org/10.1007/s12237013-9708-y.

Kominoski, J.S., Shah, J.J.F., Canhoto, C., Fischer, D.G., Giling, D.P., Gonzalez, E., Griffiths, N.A., Larranaga, A., LeRoy, C.J., and Mineau, M.M., 2013, Forecasting functional implications of global changes in riparian plant communities: Frontiers in Ecology and the Environment, v. 11, p. 423-432, available at http://dx.doi. org/10.1890/120056.

Larned, S.T., 2000, Dynamics of coarse riparian detritus in a Hawaiian stream ecosystem - a comparison of drought and post-drought conditions: Journal of the North American Benthological Society, v. 19, p. 215-234.

Larned, S.T., Datry, T., Arscott, D.B., and Tockner, K., 2010, Emerging concepts in temporary-river ecology: Freshwater Biology, v. 55, p. 717-738, available at http://dx.doi. org/10.1111/j.1365-2427.2009.02322.x.

Laws, E.A., and Ferentinos, L., 2003, Human impacts on fluxes of nutrients and sediment in Waimanalo Stream, O'ahu, Hawaiian Islands: Pacific Science, v. 57, p. 119-140.

MacKenzie, R.A., Wiegner, T.N., Kinslow, F., Cormier, N., and Strauch, A.M., 2013, Leaf-litter inputs from an invasive nitrogen-fixing tree influence organic-matter dynamics and nitrogen inputs in a Hawaiian river: Journal of Freshwater Science, v. 32, no. 3, p. 1036-1052, available at http:// dx.doi.org/10.1899/12-152.1.

Mead, L.H., and Wiegner, T.N., 2010, Surface water metabolism potential in a tropical estuary, Hilo Bay, Hawai ${ }^{i}$, USA, during storm and non-storm conditions: Estuaries and Coasts, v. 33, no. 5, p. 1099-1112, available at http://dx.doi.org/10.1007/s12237-010-9317-y.
Millero, F.J., 1979, The thermodynamics of the carbonate system in seawater: Geochimica et Cosmochimica Acta, v. 43 , p. 1651-1661.

Millward, A.A., and Mersey, J.E., 1999, Adapting the RUSLE to model soil erosion potential in a mountainous tropical watershed: Catena, v. 38, p. 109-129.

Mink, J.F., and Lau, L.S., 1990, Aquifer identification and classification for Oahu - Groundwater protection strategy for Hawaii: Honolulu, University of Hawai' $i$ at Mānoa, Water Resources Research Center Technical Report 179, 28 p.

Mink, J.F., and Lau, L.S., 1992, Aquifer identification and classification for Kauai-Groundwater protection strategy for Hawaii: Honolulu, University of Hawai' $i$ at Mānoa, Water Resources Research Center Technical Report 186, 37 p.

Mink, J.F., and Lau, L.S., 1993, Aquifer identification and classification for the Island of Hawaii: groundwater protection strategy for Hawaii: Honolulu, University of Hawai'i at Mānoa, Water Resources Research Center Technical Report 191, 108 p.

Polhemus, D.A., Englund, R.A., Jordan, S., and Polhemus, J., 2000, Trip report for 1999 entomological and freshwater surveys of the Smithsonian Institution and Bishop Museum expedition to the Marquesas Islands and Tahiti: Honolulu, Bishop Museum Report 2000-002, 17 p.

Prasannakumar, V., Vijith, H., Abinod, S., and Geetha, N., 2012, Estimation of soil erosion risk within a small mountainous sub-watershed in Kerala, India, using Revised Universal Soil Loss Equation (RUSLE) and geo-information technology: Geoscience Frontiers, v. 3, p. 209-215, available at http:// dx.doi.org/10.1016/j.gsf.2011.11.003.

Rea, Alan, and Skinner, K.D., 2012, Geospatial datasets for watershed delineation and characterization used in the Hawaii StreamStats web application: U.S. Geological Survey Data Series 680, 12 p. available at https://pubs.usgs.gov/ds/680/.

Resh, V.H., and deSzalay, F.A., 1995, Streams and rivers of Oceania, in Cushing, C.E., Cushing, K.W., and Minshall, G.W., eds., River and Stream Ecosystems: Elsevier, Amsterdam, p. 717-736.

Ringuet, S., and MacKenzie, F.T., 2005, Controls on nutrient and phytoplankton dynamics during normal flow and storm runoff conditions, Southern Kaneohe Bay, Hawai' ${ }^{i}$ : Estuaries, v. 28 , p. $327-337$.

Robbins, L.L., Hansen, M.E., Kleypas, J.A., and Meylan, S.C., 2010, CO2calc - A user-friendly seawater carbon calculator for Windows, Max OS X, and iOS (iPhone): U.S. Geological Survey Open-File Report 2010-1280, 17 p., available at https://pubs.usgs.gov/of/2010/1280/. 
Roberts, M., Strauch, A.M., Wiegner, T., and Mackenzie, R.A., 2016, Leaf litter breakdown of native and exotic tree species in two Hawaiian streams that differ in flow: Pacific Science, v. 70, p. 209-222, available at http://dx.doi.org/10.2984/70.2.7.

Runkel, R.L., Crawford, C.G., and Cohn, T.A., 2004, Load Estimator (LOADEST): A FORTRAN Program for Estimating Constituent Loads in Streams and Rivers: U.S. Geological Survey Techniques and Methods Book 4, Chapter A5, 69 p., available at https://pubs.usgs.gov/tm/2005/tm4A5/.

Shade, P.J., 1995, Water budget for the island of Kauai, Hawaii: U.S. Geological Survey Water-Resources Investigations Report 95-4128, $25 \mathrm{p}$.

Shade, P.J., 1997, Water budget for the island of Molokai, Hawaii: U.S. Geological Survey Water-Resources Investigations Report 97-4155, 20 p.

Shade, P.J., 1999, Water budget of east Maui, Hawaii: U.S. Geological Survey Water-Resources Investigations Report 98-4159, 36 p.

Shade, P.J., and Nichols, W.D., 1996, Water budget and the effects of land-use changes on ground-water recharge, Oahu, Hawaii: U.S. Geological Survey Professional Paper 1412-C, 38 p.

Stackpoole, S.M., Butman, D., Clow, D.W., McDonald, C.P., Stets, E.G., and Striegl, R.G., 2012, Baseline carbon sequestration, transport, and emission from inland aquatic ecosystems in the Western United States, chap. 10 of Zhu, Z., and Reed, B.C., eds., Baseline and projected future carbon storage and greenhouse-gas fluxes in ecosystems of the Western United States: U.S. Geological Survey Professional Paper 1797, 18 p. (Also available at http://pubs.usgs.gov/pp/1797/.)

Stenback, G.A., Crumpton, W.G., Schilling, K.E., and Helmers, M.J., 2011, Rating curve estimation of nutrient loads in Iowa Rivers: Journal of Hydrology, v. 396, p. 158-169, available at http://dx.doi.org/10.1016/j.jhydrol.2010.11.006.

Stets, E.G., and Striegl, R.G., 2012, Carbon export by rivers draining the conterminous United States: Inland Waters, v. 2, p. 177-184, available at http://dx.doi.org/10.5268/IW-2.4.510.

Strauch, A.M., Mackenzie, R.A., Bruland, G.L., Tingley, R.W., and Giardina, C.P., 2014, Climate change and land use drivers of fecal bacteria in tropical Hawaiian rivers: Journal of Environmental Quality, v. 43, p. 1475-1483, available at http:// dx.doi.org/10.2134/jeq2014.01.0025.
Strauch, A.M., MacKenzie, R.A., Giardina, C.P., and Bruland, G.L., 2015, Climate driven changes to rainfall and streamflow patterns in a model tropical island hydrological system: Journal of Hydrology, v. 523, p. 160-169, available at http:// dx.doi.org/10.1016/j.jhydrol.2015.01.045.

Thomas, D., Paillet, F., and Conrad, M., 1996, Hydrogeology of the Hawaii Scientific Drilling Project borehole KP-1-2. Groundwater geochemistry and regional flow patterns: Journal of Geophysical Research-Solid Earth, v. 101, p. 1168311694.

Timm, O.E., Diaz, H.F., Giambelluca, T.W., and Takahashi, M., 2011, Projection of changes in the frequency of heavy rain events over Hawaii based on leading Pacific climate modes: Journal of Geophysical Research-Atmospheres, v. 116, 12 p., available at http://dx.doi.org/10.1029/2010JD014923.

U.S. Geological Survey, 2012, USGS Water Data for the Nation: U.S. Geological Survey National Water Information System, accessed October 1, 2012, at http://waterdata.usgs.gov/nwis.

U.S. Geological Survey, 2014, USGS Water Data for Hawaii: U.S. Geological Survey National Water Information System, accessed October 1, 2014, at http://nwis.waterdata.usgs.gov/ hi/nwis/.

Vannote, R.L., Minshall, G.W., Cummins, K.W., Sedell, J.R., and Cushing, C.E., 1980, The river continuum concept: Canadian Journal of Fisheries \& Aquatic Sciences, v. 37, p. 130-137.

Webster, J.R., and Benfield, E.F., 1986, Vascular plant breakdown in freshwater ecosystems: Annual Review of Ecology and Systematics, v. 17, p. 567-594.

Wiegner, T., and Tubal, R.L., 2010, Comparison of dissolved organic carbon bioavailability from native and invasive vegetation along a Hawaiian river: Pacific Science, v. 64, p. 545-555, available at http://dx.doi.org/10.2984/64.4.545.

Wiegner, T.N., Tubal, R.L., and MacKenzie, R.A., 2009, Bioavailability and export of dissolved organic matter from a Hawaiian river during base- and stormflow conditions: Limnology and Oceanography, v. 54, p. 1233-1242.

Zhang, C., Wang, Y., Lauer, A., and Hamilton, K., 2012, Configuration and evaluation of the WRF model for the study of Hawaiian regional climate: Monthly Weather Review, v. 140 , no. 10 , p. 3259-3277, available at http://dx.doi. org/10.1175/MWR-D-11-00260.1. 



\title{
Chapter 8. Projected Future Carbon Storage and Carbon Fluxes in Terrestrial Ecosystems of Hawai'i from Changes in Climate, Land Use, and Disturbance
}

\author{
By Benjamin M. Sleeter, ${ }^{1}$ Jinxun Liu, ${ }^{1}$ Colin J. Daniel, ${ }^{2}$ Todd J. Hawbaker, ${ }^{1}$ Tamara S. Wilson, ${ }^{1}$ Lucas B. Fortini, ${ }^{1}$ James \\ D. Jacobi, ${ }^{1}$ Paul C. Selmants, ${ }^{1}$ Christian P. Giardina,${ }^{3}$ Creighton M. Litton, ${ }^{4}$ and R. Flint Hughes ${ }^{3}$
}

\subsection{Highlights}

- For the State of Hawai ' $i$, total carbon storage was projected to increase by about 6 percent $(14.7 \mathrm{TgC})$ to $267.6 \mathrm{TgC}$ in 2061 .

- Carbon stored in living biomass was projected to decrease by approximately 1.3 percent by 2061 , from $52.0 \mathrm{TgC}$ to $51.3 \mathrm{TgC}$; soil organic carbon was projected to increase from 183.6 $\mathrm{TgC}$ to $198.0 \mathrm{TgC}$.

- Net ecosystem production (NEP) for the State of Hawai ${ }^{i} \mathrm{i}$ was estimated at an average annual rate of $0.799 \mathrm{TgC} / \mathrm{yr}$ (mean annual NEP carbon flux density of $49 \mathrm{gC} / \mathrm{m}^{2} / \mathrm{yr}$ ). When land-use change and disturbances were considered, statewide net ecosystem carbon balance (NECB) was estimated at an average annual rate of $0.595 \mathrm{TgC} / \mathrm{yr}$ (mean annual NECB carbon flux density of $36 \mathrm{gC} / \mathrm{m}^{2} / \mathrm{yr}$ ). Both NEP and NECB were projected to decrease during the 50-year projection period, indicating a reduction in statewide carbon-sink strength. Developed lands were projected to more than double (increasing by $\sim 1,100 \mathrm{~km}^{2}$ ) by 2061 and account for 12.2 to 13.7 percent of the State's land area. Conversion to development would account for an average net annual loss of $0.1 \mathrm{TgC} / \mathrm{yr}$.

- Agricultural lands were projected to decrease sharply in the "business as usual" projection, with contraction rates $\left(\sim 45 \mathrm{~km}^{2} / \mathrm{yr}\right)$ more than double the rate of expansion $\left(20 \mathrm{~km}^{2} / \mathrm{yr}\right)$. Agricultural expansion accounted for an average annual loss of $0.078 \mathrm{TgC} / \mathrm{yr}$.

- Wildfire was projected to impact $41 \mathrm{~km}^{2} / \mathrm{yr}$ and burn 2,047 $\mathrm{km}^{2}$ by 2061. Grasslands accounted for 41 percent of all fire, shrublands accounted for 42 percent, and forests accounted for 17 percent. Fire was most common in the dry moisture zone (average of $31 \mathrm{~km}^{2} / \mathrm{yr}$ ), accounting for 76 percent of the annual burned area.

\footnotetext{
${ }^{1}$ U.S. Geological Survey.
}

${ }^{2}$ University of Toronto.

${ }^{3}$ U.S. Department of Agriculture Forest Service.

${ }^{4}$ University of Hawai'i i at Mānoa.
- Changes involving land-use transitions had the largest impact on total ecosystem carbon storage. Urbanization had the largest negative impact on total ecosystem carbon storage (from 4.0 to $7.4 \mathrm{TgC}$ ) and losses of agriculture had the strongest positive impact (from 7.4 to $10.4 \mathrm{TgC}$ ). By comparison, wildfire had a relatively small influence.

\subsection{Introduction}

Human caused changes in land use and land cover (LULC) can alter terrestrial ecosystem carbon stocks and carbon fluxes (Houghton and others, 1999). Since the first human occupants arrived more than 800 years ago, the native, natural landscapes of the Hawaiian Islands have undergone numerous waves of LULC change, from the first Hawaiians' efforts to grow food, fiber, and fuel, to widespread deforestation and introduction of exotic invasive plant species following European contact, to the more recent increase in urbanization. Given Hawai'i's volcanic composition, carbon-storage potential, and land-use history, it is important to assess the carbon sources and sinks under a range of controlling processes, including ecosystem changes resulting from climate change, wildfire, urbanization, and other anthropogenic drivers (Osher and others, 2003).

The Land Use and Carbon Scenario Simulator (LUCAS) model (Sleeter and others, 2015) was used to project changes in LULC and ecosystem carbon storage and flux under a "business as usual" (BAU) scenario for the State of Hawai 'i. This report describes the model and corresponding parameters (section 8.3), results of the simulations (section 8.4), as well as some of the key uncertainties and limitations of this study (section 8.5).

\subsection{Input Data and Methods}

The LUCAS model was used to understand how changes in land use and land cover - in particular urbanization, agricultural expansion and contraction, wildfire, and vegetation dynamicsaffect carbon storage and fluxes for the State of Hawai'i i. The LUCAS model is an integrated state-and-transition simulation 
and stock-flow (SF) model, which was linked to the Integrated Biosphere Simulator (IBIS) to provide carbon-flux rates. The LUCAS model produces spatially explicit projections of land change while also tracking the flow of carbon between various pools. See Sleeter and others (2015) for a complete description of the LUCAS model, including the linkage to IBIS. A description of the software and modeling framework used to implement the LUCAS model can be found in Daniel and Frid (2012) and Daniel and others (2016). The ST-SIM software application (ver. 3.0.17) can be downloaded from Apex Resources Management Solutions (http://www.apexrms.com).

\subsubsection{State Variables and Scales}

The modeling process covers most of the State of Hawai'i, including the islands of Hawai' $i$, Kaho'olawe, Kaua'i, Lāna' $i$, Maui, Moloka'i, and $\mathrm{O}^{\prime}$ ahu. The island of $\mathrm{Ni}^{\prime}$ 'ihau was not included in this analysis. Additionally, Hawai' $i$ was subdivided into three moisture zones - dry, mesic, and wet — and subdivided into 16,146 $1 \times 1-\mathrm{km}$ simulation cells (fig. 8.1). The temporal resolution of the model was set to annual timesteps.

The primary state variable tracked in the model was the state of each simulation cell. Each cell was assigned to 1 of 189 unique state-class types representing the combination of 3 moisture zones, 7 islands, and 9 LULC classes (forest, grassland, shrubland, tree plantation, developed, agriculture, barren, water, and wetland). In addition to the state of each cell, the LUCAS model tracks the age and the time since transition (TST) of each cell. For this model we tracked the age of forests, grasslands, shrublands, and tree plantations; TST was tracked for fire occurring on the grassland state class. No changes were simulated for water and wetland state-class types.

\subsubsection{Process Overview}

Transition pathways are defined as the set of changes that can move a cell from one state to another. Transition pathways are defined for all possible conversions simulated within the model. These include transitions associated with urbanization, agricultural expansion, agricultural contraction, wildfire, shrub encroachment, forest management, and changes in the size and spatial distribution of moisture zones under future projections of climate change. Within each timestep the ordering of the transition pathways was conducted randomly. Temporally, transition probabilities can be specified as static or varying. For this model we identified a total of 7 transition groups, 14 transition types, and 107 transition pathways (table 8.1). All transitions were modeled at an annual timestep.

Table 8.1. Transition pathways defined for the Land Use and Carbon Scenario Simulator (LUCAS) model.

[LULC, land use and land cover]

\begin{tabular}{|c|c|c|c|c|c|c|}
\hline \multirow{2}{*}{ Transition group } & \multirow{2}{*}{ Transition type } & \multirow{2}{*}{$\begin{array}{l}\text { Number of } \\
\text { pathways }\end{array}$} & \multicolumn{2}{|r|}{ From state } & \multicolumn{2}{|c|}{ To state } \\
\hline & & & Moisture zone & LULC class & Moisture zone & LULC class \\
\hline Agricultural expansion & Agricultural expansion & 9 & All & $\begin{array}{l}\text { Forest, shrubland, } \\
\text { grassland }\end{array}$ & All & Agriculture \\
\hline Agricultural contraction & Agricultural contraction & 9 & All & Agriculture & All & $\begin{array}{l}\text { Forest, shrubland, } \\
\text { grassland }\end{array}$ \\
\hline Urbanization & Urbanization & 15 & All & $\begin{array}{l}\text { Forest, shrubland, grassland, } \\
\text { agriculture, barren }\end{array}$ & All & Developed \\
\hline \multirow{2}{*}{ Management } & Forest plantation & 3 & All & Forest & All & Plantation \\
\hline & Plantation harvest & 3 & All & Plantation & All & Plantation \\
\hline Vegetation change & Shrub encroachment & 2 & $\begin{array}{l}\text { Dry } \\
\text { Mesic }\end{array}$ & Grassland & $\begin{array}{l}\text { Dry } \\
\text { Mesic }\end{array}$ & Shrubland \\
\hline Moisture zone change & Dry to mesic & 9 & Dry & All & Mesic & All \\
\hline \multicolumn{7}{|c|}{ Wildfire submodel } \\
\hline \multirow{3}{*}{ Wildfire } & High severity & 9 & All & $\begin{array}{l}\text { Forest } \\
\text { Shrubland } \\
\text { Grassland }\end{array}$ & All & $\begin{array}{l}\text { Grassland } \\
\text { Grassland } \\
\text { Grassland }\end{array}$ \\
\hline & Medium severity & 9 & All & $\begin{array}{l}\text { Forest } \\
\text { Shrubland } \\
\text { Grassland }\end{array}$ & All & $\begin{array}{l}\text { Forest } \\
\text { Shrubland } \\
\text { Grassland }\end{array}$ \\
\hline & Low severity & 9 & All & $\begin{array}{l}\text { Forest } \\
\text { Shrubland } \\
\text { Grassland }\end{array}$ & All & $\begin{array}{l}\text { Forest } \\
\text { Shrubland } \\
\text { Grassland }\end{array}$ \\
\hline
\end{tabular}




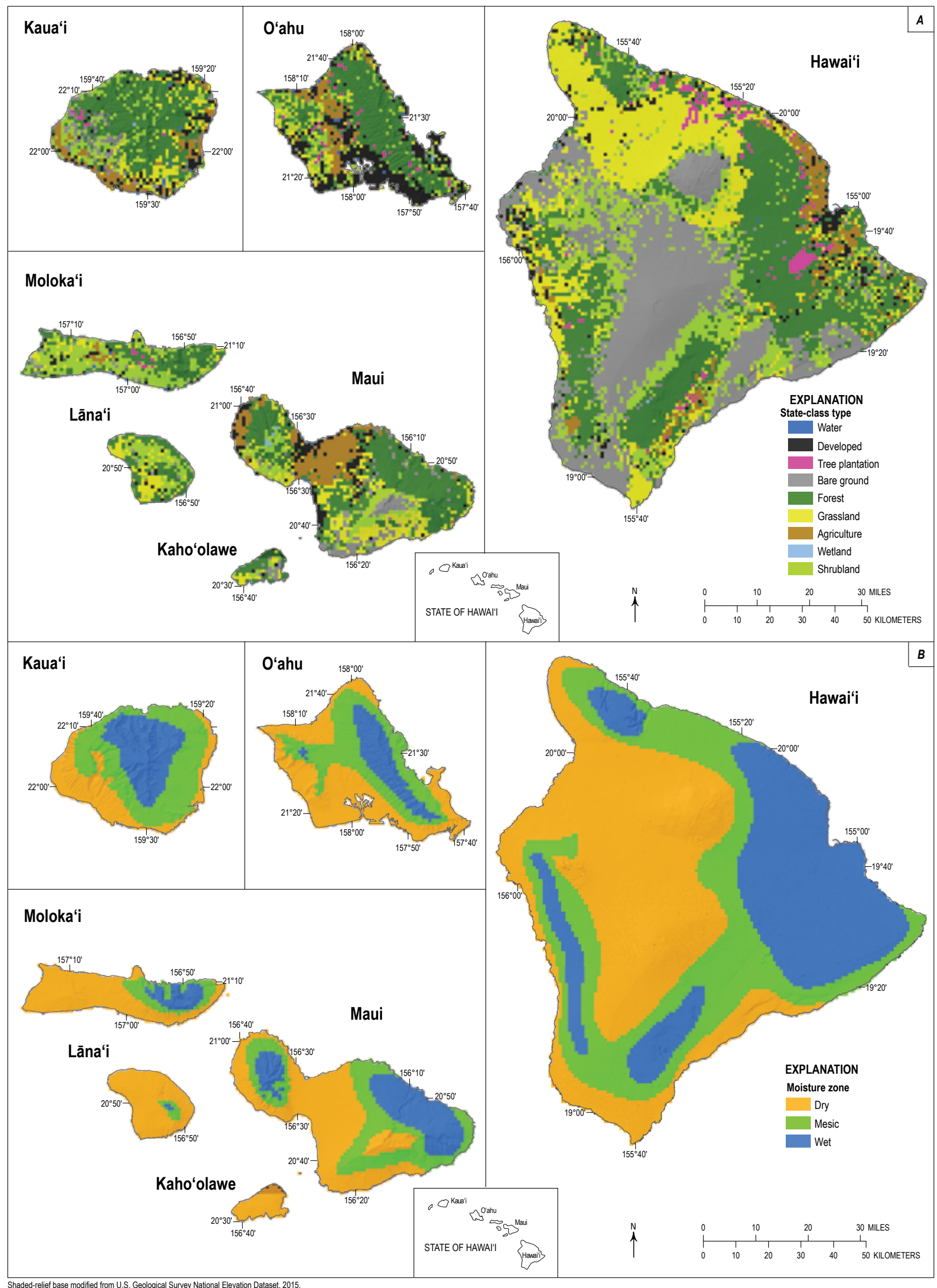

Figure 8.1. Maps showing state-class types $(A)$ and moisture zones $(B)$ used to initialize the Land Use and Carbon Scenario Simulator (LUCAS) model for Hawai'i. 


\subsubsection{Model Parameterization}

\subsubsection{Transition Probabilities}

Transition targets are used to model changes owing to agricultural expansion, agricultural contraction, urbanization, management, biome change, and moisture-zone change. Transition targets for agricultural expansion, agricultural contraction, and urbanization were based on a time series of change rates from remote-sensing-based mapping by the National Oceanic and Atmospheric Administrations (NOAA) Coastal Change Analysis Program (C-CAP). The C-CAP data provides classified land-cover images for Hawai' $i$ for the years 1992, 2001, 2005, and 2010 (NOAA, 2013). For these four dates and three temporal intervals we calculated the rate for each transition across the entire state. To represent this range of historical variability we sampled from a uniform distribution fitted to the minimum and maximum values from the C-CAP data (table 8.2). Transition targets to model changes in moisture zones were based on projections in Fortini and others (this volume, chap. 3). Maps of moisture-zone changes for the period 2000-2100 were used to calculate an annualized rate of change for each of the moisturezone conversions. These rates were then applied annually for each timestep within all Monte Carlo simulations of the model (table 8.2). The management transition group consists of three transition types: forest harvest, forest-to-tree plantation conversion, and treeplantation harvest. Due to a lack of contemporary information, transition targets for forest and tree-plantation management were set to zero under the BAU scenario.

Compared to other transition types, wildland fire transitions were handled uniquely in the model using an approach that initiated wildland fire ignitions and then spread into adjacent pixels. The wildland fire size distribution and transition probabilities were based on the time series of burned area and severity mapped from Landsat imagery between 2002 and 2011 using the Monitoring Trends in Burn Severity (MTBS) project's mapping protocol for fires larger than $0.4 \mathrm{~km}^{2}$ (Eidenshink, 2007), as described in Hawbaker and others (this volume, chap. 5). For each timestep and Monte Carlo simulation, the number and size of fires was randomly drawn from the baseline fire size distribution (table 8.3). Fires

Table 8.2. Transition targets and probabilities used in the Land Use and Carbon Scenario Simulator (LUCAS) model for the "business as usual" scenario. [prob, probability]

\begin{tabular}{|c|c|c|c|c|c|c|c|c|}
\hline Transition type & \multicolumn{2}{|c|}{ Moisture zone } & From class & To class & $\begin{array}{c}\text { Mean area } \\
\left(\mathbf{k m}^{2}\right)\end{array}$ & $\begin{array}{c}\text { Min area } \\
\left(\mathrm{km}^{2}\right)\end{array}$ & $\begin{array}{c}\text { Max area } \\
\left(\mathrm{km}^{2}\right)\end{array}$ & $\begin{array}{c}\text { Distribution } \\
\text { type }\end{array}$ \\
\hline Agricultural contraction & \multicolumn{2}{|l|}{ N/A } & Agriculture & Forest, shrubland, grassland & --- & 25 & 65 & Uniform \\
\hline \multirow[t]{2}{*}{ Moisture zone change } & Dry & Mesic & All & All & 8 & --- & -- & --- \\
\hline & Wet & Mesic & & & 3 & --- & --- & --- \\
\hline Transition type & \multicolumn{2}{|c|}{ Moisture zone } & From class & To class & $\begin{array}{c}\text { Mean } \\
\text { prob }\end{array}$ & $\begin{array}{l}\text { Min } \\
\text { prob }\end{array}$ & $\begin{array}{l}\text { Max } \\
\text { prob }\end{array}$ & $\begin{array}{c}\text { Distribution } \\
\text { type }\end{array}$ \\
\hline Shrub encroachment & \multicolumn{2}{|c|}{ Dry, mesic, wet } & Grassland & Shrubland & --- & 0.006 & 0.0327 & Uniform \\
\hline
\end{tabular}

Table 8.3. Transition probabilities for the wildland fire transition type for different moisture zones, state classes, and years.

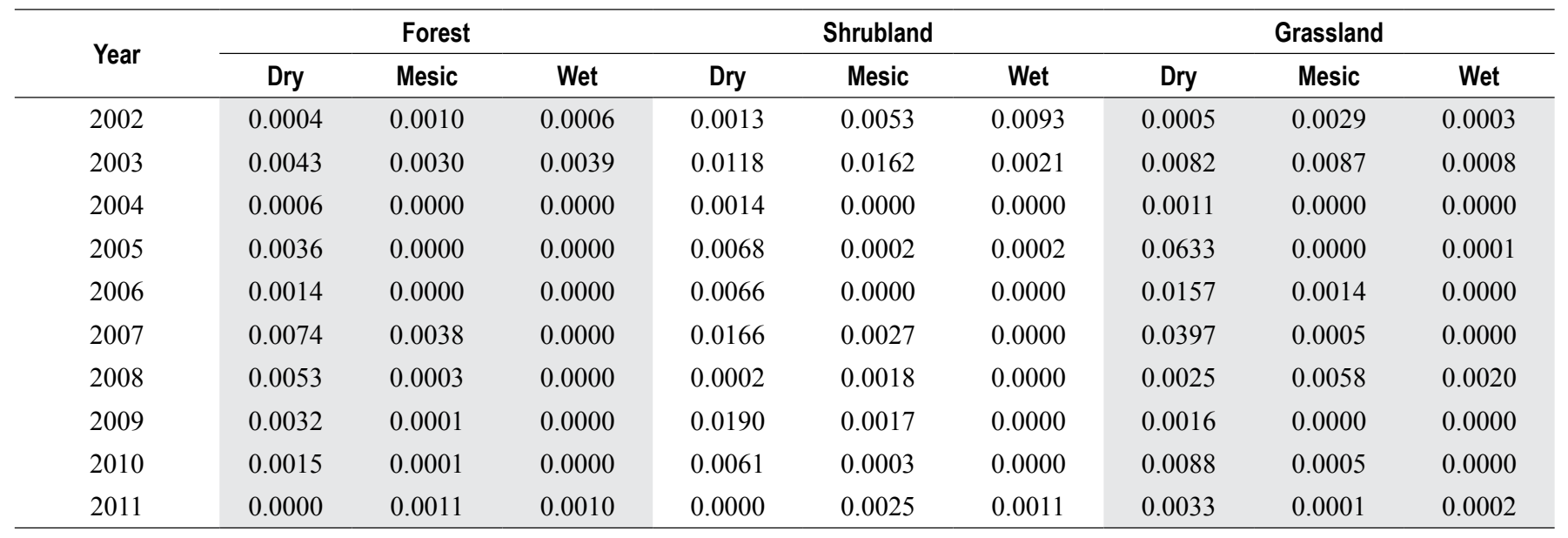


were initiated at randomly selected ignition points in burnable state classes (forest, shrubland, and grassland) and weighted by baseline burn probabilities for each state class (for example, grasslands had higher ignition probabilities than forests). Once initiated, fires would spread to adjacent pixels based on their transition multipliers (table 8.4) until the fire reached its randomly selected fire size or there were no more burnable pixels left to spread into. Fire spread was not adjusted to account for effects of slope or wind speed (daily weather were not used as inputs) as has been done with some other state-and-transition models (STSMs) (Liu and others, 2015); however, this had little effect on the simulated shapes and sizes of fires given the generally small size of fires in Hawai' $i$ and the $1 \times 1-\mathrm{km}$ resolution of cells used in the model. As pixels were burned, they were randomly assigned a burn-severity category based on an additional set of transition multipliers (historical proportions for each state class and burn-severity class; table 8.5 ). The burn-probability category determined the state-class transition of a pixel (table 8.1). For both ignitions and spread, year-to-year variability was introduced by randomly selecting burn probabilities from one of the baseline years (2002-2011; table 8.4). Using this approach, future potential changes in the amount of area burned by wildland fires were a function of changes in the area of different burnable state classes.

Transition multipliers were also used to project changes in shrub encroachment; however, little is known about the rates of shrub encroachment in Hawai' $i$ and large uncertainties exists surrounding the rates and pattern of conversion. In the dry and mesic moisture zones, grassland cells that had not experienced fire for 10 years became eligible for shrubland encroachment. For each Monte Carlo simulation, we sampled from a uniform distribution

Table 8.4. Distribution of wildfire sizes (burned area and patch size).

\begin{tabular}{ccc}
\hline $\begin{array}{c}\text { Min area } \\
\left(\mathbf{k m}^{2}\right)\end{array}$ & $\begin{array}{c}\text { Max area } \\
\left(\mathbf{k m}^{2}\right)\end{array}$ & Proportion of events \\
\hline 0 & 1.0 & 0.5843 \\
1.1 & 2.0 & 0.3983 \\
2.1 & 5.0 & 0.1895 \\
5.1 & 10.0 & 0.0885 \\
10.1 & 25.0 & 0.0243 \\
25.1 & 50.0 & 0.0073 \\
\hline 50.1 & 75.0 & 0.0033 \\
75.1 & 100.0 & 0.0018 \\
\hline 100.1 & 200.0 & 0.0004 \\
\hline
\end{tabular}

of values representing a 0.95 cumulative transition probability for 50 and 500 years without fire, resulting in annual transition probabilities ranging from 0.0327 to 0.006 (table 8.2).

\subsubsection{Spatial Multipliers}

Within the model, two types of spatial constraints were used to influence the pattern of LULC transitions. First, adjacency rules were established to drive transitions into cells immediately adjacent to existing cells classified in the "to" state class. For example, transitions into development (urbanization pathway) could only occur in cells immediately adjacent to existing developed cells. Second, spatial layers representing land ownership, protected lands, and land-use zoning were used to prohibit or limit changes from certain cells.

For the agricultural expansion, agricultural contraction, urbanization, and moisture-zone transitions, adjacency settings were established where candidate cells for each transition type were assigned a cell-based probability that was a linear function of the eight neighboring cells classified in the "to" class. The effect of this parameter setting results in cells with a higher number of neighbors being given a higher spatial multiplier value. Cells with no neighbors were assigned a transition multiplier value of zero, resulting in no possibility of transition. For the shrub encroachment transition, all cells with at least one neighbor were assigned values of one and cells with no neighbors were assigned a value of zero. The process for calculating adjacency probabilities was updated every 5 years for all transitions.

In addition to adjacency rules described above, a set of spatial maps was developed to further refine the location of modeled transitions. For the agricultural expansion pathway, a map of areas prioritized for agricultural production was obtained from the State of Hawai'i Office of Planning (http:// planning.hawaii.gov/gis/download-gis-data/). Cells classified as "zoned for agriculture" were assigned a spatial multiplier value of one; all other cells were assigned a value of zero (fig. 8.2). The same dataset was used to restrict urbanization where cells classified as "urban" were assigned a value of one. So as not to entirely limit urbanization from occurring in cells outside this zoned area, all other cells were assigned a spatial multiplier value of 0.5 . Lastly, for both transitions, cells designated for conservation were assigned a value of zero, and were not allowed to experience a land-use conversion into agriculture or development (fig. 8.2).

Table 8.5. Burn-severity probabilities for different moisture zones and state classes.

\begin{tabular}{|c|c|c|c|c|c|c|c|c|c|}
\hline Moisture zone & \multicolumn{3}{|c|}{ Forest } & \multicolumn{3}{|c|}{ Shrubland } & \multicolumn{3}{|c|}{ Grassland } \\
\hline High & 0.0087 & 0.1207 & 0.0052 & 0.0047 & 0.0637 & 0.0348 & 0.0150 & 0.0109 & 0.0056 \\
\hline Low & 0.9086 & 0.5469 & 0.6496 & 0.8629 & 0.5454 & 0.2750 & 0.8801 & 0.8271 & 0.7178 \\
\hline
\end{tabular}




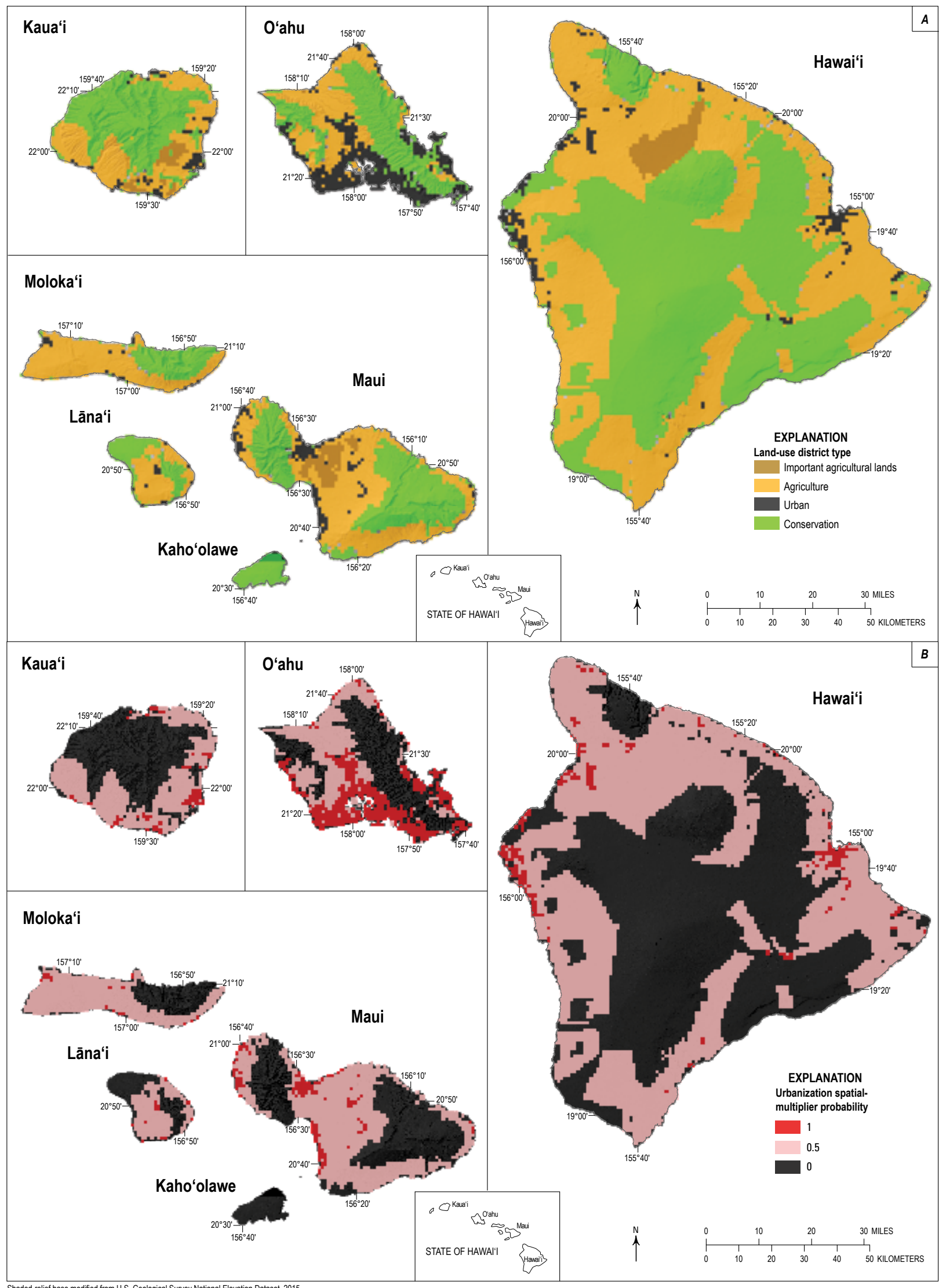

Figure 8.2. Maps showing State of Hawai'i Land-Use Districts which were used to generate spatial multiplier probabilities. $A$, Original source data. $B$, Urbanization spatial multiplier. $C$, Agricultural-expansion spatial multiplier (facing page). 


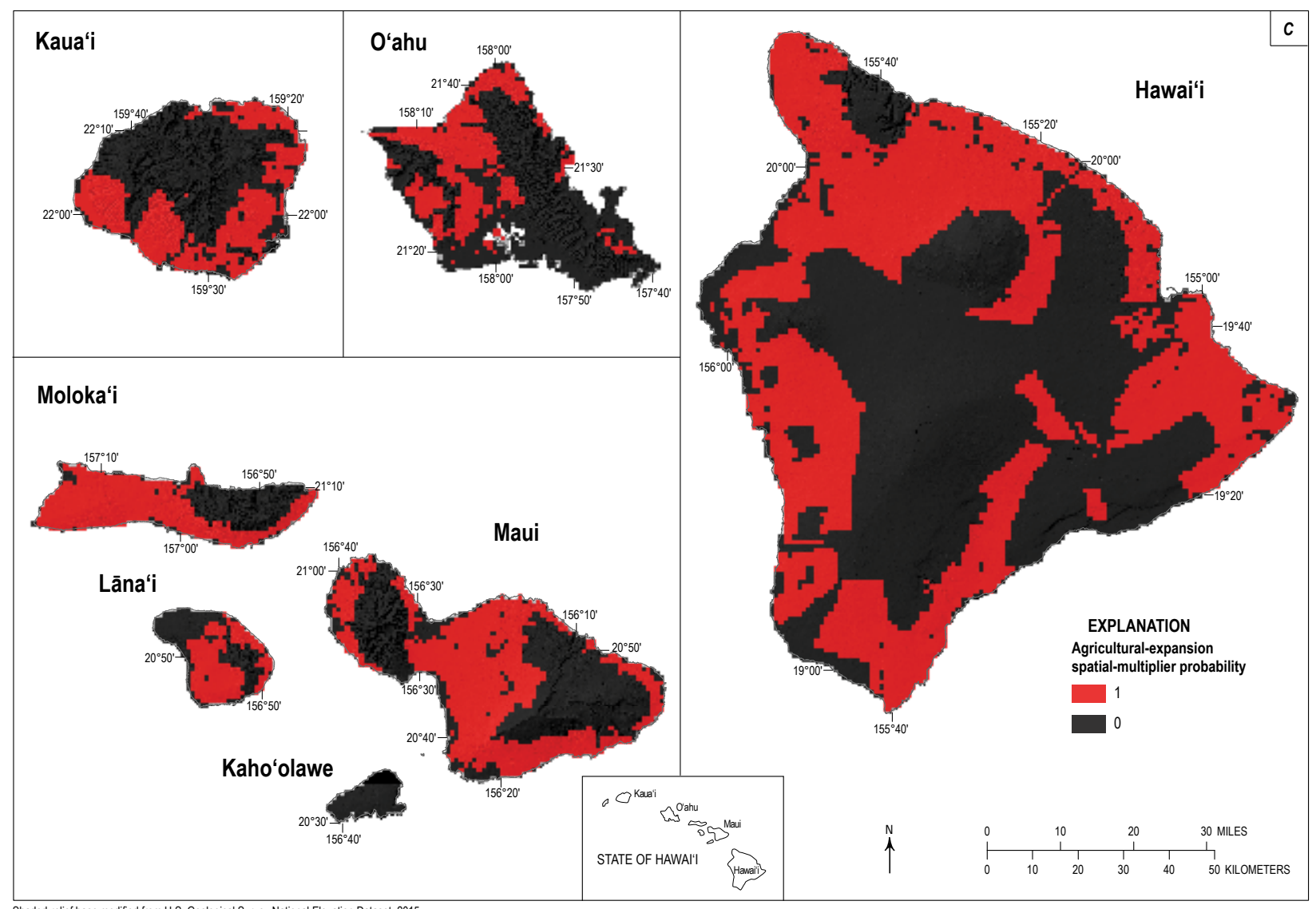

Figure 8.2.-Continued

Agricultural contraction was allowed to occur on all lands with the exception of "high priority agricultural lands" as classified by State of Hawai'i Office of Planning (http:// planning.hawaii.gov/gis/download-gis-data/); all cells within these areas were given a value of zero, whereas all other cells were allowed to transition out of agriculture. These areas were generally confined to Waimea on the Island of Hawai' $i$, Maui's Central Valley, and near Lihue on Kaua'i (fig. 8.2).

Changes in the spatial extent of moisture zones were limited to areas projected in Fortini and others (this volume, chap. 3). Maps of changes between dry, mesic, and wet moisture zones were obtained for the 2000-2100 period; cells where changes in moisture zone were projected to occur were assigned a value of one, whereas all other cells were assigned a value of zero.

\subsubsection{Model Initialization}

Each cell was assigned to 1 of 210 unique state classes based on the spatial intersection of moisture zones (Fortini and others, this volume, chap. 3), islands, and a map of LULC (Jacobi and others, this volume, chap. 2). The moisture-zone map was resampled to $1-\mathrm{km}$ resolution using a nearestneighbor algorithm (fig. 8.1). To estimate the initial LULC for each cell, the carbon assessment for Hawai' $i(\mathrm{CAH})$ land-cover map was first reclassified from its original 27 classes to match the classification scheme described in section 8.3.1. Next, the reclassified LULC map was resampled from its original $30-\mathrm{m}$ resolution to $1-\mathrm{km}$ cells using a majority algorithm (fig. 8.1). The origin and projection of both the moisture-zone and LULC map were set to match each other using a Universal Transverse Mercator Projection (UTM zone 3, NAD83 datum). Lastly, a map of the State of Hawai'i was obtained from the State of Hawai'i Office of Planning (http:// planning.hawaii.gov/gis/download-gis-data/) and resampled to match the spatial parameters of the other two maps. The three spatial maps were then overlaid and each cell was assigned to one of the 210 unique combinations of moisture zone, island, and LULC class, resulting in the initial state-class map. The same initial conditions were used for all Monte Carlo simulations.

Age was tracked as a state-class variable for forests, shrublands, grasslands, and tree plantations; however, there are no known data describing the present-day age distribution of Hawai' $i$ ecosystems. For forests, shrublands, and grasslands, age was randomly assigned to each cell from a uniform distribution between 0 and 300. For tree plantations, we assumed a uniform distribution of ages between 0 and 50 . Initialization of time-since-transition was tracked for wildfire for the grasslands class. To initialize TST we assumed a uniform distribution of values between 0 and the average firereturn interval for grasslands within each moisture zone - 69 years for dry grasslands and 502 years for mesic grasslands. 


\subsubsection{Carbon Accounting Submodel}

The carbon accounting submodel was designed to track the stocks and fluxes of carbon over time resulting from natural ecological processes (for example, growth or mortality) and changes in LULC, which can be functions of a change in climate (moisture-zone shifts), wildfire, and other anthropogenic drivers. The methods used to parameterize and run the integrated carbon submodel are based on Sleeter and others (2015), and follow a general SF or systems-dynamics approach and a tier 3 approach to carbon accounting, which requires locally specific, high-quality input data, recommended by the Intergovernmental Panel on Climate Change (IPCC, 2006). We use the term "flow pathways" to define the movement of carbon from one stock to another (for example, carbon flux). Flow pathways can occur automatically (for example, growth of biomass), or be related to transitions modeled in the STSM (for example, wildfire resulting in the flux of carbon from biomass to the atmosphere or deadwood pools). The SF model tracks the stock and flow of carbon across forest, grassland, shrubland, and tree-plantation state-class types. For all other state classes we assume carbon stocks are stable.

The SF submodel tracks carbon stored in the following pools: living biomass, litter, standing deadwood, downed deadwood, and soil. In addition, the model tracks carbon moved to the atmosphere by emissions, soil leaching from aquatic systems, and harvested wood products. Carbon is tracked on an annual timestep for each Monte Carlo simulation in forest, shrubland, grassland, and tree-plantation classes. Flow pathways include growth, litterfall, humification, emission, mortality, and harvest (table 8.6). Depending upon the flow type, the rate at which carbon is moved from one pool to another may vary based on state-class type, age, timestep, and (or) Monte Carlo simulation. Furthermore, flows of carbon between stock types are divided between "automatic" and "event-based" flows, where automatic flows occur for all cells in all timesteps, and eventbased flows only apply to cells that experience a state transition (Sleeter and others, 2015). For each timestep and Monte Carlo simulation, the order of flows was implemented at random.

We used the IBIS model to generate automatic flow rates for forest, shrubland, and grassland state classes. IBIS (Foley and others, 1996; Kucharik and others, 2000) is a modeling framework that follows basic rules of physics, plant physiology, and biogeochemistry. The original model combined features of a mechanistic model of canopy photosynthesis (Farquhar and others, 1980), a semi-mechanistic model of stomatal conductance (Ball and others, 1987), an algorithm on phenology (Botta and others, 2000), and several soil biogeochemical models (Parton and others, 1987, 1993; Verberne and others, 1990) in a single application. IBIS has the ability to simulate major land-surface processes, canopy physiology, vegetation phenology, long-term vegetation dynamics, ecosystem production, and carbon cycling.

The approach to developing automatic flow rates was based on methods developed by Sleeter and others (2015) which link the IBIS model to the SF submodel described here. A calibration simulation was run in IBIS using "cold start" procedures, which supply the SF submodel with automatic flow pathway rates. The IBIS cold-start simulation starts with bare ground for all cells and then simulates the growth of vegetation in response to average historical climate conditions for the region. To calibrate IBIS to local conditions we used estimates of net primary production (NPP) derived from gross primary production (GPP) from Selmants and others (this volume, chap. 6) and aboveground living biomass described in Selmants and others (this volume, chap. 6). A series of IBIS model simulations were run until NPP and living biomass pools were stabilized at levels similar to observed conditions. Carbon flux rates from IBIS (in other words, automatic flows) were generated on annual timesteps and aggregated to the following age categories for the SF submodel: $0-10$ years, $10-20$ years, $20-50$ years, $50-100$ years, and greater than 100 years old. All flow pathways were non-time varying, meaning no assumption was made as to how carbon fluxes may change under future conditions. The result of this assumption is, for example, that the rate of forest litterfall for a 50-year-old forest is not changed in future projection years.

The growth flow pathway moves carbon from the atmosphere to living biomass stock and is expressed as NPP. NPP was derived from MODIS GPP estimates described in Selmants and others (this volume, chap. 6). MODIS estimates of NPP are typically derived by modeling components of autotrophic respiration $\left(R_{\mathrm{a}}\right)$ and then subtracting $R_{\mathrm{a}}$ from GPP to yield estimates of NPP. However, the BIOME-BGC model of $R_{\mathrm{a}}$ requires the MOD15 leaf area index (LAI) product as an input, which is in part based on the MOD12Q1 land-cover product, and it was not possible to substitute our modified land-cover map into the MOD15 estimate of LAI. Here, NPP was estimated by calculating carbon-use efficiency (CUE; the quotient of NPP divided by GPP) for all pixels from the "off the shelf" 1-km-resolution MOD17 product with land-cover classes that corresponded with those of the land-cover map described in Jacobi and others (this volume, chap. 2), for the period 2002-2010. We then calculated the median CUE for each land-cover type used in this report (table 8.7) and multiplied the modified MOD17 estimates of GPP from Selmants and others (this volume, chap. 6) by these land-cover-specific CUE values to yield a statewide 500-m-resolution layer of terrestrial NPP. The statewide MODIS-derived estimates of NPP were used to calibrate the IBIS model simulation. Within the LUCAS SF submodel, the growth flow pathway was based on IBIS estimates of NPP for each state class and moisture zone combination. IBIS NPP estimates include the annual growth of biomass in aboveground and belowground vegetation, including roots, leaves, and wood. Owing to a lack of future projections of NPP under alternative climate scenarios, annual projections of growth for the SF submodel were derived from the IBIS-modeled mean NPP estimate and allowed to vary by \pm 5 percent annually.

Seven flow types (growth, litterfall, humification, mortality, deadfall, emissions, and leaching) were specified in the model for each combination of moisture zone, state class, and age class. The tree-plantation class was assigned flow rates from the wet forest state-class type. Growth is the annual rate of carbon accumulation in living biomass expressed as NPP. Litterfall is an 
Table 8.6. Carbon-flow types used within the Land Use and Carbon Scenario Simulator (LUCAS) model.

[HWP, harvested wood products]

\begin{tabular}{|c|c|c|c|c|}
\hline Carbon-flow type & State class type & Flow pathway type & From stock & To stock \\
\hline Growth & All & Automatic & Atmosphere & Living biomass \\
\hline Litterfall & $\begin{array}{l}\text { All } \\
\text { Forest } \\
\text { Shrubland } \\
\text { Plantation }\end{array}$ & $\begin{array}{l}\text { Automatic } \\
\text { Automatic }\end{array}$ & $\begin{array}{l}\text { Living biomass } \\
\text { Down deadwood }\end{array}$ & Litter \\
\hline Humification & All & Automatic & Litter & Soil \\
\hline Mortality & $\begin{array}{l}\text { Forest } \\
\text { Shrubland } \\
\text { Plantation }\end{array}$ & Both & Living biomass & Standing deadwood \\
\hline Deadfall & $\begin{array}{l}\text { Forest } \\
\text { Shrubland } \\
\text { Plantation }\end{array}$ & Automatic & Standing deadwood & Down deadwood \\
\hline Emission & $\begin{array}{l}\text { All } \\
\text { All } \\
\text { All } \\
\text { HWP }\end{array}$ & $\begin{array}{l}\text { Both } \\
\text { Automatic }\end{array}$ & $\begin{array}{l}\text { Living biomass } \\
\text { Litter } \\
\text { Soil } \\
\text { Atmosphere }\end{array}$ & Atmosphere \\
\hline Harvest & $\begin{array}{l}\text { Forest } \\
\text { Plantation }\end{array}$ & Event & Living biomass & HWP \\
\hline
\end{tabular}

annual flux rate that includes leaf and root biomass moving from the living biomass to the litter stock. Humification is the annual decomposition rate of organic material from litter to soil organic matter. Mortality is an annual rate resulting from natural death of vegetation that also includes mortality resulting from land-use activities such as urbanization, wildfire, and harvest. Deadfall is the annual rate of transfer of carbon between standing and downed deadwood stocks. Emissions include the annual rate of respiration from litter and soil pools (heterotrophic respiration $\left[R_{\mathrm{h}}\right]$ ) as well as emissions resulting from land-use change and disturbances. Leaching is the annual rate of carbon flux from the soil pool to the aquatic pool. Harvest is the rate of transfer of carbon from the living biomass pool to harvested wood products as a result of land use and land-use change.

Event-based flows are associated with transition pathways from the STSM. When the STSM applies a transition for a given cell the SF submodel applies a predefined set of additional flows to move carbon between stocks. In this model, event-based flows are specified for urbanization, agricultural expansion, and forest and tree-plantation harvest and associated with emission and harvest-flow types. When one of these transitions occurs on a cell, one or more flow pathways are invoked to move carbon between various stocks.

Carbon initial conditions were specified for the livingbiomass, soil, litter, standing-deadwood, and downed-deadwood stocks. The model was initialized to match, as closely as possible, estimates of living biomass for each state-class type, based on known reference data described in Hawbaker and others (this volume, chap. 5) and Selmants and others (this volume, chap. 6). Estimates of soil organic carbon were derived from the U.S. Department of Agriculture gridded Soil Survey Geographic (gSSURGO) Database (Soil Survey Staff, 2015; see Selmants and others, this volume, chap. 6). For each combination of state class and moisture zone a mean carbon estimate was derived from the gSSURGO map to initialize the SF submodel. IBIS was used to derive initial estimates for living-biomass, litter, and both standing- and downeddeadwood stocks and calibrated using carbon stock data from Hawbaker and others (this volume, chap. 5). For living biomass on forests and tree plantations, IBIS estimates (which include aboveground and belowground carbon) were compared to estimates of aboveground biomass based on the light detection and ranging (lidar)-derived reference map and the estimates of belowground biomass based on the power law equation described in Selmants and others (this volume, chap. 6).

\subsubsection{Simulation Experiments}

The model described above was used to project changes in ecosystem carbon under a BAU scenario where landscape changes were a function of the transition pathways and parameters described in section 8.3.3. For the BAU scenario we simulated changes in LULC and carbon during a 60-year projection period spanning the years 2001 through 2061 with

Table 8.7. Estimated carbon-use efficiency for MOD12Q1 biomes used to calculate net primary production.

[Based on the quotient of net primary production divided by gross primary production from 1-km-resolution MOD17 product. CUE, carbon-use efficiency]

\begin{tabular}{lc}
\hline \multicolumn{1}{c}{ MOD12Q1 biome } & Median CUE \\
\hline Broadleaf evergreen forest & 0.495 \\
Woody savanna & 0.475 \\
Closed shrub & 0.545 \\
Open shrub & 0.484 \\
Grassland & 0.485 \\
\hline
\end{tabular}


the first 10 years being used for model spin-up. During this spin-up period the landscape was fixed and no changes were allowed to occur. Monte Carlo replications of the model were run 100 times to reflect uncertainties in the projection of various state-class transitions. To evaluate impacts of major controlling processes on ecosystem carbon we conducted a series of sensitivity tests to analyze the impact of specific model parameters. Twenty Monte Carlo iterations were run for each of these scenarios.

\subsection{Results and Discussion}

\subsubsection{Projections of Land-Use and Land-Cover Composition and Transitions}

Four state classes composed 86.3 percent of Hawai'i's land area in 2011: forest (33.8 percent), barren (19.1 percent), grassland (17.0 percent), and shrubland (16.4 percent). Agriculture (5.7 percent) and developed (6.2 percent) land uses accounted for most of the remaining land area. By 2061, the area collectively covered by the four main land-cover classes was projected to decrease slightly to 84.3 percent, however, composition among the four classes changed considerably (fig. 8.4). Forest area decreased to 32.7 percent and barren lands decreased to 18.6 percent of the State's land area. The most significant changes were between shrubland and grassland composition; grassland area decreased to 10.2 percent, whereas shrubland increased to 22.8 percent. Total land in agriculture decreased sharply to less than 1.0 percent of the State's area, whereas developed land nearly doubled to 12.9 percent.

The agriculture class was projected to experience the largest loss of any state class, decreasing to less than $180 \mathrm{~km}^{2}$ by 2061 , a net loss of 81.3 percent (fig. 8.3). Nearly all losses in agriculture were through conversion to forests, shrublands, or grasslands; losses to development averaged approximately $2 \mathrm{~km}^{2} / \mathrm{yr}$ (fig. 8.4). For the first 30 years of the projection, agricultural contraction $\left(\sim 45 \mathrm{~km}^{2} / \mathrm{yr}\right)$ occurred at a rate more than two times greater than agricultural expansion $\left(\sim 20 \mathrm{~km}^{2} /\right.$ yr) (fig. 8.4). However, by 2045, the rate of contraction was about equal to the expansion rate. Figure $8.5 \mathrm{~A}$ shows the spatial location of where agricultural expansion was most common.

Under the BAU scenario, developed lands were projected to increase by an average of $1,094 \mathrm{~km}^{2}$ during the 50 -year projection period, representing an increase of 107.7 percent over initial conditions (fig. 8.3). By 2061, development was projected to account for between 12.4 and 13.5 percent of the state land area. State classes converted to development were forests $\left(9 \mathrm{~km}^{2} / \mathrm{yr}\right)$, grasslands $\left(5 \mathrm{~km}^{2} / \mathrm{yr}\right)$, and shrublands $\left(5 \mathrm{~km}^{2} / \mathrm{yr}\right)$; barren lands accounted for $2 \mathrm{~km}^{2} / \mathrm{yr}$. For the first 20 years of the projection period, agricultural lands were also contributors to urbanization; however, as agriculture is projected to decrease in area over time, its urbanization becomes minimal. Figure $8.5 B$ shows the average annual transition probability for urbanization across 50 years and 100 Monte Carlo iterations.

The major driver of change within the three forest classes was the projected change in moisture-zone composition (see Fortini and others, this volume, chap. 3) (fig. 8.4). Overall, forest area was projected to decrease by 3.4 percent $\left(170 \mathrm{~km}^{2}\right)$ compared to 2011 ; however, change was not consistent across moisture zones. Dry forests were projected to increase 33.4 percent $\left(274 \mathrm{~km}^{2}\right)$, mesic forests were projected to decrease 29.6 percent $\left(1,760 \mathrm{~km}^{2}\right)$, and wet forests were projected to increase 1.2 percent $\left(11 \mathrm{~km}^{2}\right)$ by 2061 (fig. 8.6).

Woody encroachment was the only change between vegetation types considered in the model, which resulted in changes from grasslands to shrublands. Across the dry and mesic moisture zones we estimated an average of $1,325 \mathrm{~km}^{2}$ of grasslands would be converted to shrublands during the 50 -year projection. However, there was considerable uncertainty in this projection with estimates ranging from a low of $338 \mathrm{~km}^{2}$ to a high of $2,265 \mathrm{~km}^{2}$ (fig. 8.4). Shrublands were projected to increase by 39.2 percent $\left(1,058 \mathrm{~km}^{2}\right)$, which was ubiquitous across all three moisture zones: dry shrublands increased from 1,422 to $2,096 \mathrm{~km}^{2}$, mesic shrublands increased from 897 to $1,223 \mathrm{~km}^{2}$, and wet shrublands increased from 382 to $440 \mathrm{~km}^{2}$ (fig. 8.6). The area of grasslands decreased in both the dry and mesic moisture zones (from 1,492 to $823 \mathrm{~km}^{2}$ and from 1,052 to $512 \mathrm{~km}^{2}$, respectively) and remained relatively stable in the wet moisture zone (fig. 8.6).

Across all state classes and moisture zones, wildfire was projected to burn an average of $41 \mathrm{~km}^{2} / \mathrm{yr}$ and a total of 2,047 $\mathrm{km}^{2}$ by 2061 (fig. 8.4). Grasslands accounted for 41 percent of all wildfire projection, whereas shrublands accounted for 42 percent and forests accounted for 17 percent. Fire was projected to be most common in the dry moisture zone (average of $31 \mathrm{~km}^{2} / \mathrm{yr}$ ), accounting for 6 percent of the annual area burned. The mesic moisture zone accounted for 17 percent $\left(7 \mathrm{~km}^{2} / \mathrm{yr}\right)$, whereas the wet moisture zone accounted for 6 percent $\left(3 \mathrm{~km}^{2} / \mathrm{yr}\right)$. Low-severity fire accounted for 81 percent of all projected fire $\left(33 \mathrm{~km}^{2} / \mathrm{yr}\right)$, whereas mediumseverity fire accounted for 17 percent $\left(7 \mathrm{~km}^{2} / \mathrm{yr}\right)$. Highseverity fires accounted for 2 percent of all fire $\left(<1 \mathrm{~km}^{2} / \mathrm{yr}\right)$. The projected annual rates of fire across state classes, moisture zones, and severity classes are shown in figure 8.7.

\subsubsection{Projected Change in Total Ecosystem Carbon Storage}

Carbon fluxes were modeled for the seven main Hawaiian Islands (excluding $\mathrm{Ni}^{i}$ ihau) and for the forest, shrubland, grassland, and tree-plantation state classes. For state and island totals, stock estimates include carbon stored in soils across all state-class types. Overall estimates of living biomass, litter, and deadwood stocks were developed for only the four state classes where fluxes were modeled. 

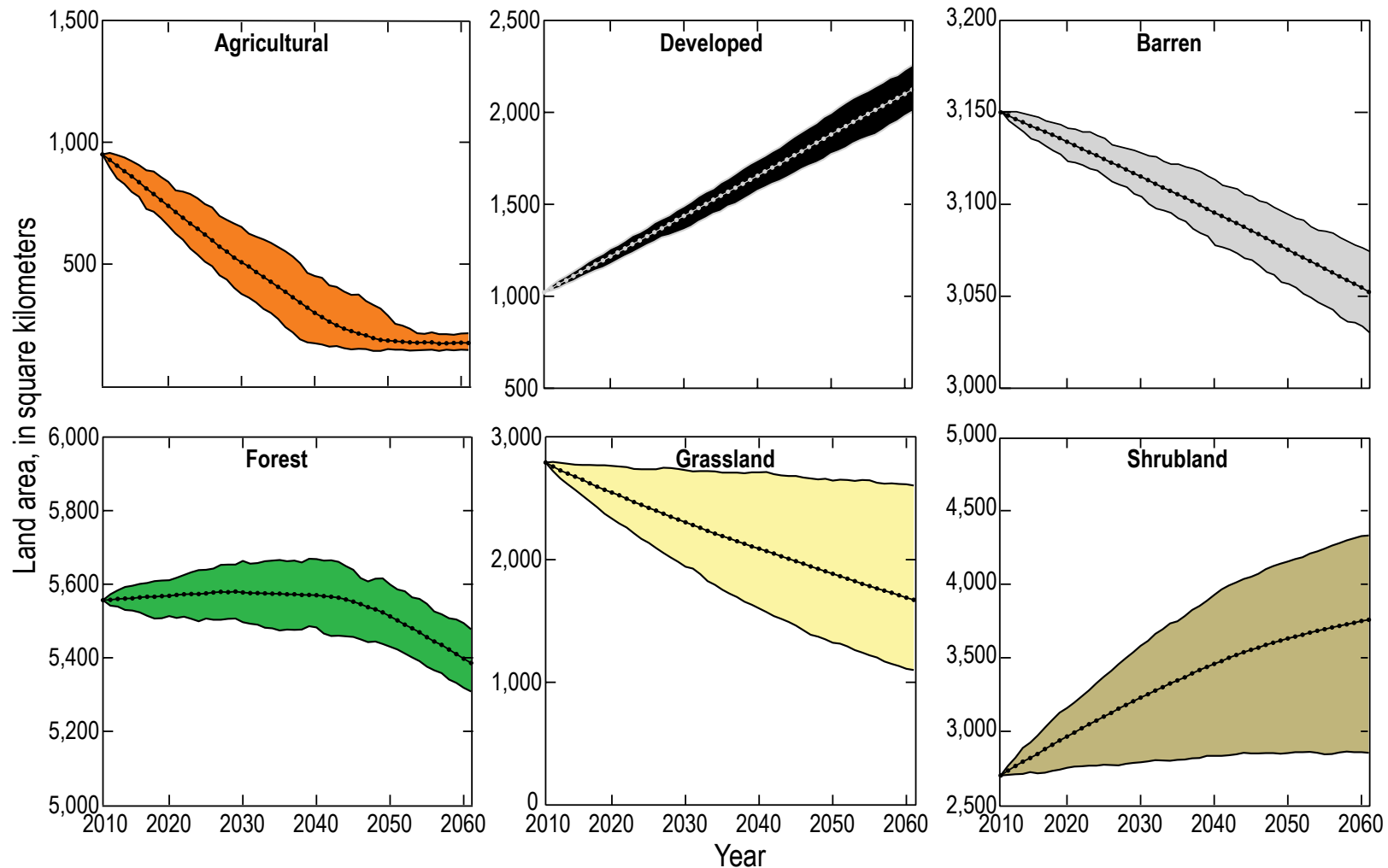

Figure 8.3. Plots of projections of state-class area for the 2011-2061 projection period. The range of values represents the 95-percent confidence interval for each state class across 100 Monte Carlo simulations. Dotted black lines show the mean estimates.
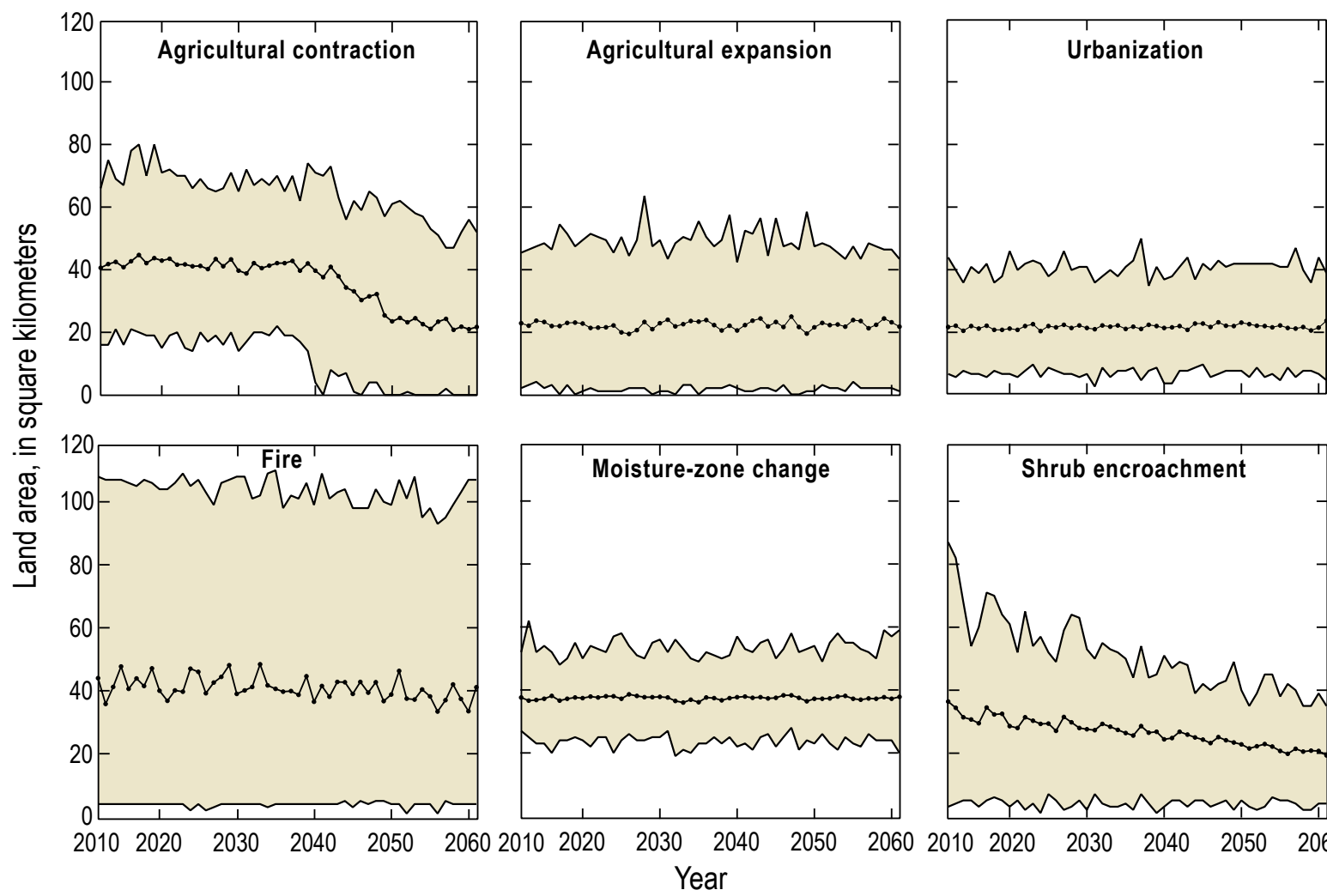

Figure 8.4. Plots of projections of transition groups for the 2012-2061 projection period. The range of values represents the 95-percent confidence interval across 100 Monte Carlo simulations. Dotted black lines show the mean estimates. 


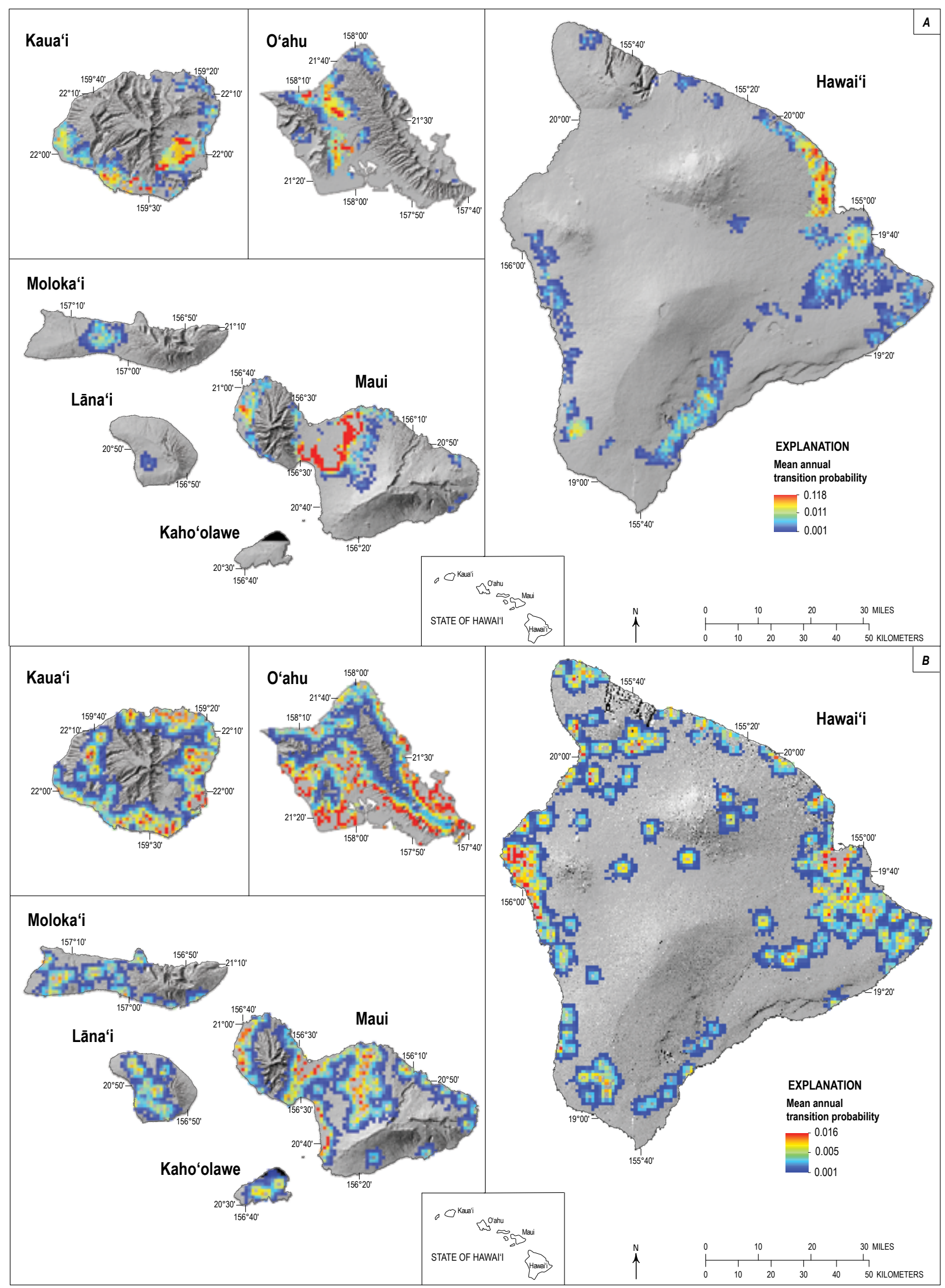

Figure 8.5. Maps showing average annual transition probability across 50 timesteps and 100 Monte Carlo iterations for agricultural expansion $(A)$, urbanization $(B)$, shrub encroachment $(C)$, and wildfire $(D)$ in Hawai'i. 


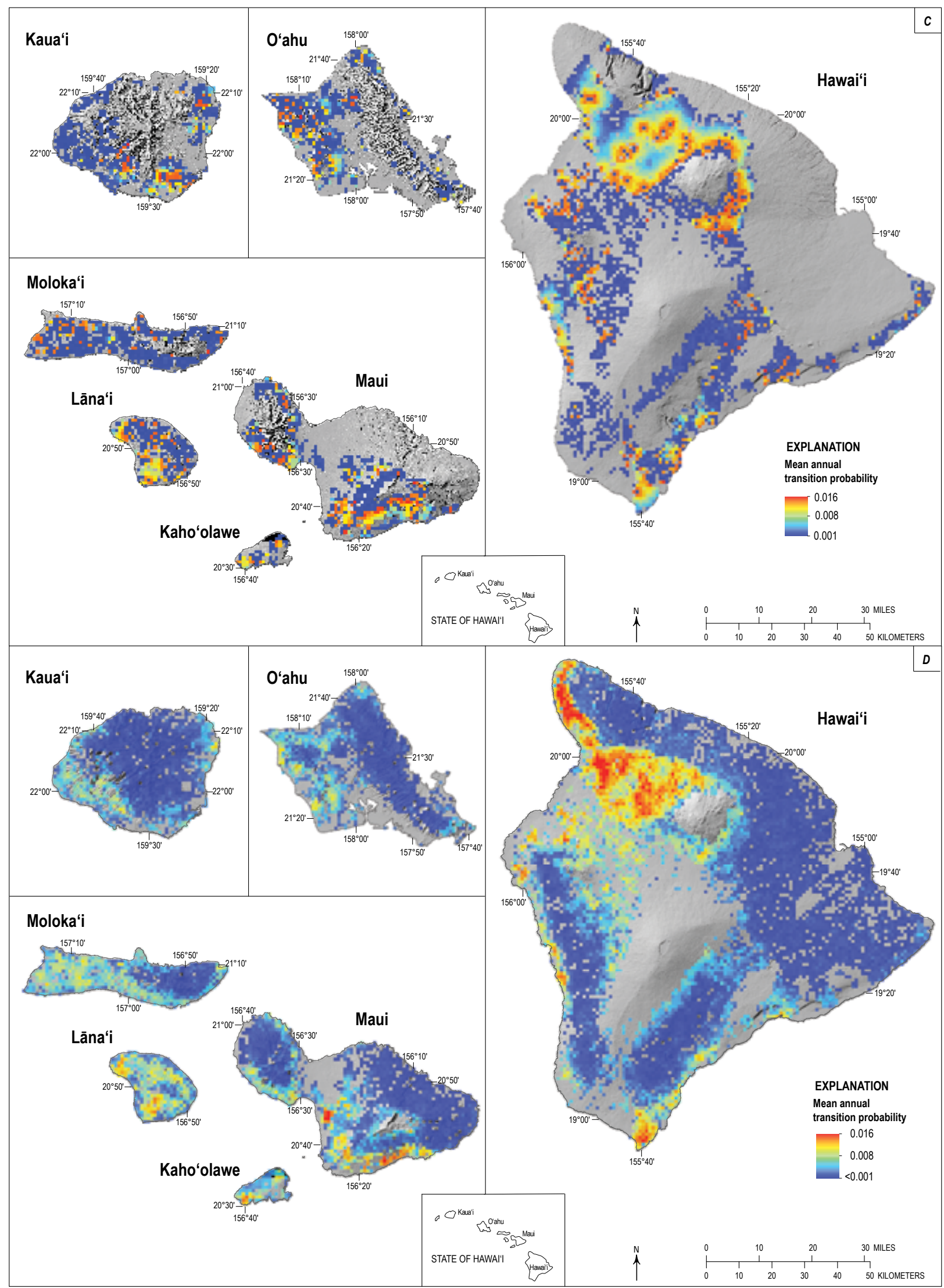

Figure 8.5.-Continued 
Initial IBIS-derived estimates of statewide total ecosystem carbon were about 2 percent lower than statewide estimates described in Selmants and others (this volume, chap. $6)$. Total ecosystem carbon was estimated to increase from $252.9 \mathrm{TgC}$ in 2011 to $267.6 \mathrm{TgC}$ by 2061 , a net increase of 14.7 TgC. Carbon stock density for the state was estimated at $15.5 \mathrm{kgC} / \mathrm{m}^{2}$ and was projected to remain relatively stable throughout the projection period. In 2011, the highest carbon stock densities were found on Kaua'i $\left(19.6 \mathrm{kgC} / \mathrm{m}^{2}\right)$, O'ahu $\left(17.6 \mathrm{kgC} / \mathrm{m}^{2}\right)$, and Maui $\left(16.6 \mathrm{kgC} / \mathrm{m}^{2}\right)$. By 2061, total ecosystem carbon storage was projected to increase on six of the major islands and remain relatively stable on $\mathrm{O}^{\text {'ahu (table }}$ 8.8). Hawai' $i$ Island stored the most carbon (its land area accounts for more than half the State's area) at $153.7 \mathrm{TgC}$ in 2011 and was estimated to increase approximately 7.7 percent by 2061 (165.5 TgC).

Total carbon stored in the dry moisture zone was estimated to increase by 37.5 percent, from $46.1 \mathrm{TgC}$ in 2011 to $63.4 \mathrm{TgC}$ in 2061 . In the mesic moisture zone, total ecosystem carbon was projected to decrease by 17.6 percent, from $89.7 \mathrm{TgC}$ to $73.9 \mathrm{TgC}$. Total ecosystem carbon storage in the wet moisture zone was projected to increase 11.3 percent, from $117.0 \mathrm{TgC}$ to $132.3 \mathrm{TgC}$.

Tables 8.9 and 8.10 show carbon stock estimates for each island and land-cover class, respectively. Similar to results from Selmants and others (this volume, chap. 6), soils
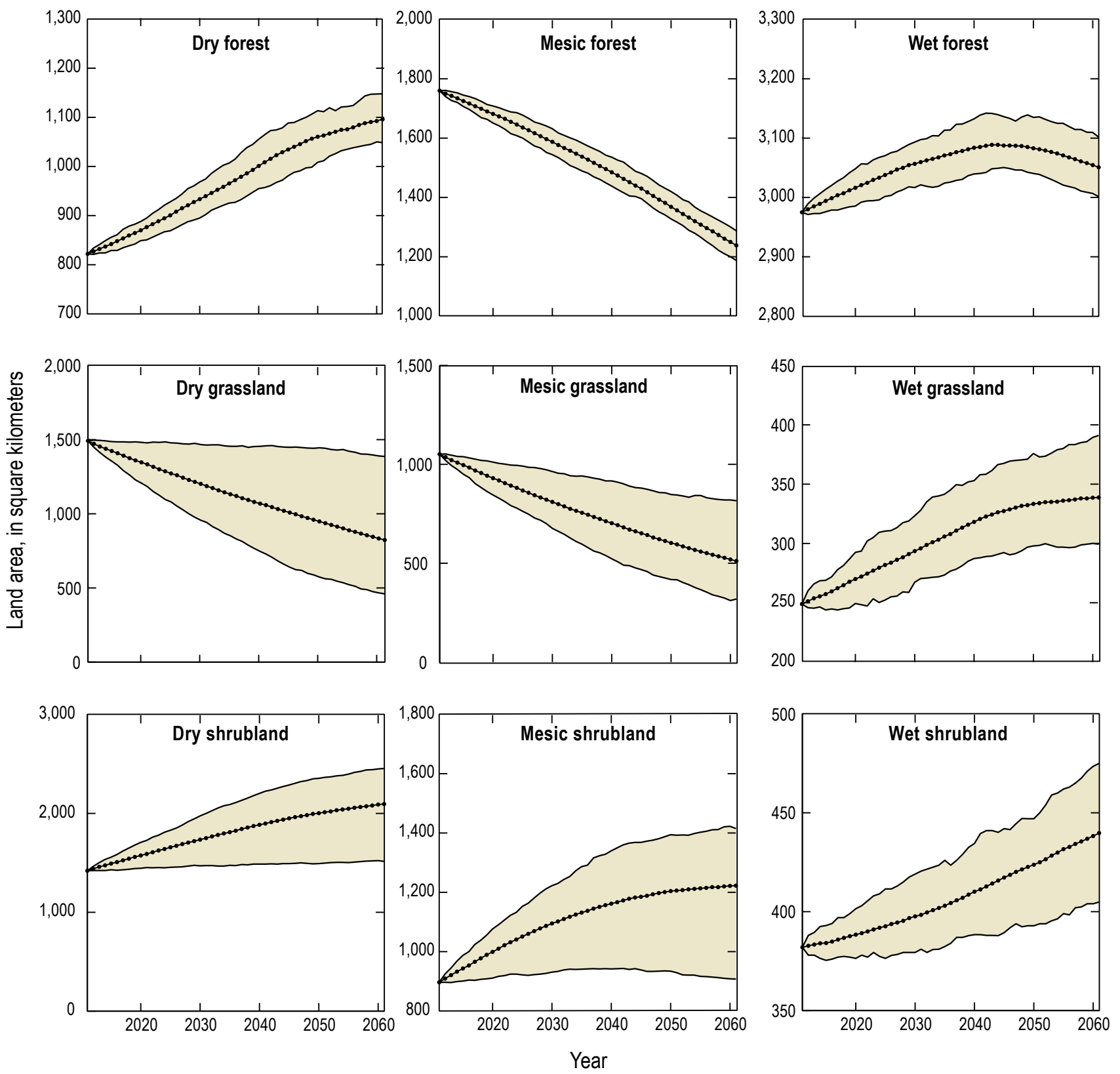

Figure 8.6. Plots of projections of forest, shrubland, and grassland state-class types across the dry, mesic, and wet moisture zones. The range of values represents the 95-percent confidence interval across 100 Monte Carlo simulations. Dotted black lines show the mean estimates. 
accounted for approximately 69 percent of carbon stored in terrestrial ecosystems, living biomass accounted for 24 percent, and litter and deadwood stocks accounted for 8 percent; these proportions remained relatively stable during the 50 -year projection period. Total living biomass was estimated at $52.0 \mathrm{TgC}$ in 2011 and decreased to $51.3 \mathrm{TgC}$ by 2061. Litter and deadwood was estimated at $27.9 \mathrm{TgC}$ in 2011 and increased 5 percent by 2061 to $29.4 \mathrm{TgC}$. Carbon stored in soils, across all state classes, was estimated at $183.6 \mathrm{TgC}$ in 2011 and increased 4 percent by 2061 to $198.0 \mathrm{TgC}$.

In 2011, carbon stored in living biomass was estimated at 52.0 TgC. By 2061, living biomass was estimated to hold $51.3 \mathrm{TgC}$, a decrease of approximately 1.4 percent during the 50-year projection. Across all moisture zones, forests accounted for the vast majority of living biomass carbon (83 percent), whereas tree plantations ( 9 percent), shrublands (7 percent), and grasslands (1 percent) accounted for the remainder. Projections of living biomass carbon across moisture zones varied considerably, owing largely to changes in land use, wildfire, shrub encroachment, and moisture-zone extent. The wet moisture zone remained relatively stable during the projection period, increasing by $2.3 \mathrm{TgC}$ from 2011 levels. Conversely, the mesic zone was projected to experience sharp decreases, from $20.1 \mathrm{TgC}$ in 2011 to $15.5 \mathrm{TgC}$ in 2061 . Living biomass in the dry moisture zone was projected to increase from $2.9 \mathrm{TgC}$ in 2011 to $4.4 \mathrm{TgC}$ in 2061.

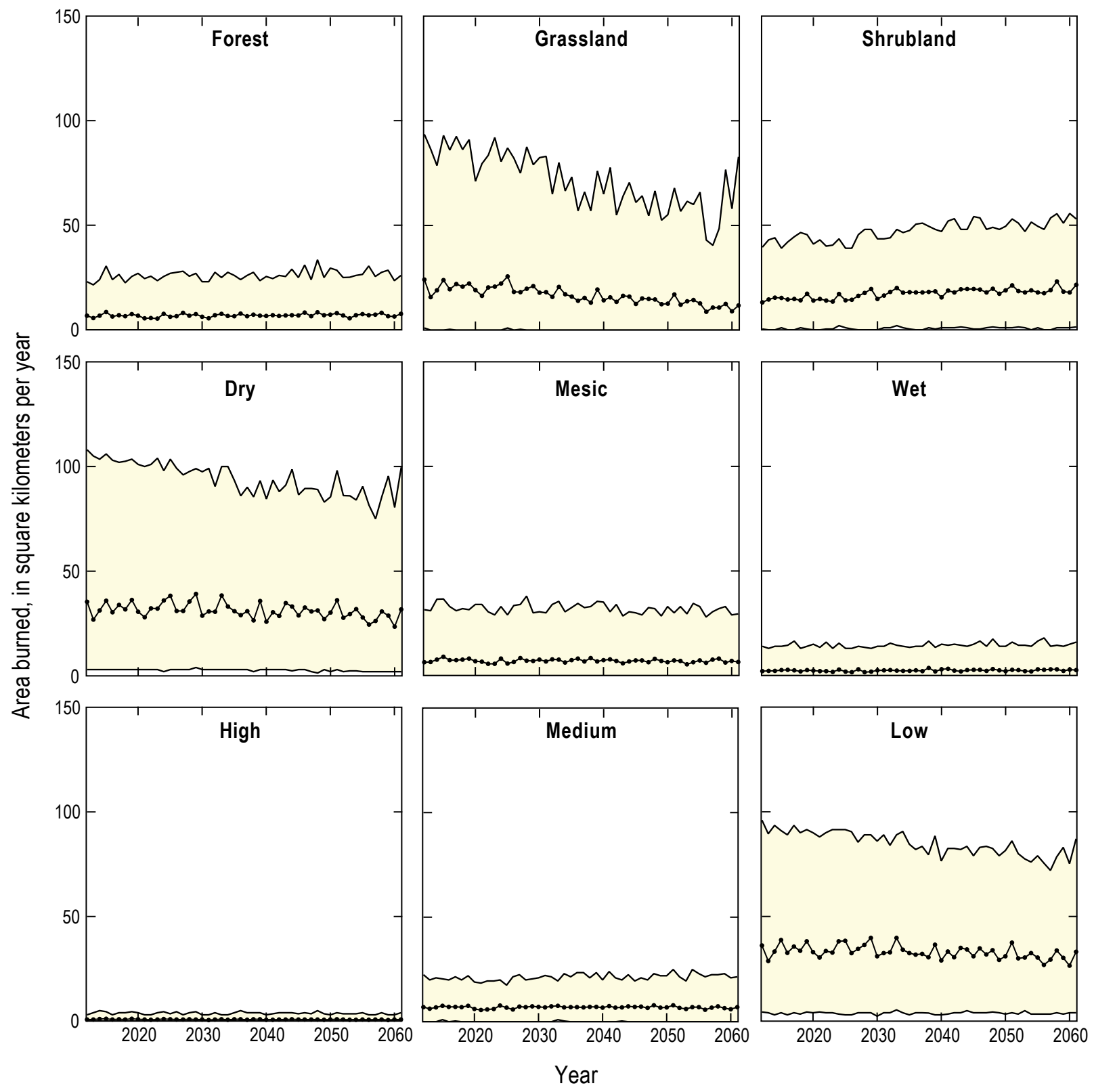

Figure 8.7. Plots of projections of fire by state class, moisture zone, and burn severity during the 2011-2061 projection period. The range of values represents the 95-percent confidence intervals of area burned across 100 Monte Carlo simulations. Dotted black lines show the mean estimates. 
Soil organic carbon was estimated to increase from 183.6 $\mathrm{TgC}$ to $198.0 \mathrm{TgC}$ between 2011 and 2061. However, when considering only carbon stored in the four state-class types where carbon fluxes were modeled (forest, shrubland, grassland, and tree plantation), soil organic carbon was estimated to increase from 151.7 $\mathrm{TgC}$ to $164.8 \mathrm{TgC}$ in 2061 . Wet forests stored more than three times the amount of carbon than any other state-class type (65.7 TgC in 2061), followed by Mesic forests which stored $20.9 \mathrm{TgC}$. Tables 8.9 and 8.10 show the projected change in carbon stocks (by living biomass, soil, and litter and deadwood) between 2011 and 2061 for each island and land-cover class.

\subsubsection{Projected Carbon Fluxes}

Net ecosystem production (NEP) and net ecosystem carbon balance (NECB) are estimated for the State of Hawai' $i$ and for each of the four state-class types considered in this assessment (forest, shrubland, grassland, and tree plantation). NEP is calculated as the sum of annual growth (NPP) minus $R_{\mathrm{h}}$ from litter and soil pools. NECB is calculated as NEP minus emissions from land-use change and disturbance. Due to constant changes in the state-class (and moisture-zone) area, NEP and NECB estimates are presented as totals (in kilotons of carbon [ktC]).

NEP for the State of Hawai' $i$ was estimated at an average annual rate of $0.799 \mathrm{TgC} / \mathrm{yr}\left(49 \mathrm{gC} / \mathrm{m}^{2} / \mathrm{yr}\right)$. When land-use change and disturbances were considered, NECB was estimated at an average annual rate of $0.595 \mathrm{TgC} / \mathrm{yr}\left(36 \mathrm{gC} / \mathrm{m}^{2} / \mathrm{yr}\right)$. Both $\mathrm{NEP}$ and NECB were projected to decrease during the 50 -year projection period indicating the strength of the carbon sink was decreasing. Forest NEP was projected to decrease steadily during the projection period, from approximately $0.754 \mathrm{TgC} / \mathrm{yr}$ in 2015 to $0.549 \mathrm{TgC} / \mathrm{yr}$ in 2061 . Forests in Hawai' $\mathrm{i}$ were projected to be a consistent, yet decreasing net sink of carbon, with a mean NECB estimate of $0.481 \mathrm{TgC} / \mathrm{yr}$. However, the strength of the sink was projected to weaken towards the last half of the simulation period. Shrubland NEP was estimated at $0.091 \mathrm{TgC} / \mathrm{yr}$ and grasslands were estimated at $0.050 \mathrm{TgC} / \mathrm{yr}$. When considering the effects of land-use change and wildfire, shrublands were a net sink of carbon at a rate of $0.066 \mathrm{TgC} / \mathrm{yr}$, whereas grasslands were a weaker net sink at approximately $0.024 \mathrm{TgC} / \mathrm{yr}$. Figure 8.8 shows estimates of NEP and NECB for each combination of state class and moisture zone.

\subsubsection{Carbon Losses From Land-Use Change and Wildfire}

Urbanization of forests, shrublands, and grasslands resulted in an average annual loss of ecosystem carbon storage of $97.9 \mathrm{ktC} / \mathrm{yr}$. Forests accounted for the largest share of carbon loss at an average rate of $79 \mathrm{ktC} / \mathrm{yr}$, whereas shrublands and grasslands accounted for $0.01 \mathrm{TgC} / \mathrm{yr}$ apiece. Expansion of agriculture contributed an additional average annual loss of $0.078 \mathrm{TgC} / \mathrm{yr}$, with $0.057 \mathrm{TgC} / \mathrm{yr}$ from forests, $0.009 \mathrm{TgC} / \mathrm{yr}$ from shrublands, and $0.012 \mathrm{TgC} / \mathrm{yr}$ from grasslands; however this loss was offset owing to higher rates of agricultural contraction. Over the 50-year projection, atmospheric emissions resulting from urbanization and agricultural expansion was estimated at $6.6 \mathrm{TgC}$ with $4.6 \mathrm{TgC}$ coming from forest conversion, $0.9 \mathrm{TgC}$ coming from shrubland conversion, and $1.0 \mathrm{TgC}$ coming from grassland conversion. An additional 2.2 TgC was removed from forest harvest for use in wood products.

Carbon emissions from wildfire averaged $1.4 \mathrm{TgC}$ (0.028 TgC/yr) across the 100 Monte Carlo simulations. However, there was considerable variability, with estimates ranging from $0.001 \mathrm{TgC} / \mathrm{yr}$ to $0.108 \mathrm{TgC} / \mathrm{yr}$. Forest fire emissions accounted for approximately 58 percent of wildfire emissions (0.016 TgC/yr), whereas shrubland fire emissions accounted for approximately 23 percent $(0.006 \mathrm{TgC} / \mathrm{yr})$;

Table 8.8. Current and projected future total ecosystem carbon storage and percent change in storage by island for the State of Hawai'i.

[TgC, teragrams of carbon; Mean, mean of 100 Monte Carlo iterations; Upper, 97.5 percentile; Lower, 2.5 percentile]

\begin{tabular}{|c|c|c|c|c|c|c|}
\hline \multirow{3}{*}{ Island } & \multicolumn{4}{|c|}{ Total ecosystem carbon storage ( $\mathrm{TgC}$ ) } & \multirow{2}{*}{\multicolumn{2}{|c|}{$\begin{array}{l}\text { Change in mean total } \\
\text { ecosystem carbon storage }\end{array}$}} \\
\hline & \multirow{2}{*}{2011} & \multicolumn{3}{|c|}{2061} & & \\
\hline & & Mean & Upper & Lower & $(\mathrm{TgC})$ & (Percent) \\
\hline Hawai'i & 153.7 & 165.5 & 166.7 & 164.1 & 11.8 & 7.7 \\
\hline Kaho'olawe & 0.8 & 0.8 & 0.9 & 0.8 & 0.0 & 2.9 \\
\hline Kaua'i & 28.1 & 28.6 & 29.1 & 28.1 & 0.6 & 2.0 \\
\hline Lāna'i & 3.0 & 3.1 & 3.1 & 3.0 & 0.1 & 4.2 \\
\hline Maui & 31.3 & 32.9 & 33.2 & 32.5 & 1.6 & 5.0 \\
\hline Moloka'i & 8.8 & 9.3 & 9.5 & 9.2 & 0.5 & 5.6 \\
\hline O‘ahu & 27.2 & 27.3 & 27.8 & 26.8 & 0.2 & 0.6 \\
\hline Total & 252.9 & 267.6 & 269.2 & 265.9 & 14.7 & 5.8 \\
\hline
\end{tabular}



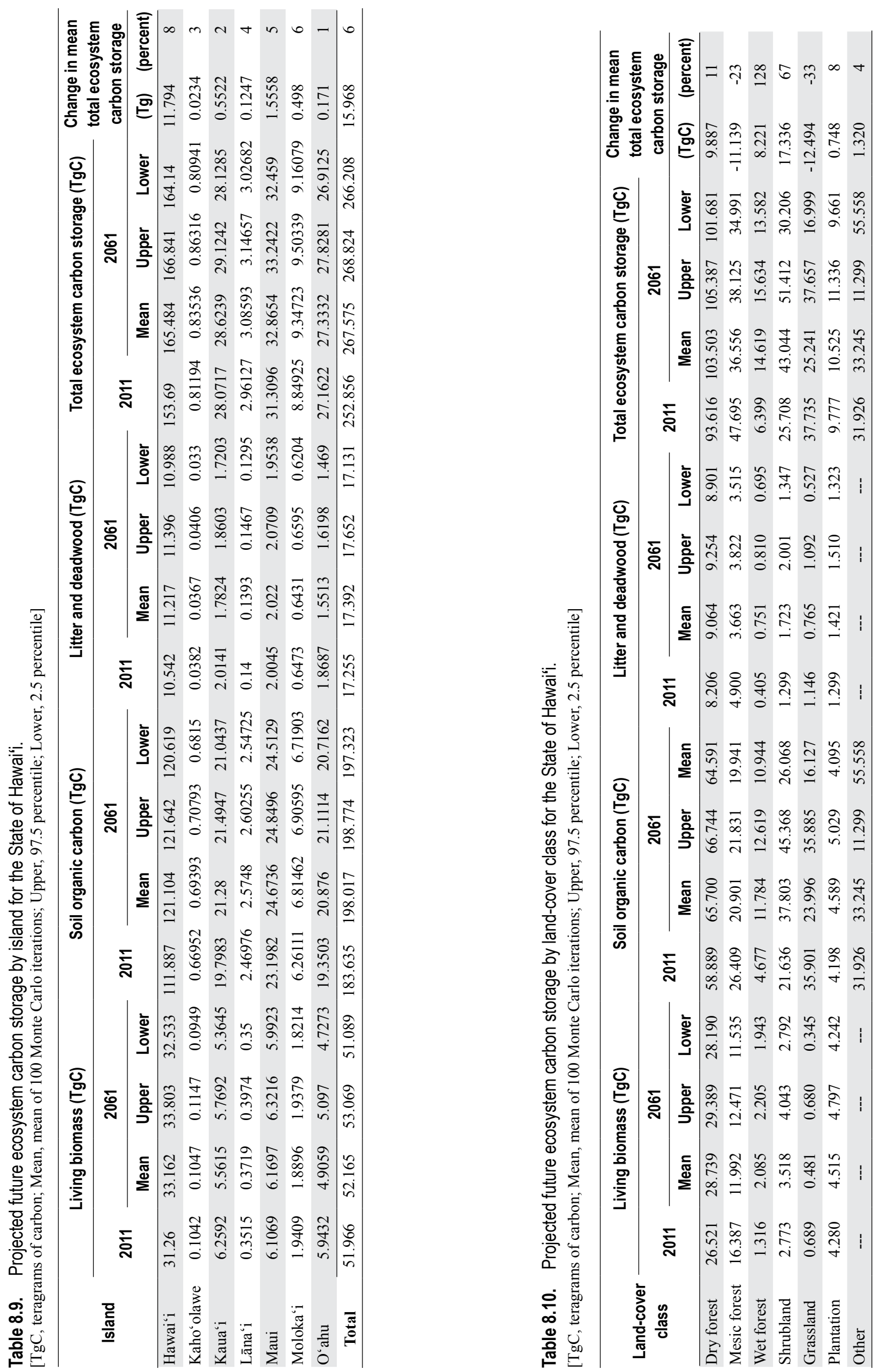
emissions from grassland fire accounted for an average of $0.006 \mathrm{TgC} / \mathrm{yr}$. Fire emissions across moisture zones were more evenly distributed than by state-class type; the mesic moisture zone accounted for $0.011 \mathrm{TgC} / \mathrm{yr}$, the dry moisture zone accounted for $0.009 \mathrm{TgC} / \mathrm{yr}$, and the wet moisture zone accounted for $0.008 \mathrm{TgC} / \mathrm{yr}$. Projected emissions for all combinations of state-class type and moisture zone are shown in figure 8.9.

\subsubsection{Effects of Major Controlling Processes}

The major controlling processes on ecosystem carbon dynamics considered in this assessment include land use and land-use change (for example, urbanization and agricultural expansion and contraction), wildfire, vegetation change (for example, shrub encroachment into grasslands), and the effects of climate change on the composition of moisture zones. In order to understand the relative forcing of each process we conducted a series of sensitivity tests in which each model parameter was omitted from the simulations. We compared estimates of ecosystem carbon stock at the year 2061 for each of the eight resulting alternative scenarios.

Moisture-zone change, shrub encroachment, and agricultural contraction increased ecosystem carbon storage, whereas wildfire, urbanization, and agricultural expansion reduced ecosystem carbon storage (fig. 8.10). Of the model parameters, changes involving land-use transitions had the largest impact on total ecosystem carbon storage. When urbanization was excluded from the model, estimates of ecosystem carbon stock were 4.0-7.4 $\mathrm{TgC}$ higher than the BAU scenario. Similarly, when agricultural expansion was excluded, ecosystem carbon stock was estimated to be between 1.5 and $3.5 \mathrm{TgC}$ higher than in the BAU scenario. Compared to land-use changes, wildfire had a small overall impact.

Assumptions about the rate of agricultural contraction had the largest impact on ecosystem carbon estimates. When excluded from the model, ecosystem carbon was projected to be 7.4-10.4 $\mathrm{TgC}$ lower than the BAU scenario-roughly equal to the impact of urbanization, agricultural expansion, and wildfire combined. Additionally, the net result of both moisture-zone change and shrub encroachment was an increase in ecosystem carbon storage, with mean departures from the BAU scenario of 1.3 and $0.9 \mathrm{TgC}$, respectively.

\subsection{Key Uncertainties and Limitations}

In conducting an assessment such as this, it is important to acknowledge key uncertainties that could have large effects on projection results. Typically, the largest sources of uncertainty when making future projections are associated with projecting changes in complex socioeconomic systems. To overcome this, many studies have used narrative storylines to guide quantification of a wide range of future conditions. Examples of this approach include the IPCC's Special Report on Emission Scenarios (Nakicenovic and Swart, 2000) and the Millennial Assessment
(Raskin and others, 2005). However, using these global scenario frameworks can prove challenging at local and regional scales as scenario assumptions may be interpreted in a variety of ways. Various methods of scenario downscaling have been explored, particularly for IPCC SRES scenarios, however no such downscaling was readily available for the State of Hawai' $i$. To overcome this limitation, we developed a BAU scenario based on empirically derived measurements of LULC change resulting from urbanization, agricultural expansion and contraction, and wildfire. Historical rates of change were incorporated into the LUCAS model, whereas in each timestep and Monte Carlo simulation the model would sample from the empirical data. For transition types where there was large historical variability (for example, wildfire), the model would project a wide range of future outcomes across the 100 Monte Carlo simulations. However, for some transition types, the historical data revealed temporally consistent trends, which were then carried forward in the scenario projections. This was especially true for trends in agriculture where historical data revealed a consistent net decrease over time. As shown in the sensitivity analysis, assumptions made regarding the rate and trajectory of change in the agricultural sector can have profound impacts on ecosystem carbon storage. As such, future work should consider development of additional scenarios to explore alternative narratives in agricultural expansion and contraction for the State of Hawai'i.

Forest age is an important model parameter used to control carbon-flux rates within the SF model. However, little is known about the distribution of forest age for the State of Hawai $i$. To overcome this data limitation, we assumed forest age was distributed uniformly across the landscape between 0 and 300 years old, likely an incorrect assumption. Additional work should focus on refining our estimate of forest-age structure, either through plot-based inventories or through known species-biomass relationships. This level of detail was out of the scope of this assessment but should be explored to improve the carbon SF modeling approach.

Future changes in climate can impact ecosystem carbon dynamics in several ways, including increasing and (or) decreasing growth rates owing to changes in temperature, precipitation, and $\mathrm{CO}_{2}$ fertilization. Because of the geography of the State of Hawai ${ }^{2} \mathrm{i}$ (isolated, small relative area, highly variable topography) there is a general lack of downscaled climate data available for incorporation into studies carried out at the scales and resolution of this assessment. For this research we incorporated projections of changes in moisture zones resulting from climate projections associated with the IPCC SRES A1B scenario. Future efforts should consider expanding the moisture-zone modeling to include new climate scenarios (Representative Concentration Pathways) and climate models (Coupled Model Intercomparison Project, CMIP5) to reflect a range of plausible futures. Additionally, with improved climate-model downscaling for the State of Hawai' $i$, alternative projections of temperature, precipitation, and $\mathrm{CO}_{2}$ concentration could be incorporated into the LUCAS model to reflect changes in NPP which is used to drive the carbon SF model. 

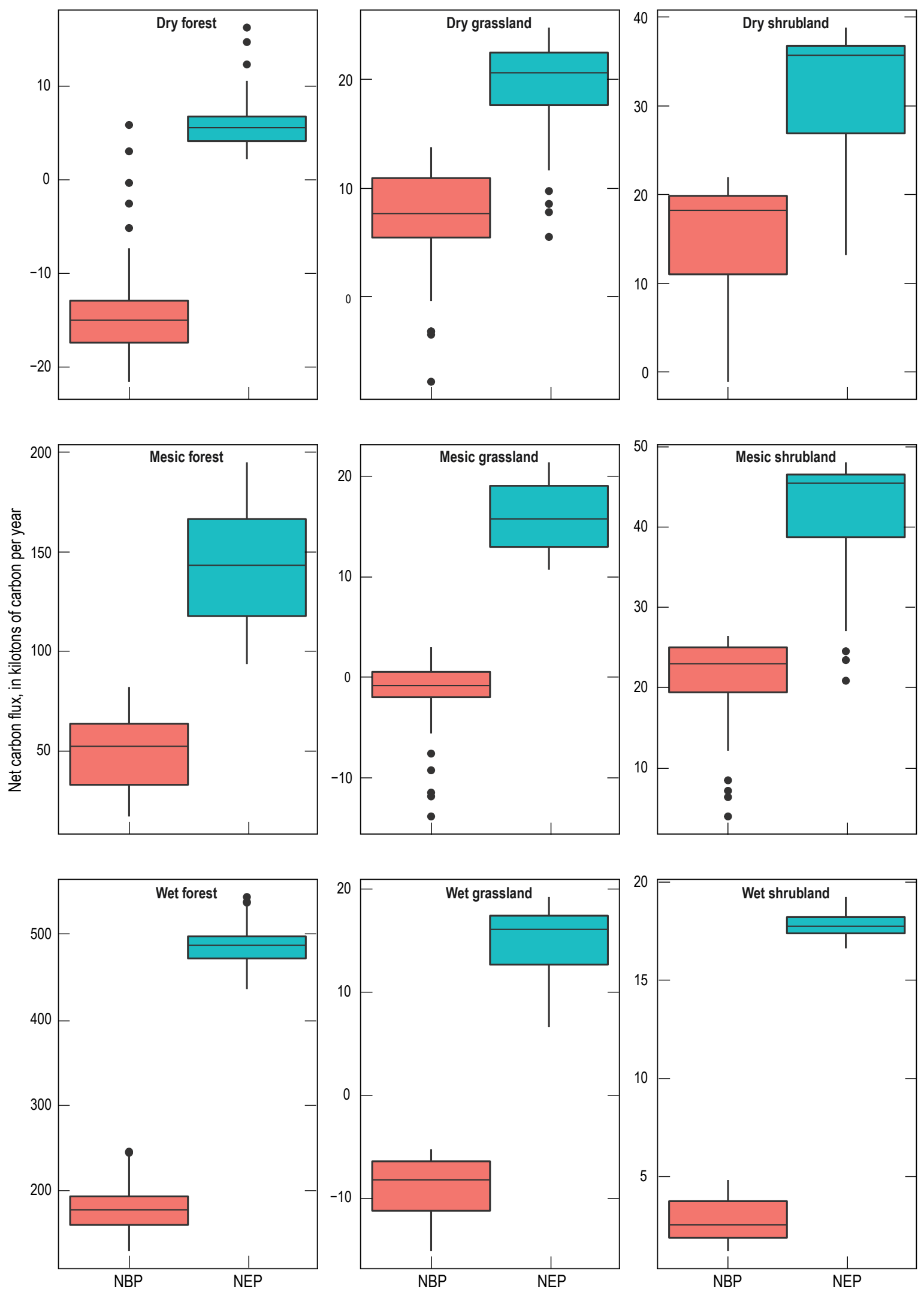

Figure 8.8. Distribution plots of net biome production (NBP) and net ecosystem production (NEP) during the projected future period (2011-2061) for the three major state-class types (forest, shrubland, grassland) and three moisture zones (dry, mesic, wet) considered in this assessment. Boxes represent the 25th and 75th percentile of years and whiskers represent the 10th and 90th percentile of years during the projected future period (2011-2061). 
Figure 8.9. Plots of projections of fire emissions across state-class type and moisture zone. The range of values represents the 95-percent confidence interval estimates across 100 Monte Carlo simulations. Dotted black lines show the mean estimates.
Figure 8.10. Plot of sensitivity analysis of major modeling assumptions. Values are cumulative differences in total ecosystem carbon stock compared to the "business as usual" (BAU) scenario by the year 2061.
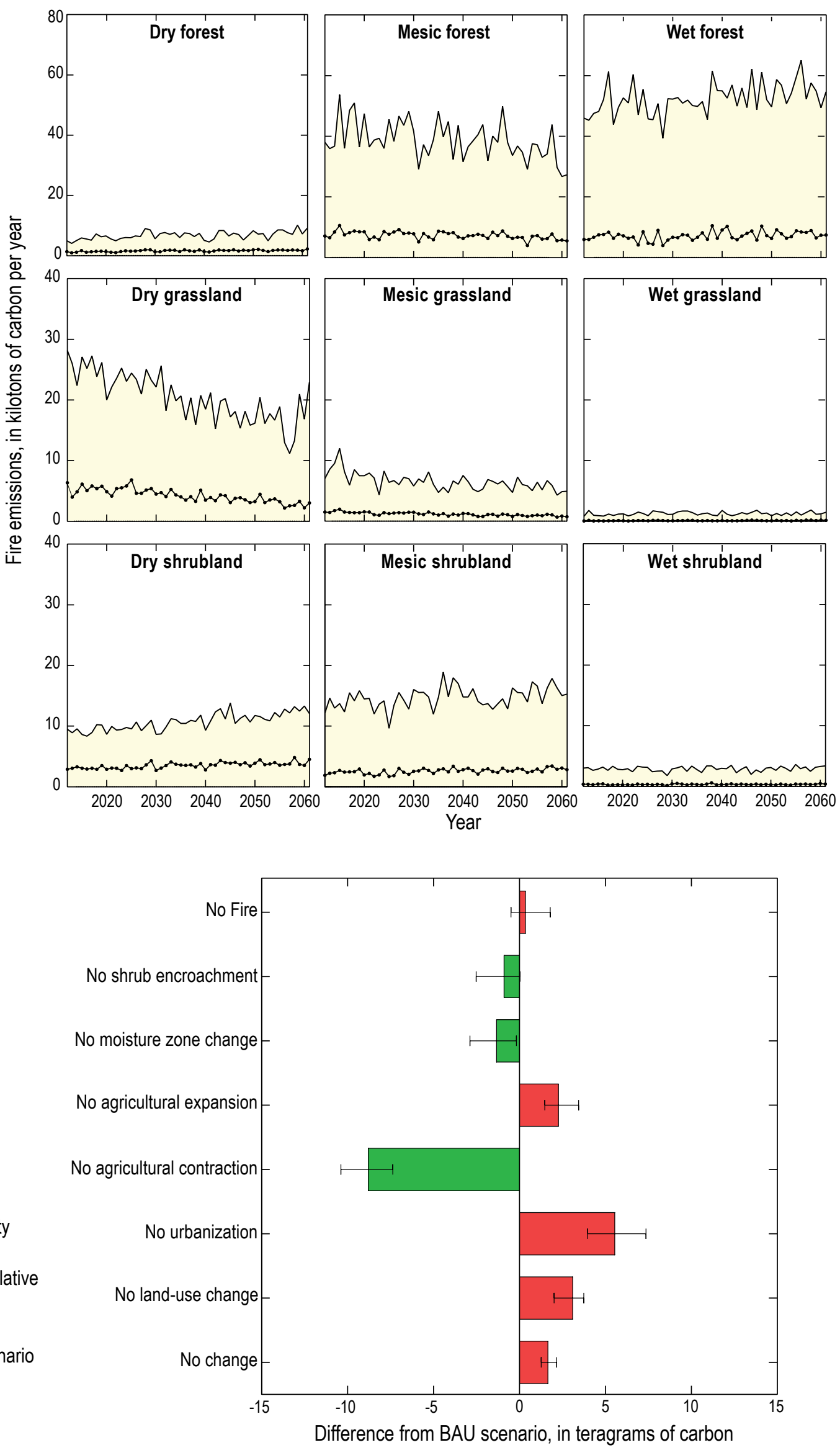
Projections of wildfire were based on a sampling protocol using a 10-year time series (2002-2011) from the Monitoring Trends in Burn Severity (MTBS) database. Because of the wide range of variability in the MTBS data, future projections of wildfire represented a wide range of future conditions. However, no long-term trend in wildfire was simulated owing to a lack of either empirically derived relationships of climate and fire or exogenous fire modeling as conducted in the assessment for the conterminous United States. Should additional downscaled climate data become available, alternative wildfire scenarios could be implemented as a means of exploring variability in this important source of terrestrial carbon emissions.

Land-management activities designed to increase terrestrial carbon storage were not explored for this assessment, but can readily be implemented using this modeling framework. Examples may include reforestation, development and utilization of carbon plantations, and biofuel production, among others. Work should be undertaken with local and state-level managers and policy makers to develop alternative land-management scenarios to explore the efficacy of increasing carbon storage and (or) sequestration rates.

\subsection{References Cited}

Ball, T.J., Woodrow, I.E., Berry, J.A., 1987, A model predicting stomatal conductance and its contribution to the control of photosynthesis under different environmental conditions, chap. 48 in Biggins, J., ed., Progress in Photosynthesis Research: Netherlands, Springer, p. 221-224, available at http:// dx.doi.org/10.1007/978-94-017-0519-6_48.

Botta, A., Viovy, N., Ciais, P., Friedlingstein, P., Monfray, P., 2000, A global prognostic scheme of leaf onset using satellite data: Global Change Biology, v. 6, no. 7, p. 709-725.

Daniel, C.J., Frid, L., 2012, Predicting landscape vegetation dynamics using state-and-transition simulation models, in Proceedings of the first Landscape State-and-Transition Simulation Modeling Conference, Portland, Oreg., June 14-16, 2011: Portland, Oreg., U.S. Department of Agriculture, Forest Service, Pacific Northwest Research Station General Technical Report PNW-GTR-869, 22 p. [Also available at https://www. fs.fed.us/pnw/pubs/pnw_gtr869/pnw_gtr869_002.pdf.]

Daniel, C.J., Frid, L., Sleeter, B.M., Fortin, M.-J., 2016, State-and-transition simulation models-A framework for forecasting landscape dynamics: Methods in Ecology and Evolution, v. 7, no. 11, p. 1413-1423, available at http://dx.doi. org/10.1111/2041-210X.12597.

Eidenshink, J., Schwind, B., Brewer, K., Zhu, Z.-L., Quayle, B., and Howard, S., 2007, A project for monitoring trends in burn severity: Fire Ecology, v. 3, no. 1, p. 3-21.
Farquhar, G.D., von Caemmerer, S., Berry, J.A., 1980, A biogeochemical model of photosynthetic $\mathrm{CO}_{2}$ assimilation in leaves of C3 species: Planta, v. 149, no. 1, p. 78-90.

Foley, J.A., Prentics, C., Ramankutty, N., Levis, S., Pollard, D., Sitch, S., Haxeltine, A., 1996, An integrated biosphere model of land surface processes, terrestrial carbon balance, and vegetation dynamics: Global Biogeochemical Cycles, v. 10, no. 4, p. 603-628.

Houghton, R.A., Hacker, J.L., and Lawrence, K.T., 1999, The U.S. carbon budget - contributions from land-use change: Science, v. 285, p. $574-578$.

Intergovernmental Panel on Climate Change (Paustian, K., Ravindranath, N.H., Amstel, A.), 2006, Volume 4-Agriculture, forestry and other land use, in Eggleston, H.S., Buendia, L., Miwa, K., Ngara, T., and Tanabe, K., eds., 2006 IPCC guidelines for national greenhouse gas inventories: Hayama Japan, Institute for Global Environmental Strategies, prepared by the National Greenhouse Gas Inventories Programme, available at http://www.ipcc-nggip.iges.or.jp/public/2006gl/ vol4.html.

Kucharik, C.J., Foley, J.A., Delire, C., Fisher, V.A., Coe, M.T., Lenters, J.D., Young-Molling, C., Ramankutty, N., Norman, J.M., Gower, S.T., 2000, Testing the performance of a dynamic global ecosystem model - water balance, carbon balance, and vegetation structure: Global Biogeochemical Cycles, v. 14, no. 3, p. 795-825.

Liu, Z., Wimberly, M., Lamsal, A., Sohl, T., Hawbaker, T., 2015, Climate change and wildfire risk in an expanding wildlandurban interface - a case study from the Colorado Front Range Corridor: Landscape Ecology, v. 30, no. 10, p. 1943-1957, available at http://dx.doi.org/10.1007/s10980-015-0222-4.

Nakicenovic, N., Swart, R., eds., 2000, IPCC Special Report on Emission Scenarios: Cambridge, England, Cambridge University Press, 570 p, available at http://www.ipcc.ch/ ipccreports/sres/emission/index.php?idp $=0$.

National Oceanic and Atmospheric Administration, 2013, Coastal Change Analysis Program (C-CAP) Regional Land Cover Data - Coastal United States: Charleston, S.C., NOAA's Ocean Service, Office for Coastal Management, available at https://coast.noaa.gov/digitalcoast/data/ ccapregional/.

Soil Survey Staff, 2015, Gridded Soil Survey Geographic (gSSURGO) Database for Hawaii: United States Department of Agriculture, Natural Resources Conservation Service, accessed August 21, 2015 at https://gdg.sc.egov. usda.gov/ (FY2016 official release).

Osher, L.J., Matson, P.A., Amundson, R., 2003, Effect of land use change on soil carbon in Hawaii: Biogeochemistry, v. 65 , no. 2 , p. $213-232$. 
Parton, W.J., Schimel, D.S., Cole, C.V., Ojima, D.S., 1987, Analysis of factors controlling soil organic matter levels, in Great Plains grasslands: Soil Science Society of Americal Journal, v. 51, no. 5, p. 1173-1179.

Parton, W.J., Scurlock, J.M.O., Ojima, D.S., Gilmanov, T.G., Scholes, R.J., Schimel, D.S., Kirchner, T., Menaut, J.C., Seastedt, T., Garcia Moya, E., Kamnalrut, A., Kinyamario, J.I., 1993, Observations and modeling of biomass and soil organic matter dynamics for the grassland biome worldwide: Global Biogeochemical Cycles, v. 7, no. 4, p. $785-809$.

Raskin, P., Monks, F., Ribeiro, T., van Vuuren, D., Zurek, M., 2005, Global scenarios in historical perspective, chap. 2 of Carpenter, S., Pingali, P., Bennett, E., Zurek, M., eds., Ecosystems and Human Well-Being - Scenarios: Washington, D.C., Island Press, Findings of the Scenarios Working Group, Millennium Ecosystem Assessment Series, p. 35-44.
Sleeter, B.M., Liu, J., Daniel, C., Frid, L., Zhu, Z., 2015, An integrated approach to modeling changes in land use, land cover, and disturbance and their impact on ecosystem carbon dynamics - a case study in the Sierra Nevada Mountains of California: AIMS Environmental Science, v. 2 , no. 3, p. 577-606, available at http://dx.doi. org/10.3934/environsci.2015.3.577.

Verberne, E., Hassink, J., De Willigen, P., Groot, J., Van Veen, J., 1990, Modeling organic matter dynamics in different soils: Netherlands Journal of Agricultural Science, v. 38, no. 3, p. 221-238. 


\title{
Chapter 9. Hawai'i Carbon Balance
}

\author{
By Paul C. Selmants, ${ }^{1}$ Christian P. Giardina, ${ }^{2}$ Benjamin M.Sleeter, ${ }^{1}$ Jinxun Liu, ${ }^{1}$ and Zhiliang Zhu ${ }^{1}$
}

\subsection{Highlights}

- Ecosystem carbon balance of the seven main Hawaiian Islands (as outlined in Giardina and others, this volume, chap. 1) was estimated for two periods, a current baseline period (2004-2013) and a projected period (2012-2061), by synthesizing results for baseline carbon emissions from wildfire (Hawbaker and others, this volume, chap. 5), baseline carbon stocks and fluxes (Selmants and others, this volume, chap. 6), baseline and projected future aquatic carbon fluxes to nearshore waters (MacKenzie and others, this volume, chap. 7), and projected future carbon stocks and fluxes (Sleeter and others, this volume, chap. 8).

- Terrestrial ecosystems of the seven main Hawaiian Islands sequestered an average of $0.34 \mathrm{TgC} / \mathrm{yr}$ during the baseline period, which was about 4 percent of statewide terrestrial net primary production (NPP). Hawai' $i$ Island represented the largest carbon sink, sequestering $0.24 \mathrm{TgC} / \mathrm{yr}$ or 70 percent of total statewide carbon sequestration.

- The combined carbon-leaching losses to nearshore waters through stream-water flux and submarine groundwater discharge was estimated as about $0.31 \mathrm{TgC} / \mathrm{yr}$, or about 4 percent of statewide terrestrial NPP.

- During the projected period (2012-2061), carbon sequestration of terrestrial ecosystems of the State of Hawai ${ }^{i} i$ was predicted to decrease by more than 30 percent ( 0.34 to $0.22 \mathrm{TgC} / \mathrm{yr}$ ) primarily because of a decrease in NPP and increased carbon losses from land-use and land-cover change, as well as increased aquatic carbon-leaching losses to nearshore waters.

- Our analysis indicates that the State of Hawai'i would remain a net carbon sink overall, primarily because of carbon sequestration in terrestrial ecosystems on Hawai' $i$ Island, but that predicted land-use changes on the islands of Kaua' $\mathrm{i}$ and $\mathrm{O}^{\text {' }} \mathrm{ahu}$ would convert these islands from net carbon sinks to net carbon sources to the atmosphere.

${ }^{1}$ U.S. Geological Survey.

${ }^{2}$ U.S. Department of Agriculture Forest Service.

\subsection{Introduction}

Hawai' $i$ is unique among the United States because of its isolation, tropical climate, discontinuous landmass, high degree of endemism, history of land-cover conversion, and dominance of some areas by invasive species. The year-round growing season, high rainfall on windward sides of islands and high fertility of volcanically derived soils all indicate that terrestrial ecosystems of Hawai' $i$ have a high capacity to influence the exchange of carbon dioxide $\left(\mathrm{CO}_{2}\right)$ between ecosystems and the atmosphere and influence the overall ecosystem carbon balance of the state. However, much of Hawai' $i$ has not previously been included in any major national carbon and greenhouse inventory reports. Thus, the current baseline carbon balance is poorly understood at a statewide level, and the potential for climate and land-use change to affect carbon dynamics in Hawai' $i$ has not been formally assessed.

The main outcomes of the U.S. Geological Survey carbon assessment for Hawai' $i$ include (1) estimates of the amount of carbon stored in ecosystems, (2) estimates of the capacity of ecosystems to sequester carbon, (3) estimates of the rate of carbon fluxes in and out of the ecosystems, and (4) evaluation of the effects of processes or driving forces that control ecosystem carbon balance. To support the outcomes of the assessment for the entire State of Hawai ${ }^{i} i$ the assessors sought to address the magnitude of carbon pools and fluxes in terrestrial ecosystems of the Hawaiian Islands and how the carbon balance of these ecosystems might be influenced by climate change, wildfire, leaching losses of carbon to nearshore waters and changes in land use and land cover. Chapters 2 through 8 of this assessment addressed these goals separately for different components and questions. In this chapter we focus on synthesizing results across terrestrial ecosystems of the Hawaiian Islands to summarize information at the statewide level on changes in carbon stocks, carbon fluxes, and ecosystem carbon balance for current baseline (2004-2013) and projected future (2012-2061) periods.

\subsection{Input Data and Methods}

For the current baseline period, we synthesized estimates of net primary production (NPP) and heterotrophic respiration $\left(R_{\mathrm{h}}\right)$ from Selmants and others (this volume, chap. 6), aquatic fluxes to 
nearshore waters from MacKenzie and others (this volume, chap. 7), and fire emissions from Hawbaker and others (this volume, chap. 5) and compare these to the first 5 years (2012-2016) of modeled simulation estimates of carbon fluxes by the IBIS ecosystem carbon submodel from Sleeter and others (this volume, chap. 8). Estimates of NPP derived from statewide MODIS GPP (MOD17) were used to calibrate the IBIS annual NPP estimates, and baseline fire estimates from Hawbaker and others (this volume, chap. 5) were used to parameterize IBIS annual carbon emissions from wildfire. Estimates of baseline carbon fluxes to nearshore waters from stream- and groundwater discharge from MacKenzie and others (this volume, chap. 7) were not used to either parameterize or calibrate IBIS-submodel estimates of carbon-leaching losses, so these independent estimates can be used to cross-validate each other. Likewise, estimates of $R_{\mathrm{h}}$ were derived from regression-based estimates of ecosystem respiration $\left(R_{\mathrm{e}}\right)$ (Selmants and others, this volume, chap. 6) minus MODISbased estimates of NPP and were not incorporated into IBIS estimates of $R_{\mathrm{h}}$; these estimates can be cross validated with one another, as can estimates of net ecosystem production (NEP), the difference between NPP and $R_{\mathrm{h}}$. For the current baseline period, mean annual carbon fluxes were calculated separately by island and expressed in $\mathrm{TgC} / \mathrm{yr}$.

For the projected future period (2012-2016), net ecosystem carbon balance (NECB) (see Chapin and others, 2006) for terrestrial ecosystems was calculated as follows:

$\mathrm{NECB}=\mathrm{NPP}-R_{\mathrm{h}}-$ Fire $\mathrm{C}-\mathrm{C}$ leaching loss - Land Use $\mathrm{C}$ flux

for which the abbreviations for the fluxes are defined as above. Land Use $\mathrm{C}$ flux is a brief pulse of carbon lost to the atmosphere associated with land clearing and conversion, for example, urbanization and conversion to agriculture. We also compare independent estimates of projected future carbon losses from terrestrial ecosystems through stream- and groundwater discharge to nearshore marine waters from MacKenzie and others (this volume, chap. 7) and Sleeter and others (this volume, chap. 8), both of which are based on projected future changes in moisture zones induced by climate change as described in Fortini and others (this volume, chap. 3).

\subsection{Results and Discussion}

\subsubsection{Synthesis of Carbon Dynamics in the Baseline Period (2004-2013)}

Baseline estimates of terrestrial ecosystem carbon stocks and fluxes from Hawbaker and others (this volume, chap. 5), Selmants and others (this volume, chap. 6), and MacKenzie and others (this volume, chap. 7) are summarized in figure 9.1. We estimate that NEP of the State of Hawai' $i$ currently ranges from 0.9 to $2.4 \mathrm{TgC} / \mathrm{yr}$ (table 9.1) because estimates of NPP exceed estimates of $R_{\mathrm{h}}$ for all seven of the main Hawaiian Islands during this period. Although estimates of NPP derived from MODIS GPP described in Selmants and others (this volume, chap. 6) were used to calibrate NPP estimates from the IBIS submodel described in Sleeter and others (this volume, chap. 8), the statewide IBIS estimates of mean annual NPP for the first 5 years of the simulation were about 13 percent lower than the statewide estimates of mean annual NPP derived from MODIS data (table 9.1). This can be explained in part by land-use and land-cover changes during this initial simulation period. The independent estimates of $R_{\mathrm{h}}$ are much more similar, differing by only about 2 percent statewide (table 9.1.). However, $R_{\mathrm{h}}$ represented about 90 percent of NPP in the IBIS-submodel simulation, whereas the regression-based estimate of statewide $R_{\mathrm{h}}$ derived from the relationship between $R_{\mathrm{e}}$ and GPP from Selmants and others (this volume, chap. 6) represents only about 77 percent of NPP estimated from MODIS GPP data (table 9.1). The combination of lower NPP and higher $R_{\mathrm{h}}$ estimates in the IBIS submodel result in a statewide estimate of NEP that is less than half that of NEP estimated by the combined MODISregression approach (table 9.1). Mean annual carbon emission from wildfire for the years 2002-2011 was estimated to be $0.027 \mathrm{TgC} / \mathrm{yr}$ with a range of $0.002-0.06 \mathrm{TgC} / \mathrm{yr}$ (Hawbaker and others, this volume, chap. 5). Estimates from the first 5 years of the simulation were similar - statewide mean annual carbon emissions from wildfire were estimated to be 0.029 $\mathrm{TgC} / \mathrm{yr}$ from 2012 to 2016, with a range of $0.002-0.12 \mathrm{TgC} / \mathrm{yr}$, which is unsurprising given that wildfire area burned and carbon emissions from Hawbaker and others (this volume, chap. 5) were used to parameterize the Land Use and Carbon Scenario Simulator (LUCAS) model described in Sleeter and others (this volume, chap. 8).

The baseline estimates of aquatic carbon fluxes to nearshore waters from MacKenzie and others (this volume, chap. 7) are the sum of estimates of organic and inorganic carbon fluxes in stream water and submarine groundwater discharge, and were calculated independently from estimates of carbon-leaching losses estimated for the first 5 years of the simulation by the LUCAS model (Sleeter and others, this volume, chap. 8); in other words, estimates from MacKenzie and others (this volume, chap. 7) were not used to either parameterize or calibrate the IBIS-submodel estimates of leaching losses described in Sleeter and others (this volume, chap. 8). Nevertheless, these independent estimates of carbon lost from terrestrial ecosystems by leaching into streams and groundwater are strikingly similar, differing by less than 1 percent statewide (table 9.2).

\subsubsection{Assessment of Projected Future Carbon Dynamics (2012-2061)}

Our assessment of statewide projected future estimated carbon dynamics of Hawai'i (2012-2061) are based almost entirely on the LUCAS model results from Sleeter and others (this volume, chap. 8). The only exception is a comparison of projected future aquatic carbon losses to nearshore waters 


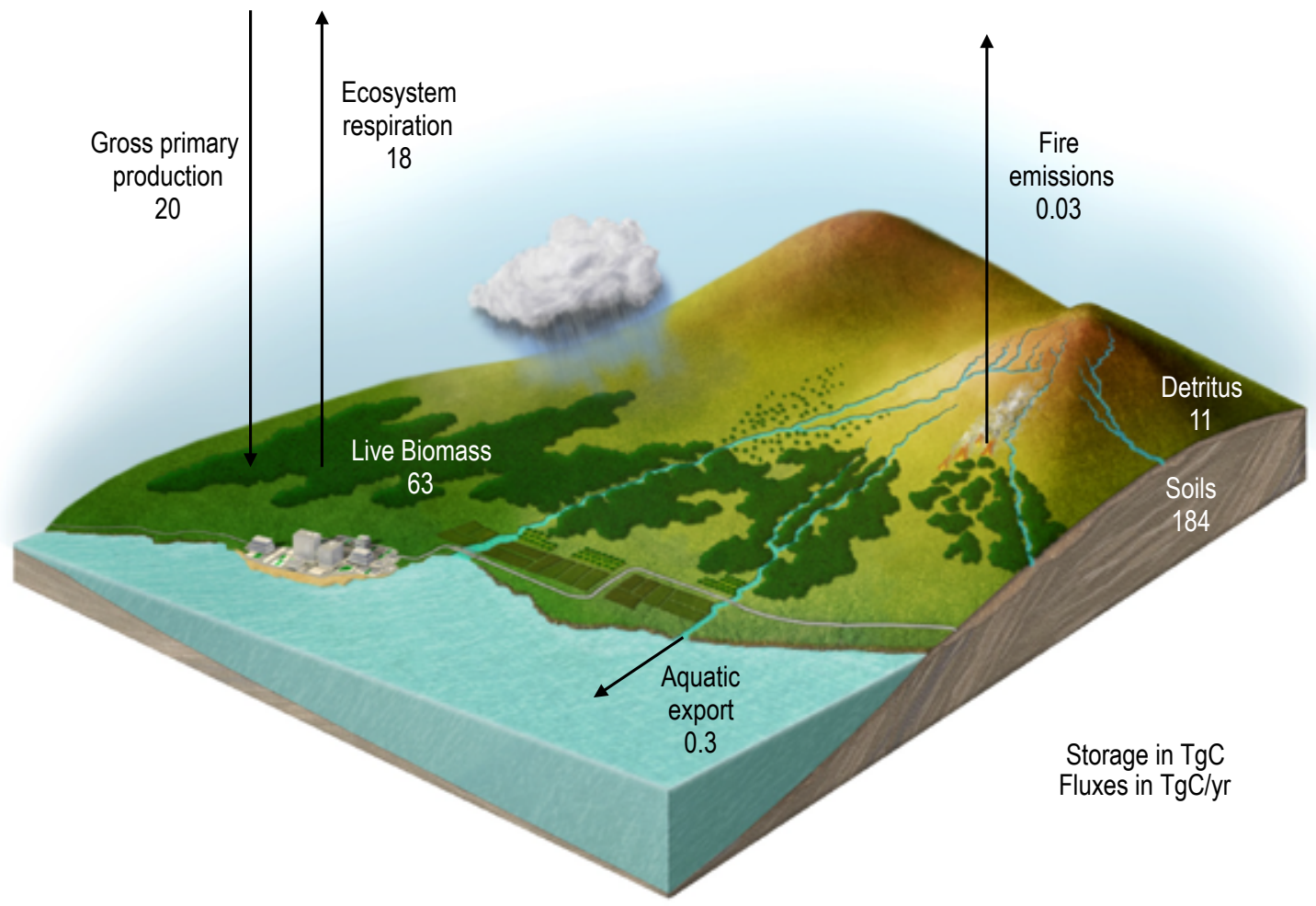

Figure 9.1. Diagram showing summary of current baseline carbon stocks and fluxes for the State of Hawai'i. TgC, teragrams of carbon; TgC/yr, teragrams of carbon per year.

Table 9.1. Comparison of baseline estimates of net primary production, heterotrophic respiration, and net ecosystem production for the seven main Hawaiian Islands.

[MODIS GPP data and regression estimates of ecosystem respiration $\left[R_{\mathrm{e}}\right]$ from Selmants and others (this volume, chap. 6) and IBIS model data from Sleeter and others (this volume, chapter 8). NPP, net primary production; $R_{\mathrm{h}}$ heterotrophic respiration; NEP, net ecosystem production ( $\mathrm{NPP}-R_{\mathrm{h}}$ ); $\mathrm{TgC} / \mathrm{yr}$, teragrams of carbon per year]

\begin{tabular}{|c|c|c|c|c|c|c|}
\hline Island & $\begin{array}{l}\text { NPP (TgC/yr) } \\
\text { MODIS }\end{array}$ & $\begin{array}{l}\text { NPP (TgC/yr) } \\
\text { IBIS }\end{array}$ & $\begin{array}{c}R_{\mathrm{h}}(\mathrm{TgC} / \mathrm{yr}) \\
\text { MODIS regression }\end{array}$ & $\begin{array}{c}R_{\mathrm{h}}(\mathrm{TgC} / \mathrm{yr}) \\
\text { IBIS }\end{array}$ & $\begin{array}{c}\text { NEP (TgC/yr) } \\
\text { MODIS-regression }\end{array}$ & $\begin{array}{c}\text { NEP (TgC/yr) } \\
\text { IBIS }\end{array}$ \\
\hline Hawai‘i & 5.58 & 5.51 & 4.41 & 4.93 & 1.17 & 0.586 \\
\hline Kaho'olawe & 0.03 & 0.02 & 0.02 & 0.02 & 0.01 & 0.001 \\
\hline Lāna‘i & 0.19 & 0.09 & 0.14 & 0.08 & 0.05 & 0.005 \\
\hline Maui & 1.29 & 1.01 & 1.00 & 0.91 & 0.29 & 0.108 \\
\hline Total & 10.17 & 8.87 & 7.78 & 7.96 & 2.39 & 0.903 \\
\hline
\end{tabular}

Table 9.2. Comparison of baseline and projected future nearshore aquatic carbon fluxes to leaching losses of carbon.

[Baseline and projected future aquatic carbon fluxes to nearshore waters from MacKenzie and others (this volume, chap. 7) and leaching losses of carbon from Sleeter and others (this volume, chap. 8). Aquatic fluxes of nearshore waters are projected out to 2100, whereas leaching losses are projected out to 2061.

$\mathrm{TgC} / \mathrm{yr}$, teragrams of carbon per year]

\begin{tabular}{|c|c|c|c|c|}
\hline Island & $\begin{array}{l}\text { Baseline aquatic flux } \\
\text { (TgC/yr) }\end{array}$ & $\begin{array}{l}\text { IBIS Baseline leaching loss } \\
\text { (TgC/yr) }\end{array}$ & $\begin{array}{l}\text { Projected future aquatic flux } \\
\text { (TgC/yr) }\end{array}$ & $\begin{array}{l}\text { IBIS projected future leaching loss } \\
\text { (TgC/yr) }\end{array}$ \\
\hline Hawai'i & 0.166 & 0.206 & 0.207 & 0.236 \\
\hline Kaho'olawe & $<0.001$ & $<0.001$ & $<0.001$ & $<0.001$ \\
\hline Lāna'i & 0.002 & $<0.001$ & 0.002 & $<0.001$ \\
\hline Maui & 0.045 & 0.038 & 0.058 & 0.043 \\
\hline Total & 0.311 & 0.314 & 0.369 & 0.345 \\
\hline
\end{tabular}


from MacKenzie and others (this volume, chap. 7) to those of the LUCAS model (Sleeter and others, this volume, chap. 8), both of which are based on projected moisture-zone changes described in Fortini and others (this volume, chap. 3). Overall carbon storage in terrestrial ecosystems was projected to increase by an average of about $0.29 \mathrm{TgC} / \mathrm{yr}$ during the 50 -year course of the projected future period (fig. 9.2), almost entirely from increases in soil organic carbon storage (Sleeter and others, this volume, chap. 8). Carbon input from NPP is projected to average $8.69 \mathrm{TgC} / \mathrm{yr}$ from 2012 to 2061 (fig. 9.2), decreasing by an average of about 6 percent from the first 10 years of the simulation period $(8.87 \mathrm{TgC} / \mathrm{yr})$ to the final 10 years $(8.36 \mathrm{TgC} / \mathrm{yr})$. Projected estimates of $R_{\mathrm{h}}$ average $7.84 \mathrm{TgC} / \mathrm{yr}$ from 2012 to 2061 (fig. 9.2), with $R_{\mathrm{h}}$ projected to decrease by an average of about 4 percent from the first 10 years of the simulation period $(7.96 \mathrm{TgC} / \mathrm{yr})$ to the final 10 years $(7.64 \mathrm{TgC} / \mathrm{yr})$. The slightly more rapid statewide decrease in NPP compared to $R_{\mathrm{h}}$ results in about a 14 percent $(0.13 \mathrm{TgC} / \mathrm{yr})$ overall decrease in statewide NEP during the 50 -year simulation period, contributing to a reduction in statewide carbon sequestration potential for the Hawaiian Islands (table 9.3).

Aquatic carbon-leaching losses to stream water and groundwater, and eventually to nearshore marine waters, represent the largest, non-respiratory loss of carbon from terrestrial ecosystems of Hawai $i$. The LUCAS model projects about a 10 percent increase in carbon loss from terrestrial ecosystems by leaching to nearshore waters during the 50 -year simulation period, from an average of $0.314 \mathrm{TgC} / \mathrm{yr}$ during the first 5 years of the simulation period (2012-2016) to an average of $0.345 \mathrm{TgC} / \mathrm{yr}$ during the final 5 years of the simulation period (2051-2061; table 9.2). Independent projections (MacKenzie and others, this volume, chap. 7) of aquatic carbon flux to nearshore waters estimate an increase of about 19 percent from the current baseline period $(0.311 \mathrm{TgC} /$ yr) to the year $2100(0.369 \mathrm{TgC} / \mathrm{yr}$; table 9.2$)$-a similar rate of annual increase to the LUCAS model projections. Leaching losses of carbon from terrestrial ecosystems to nearshore marine waters are projected to average about $0.33 \mathrm{TgC} / \mathrm{yr}$ from 2012 to 2061 (fig. 9.2).

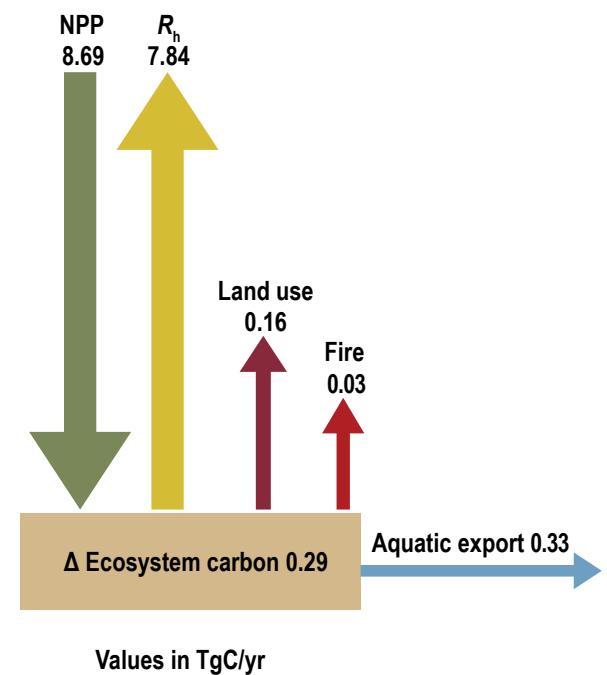

Figure 9.2. Diagram showing projected future mean annual carbon fluxes and change in ecosystem carbon storage for the State of Hawaii $i$ averaged across the 50-year future simulation period (2012-2061). $\mathrm{NPP}$, net primary production; $R_{\mathrm{h}}$, heterotrophic respiration; $\mathrm{TgClyr}$, teragrams of carbon per year.

The projected future decrease in NEP (table 9.3), combined with the projected increase in carbon losses from leaching and from emissions related to land-use and landcover change (Sleeter and others, this volume, chap. 8), led to a more than 30 percent projected decrease in NECB during the 50 -year simulation period (fig. 9.3), from a statewide average of $0.34 \mathrm{TgC} / \mathrm{yr}$ during the first 10 years of the simulation period (2012-2021) to an average of $0.22 \mathrm{TgC} / \mathrm{yr}$ during the final 10 years of the simulation period (2051-2061; table 9.4). This overall decrease in NECB represents a substantial weakening of statewide carbon-sink strength (fig. 9.3), and is projected to convert the islands of Kaua' $\mathrm{i}$ and $\mathrm{O}^{\prime}$ ahu from net sinks to net sources of $\mathrm{CO}_{2}$ to the atmosphere (9.4). The overall statewide decrease in NECB is due to reduced carbon sequestration potential related to land-use change- primarily urbanization (Sleeter and others, this volume, chap. 8).

Table 9.3. Projected changes in net ecosystem production during the 50-year future simulation period for the seven main Hawaiian Islands.

[Net ecosystem production (NEP) is net primary production minus heterotrophic respiration. $\mathrm{ktC} / \mathrm{yr}$, kilotons of carbon per year]

\begin{tabular}{|c|c|c|c|c|c|c|}
\hline \multirow[t]{2}{*}{ Island } & \multicolumn{3}{|c|}{$\begin{array}{l}\text { Net ecosystem production (ktC/yr): } \\
\text { 2011-2021 }\end{array}$} & \multicolumn{3}{|c|}{$\begin{array}{l}\text { Net ecosystem production (ktC/yr): } \\
2051-2061\end{array}$} \\
\hline & Mean & Upper $(97.5 \%)$ & Lower $(2.5 \%)$ & Mean & Upper $(97.5 \%)$ & Lower (2.5\%) \\
\hline Hawai‘i & 586 & 665 & 508 & 535 & 619 & 454 \\
\hline Kaho'olawe & 1 & 2 & 1 & 1 & 1 & 0 \\
\hline Kaua‘i & 100 & 117 & 83 & 73 & 88 & 58 \\
\hline Lāna‘i & 5 & 6 & 3 & 4 & 5 & 3 \\
\hline O`ahu & 78 & 94 & 61 & 52 & 64 & 39 \\
\hline Total & 903 & 1104 & 701 & 778 & 972 & 581 \\
\hline
\end{tabular}


Table 9.4. Projected changes in net ecosystem carbon balance during the 50-year future simulation period for the seven main Hawaiian Islands. [NECB, net ecosystem carbon balance (net ecosystem production minus carbon losses from fire, land use, and aquatic export to nearshore waters); ktC/yr, kilotons of carbon per year]

\begin{tabular}{|c|c|c|c|c|c|c|}
\hline \multirow{2}{*}{ Island } & \multicolumn{3}{|c|}{ NECB (ktC/yr): 2011-2021 } & \multicolumn{3}{|c|}{ NECB (ktC/yr): 2051-2061 } \\
\hline & Mean & Upper $(97.5 \%)$ & Lower $(2.5 \%)$ & Mean & Upper $(97.5 \%)$ & Lower $(2.5 \%)$ \\
\hline Hawai‘i & 236 & 323 & 153 & 208 & 290 & 129 \\
\hline Kaho'olawe & 1 & 2 & 0 & 0 & 1 & -1 \\
\hline Kaua'i & 33 & 56 & 12 & -11 & 18 & -40 \\
\hline Lāna'i & 3 & 5 & 1 & 2 & 4 & 0 \\
\hline Maui & 40 & 62 & 20 & 18 & 39 & -2 \\
\hline Total & 341 & 592 & 80 & 224 & 454 & -6 \\
\hline
\end{tabular}

\subsection{Conclusions}

Our synthesis of carbon dynamics in Hawai'i indicates that the terrestrial ecosystems of the state currently sequester about $0.34 \mathrm{TgC} / \mathrm{yr}$, which is almost 4 percent of statewide NPP. Terrestrial ecosystems of the seven main Hawaiian Islands offset about 7 percent of anthropogenic emissions, which were estimated at $4.9 \mathrm{TgC}$ for 2013 and were primarily from energy and transportation. Hawai' $i$ Island represented the largest carbon sink at $263 \mathrm{TgC} / \mathrm{yr}$ during the baseline period, which was about 70 percent of the statewide carbon sink. Near the end of the simulation period (2051-2061) the statewide carbon sink was projected to decrease to about 2.7 percent of NPP. Terrestrial ecosystems would be projected to offset only 5 percent of anthropogenic emissions if they remained at 2013 levels. Hawai' $i$ Island was projected to represent more than 90 percent of the statewide carbon sink near the end of the simulation period, with the islands of Kaua' $\mathrm{i}$ and $\mathrm{O}^{\text {'ahu }}$ projected to be converted from net sinks to net sources of $\mathrm{CO}_{2}$ to the atmosphere.

The results of the current synthesis have implications for carbon management strategies that might be aimed at offsetting anthropogenic emissions in the State of Hawai' $i$. However, several factors that could influence the carbon balance of terrestrial ecosystems of Hawai' $i$ were not considered in this assessment, these include increasing atmospheric $\mathrm{CO}_{2}$ concentrations influencing $\mathrm{CO}_{2}$ fertilization on NPP (carbon input) and increasing temperatures having direct and indirect effects on NPP and $R_{\mathrm{h}}$ (carbon loss) through plant physiological responses and changes in rates of decomposition and nutrient cycling. It is also important to recognize the uncertainties in the results reported here, primarily in the estimates of respiratory carbon losses. Incorporation of eddy flux data from Hawai' $i$ and an ensemble process-based simulation modeling approach

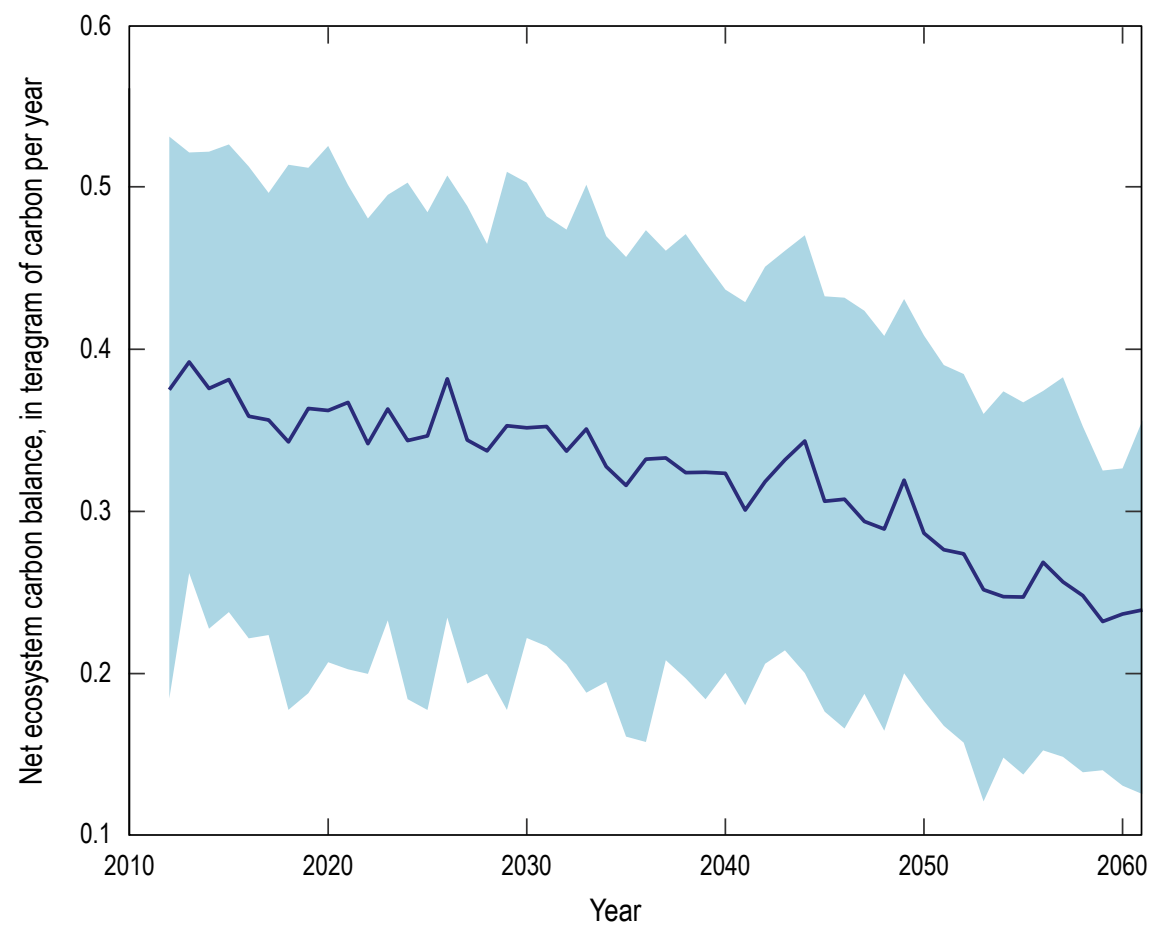

Figure 9.3. Plot showing projected future annual net ecosystem carbon balance (NECB) of the State of Hawaii for each year of the 50-year future simulation period (2012-2061). Each annual value for NECB is the mean of 100 Monte Carlo iterations from the Land Use and Carbon Scenario Simulator (LUCAS) model (see Sleeter and others, this volume, chap. 8). 
would increase confidence in future estimates of carbon balance and sequestration potential of Hawaiian ecosystems. Reduction in these uncertainties will require enhancements in observation systems; research on landscape dynamics; process-based modeling research; and more detailed, realistic land-management and policy scenarios. Key enhancements in observation systems include increased biomass measurements in shrublands and grasslands of Hawai' $i$, estimates of NPP and crop biomass in agricultural areas, and stream-water carbon export from ephemeral streams. Increasing the detail of land-management and policy scenarios related to agricultural expansion, wildfire suppression and prevention, and restoration of ecosystems dominated by invasive species would provide a wider range of variables as inputs to the LUCAS state and transition model. Despite these limitations, the analyses presented here provide valuable information for setting research and policy priorities that should reduce uncertainties and improve future assessments. 


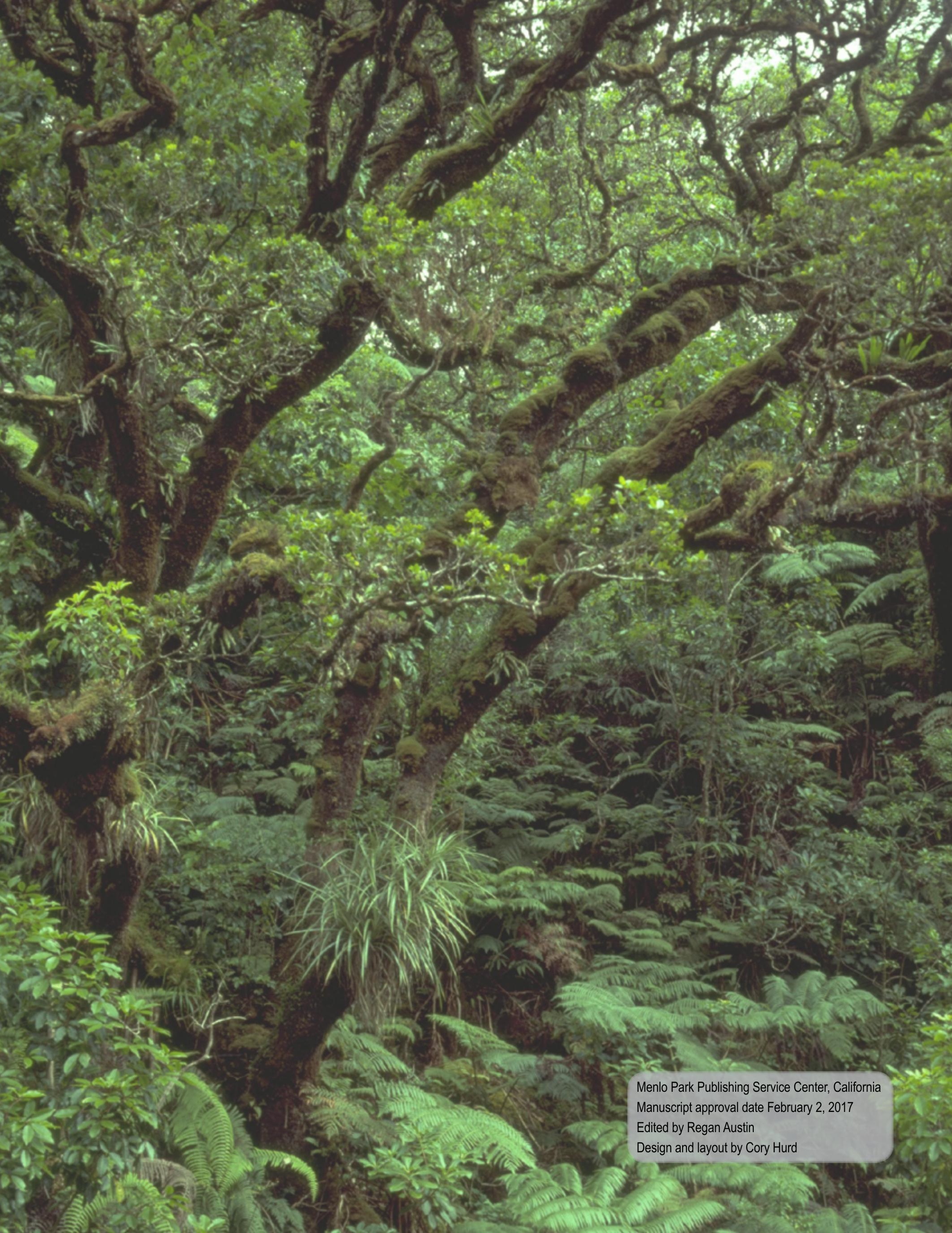




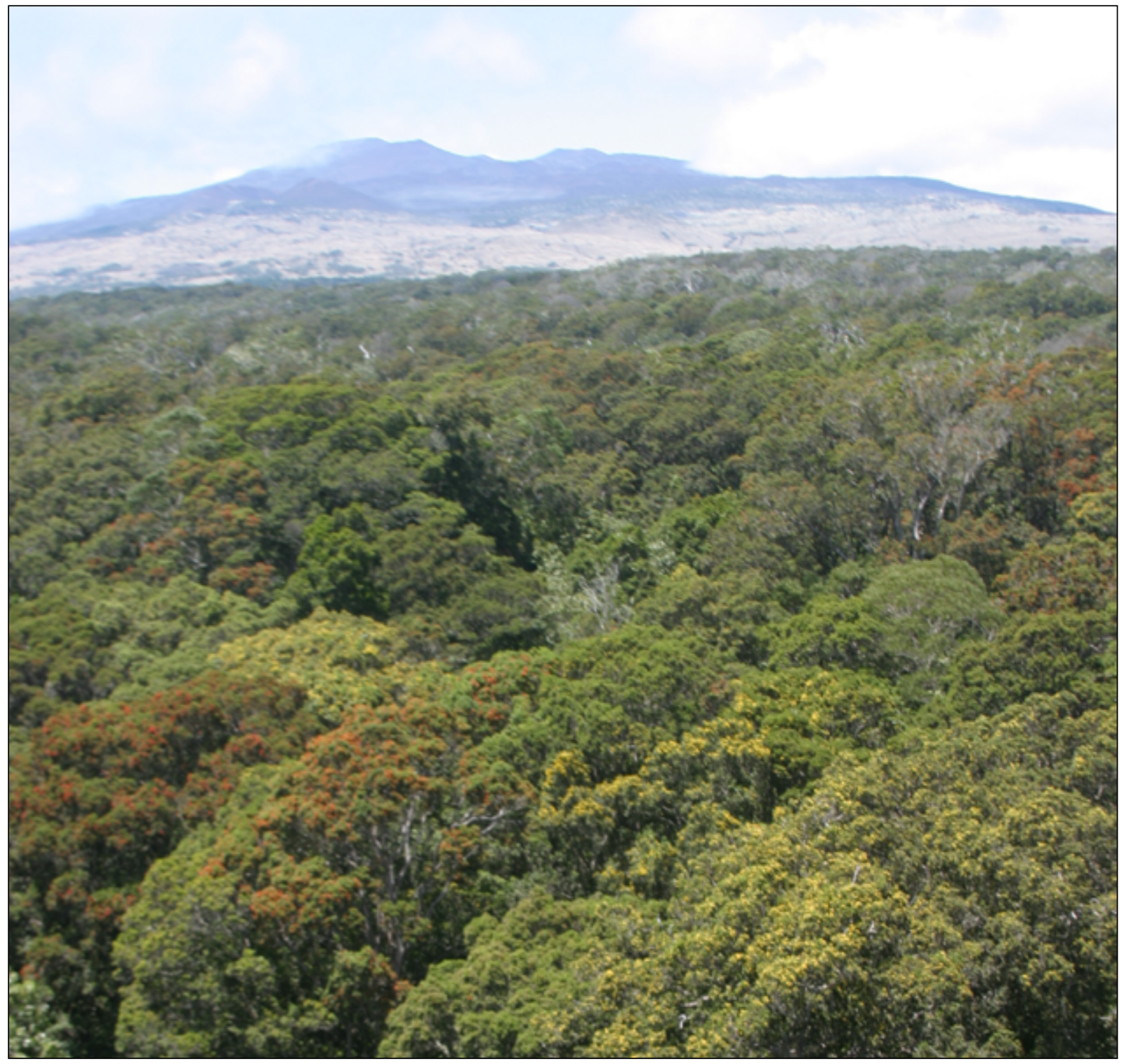

